\title{
Osoba i vjera u fenomenologiji religije Bernharda Weltea
}

\section{Maslać, Suzana}

Doctoral thesis / Disertacija

2021

Degree Grantor / Ustanova koja je dodijelila akademski / stručni stupanj: University of Zagreb, Faculty of Humanities and Social Sciences / Sveučilište u Zagrebu, Filozofski fakultet

https://doi.org/10.17234/diss.2021.8884

Permanent link / Trajna poveznica: https://urn.nsk.hr/urn:nbn:hr:131:981373

Rights / Prava: In copyright/Zaštićeno autorskim pravom.

Download date / Datum preuzimanja: 2023-04-26

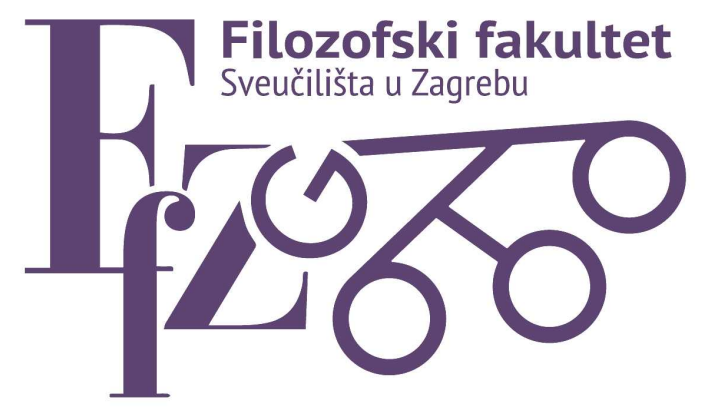

Repository / Repozitorij:

ODRAZ - open repository of the University of Zagreb Faculty of Humanities and Social Sciences
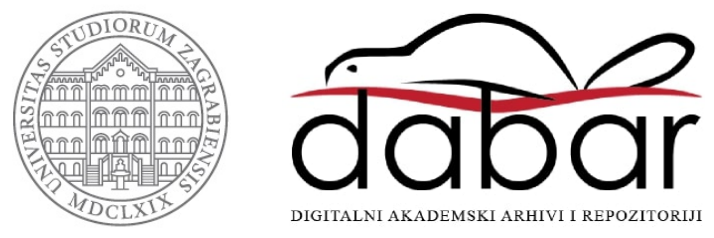


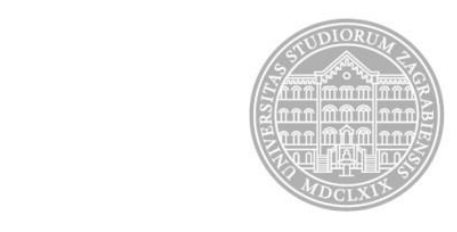

Sveučilište u Zagrebu

FILOZOFSKI FAKULTET

Suzana Maslać

\section{OSOBA I VJERA U FENOMENOLOGIJI RELIGIJE BERNHARDA WELTEA}

DOKTORSKI RAD

Zagreb, 2020. 


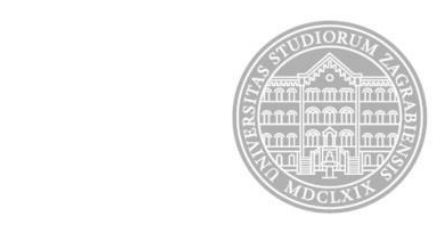

Sveučilište u Zagrebu

FILOZOFSKI FAKULTET

Suzana Maslać

\title{
OSOBA I VJERA U FENOMENOLOGIJI RELIGIJE BERNHARDA WELTEA
}

\author{
DOKTORSKI RAD
}

Mentor: izv. prof. dr. sc. Stjepan Radić

Zagreb, 2020. 


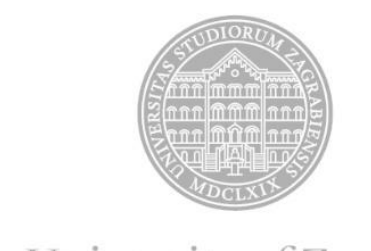

University of Zagreb

FACULTY OF HUMANITIES AND SOCIAL SCIENCES

Suzana Maslać

\title{
THE PERSON AND FAITH IN BERNHARD WELTE'S PHENOMENOLOGY OF RELIGION
}

\author{
DOCTORAL THESIS
}

Supervisor: Stjepan Radić, PhD, associate professor

Zagreb, 2020. 
Mentor: izv. prof. dr. sc. Stjepan Radić

Matični broj znanstvenika: 263041

\section{Curriculum vitae}

1975. rođen

1982. upisuje osnovnu školu

1990. završava osnovnu školu; upisuje Nadbiskupsku klasičnu gimnaziju s pravom javnosti u Zagrebu

1994. maturira na Nadbiskupskoj klasičnoj gimnaziji s pravom javnosti u Zagrebu; upisuje Filozofsko-teološki studij na Teologiji u Đakovu (danas KBF u Đakovu)

1999. diplomira na Teologiji u Đakovu; upisuje poslijediplomski studiji na Fakultetu filozofije i religijskih znanosti DI u Zagrebu

2002. magistrira (položivši licencijat i obranivši magistarski rad) iz područja filozofije na Fakultetu filozofije i religijskih znanosti DI u Zagrebu; mentor prof. dr. Ivan Koprek, tema Platon i grčka filozofija u djelu Karla Poppera 'Otvoreno društvo i njegovi neprijatelji' čime stječe titulu magistra znanosti (mr. sc.) iz područja filozofije

2002. upisuje Poslijediplomski doktorski studiji na Institutu za kršćansku filozofiju Teološkog fakulteta Sveučilišta Leopold-Franzens u Innsbrucku

2004. primljen u suradničko zvanje asistenta na Teologiji u Đakovu od kada predaje kolegije iz filozofije

2006. doktorira na Institutu za kršćansku filozofiju istoimenog fakulteta s temom Aktualität und Erneuerung der Tugendethik. Erörterung ihrer Ergänzungs- und Kulitivierungsperspektive (Aktualnost $i$ obnova etike vrlina. Razmatranje njene nadopunjujuće i kultivirajuće perspektive) kod prof. dr. sc. Edmunda Runggaldiera

2007. primljen u suradničko zvanje višeg asistenta na Katoličkom bogoslovnom fakultetu u Đakovu

2009/2010.; 2010/2011. drži kolegij Fenomenologija na Filozofskom fakultetu u Osijeku 
2011. izabran u znanstveno zvanje znanstvenog suradnika (znanstveno-nastavno zvanje docenta i radno mjesto docenta na KBF-u u Đakovu)

2012. počinje predavati na Doktorskoj školi Sveučilišta J. J. Strossmayera (do 2019.): na Doktorskom studiju Kulturologije izvodio kolegij Etika i istraživanje, a na doktorskom studiju Komunikologije suizvodio kolegij Etika javnog komuniciranja

2017. izabran u znanstveno zvanje višeg znanstvenog suradnika (znanstveno-nastavno zvanje izvanrednog profesora i radno mjesto izv. prof. na KBF-u u Đakovu)

\section{OBJAVLJENI ZNANSTVENI RADOVI}

\section{*Autorske knjige*}

RADIĆ, Stjepan, Die Rehabilitierung der Tugendethik in der zeitgenössischen Philosophie. Eine notwendige Ergänzung gegenwärtiger Theorie in der Ethik, Lit Verlag, Berlin, 2011. (str. 182); Knjiga.

\section{*Članci u a1/cc*}

RADIĆ, Stjepan, Neki od temelja moderne demokracije, u: Filozofska istraživanja 21 (2-3/2001), str. 495-513; pregledni rad

RADIĆ, Stjepan, Je li Platonovo poimanje pravednosti totalitarno, u: Filozofska istraživanja 92 (1/2004), str. 243-270; izvorni znanstveni rad

RADIĆ, Stjepan, Toleranz als Triebkraft von Demokratie und Menschenrechten: Eine Darstellung der Toleranz als Tugend, u: Synthesis Philosophica 46 (2/2008), str. 333-350; izvorni znanstveni rad

RADIĆ, Stjepan, Neki od problemskih aspekata 'Projekta svjetski etos'. Jedan analitičko-filozofski pristup problemu (I), u: Filozofska istraživanja 116 (4/2009), str. 733734; izvorni znanstveni rad

RADIĆ, Stjepan, Neki od problemskih aspekata 'Projekta svjetski etos'. Jedan analitičko-filozofski pristup problemu (II), u: Filozofska istraživanja 117-118 (1-2/2010), str. 269-282; izvorni znanstveni rad 
RADIĆ, Stjepan, Individualizam kao čovjekovo egzistencijalno uporište. Filozofskoteorijsko razmatranje individualizma s pripadajućim mu posljedicama, u: Bogoslovska smotra 81 (3/2011), str. 537-558; izvorni znanstveni rad

RADIĆ, Stjepan, Dva različita pristupa u rearistotelizaciji suvremene etike. Neoaristotelizam Alasdair MacIntyrea i Marthe Nussbaum, u: Filozofska istraživanja 33 (4/2013), str. 643-657; prethodno priopćenje

RADIĆ, Stjepan, Geneza Marxova ateizma - Pogled iz kuta Tome Verě̌a, u: Obnovljeni život 70 (4/2015), str. 457-471; izvorni znanstveni rad

RADIĆ, Stjepan, Laudato' si i pravednost. Pokušaj nacrta jedne socijalno-ekološke raspodjele dobara, u: Diacovensia 24 (1/2016), str. 45-64; izvorni znanstveni rad

RADIĆ, Stjepan, Ontološka dimenzija (moralnog) čina u svjetlu grijeha i krivnje, u: Diacovensia 27 (2/2019), str. 219-237; izvorni znanstveni rad

RADIĆ, Stjepan, Dijalektika radikalnog prosvjetiteljstva. Njegove mijene $i$ sjene $u$ tumačenju čovjeka i stvarnosti, u: Bogoslovska smotra, 90 (3/2020), str. 537-561; izvorni znanstveni rad

\section{*Članci u a2/c*}

RADIĆ, Stjepan, O nekim aspektima političke filozofije Nikolaja Berdjajeva i njenoj aktualnosti za suvremeno doba, u: Diacovensia 25 (1/2010), str. 65-92; izvorni znanstveni $\operatorname{rad}$

RADIĆ, Stjepan, Neki kontekstualno-ideološki aspekti Darwinove teorije evolucije s obzirom na njeno nastajanje $i$ promoviranje, u: Diacovensia 20 (1/2012), str. 75-91; pregledni rad

\section{*Članci u zbornicima*}

RADIĆ, Stjepan, O odnosu između aristotelovske $i$ tomističke etike kreposti kao paradigma odnosa filozofije i teologije, u: Pero Aračić (prir.), Teologija u dijalogu s drugim znanostima. Radovi znanstvenog simpozija s međunarodnim sudjelovanjem o 200. obljetnici filozofsko-teološkog studija u Đakovu, 1806.-2006., Đakovo, 2008., str. 117-138; izvorni znanstveni rad 
RADIĆ, Stjepan, Hagioterapija $i$ vrline. O nekim vidovima uloge vrlina $u$ hagioterapiji, u: Ž. Tanjić, T. Kovač, B. Murić, (ur.), Teologijom svjedočiti i naviještati, Zbornik radova u čast prof. dr. sc. Tomislavu Ivančiću, Kršćanska sadašnjost, Zagreb, 2010., str. 273-300; zbornik s međunarodnim sudjelovanjem

RADIĆ, Stjepan, Fenomen prijateljstva i pokušaj njegova sustavnog određenja, u: A. Gavrić i I. Šestak (ur.), Veritas vitae et doctrinae. U potrazi za istinom o čovjeku i Bogu. Zbornik u čast Hrvoja Lasića OP, Filozofsko-teološki institut DI, Zagreb, 2012., str. 96-111; zbornik s međunarodnim sudjelovanjem i međunarodnom recenzijom

RADIĆ, Stjepan, Osjećajnost i moralnost. Razmatranje ovog odnosa s obzirom na tri smjera: nekognitivizam, kognitivizam i etika vrlina, u: Anita Calvert, (ur.) Probudi Krepost. Aretaički pristup filozofiji, Filozofsko-teološki institut Družbe Isusove u Zagrebu, 2014, str. 103-130; zbornik s međunarodnim sudjelovanjem i međunarodnom recenzijom

RADIĆ, Stjepan, Kosmopolitismus und die Frage nach der Gerechtigkeit. Eine Auseinandersetzung mit der Rawl'schen Gerechtigkeitskonzeption aus kommunitaristischer Perspektive, u: H. Ottmann/P. Barišić, (ur.) Kosmopolitische Demokratie, Nomos Verlag, Baden-Baden, 2018., str. 149-163. zbornik na njemačkom jeziku, s međunarodnim sudjelovanjem i međunarodnom recenzijom. 


\section{Zahvale}

Veliku zahvalnost, u prvom redu, dugujem mentoru izv. prof. dr. sc. Stjepanu Radiću na mentorstvu i stručnom vodstvu tijekom doktorskog studija te nesebičnoj pomoći i savjetima prilikom izrade doktorskog rada.

Zahvalu upućujem i prof. dr. sc. Linu Veljaku koji me pratio od početka doktorskog studija i uvijek spremno odgovarao na moje mnogobrojne upite tijekom studija i završetka doktorskog rada.

Hvala mojim prijateljicama i kolegicama na poslu, Ankici Landeka i Lidiji Drmić, na podršci koju su mi iskazale tijekom studiranja. Naposljetku hvala mojim roditeljima, bratu i Moniki na podršci i razumijevanju koje su imali sve vrijeme mojeg studiranja i pisanja doktorskog rada. 


\section{Osoba i vjera u fenomenologiji religije Bernharda Weltea, Suzana Maslać}

U radu je obrađena tema Osoba $i$ vjera u fenomenologiji religije Bernharda Weltea (1906. - 1983.). Temeljni okvir, a koji je ujedno poslužio i kao podloga prvom dijelu rada, jest Welteovo djelo Gesammelte Schriften I/1 Person objavljeno 2006. godine. U cjelini o Osobi istog djela Welte predstavlja svoje viđenje ljudskog postojanja i fenomene koji su uz to postojanje vezani te slijedom toga iznosi originalni koncept ljudske osobe u cjelini. Taj je koncept na tragu aristotelovsko-kršćanske ideje o čovjeku, međutim Welte ovu sliku o čovjeku u bitnom obogaćuje i posuvremenjuje, pri čemu to obogaćenje ni po čemu ne odudara od netom navedene klasične ideje. To se obogaćenje sastoji u Welteovoj razradbi osobe $u$ kontekstu razgovora, jezika, kršćanstva i svijeta općenito, pri čemu čitavim izlaganjem dominira tema dijaloga. Nadalje se iznimno važnom pokazala tema odlučnosti i slobode još jednog istoimenog Welteova spisa Odlučnost $i$ sloboda iz 1966. godine gdje on promišlja o slobodi kao čovjekovoj duhovnoj kategoriji i uz nju vezanoj savjesti kao čovjekovu duhovnom putokazu prema dobru. Teme nade, straha i tjeskobe također su kod Weltea vezane uz ljudsko postojanje.

U konačnici ovaj filozof promišlja o ljudskom postojanju kroz prizmu igre i sreće. Sloboda je vezana u Weltea uvijek uz ljudsko postojanje i neodvojiva je od njegova bivstvovanja. U drugom dijelu rada krucijalno Welteovo djelo koje se obrađuje jest Filozofija religije koja je objavljena na hrvatskom jeziku 2016. godine. Welte ovdje promišlja o temeljnim pojmovima i stvarnostima vezanim uz pojam vjere i poglavito njezina izvršenja. $\mathrm{Na}$ samom početku drugog dijela riječ je o trenutku kada Welteova filozofija religije 1949. godine postaje fenomenologijom religije, pri čemu je dan svojevrsni uvod u fenomenološku filozofiju uopće. Srž drugog dijela, odnosno cjeline rada jest tema Boga kao začetnika religije te s njim čovjekova odgovora koji je sadržan u vjeri i njezinu izvršenju. Ovdje se također dotičemo i njemačkog mistika M. Eckharta koji je u svojim filozofsko-teološkim djelima predstavljao nadahnuće Bernhardu Welteu. Kao istinski filozof religije, Welte nije zaobišao ni njezine suprotnosti od kojih je ateizam najizraženiji. Stoga završne dijelove rada posvećujemo upravo ovoj temi, pokušavajući dati barem djelomičan odgovor na tako staro, ali i tako novo pitanje je li govor o Bogu i vjerovanje Njemu (još) uvijek moguć unatoč kaotičnosti i zlu koje je prisutno u svijetu. S Bernhardom Welteom smo zaključili da je to moguće. 
Ključne riječi: Bernhard Welte, Gesammelte Schriften 1/1 Person, Filozofija religije, osoba, vjera, fenomenologija religije, Bog, sloboda, odlučnost, vjera, molitva, M. Eckhart, ateizam 


\section{The Person and Faith in Bernhard Welte's Phenomenology of Religion, Suzana Maslać}

This disertation wishes to explore the topic of The Person and The Faith in Bernhard Welte's Phenomenology of Religion (1906-1983). The basic framework used as the basis for the first part of the paper is Welte's work Gesammelte Schriften I / 1 Person published in 2006. In Wlete's work in the part where he talks about the person, Welte presents his view of human existence and the phenomena associated with that existence, which consequently amount, to Welte's original concept of the human person, a person as a whole. Welte's concept is in line with the Aristotelian-Christian idea of man, and as Welte explores the classical idea of man as a person, he polishes the classical idea which philosophically speaking brings it up to date, enriching it by expanding it and making it more modern. The enrichment Welte brings consists in the dialogue in which one can elaborate the person in the context of Conversation, Language, Christianity, and The World.

In regard to the person the theme of determination and freedom proved to be extremely important, which is discussed in another of Welte's 1966 writings, entitled Determination and Freedom, where Welte reflects on freedom as man's spiritual category and with it associated conscience as man's spiritual compass towards good. With that, in Welte's philosophy the themes of hope, fear, and anxiety also relate to human existence. Ultimately, Welte contemplates human existence through the prism of games and happiness, where freedom is tied with human existence and is inseparable from man's existential situation.

In the second part of this disertation, Welte's crucial work Philosophy of Religion is examined, where Welte reflects on the concepts and realities related to faith especially those that relate to exercising faith. At the beginning of the second part, Welte's coining the term The Philosophy of Religion, being examined, as the term since he coined in 1949. later becomes known as the phenomenology of religion, which provides a good basis to introduce a philosophical- phenomenological of perspective of The Person and The Faith.

The core of the second part of this dissertation explores the theme of God as the originator of religion and Man as the one whose answer to God's call is contained in faith and its execution. In this part the philosophy of the German mystic M. Eckhart will be explored as his philosophical and theological works were an inspiration to Bernhard Welte. As a true philosopher of religion, Welte also examined atheism, in terms of religious expression, to which the last parts of this work will be dedicated to, in trying to give, at least in part, an 
answer to the phenomenon of atheism, and to the question whether talking about God and believing in Him is (still) possible despite the chaos and evil that is present in the world.

Keywords: Bernhard Welte, Philosophy of religion, Person, Religion, Phenomenology of Religion, God, Freedom, Determination, Faith, Prayer, M. Eckhart, Atheism 


\section{Sadržaj}

UVOD 1

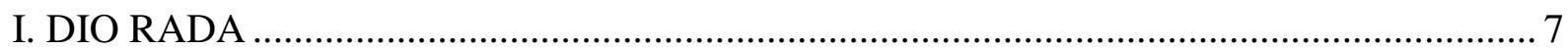

1. Uvodna razmatranja o Osobi u kontekstu Welteove fenomenologije religije .................. 7

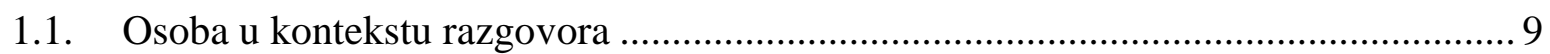

1.2. Daljnji izvodi Welteova odnosa osobe i razgovora: odgovornost i vještina ............. 11

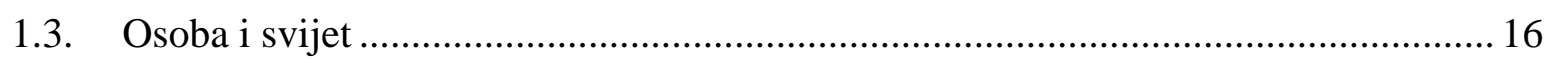

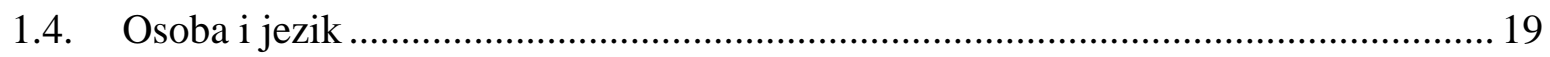

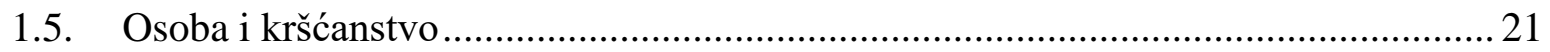

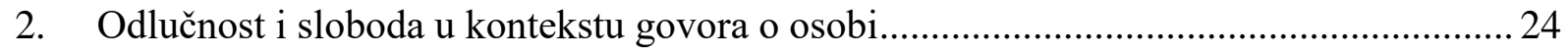

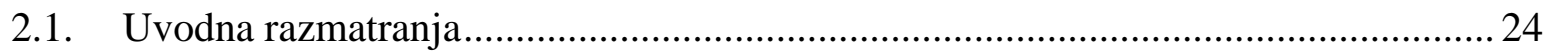

2.2. Savjest - čovjekov ,duhovni“ putokaz prema dobru ........................................... 26

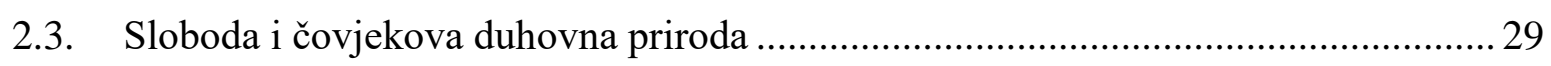

2.4. Ljudsko dostojanstvo u okviru Welteova govora o slobodi .................................... 31

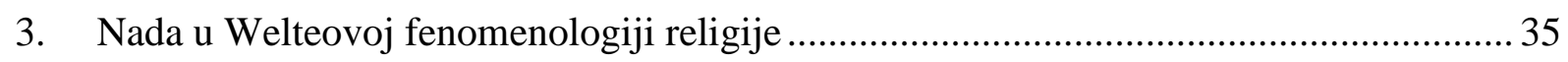

3.1. Fenomenologija nade i njezina važnost za ljudsko postojanje ................................ 35

4. »Strah« kao fenomen $u$ Welteovu promišljanju o osobi ............................................... 39

4.2. Smislenost čovjekova postojanja i strah - Welteova razradba straha ...................... 43

4.2.1. Pascalova oklada i Welteovo poimanje neizbježnosti u pogledu onoga s čim se

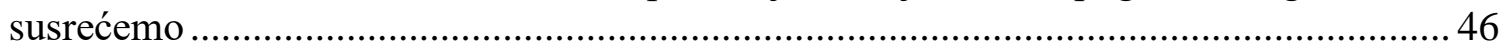

4.3. Tjeskoba kao sastavni dio straha: Welteova 'hrabrost za strah' ............................. 48

5. Ljudsko postojanje i igra kroz prizmu sreće .................................................................. 52

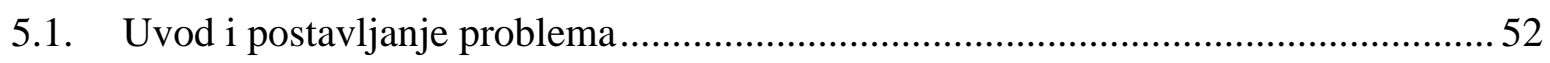

5.2. Pitanje i problematika igara na sreću............................................................. 53

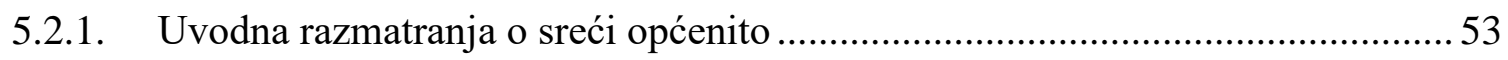

5.2.2. Igre na ,sreću“ i njihove posljedice za istinsku sreću ...................................... 55

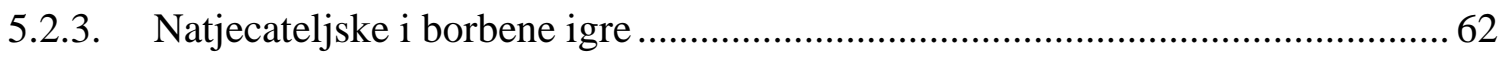

5.2.4. Regulacije i pravila u natjecateljskim igrama - dopuštanje doziranog i

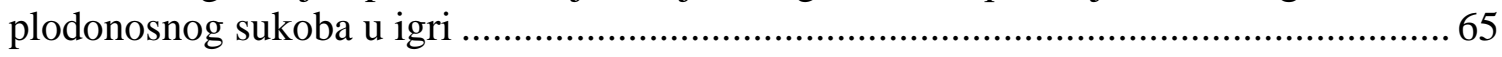

5.2.5. Borbena igra kao simbol života uopće: primjer nogomet ...............................69

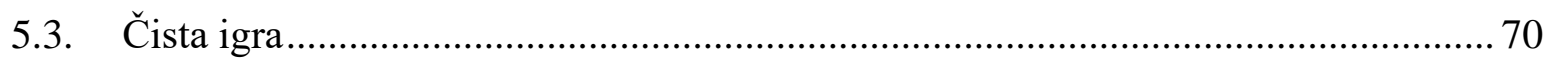

6. »Osvjetljavanje tubitka« u okviru Welteova promišljanja o osobi i njezinu postojanju.. 73

6.1. Uvod i pojam i problematika čovjekova postojanja .............................................. 73

6.2. Smislenost govora o ljudskoj osobi i tragovi transcendentnoga.............................. 76

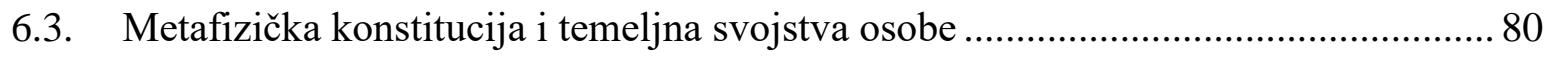

7. Sloboda i postojanje - temeljna polazišta i naglasci kod B. Weltea ................................ 84 
7.1. Uvodna razmatranja i postavljanje problema

7.2. Filozofijsko-teološke eksplikacije Welteova viđenja slobode i njezina daljnja

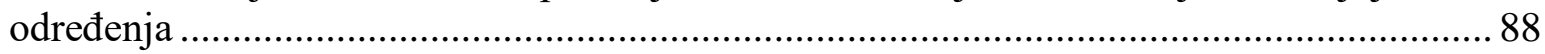

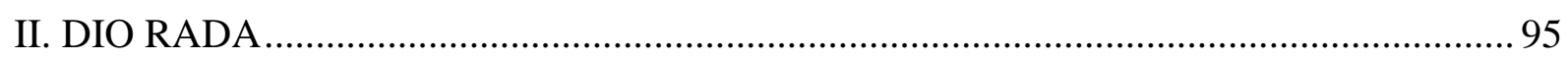

1. Fenomenologija i filozofija religije - sjecišta i razmeđa ............................................. 95

1.1. Općenito o metodi fenomenologije - Edmund Husserl kao začetnik ......................96

1.2. Husserl - ,povratak prema samim stvarima“ “...................................................... 98

1.3. O pojmu religije u Weltea - pretpojam i shvaćanje religije kao odnosa čovjeka

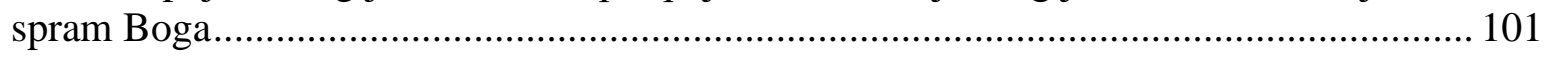

1.4. Welteova „filozofija“ $\mathrm{i}$ fenomenologija religije - temeljna ishodišta i izvodi ........ 105

1.5. Filozofija znanosti i religije u okviru Wittgensteinova Traktata .......................... 110

1.6. Filozofija znanosti Karla Poppera, kritički racionalizam Hansa Alberta i

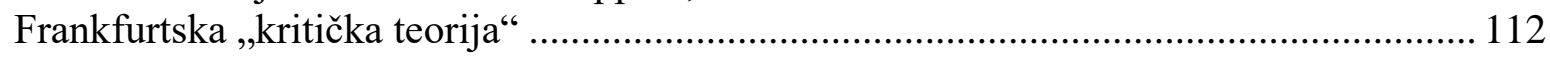

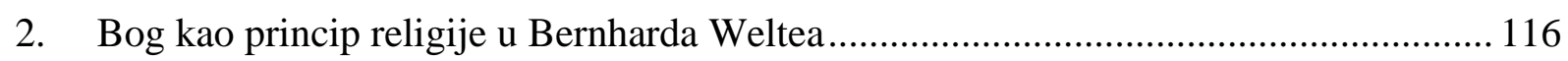

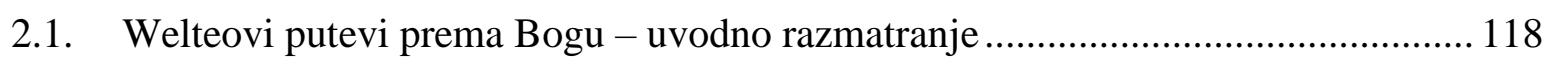

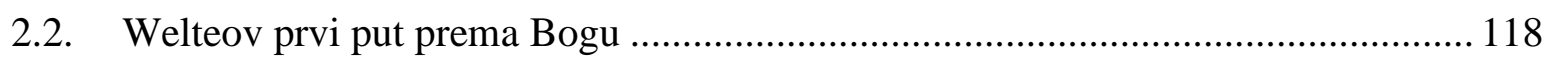

2.3. Welteov drugi put uzdizanja k Bogu .............................................................. 123

3. Važnost metafizičkih promišljanja Meister Eckahrta za fenomenologiju religije

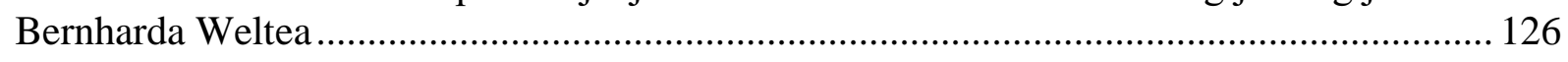

3.1. Pitanje o Bogu: Meister Eckhart i Bernhard Welte ............................................. 130

3.2. Zaključni izvodi o Eckhartovoj misli i Welteovu oslanjanju na njemačkog mistika 137

4. Pojam vjere u Welteovoj fenomenologiji religije

4.1. Molitva šutnje, govora i kulta kao načini izvršenja religije u filozofiji Bernharda

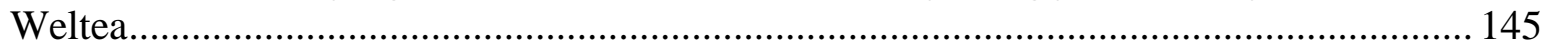

4.2. Oblici molitve i njihova važnost u Welteovoj filozofiji religije............................ 148

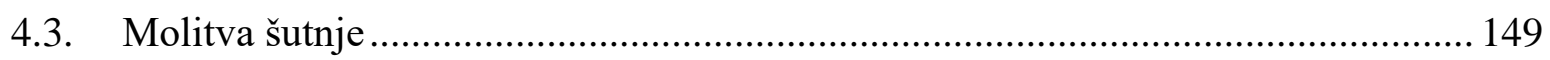

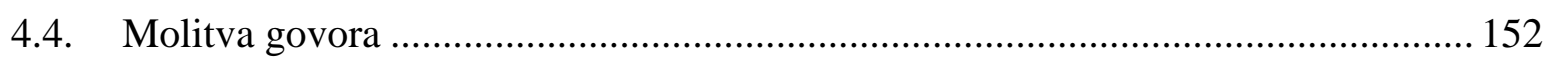

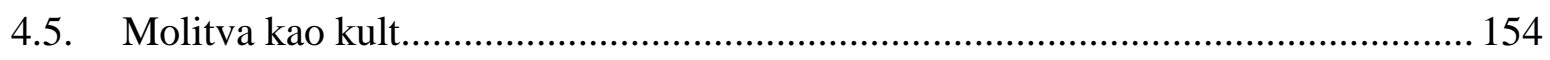

4.6. Prema zaključku: „Riječ“ i ,kult“ kao moguće opasnosti izopačenja religije ........ 156

5. Fenomen ateizma $u$ Welteovoj fenomenologiji religije ............................................. 158

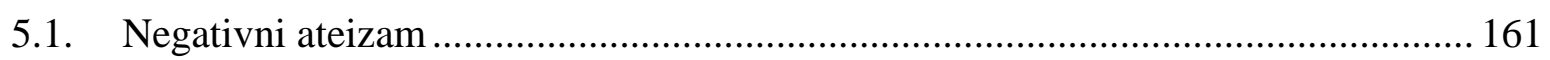

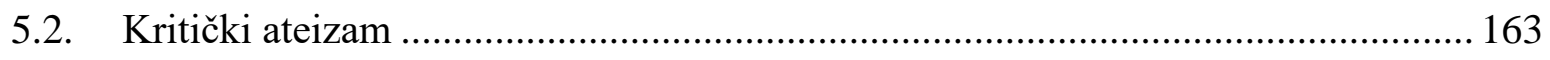

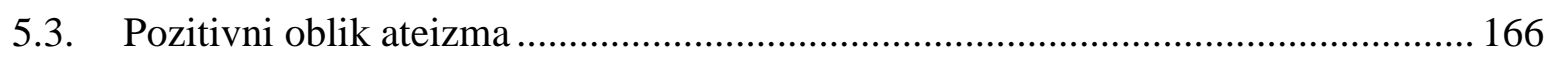

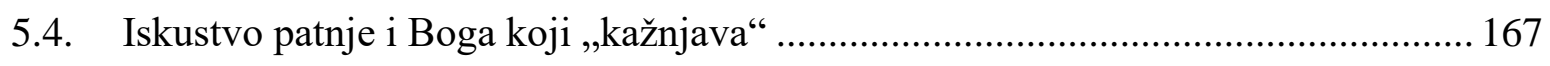

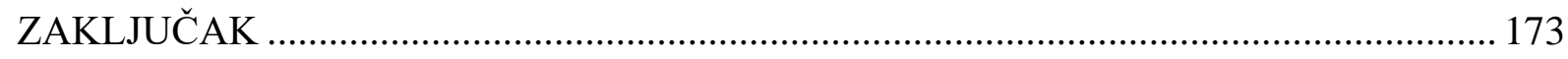

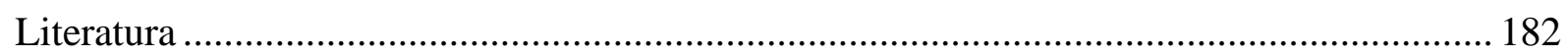

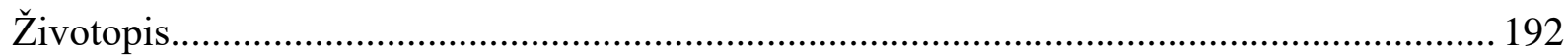

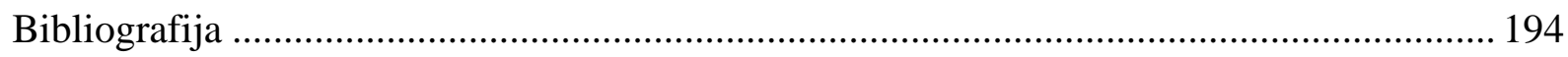





\section{UVOD}

Još je u vrijeme predsokratovaca, oslobađajući se od mita, filozofija religiju postavljala kao objekt proučavanja. Dotično je proučavanje išlo većinom u smjeru kritičkog propitivanja, kao i odlučnog razotkrivanja antropocentričnih i politeističkih oblika helenske religije, pri čemu je već tada postalo očito da filozofski pristup ima samo jedan autoritet onaj uma. Dotično je razdoblje - uzimajući, dakako, u obzir uz helensku također i cjelokupnu helenističku kulturu - pokazalo da se filozofski pristup religiji ne iscrpljuje tek u njezinoj kritici, odnosno prokazivanju u smislu nedosljednosti, kako u tumačenju same religije, tako i još više u njezinu izvršavanju. O filozofiji religije kao poddisciplini počinje se posebice govoriti od razdoblja njemačkog idealizma. Filozofija religije ne pita prvotno o Bogu, već o religijskoj svijesti. Primjerice u Hegela i njegovoj filozofiji religije postavlja se pitanje o tome je li i kako sama filozofija religija. Konačno filozofija i jest znanost koja proučava njezine 'prvotne uzroke i posljednje svrhe svih stvari' pa tako i religije. U toj sveobuhvatnosti pristupa te upravo zbog toga jednako bivaju važni i čovjek i Bog kao dva temeljna aspekta onog što nazivamo religija, odnosno izvršenje religije. Taj je sveobuhvatni pristup religiji, dakako uz osobitosti i izuzetke (primjerice srednjeg vijeka gdje su filozofija i teologija bile usko povezane), filozofija zadržala kroz čitavu povijest. Dvadeseto se pak stoljeće utoliko čini važnim što je na djelu upravo jedna renesansa filozofije religije, kao uostalom i filozofije jezika, duha, prirode i znanosti, pri čemu - važno je to napomenuti - u zadnjih tridesetak godina dominira upravo i specifično analitički pristup. ${ }^{1}$ Kada kažemo dominira, tada ne mislimo u apsolutnom smislu jer kontinentalna filozofija (pri tome mislimo prvotno na njemačko govorno područje) nudi klasični, filozofsko-teorijski pristup, što znači sveobuhvatni pristup religiji. Taj je pristup u poslijeratnoj Njemačkoj, istina, usko povezan s teologijom (konkretnije fundamentalnom teologijom), međutim on nije teološki, već u svojoj osnovi i strukturi specifično filozofski. Smatrajući da upravo taj pristup još uvijek sadrži originalnost te za filozofiju religije svojevrsni obnoviteljski potencijal, odlučili smo se u ovom doktorskom radu tu dimenziju proučiti, to jest istražiti s obzirom na jednog autora i (njegova) djela. Pothvat u koji se upuštamo ima za cilj predstaviti osnovne vidove fenomenologije i filozofije religije njemačkog filozofa i teologa Bernharda Weltea (1906. - 1983.) koji je prema mnogima jedan od najznačajnijih predstavnika filozofije religije.

\footnotetext{
${ }^{1}$ Značajnu studiju o tome na hrv. govornom području predočio je autor Danijel Tolvajčić. TOLVAJČIĆ D., Suvremena analitička filozofija religije. Glavni pravci i autori, Katolički bogoslovni fakultet u Zagrebu, Zagreb, 2016.
} 
$\mathrm{Na}$ samom početku treba reći kako je Welte bio učenik jednog od najznačajnijih filozofa 20. stoljeća, predstavnika filozofije egzistencije Martina Heideggera, te se uz njega iznimno mnogo oslanjao i na drugog značajnog filozofa istog stoljeća, Edmunda Husserla. Obojica su također pripadnici fenomenologijske filozofije koja će bitno utjecati i na neke Welteove fenomenologijske pozicije. Upravo ćemo iz te pozadine (kasnije) moći lakše razumijevati Welteov put u filozofsku misao koja počinje od spomenutih filozofa, ali koja je u bitnom obilježena biblijsko-kršćanskim misaonim sklopom te koju s obzirom na religiju on od 1949. naziva fenomenologijom religije. S tim u vezi nam se već ovdje postavlja pitanje što je to fenomenologija religije za Bernharda Weltea na što ćemo u određenim dijelovima rada pokušati dati potpuniji odgovor. Međutim, neka ovdje samo bude dopušteno istaknuti kako Welte na samom početku svojeg velikog, krucijalnog djela Filozofija religije kaže kako je fenomenologija religije ,iznašanje u pojavak svega onoga s čime se susrećemo“. ${ }^{2}$ Osnovna ideja i misao Welteove filozofije religije zapravo se dade iščitati već iz tumačenja samog pojma „fenomenologija religije“, a to je bilo nastojanje kako bi vjeru u okviru promišljanja o religiji učinio što više prihvatljivom i razumljivom. Upravo iz čovjekova življenja religioznog odnosa, kao i ostvarenja samog sebe, uzimajući na poseban način i subjektivnost onoga koji razmišlja, polazi Welteova filozofija religije kao ona koja prvotni temelj ima u čovjekovoj nutrini. Dotadašnji putevi koji su vodili k spoznaji Boga, prema Welteu, bili su vrlo nepristupačni i bilo ih je teško rekonstruirati. Za Weltea je temelj koji čovjek-vjernik kao hodočasnik traži Bog koji je živi Bog religija, Bog Abrahamov, Bog Izakov, Bog Jakovljev i Bog Isusa Krista koji živi među ljudima. U tome pronalazimo i pravi razlog zašto Welte toliko inzistira u svojoj misli krenuti od čovjekove nutrine, a da bi kasnije zaključio na ono naizvan. Da bismo shvatili to izvanjsko, kako ga nazivamo, potrebno je izaći iz proturječja i shvatiti prvotno ono „ništa“ (u Eckhartovu smislu) koje uzimamo kao sinonim za ono beskonačno ili bezuvjetno, imajući pri tome na umu zahtjevnost toga puta kako bismo pak mogli progovoriti nešto o naravi onoga zahvaljujući čemu imamo kakvo-takvo iskustvo. ${ }^{3}$ Upravo je to primjer koji susrećemo kod Weltea gdje on kaže kako čovjekova egzistencija biva ispunjena smislom i moguća jedino ako to „ništa“ nije neko prazno „ništa“, nego upravo ništavilo koje trenutno zakriva skrivenu prisutnost beskonačne i bezuvjetne moći koja čuva smisao svega i svemu udjeljuje smisao. ${ }^{4}$ Misli se, dakako, na samog Boga.

\footnotetext{
${ }^{2}$ WELTE B., Filozofija religije, prev. Kušar S., Matica hrvatska, Zagreb, 2016., str. 11.

${ }^{3}$ Usp. AGUTI A., Filozofija religije. Povijest, teme, problemi, KS, Zagreb, 2017., str. 182.

${ }^{4}$ WELTE B., Filozofija religije, str. 57.
} 
Welteova filozofska misao, iako je na tragu, ipak ne zarobljuje tradicijom Aristotela koja se usredotočuje na supstanciju kao ono bitno kod svakog bića te se u bitnom odlučuje za Husserlov i Heideggerov fenomenološki preokret koji pokušava razumjeti sve iz jednog izvornog odnosa čovjeka koji stoji nasuprot svijetu. ${ }^{5}$ Ovdje se važnim nameće spomenuti da postoje različite fenomenologijske tradicije koje su se javljale od Platona do Kanta kada je fenomen bio shvaćan kao pojava nečeg drugog (samog bitka), no u husserlijanskoj tradiciji (Husserl, Heidegger, Sartre, Hartmann itd.) pojava nije više razumijevana kao odraz nečeg drugog, već se pojavljuje na samoj sebi. To je bio i presudan obrat u povijesti fenomenologijske tradicije. Stoga ovo „iznašanje u pojavak“ govori u prilog tome da Welte slijedi klasično razumijevanje fenomenologije i fenomena. Situacija se dodatno komplicira u kršćanstvu jer je Isus istodobno tvarna pojava nečeg izvanjskog (Boga), ali je istodobno i Bog sam s obzirom na trojedinstvo Božje osobe, a Welte upravo polazi od pojma osobe u fenomenologijskom istraživanju. Kada kažemo da Welte slijedi husserlijansku tradiciju, tada svakako treba uzeti u obzir to da se ne radi o Husserlovu razumijevanju fenomenologije iz njegova dominantnog, ranog i srednjeg razdoblja, već kasnog razdoblja koje je utemeljeno na Krizi europskih znanosti i pokušaju prevladavanja iste pouzdavajući se u povijesno mišljenje.

Welteovo djelo Gesammelte Schriften I/1 Person, od kojeg polazi cjelokupna analiza ovog doktorskog rada kao i pripadajuća teza, plod je njegovih predavanja održanih od 1966. do 1978. godine na Teološkom fakultetu Sveučilištu u Freiburgu. Treba reći kako je Welte kršćanski mislilac, katolički svećenik, teolog i filozof. U spomenutom djelu ovaj freiburški filozof donosi najvažnije pojmove i religijsko-filozofske fenomene bitno vezane uz pojam osobe. Kroz cijeli Welteov opus posebno je istaknuta duhovno-umska komponenta osobe o kojoj promišlja. Jedino je osoba sposobna shvatiti i prihvatiti te se odlučiti za religiju, odnosno i konačno samu vjeru. Iz toga je razloga ključno bilo spomenuti Welteovo predavanje o Osobi iz 1966. godine u kojem iznosi misao kako je osobu uvijek potrebno promatrati u kontekstu susreta koji se događa u suživotu s drugim ljudima na temelju razgovora, jezika, svijeta. Jedino je osoba sposobna živjeti suživot s drugim ljudima, jedino se u osobi, ističe ovaj filozof religije, prepoznaje kako fizička, tako i duhovna komponenta njezina čovještva. Osoba se ostvaruje kroz živi susret $\mathrm{s}$ drugim i to ponajprije u razgovoru $\mathrm{s}$ drugim. Upravo se u razgovoru, to jest komunikaciji uopće očituje jedno ,ja“ koje ostvaruje konkretni susret s drugim kojeg Welte naziva „ti““. Pri tome čitavo kršćanstvo kao religija biva okvir u kojem se dotično odvija. Sve se ovo odvija u okviru ljudskog postojanja koje je prema

\footnotetext{
${ }^{5}$ Usp. HEIDEGGER M., Što je metafizika?, prev. Kordić I., Institut za filozofiju, Zagreb, 2015., str. 105.
} 
Welteu prožeto različitim fenomenima - primjerice nada, strah, tjeskoba, igra - kao izvanjskih očitovanja. Njima pak u pozadini leži, štoviše, kao svojevrsni izazov slobode i odlučnosti te odgovornosti koju osoba mora imati s konačnim ciljem koji se postiže u krilu Vječnoga, to jest božanskog osobnog Boga.

Pojam vjere u okviru Welteove fenomenologije religije, od kojeg polazi sveukupna analiza drugog dijela doktorskog rada, plod je njegovih predavanja o filozofiji religije održanih od 1962. do 1973. godine na Teološkom fakultetu Sveučilišta u Freiburgu. Do sada smo imali priliku vidjeti kako je metoda kojom se Welte služio prvenstveno fenomenološka. Spomenuta metoda predstavlja jedan način kako gledati sve ono bitno za religiju pa shodno tomu ista obuhvaća i teoriju i praksu, i um i djelovanje, i mišljenje i vjerovanje zajedno. ${ }^{6}$ Welteovi putevi prema Bogu polaze prvenstveno od presudnog pitanja o smislu. Kada se radi o pitanju smisla, svakako treba spomenuti Husserla i njegovo djelo Ideje gdje on u 3 . poglavlju Noesis/Noema pozicionira svijest kao ključnu odredbu fenomena (noematska struktura svijesti).

Put smisla pratimo i mi jer upravo u njemu baštinimo sve ono najbolje iz zapadnjačke tradicije mišljenja te svjesni vlastite odgovornosti, u welteovskom smislu, osluškujemo i odgovaramo Tajni koja nas se bezuvjetno tiče. Čovjekov odgovor Bogu pritom biva bitno dijaloški, ali sada u odnosu prema Bogu, kroz vjeru, molitvu i kult, što nadalje uočavamo kao presudno u namjeri podrobnijeg istraživanja dotičnih fenomena.

Drugi put spoznavanja, ili put koji vodi k Bogu, jest onaj koji se pita o temelju svega postojećeg. Koliko god nam ovdje znanost može donijeti odgovore na pojedina pitanja, ipak čovjek biva onaj koji je primoran izvršiti taj transcendentni skok, kako kaže Welte, skok u beskonačnu misao koja svemu daje svrhu i smisao, a koju predstavlja božanski Bog, koji sve utemeljuje, a pritom sam nije utemeljen. Welteovi putevi prema spoznaji Boga imaju svoj temelj u trećem putu Tome Akvinskoga koji on donosi u svojem djelu Summa theologiae ${ }^{7}$; i u tzv. Ontološkom dokazu sv. Anselma Canterburyjskog, točnije na temelju njegova djela Proslogion. ${ }^{8}$ Ovdje se ne radi tek i samo o klasičnom teološkom tumačenju Božjeg objaviteljskog principa (Pismo i sl.) već upravo o samom fenomenu religije koja, osim čovjekova dijalogiziranja s Bogom, i sama biva mjesto Njegova očitovanja. Dakle radi se o filozofski relevantnom području. Fenomenološki karakter Welteova pristupa ne svodi se samo

\footnotetext{
${ }^{6}$ KIENZLER K., Filozofija religije, predgovor, str. 11.

7 ARBANAS D., Kozmološki putovi Tome Akvinskog i Tillichovo poimanje kozmološkog tipa filozofije religije, u: Filozofska istraživanja = FI, 34 (2014) 1-2, str. 184.

${ }^{8}$ ĆUK B., Anselmov unum argumentum, u: Bogoslovska smotra = BS, 82 (2012) 1, str. 65.
} 
na činjenicu (izvanjske) religioznosti, već u bitnom i njezine takoreći unutrašnje dimenzije. Time smo došli u istraživanjima do pojma vjere i molitve koje su zapravo ključne dimenzije religije, bez kojih bi ona izgubila svaki smisao i autentičnost, a nerijetko postaje i izopačena jer puko izvršavanje bez unutarnjeg stava samo po sebi predstavlja svojevrsni gubitak smisla. Kada se stoga radi o filozofiji religije, ona se prema Welteu bavi religijom kao stvari ljudskog mišljenja, pri čemu on ističe i opasnost i korist filozofije religije za religiju. Unatoč tomu jedno je sigurno: kritička se refleksija religije pokazuje presudno važnom kod Weltea jer u suprotnom može doći do toga da se religija, kako on i sam navodi, „nereflektirano i nekontrolirano spusti na proizvoljnost, koja više ne odgovara njezinoj biti“.9

Treba reći i to kako filozofija religije kakvu Welte donosi nije ona koja stvara i izmišlja religiju, nego ju pretpostavlja kao ono što postoji u svijetu. Samo ju je potrebno osluškivati i pustiti da sama o sebi progovara. Ona je prvotno povezanost s Bogom. Iz ovog slijedi kako je Welteova filozofska misao prvenstveno vođena njegovim vlastitim iskustvom ili, heideggerijanski rečeno, 'faktičnim životnim iskustvom' - činjenica koja se pak prolama tijekom čitavog istraživanja. U djelu Zur Frage nach Gott opširno piše o iskustvu Boga koje imamo ili možemo imati i poziva svakog ponaosob na dublje promišljanje o istom, kako bismo upravo vlastito, a ne strogo nametnuto iskustvo Boga ozbiljno promislili i razumijevali. ${ }^{10}$ Faktično životno iskustvo o kojem je riječ, kao svojevrsno pounutrašnjenje religije, svoju posebnu dimenziju dobiva u molitvi, pri čemu se poseban naglasak stavlja upravo na nju kao condicio sine qua non čovjekove religioznosti uopće.

Vjeri, odnosno religiji, nasuprot stoji ateizam. Naš ga autor ne želi nipošto zaobići, već se s njim suočava $\mathrm{u}$ što ćemo se i mi upustiti pred kraj ovog istraživanja. On donosi promišljanja o pojavi ateizma dovodeći ga u vezu s pojmom humanog i općenito suvremenim sekularističkim tendencijama. Kada ističemo pojam humanog u kontekstu Welteova razmatranja ateizma, tada je važno naglasiti da mu Welte daje jedno teološko značenje što će reći da on nikako nije pridržan pravcima suprotnim religiji i onom teološkom općenito. Uvijek postoji ta iskra - božanski Bog - koja vodi religiju i uvijek se iznova može rasplamsati unutar pojedinca, zajednice, ljudi općenito. U tom smislu možemo na tragu Welteovih promišljanja istaknuti kako je religija neuništiva, pa čak i onda kada se čini da je kroz ateizam potpuno nestala - ona se uvijek i iznova vraća i može se vratiti. Možemo se stoga složiti i sa S. Zimmermannom koji u svojem djelu Filozofija $i$ religija govori o nerazdruživoj

\footnotetext{
${ }^{9}$ WELTE B., Filozofija religije, str. 35.

${ }^{10}$ Usp. WELTE B., Gesammelte Schriften III/3, Zur Frage nach Gott, ur. Zaborowski H., Herder Verlag, Freiburg, 2008., str. 50-70.
} 
povezanosti doživljaja moralne svijesti i religije: čovjek, naime, osim u pitanju smisla upravo kod (vlastite) moralnosti postavlja pitanje zašto biti moralan te (kantovski rečeno) postoji li neki krajnji princip, odnosno garant koji u konačnici i samoj moralnosti daje smisao. ${ }^{11}$ To samo potvrđuje Welteov stav kako religija nikada ne umire i biva moguća u svakom trenutku svakog pojedinog života jer opstoji i duh koji ju ponajprije izvršava ili, u općenitijem smislu, tek promišlja.

${ }^{11}$ Usp. ZIMMERMANN S., Filozofija i religija I-II, Zbor duh. mladeži zagrebačke, Zagreb, 1937., str. 353-354. 


\section{DIO RADA}

\section{Uvodna razmatranja o Osobi u kontekstu Welteove fenomenologije religije}

Predavanje iz 1966. Welte naziva Die Person als das Un-begreifliche (Osoba kao nerazumljivo) $)^{12}$ i početak je njegova dugogodišnjeg promišljanja o osobi kao takvoj, pri čemu samo pitanje uvjeta opstojnosti osobe dolazi u prvi plan. Odmah se na početku tih promišljanja dade zamijetiti jedan fenomenološki put: Welte, naime, započinje od konkretnih osoba koje susrećemo u svakodnevici koje, po njegovim riječima, nazivamo, odnosno označavamo jednostavnim pojmom ljudi. U pozadini pak svih promišljanja o osobi stoji temeljno pitanje što je čovjek. Postavljajući pitanje s izričajem što, a ne tko je čovjek, on je nastojao ukazati na nakanu objektivnog sagledavanja čovjekove osobnosti, odnosno njegova bivanja. Čovjeka se tako postavlja objektom spoznavanja, kao što je to slučaj sa svim drugim bićima u svijetu. Kada Welte postavlja ovo pitanje tko je čovjek, on želi ukazati na važnost izvjesne personalizacije osobnosti koja se ni na koji način ne da objektivizirati. Naime, on napušta skolastički princip quidditas i okreće se personalizaciji osobnosti i razumijevanju osobe prvotno kao duhovno umske i promatra ju u okviru susreta s drugim. Međutim, Welte u isto vrijeme zaključuje da pitanje što je čovjek, koliko god krajnje objektivizirano, ipak ostaje nedostatno te se svakako nužno mora nadopuniti u tko je čovjek. Iz pitanja tko je čovjek, odnosno osoba, proizlazi zapravo pitanje „tko si ti?““, „tko je ta određena osoba?““. Od samog početka razmišljanja Welte iznimno naglašava kako je taj pojam osoba izvan svih mogućih objektiviziranja i objektivizacija uopće. Osobu nije moguće tako razumijevati. Ona prkosi svim pokušajima ove vrste. Ono što se podrazumijeva pod pojmom osoba, u njezinoj odlučujućoj bîti, ne može dakle biti teoretski ili praktično objektivizirano, već je potrebno prekoračiti granice moguće objektivizacije. Osoba je uvijek u dijalogu s drugom osobom i tek se tako može tumačiti njezina sveukupnost - odnos prema drugome i prema svijetu u kojem se nalazi.

Ovako postavljeno pitanje - „tko si Ti?“, „tko je ova osoba?“ - preciznije cilja u smjeru u kojem se osoba i ono osobno (samo) može pokazati. ${ }^{13}$ Isto tako treba reći kako to nije neko općenito pitanje, nego konkretno, naime, tko je ta određena osoba?, pri čemu od ove konkretnosti dolazimo do izvjesne općenitosti. Welteovim riječima, nas ovdje zanima »osoba kao osoba« te što je to što označavamo kao ono „ljudsko“ u okviru promišljanja o osobi. ${ }^{14}$ Što

\footnotetext{
${ }^{12}$ Usp. WELTE B., Gesammelte Schriften I/1 Person, hg. Bohlen S., Herder, Freiburg, 2006., str. 96-139.

${ }^{13}$ Upućujemo ovdje na fenomenološki put na kojem ja Welte participirao.

${ }^{14}$ Usp. Isto, str. 96-139.
} 
se tiče pojma „ljudsko“, on kod Weltea ima ukazati na nepovredivu supstanciju koju osoba posjeduje, a to je njezino dostojanstvo i nepovredivost, što se pak dade povezati s onim svetim u čovjeku. U tome smislu logička posljedica ovog određenja osobe jest njezina duhovna dimenzija, pri čemu se pojam duhovno ovdje uzima u najširem ne strogo religijskom značenju. Upravo nam tu pomaže logos koja u svojem izvornom značenju zrcali temeljne karakteristike same osobe - riječ, misao, smisao. Pojam definicije ovdje ne smije zavarati u smislu nužnog ograničenja i svojevrsnog predodređenja osobe u pojmovnom i svakom drugom smislu. Jer kada se radi o nakani što točnijeg određivanja, to jest definiranja osobe, tada se vrlo često, s pravom, koriste negativni izričaji - kako to ističe Welte - naime, da je osoba nedodirljiva, nerazumljiva, nezamisliva, neodređena. Via negationis - što je iznimno zastupljeno u skolastičkom govoru o Bogu i ovdje upravo želi ukazati na važnost i dostojanstvo ljudske osobe. Što se pak tiče afirmativnog karaktera u pokušaju određenja, to jest definiranja ljudske osobe, najuniverzalnija i raširena postavka je ta da je osoba razumsko biće koje promišlja i slobodno biće koje djeluje na temelju vlastitih uvjerenja, pri čemu možemo ustvrditi da je to najkraća, međutim, i najtočnija definicija. Osoba dakle posjeduje unutarnju refleksiju po kojoj se razlikuje od svih drugih živih bića, s kojom (refleksijom) donosi prosudbe i slobodno djeluje. Stoga pridijevanjem negativnih epiteta osobi, na koje smo netom ukazali, ta osoba samo dobiva na važnosti jer ju izdiže ponad svih drugih živih nerazumskih bića.

Welte se poziva i na staru filozofsku tradiciju prilikom tumačenja osobe te pri tome posebno ističe filozofe Ebnera ${ }^{15}$, Rosenzweiga ${ }^{16}$, Bubera ${ }^{17}$ koji su uvelike pridonijeli u tumačenju pojma osobe, pokušavajući sagledati njezine temeljne aspkete koji bi ju

\footnotetext{
${ }^{15}$ Ferdinand Ebner, austrijski filozof (Bečko Novo Mjesto, 1882. - Gablitz, 1931.). Djelovao je kao učitelj u pučkim školama. Njegova teorija o odnosima ja-ti usmjerila je filozofiju Gabriela Marcela prema kršćanskom egzistencijalizmu. Na temelju teze jedinstva ja i ti u riječi razvio je religiozno usmjerenu jezičnu filozofiju, u: Proleksis Enciklopedija online, ur. Vujić A., Leksikografski zavod Miroslav Krleža, Zagreb. Pristupljeno 25. 8. 2020. Dostupno na: https://proleksis.lzmk.hr/19088/

${ }^{16}$ Franz Rosenzweig, njemački filozof židovskog podrijetla (Kasel, 1886. - Frankfurt na Majni, 1929.). Nastojao je filozofiju osloboditi svakog apriorizma. U duhu F. W. J. Schellinga polazio je od Božje neposrednosti u svijetu zbog čega čovjek, kako bi zaslužio otkupljenje, mora u bližnjem promatrati izvor i uvjet svojeg spasenja. Nasljedujući I. Kanta, Rosenzweig razlikuje univerzalne zakone i zapovijedi: dok univerzalni zakoni uređuju opći društveni i državni okvir, zapovijedi su neizravne praktične upute za društveni i državni život pojedinca. Utemeljio je Freie jüdische Lehrhaus, u: BROZOVIĆ D., KOVAČEC A., RAVLIĆ S., Hrvatska enciklopedija, mrežno izdanje, Leksikografski zavod Miroslav Krleža, Zagreb, 2020. Pristupljeno 25. 8. 2020. Dostupno na: https://www.enciklopedija.hr/natuknica.aspx?id=53382

${ }_{17}$ Martin Buber, židovski filozof (Beč, 1878. - Jeruzalem, 1965.). Profesor religiologije i etike na Sveučilištu u Frankfurtu na Majni (1924. - 1933.) te socijalne filozofije i sociologije na Hebrejskom sveučilištu u Jeruzalemu (1938. - 1951.); osnivač i urednik mjesečnika Der Jude (1916. - 1924.) i prvi predsjednik Izraelske akademije znanosti i umjetnosti. U svojoj se filozofiji uglavnom bavio političkom i duhovnom obnovom židovstva; utemeljio je tzv. filozofiju dijaloga (dijalogika) kojoj je u središtu odnosa Ja i Ti, čovjekov izravni odnos prema bližnjem, prema svijetu i prema Bogu, u: Isto. Pristupljeno 25. 8. 2020. Dostupno na: https://www.encklopedija.hr/Natuknica.aspx?ID=9904
} 
obuhvaćali. Na tragu određenja osobe kao razumskog bića, ona je za Weltea mnogo više od tek slučaja opće naravi ili općeg pojma. Na tom mjestu njemački filozof religije ne zaobilazi Boetia i njegovu nadaleko poznatu definiciju osobe koja je »individualna supstancija razumske naravi«. ${ }^{18}$ Ona ukazuje na to kako je osoba sasvim nešto drugo i drugačije od tek pukog pojedinačnog slučaja razumske individuacije prema njezinoj ontološkoj konstituciji te da bi tu definiciju svakako valjalo dodatno promisliti i proširiti kako ćemo, uostalom, u nastavku ovog rada i učiniti. Ono što je Welteu, međutim, već pri prvom pogledu ovdje zapelo za oko jest činjenica kako toj definiciji zapravo nedostaje vid postupanja ili, još jasnije, djelovanja, to jest čina kao takvih jer, iako je osoba razumske naravi, ona uvijek uključuje i neko nužno postupanje. Pojam postupanja Welte ovdje ne shvaća na banalan način - u vidu materijalizirajućih oblika rada i djelatnosti - već mnogo dublje. Ovdje se radi o najdubljim filozofskim osnovama čovjekova bića koje uključuju njezinu slobodu i dostojanstvo. To još jednom pokazuje kako se unutarnja živa i dinamična jezgra u osobi, Welteovim rječnikom rečeno, nalazi izvan izravnog pristupa bilo kakvog objektiviranja, bilo da je riječ samo o razmišljanju, opisnom razumijevanju ili nečem trećem. Welteovo ustezanje od pukog objektivnog kategoriziranja, i time spoznavanja ljudske osobe, daleko je od svakog spoznajnog relativizma, odnosno stava da pojam osobe potpuno izmiče racionalnom zahvatu. Kao istinski filozof, Welte želi jednostavno ukazati da osoba, baš zato što je duhovna-umska supstancija, $\mathrm{u}$ isto vrijeme posjeduje jednu dinamičnu strukturu, očitovanu primjerice po odnosima koje stvara. Iz toga je razloga za Weltea iznimno važan i vid susreta između osoba. Riječi koje izgovaramo prilikom susreta s drugim/drugom uvijek imaju određenu vrijednost $\mathrm{i}$ poruku. Jer ne možemo na osnovu izvanjskog promatranja određene osobe nešto sa sigurnošću zaključiti o istoj sve dok ne doživimo osobu u živom susretu.

Stoga u nastavku rada treba vidjeti kako to Welte tumači osobu u razgovoru kao određenoj vještini, nadalje osobu $\mathrm{s}$ obzirom na pripadnu joj odgovornost te kako funkcioniraju zajedno osoba i svijet te osoba i jezik. Konačno, navedeno će biti promotreno u kontekstu osobe i kršćanstva.

\subsection{Osoba u kontekstu razgovora}

Pojam razgovora Welte uzima kao iznimno važan u svojem promišljanju o osobi. Prema freiburškom filozofu, osobu valja u bitnom promatrati i u kontekstu (raz)govora.

\footnotetext{
${ }^{18}$ Usp. WELTE B., Gesammelte Schriften I/1 Person, str. 96.
} 
Osoba se kroz razgovor povlači i time oslobađa iz svih objektivizirajućih pristupa i dovršenih, to jest končanih rješenja. Naime, upravo je u razgovoru (kao, uostalom, u misli koja ovom prethodi) suočena s uvijek nečim novim. Taj je susret nužno slobodan. Susret između »ja« i »ti« uvijek donosi sa sobom jednu neusporedivost sa svime što se dogodilo prije i jedinstvenost jer se uvijek događa nešto novo. ${ }^{19}$ Upravo u ovom susretu postaje očito kako nismo tek puki slučaj, već jedinstveni kao osobe, ,ja“ i „ti“. Na ovom se mjestu Welte poziva na Kierkegaarda i ističe kako osobe u susretu bivaju pojedinci na visokoj razini promišljanja i s polemičkim patosom koji se događa kroz razgovor (zanos, oduševljenje i ushićenje). ${ }^{20}$ Kako postati samim sobom, »jedan jedini«, odnosno »individua«, pitanje je koje Kierkegaard stavlja u središte svog filozofskog interesa. Put od običnog opstanka do zbiljskog egzistiranja, odnosno od »gomile« do »individue«, ostvaruje se, kako je i poznato, kroz tri stadija: estetski, etički i religiozni. ${ }^{21}$ Pojam individuacije, koju smo kod Kierkegaarda kratko dotaknuli, igra i kod Weltea važnu ulogu u tumačenju osobe, pri čemu filozof iz Freiburga iznimno pazi na to da taj pojam ne apsolutizira, kako će to biti slučaj s mnogim suvremenim pravcima filozofije života te općenito teorijama liberalne misli. Da bi u tome uspio, poseže za vrelima biblijskokršćanske misli, uvodeći u koncepciju tumačenja osobe kao individue stvarnost onog drugog, „ti““. Welte je mišljenja kako osobe u susretu ,ja“ i ,ti“ ostaju uvijek apsolutno individualne te istovremeno ne-individualne, paradoks koji upravo u razgovoru izmiče protuslovlju. Uvijek postojimo apsolutno odvojeno, prepoznajemo tko smo mi, a tko je druga osoba s kojom smo u komunikaciji i susretu. Svatko je od nas usredotočen na sebe u smislu jedinstvenosti osobnog koja se još jednom potvrđuje u individualnosti osobe. Međutim, ta odvojenost nije radikalne prirode, poput one u životinjskom svijetu. U susretu s drugom osobom s kojom razgovaramo događa se to da upoznajemo, gledamo, zovemo, dobijemo odgovor na određeno pitanje ili konstataciju i tako se odvija susret kroz razgovor, pri čemu su za tu stvarnost razgovora potrebe izvjesne vještine o kojima će u daljnjim dijelovima biti svakako riječi. Prije njih, međutim, Welte u igru uvlači moralno-etički moment odgovornosti.

Prihvaćajući sudbinu susreta, odgovoran sam. U odgovornosti za susret prvo doživljavam ono što se ne može shvatiti ni u jednom općem pojmu: ono Ti! U takvom susretu , ja“ i ,ti“", mi smo mjesto otkrivenja, otkrivenja onog što se riječima izreklo. ${ }^{22}$ Welte će u tom smislu odlučno ustvrditi: ono što se događa u susretu, to samo događanje zrcali na određeni

\footnotetext{
${ }^{19}$ Usp. Isto, str. 97-98.

${ }^{20}$ Usp. Isto, str. 97-98.

${ }^{21}$ Usp. BULJAN I., Problem postajanja pojedincem u djelu Sørena Kierkegaarda, u: FI, 28 (2008) 2, str. 277 302.

${ }^{22}$ Usp. WELTE B., Gesammelte Schriften I/1 Person, str. 109.
} 
način pojam osobe. ${ }^{23}$ Stoga ono što se da zaključiti iz Welteova predavanja jest kako »ja« $\mathrm{i}$ »ti« uvijek pripadamo živom suživotu događaja susreta. Iz zajedništva i u njemu ja i ti se međusobno upoznajemo i učimo živjeti sâmo zajedništvo. Osobe uče jedna o drugoj uvijek nešto novo, a to zajedništvo u kojem i koje žive početak je odgovornosti za taj susret i suživot uopće. Važno je ukazati na to da (pravo) zajedništvo, ma kako intimno bilo, nikako ne dokida individualnost. $U$ tom će smislu Welte reći znakovito da što je pojedinac više individua, to je $\mathrm{i}$ veće zajedništvo, a tko ima nešto originalno za reći, može originalno i odgovoriti. Iz toga se vidi kako su pojmovi osobe i osobnog vrlo široki i ne mogu se objasniti na način strogih tehničkih definicija, već osluškivanjem, pri čemu se upravo unutar zajednice, osluškivanjem, slušanjem „osobljujemo“ - postajemo više osobe. Također, osobito u zajednici (bilo koje vrste), osoba dobiva na vrijednosti i svojoj osobnosti.

\subsection{Daljnji izvodi Welteova odnosa osobe i razgovora: odgovornost i vještina}

Spomenute karakterizacije osobe kroz vid razgovora, odgovornosti i vještine zahtijevaju iscrpniju analizu koju ćemo u nastavku ovog poglavlja i prikazati. ${ }^{24} \mathrm{Kroz}$ poznatu dimenziju da je osoba razumsko biće, misli o osobi i osobnom odnosu bivaju prožete živom strukturom onog što smo oduvijek bili: svatko za sebe, a opet svi zajedno. To bi pak dalje značilo da svaka osoba poznaje i priznaje svoju vlastitu individualnost, zna da je pojedinac za sebe, razlikuje se od drugih pojedinaca s kojima živi i postoji.

U kontaktu i susretu s drugom osobom bivamo svjesni kako smo uvijek pojedinačno biće, svatko od nas bivstvuje na jednak način i odgovor na poticaj drugog s kojim smo u komunikaciji i zajedništvu označen je, Welteovim riječima, kao dijalektika igre. Uvijek smo svjesni svog jastva ${ }^{25}$, prepoznajemo sebe kao onu osobu koja je ,ja“, drugu osobu koja je „ti“

\footnotetext{
${ }^{23}$ Usp. Isto, str. 110.

${ }^{24}$ Usp. Isto, str. 111.

${ }^{25}$ Tragom navedenog djela objašnjenje možemo dodatno produbiti. Kada se, naime, radi o poimanju »ja«, treba reći kako je to filozofski i psihološki pojam. Osnovno značenje odnosi se na svaki odjelit individualan identitet neke ljudske prirodne osobe pa u tom smislu upućuje na sebstvo. U zapadnoj filozofiji javio se prilično kasno, to jest gotovo je nepoznat antičkoj i srednjovjekovnoj filozofiji čija su istraživanja poglavito usmjerena na odnos duše i tijela, iako ne bi valjalo zanemariti relevantnost delfijskog proročanstva Spoznaj samog sebe! (što je posebice bitno utjecalo na Sokrata koji filozofski tematizira smisao tog imperativa), kao ni činjenicu da se kod A. Augustina nazire filozofsko tematiziranje tog pojma. Izdiferenciran pojam »ja« dao je u sasvim jednoznačnom smislu R. Descartes, i to posredstvom dvaju svojih stajališta: »ego sum, ego existo« (ja jesam, ja postojim) i »cogito, ergo sum« (mislim, dakle jesam), gdje se ističe dvostruki karakter »ja«: ono je egzistirajuće, ali samo kao misleće biće (res cogitans). Za J. Lockea »ja« je biće koje svjesno misli, dok D. Hume na tragu G. Berkeleya svodi »ja« na snop predodžbi. U smislu koji će biti odlučujući za svu potonju filozofiju I. Kant razlikuje empirijsko »ja« (phainomenon) i transcendentalno »ja« (noumenon). Dok je empirijsko »ja« pojava poput svakog drugog predmeta te zato objekt izvanjskog osjetila, transcendentalno se $» j a \ll$, kao jedinstvo svijesti
} 
i koja je neophodna kako bi se odigrala ova dijalektička igra. ${ }^{26} \mathrm{U}$ toj igri postajem svjestan svoga ja, onog što jesam pred onim drugim bićem s kojim sam u kontaktu susreta. Ova osobna dijalektika igre prolazi kroz nekoliko stupnjeva razvoja.

Prvi od tih stupnjeva započinje još u njedrima obitelji. U ovom okruženju i krugu događa se sam početak razvoja osobe. Događa se određeno buđenje, osoba prolazi kroz različite uspone i padove. Riječ je o zajedništvu susreta u kojem je na djelu pojedinačno buđenje, a koje se ujedinilo u zajedništvu obitelji. U ovoj je fazi djetetovih početaka dijalektika prepoznata i nošena samim tijekom prirode u kojoj dijete pomalo postaje sposobno razlikovati sebe od drugih osoba. Doživljava se, za individuu od prijeke važnosti, odijeljenom od drugih. ${ }^{27}$ Dakle konkretnije postaje svjesno svojeg ,ja“ koje se nalazi nasuprot roditeljskom „ti“. U drugoj fazi ove dijalektike susreta događa se prepoznavanje i razlikovanje mojeg ,ja“ od tvojeg ,ti“. U ovoj fazi osoba postaje konkretno ja, biva sposobna spoznati na jedan svjesniji način, kako sebe samog, tako i drugog s kojim živi. Na ovom se mjestu događa i napetost između mojeg, ,ja“ spram tvojeg „,ti“ ${ }^{28}$

Poanta, to jest specifičnost ove pozicije, u odnosu na netom spomenutu prvu, jest ta da odijeljenost predstavlja uvjet za svijest o sebi. To je zapravo drugi vid ovog odjeljivanja, izolacije, u kojem osoba postupno postaje svjesna same sebe, svojeg jastva. Upravo zato i

ili apercepcije, spoznaje samo unutarnjim osjetilom, to jest mišljenjem. Tako on u Kritici čistog uma naglašava: »Ja sam kao misleći predmet unutarnjeg osjetila i zovem se duša. Ono što je predmetom izvanjskog osjetila zove se tijelo«. Pojam »ja« zadobiva središnju važnost u Fichteovoj filozofiji. Držeći da se cjelokupna zbiljnost ima izvesti iz samosvjesnog subjekta, on taj pojam imenuje terminom Ja. Ja je prvi i apsolutni princip svega što jest, a njegova se bit sastoji u identitetu subjekta i objekta. Svoj nauk o Ja on razvija u tri osnovne postavke: Ja jesam; $J a$ postavlja ne-Ja kako bi uspostavilo sebe; $J a$ stavlja u samom $J a$, nasuprot djelomičnom $J a$, djelomično ne-Ja. Time $J a$ sebe ograničava u svojoj beskrajnoj i apsolutnoj aktivnosti kako bi praktičko $J a$ postalo apsolutno slobodnim. U XIX. je stoljeću došlo do vrlo bogatog diferenciranja tog pojma. Ja je izvorno trebao biti naslov glavnog djela M. Stirnera koje je konačno objavljeno pod naslovom Jedini i njegovo vlasništvo (1844), ali je drugo poglavlje te knjige ipak tako naslovljeno; Stirner tu sebe određuje kao »filozofa ja« i uvjeren je da je on utemeljitelj nove filozofije ja. Dominantne koncepcije u akademskoj filozofiji XIX. st. vezane su, međutim, uz tzv. psihologizam: redukcionistički pojam svodi »ja« na psihička stanja ili činjenice, intelektualistički, što ga zastupa J. F. Herbart, polazi od toga da, nasuprot Kantu i njegovu dobu, postoji samo empirijsko »ja«, nositelj kojeg su predodžbe na koje se ono kao jedinstvo ne može raspasti. Senzualističko razumijevanje »ja« polazi od osjeta kao nositelja »ja« koji uvjetuju sve strukturne promjene njegova identiteta (E. Mach). Voluntaristički pojam »ja«, pod utjecajem A. Schopenhauera, uzima volju kao nositelja »ja« (W. Wundt) jer samo stalnost htijenja može sačuvati njegov identitet; u tom smislu F. E. Beneke svodi »ja« na snop nagona, snaga i moći. Nasuprot tomu emocionalistički shvaćeno »ja« postiže svoj identitet tek zahvaljujući tome što u sebi, putem osjećaja, sadrži i ono osjećajno, pa svijest nije ništa drugo do samoosjećaj (T. Lipps). Prema Lippsu se u unutarnjoj uživljavajućoj djelatnosti »ja« krije osnova svakog umjetničkog stvaralaštva. Sve te koncepcije svojstvene XIX. st. općenito se mogu definirati kao psihologističke. Psihologističke teorije »ja« pretrpjele su žestoke kritike u filozofiji na početku XX. st., posebice kod E. Husserla koji upozorava na to da se psihologizam temelji na neosviještenim predrasudama i da nužno završava u empirizmu, relativizmu i skepticizmu, Veljak, L., Sunajko G.: u: FILOZOFSKI LEKSIKON, ur. Kutleša S., Leksikografski zavod Miroslav Krleža, Zagreb, 2012. str. 550-551.

${ }^{26}$ Usp. WELTE B., Gesammelte Schriften I/1 Person, str. 111.

${ }^{27}$ Usp. Isto, str. 111-112.

${ }^{28}$ Usp. Isto, str. 112. 
psihologija govori o presudnom razdoblju sedme godine života. Ova opozicija spram drugog pomaže osobi da shvati i spozna sebe samu, međutim u isto vrijeme i drugog do sebe. Napetost koja se događa kroz ovu drugu fazu nije nužno negativna, nego upravo tako osoba uviđa kako ima svoj vlastiti put spoznavanja i djelovanja koji je drugačiji od puta, to jest načina osobe s kojom komunicira i eventualno živi. Osoba postaje svjesna svoje pojedinačnosti u kojoj se da iščitati ono ,ja“ nasuprot „ti““. To je tijek prirode koji se ne može mijenjati i faza kroz koju svaka osoba mora proći na putu samorazumijevanja i sazrijevanja. I u ovom stupnju ,ja“ i ,ti“ idu zajedno kroz životne faze, no u ovoj se fazi događa kako izoliranost, tako i susret pa cijela dijalektika susreta i igre poprima jedan novi ton, a time i novu oštrinu i izražajnost. ${ }^{29}$

Dijalektiku susreta kakvu nalazimo u Weltea možemo svakako povezati s Buberovom filozofijom dijaloga koja je utemeljena na dijaloškom načelu ,ja-ti“. Welteova razradba fenomenologijskog načela odnosa ,ja-ti“ nema nakanu pukog iščitavanja onog što (ionako) primjećujemo u svakodnevici: ljudi se povezuju na mnogostruke i različite načine stvarajući pri tome odnose. Ovdje se radi, kako je to za Weltea sada već uobičajeno, o nečem mnogo dubljem: na djelu je dakle, s obzirom na odnos ,ja-ti“, unutarnja struktura same osobe. U dubini vlastitog bića mi opstojimo na razini odnosā: prvo prema samima sebi, a zatim i dalje. Slično je i kod Bubera: temelj tog dijaloškog načela ili dijalogike, prema Buberu, nalazi se u sferi »Između« koju on tematizira kroz dimenziju kako unutarnjeg, tako i vanjskog susretanja i dijalogiziranja. ${ }^{30}$ »Između« pronalazimo u susretu u čijem je središtu dijalog koji je utemeljen pak na jezičnom izrazu. ${ }^{31}$ Jezik daje susretu svojevrsnu izravnost. Izravnost odnosa o kojoj je riječ ne uspostavlja se samo kroz posredništvo osjetila i kroz puko bivanje sa živim bićima, nego i kroz posredništvo onih značenja koja proizlaze iz područja simboličke komunikacije, kao što su dakle već naznačeni jezik te dalje vrlo važni umjetnost, književnost itd. $^{32} \mathrm{O}$ umjetnosti i književnosti koja se ovdje sama po sebi nameće Welte toliko ne raspravlja, već se općenito zadržava na odnosu osobe i jezika, odnosno simboličkog izražavanja. ${ }^{33}$

Konkretni suživot s drugim osobama jest ono što se pokazalo vrlo bitnim za Weltea i njegovu dijalektiku susreta koja je zapravo mnogostruki dijalog između osoba koje sudjeluju

\footnotetext{
${ }^{29}$ Usp. Isto, str. 112-113.

${ }^{30}$ DODLEK I, Buberova filozofija dijaloga i umjetnost kao susret, u: FI, 33 (2013) 1, str. 83-95.

${ }^{31}$ Isto, str. 83-95.

${ }^{32}$ Isto, str. 83-95.

${ }^{33}$ Tema odnosa osobe i jezika čini važan aspekt Buberova razmatranja tako da ćemo u nastavku ovog rada svakako podrobnije razmotriti to područje.
} 
u susretu. Po načelu onog što dijalektika po sebi predstavlja u najuniverzalnijem i poznatijem tezu, antitezu i sintezu, dijalektika susreta u Welteovu smislu očituje svu ljepotu, ali i paradoksalnost zajedničkog života koji ovdje predstavlja treću fazu. Susret je u počecima redovito u fazi povezivanja, da bi iz nje prešao u fazu konfrontiranja gdje put dijalektike vodi dalje plodonosno zajedništvo ili rascjep. Da bi zajedništvo uspjelo, mora se dogoditi suprotstavljanje ,iznutra“. Ego, ,ja“, je onaj koji se javlja i počinje suprotstavljati onom prirodnom »ja«, i sve što je uz njega vezano u smislu parcijalnosti poput osjetilnosti, senzualnosti, da bi susretanje, odnosno zajedništvo s drugom osobom bilo omogućeno. Taj vid svojevrsnog izdizanja pruža, prema Welteu, dodatnu sposobnost uvida osobi o njoj samoj, njezinim karakteristikama, svojstvima itd., no isto tako i uvid u pogledu spoznavanja, odnosno prepoznavanja kakav je Onaj koji stoji nasuprot. Suptilnom nas metodom naš autor vodi dalje ističući kako nam ova faza može poslužiti, osim u pogledu spomenutog uzdizanja iznad vlastitih nam granica, također i u preuzimanju rizika i stupanja prema mogućoj pozitivnosti koja se događa u susretu mojeg ,ja““ i tvojeg „ti“. Spomenuta pozitivnost, čini se, smjera na ono što Welte ističe kao posebnu vrijednost ove faze susreta: to je mogućnost napretka osobe $-\mathrm{u}$ duhovnom, egzistencijalnom, uopće ljudskom pogledu. Time osoba jednostavno stječe vrlinu hrabrosti jer susretanje, odnosno dijalog o kojem se ovdje govori nikako nije idilično niti samo po sebi razumljivo događanje. On, kako je spomenuto, nosi rizik, međutim, pozitivnošću i napretkom prije stečenim osoba biva osposobljena u slobodi i odluci izlaganja i riskiranja s obzirom na susret. Osoba nadalje u ovoj trećoj fazi, prema našem autoru, postaje osjetljivija spram zbunjujuće sudbine novosti koju donosi svaki potencijalni susret. Welte ovu fazu također naziva zona zbrke i inhibicije kroz koju osoba jednostavno mora proći da bi (i kroz susretanje) postala ono što jest. ${ }^{34}$ Susret je, zaključimo, u ovoj fazi prepoznat kao pozitivna mogućnost u kojoj se osoba kroz svoje samoopredjeljenje ostvaruje i unaprjeđuje svoju stvarnost. U četvrtoj se pak fazi događa - na temelju svijesti vlastitog ja i u bitnom kroz osobnu odluku te povrh svega slobodu - čisti dar susreta. Na taj način ,,ja“ prekoračuje prag svojih negativnih slutnji i straha od rizika prema drugom, „ti“. U ovoj se fazi susret događa kroz plodonosni i sadržajni vid razgovora koji je takav ako osoba prekoračuje naznačeni prag. Govorim tebi, a ti meni. Osobe su u međusobnom kontaktu te su razgovor i suživot između tebe i mene uistinu na djelu.

Welte kao fenomenolog i filozof religije smatra da se u susretu događa živi razgovor životnost i životvornost razgovora za njega je važna jer se ono što on naziva „sudbina“

\footnotetext{
${ }^{34}$ Usp. WELTE B., Gesammelte Schriften I/1 Person, str. 112-113.
} 
također događa u razgovoru. ${ }^{35} \mathrm{Za}$ sada možemo samo reći da je ona u ovom kontekstu i prema Welteovim riječima trenutno zbivanje koje se rađa te se u tom smislu pokazuje kao veličina osobnog bivanja. Trenutnost se većma označava pojmom sadašnjosti. Sadašnjost je pri tom dimenzija vremena koja se razvija u susretu i razgovoru te osvjetljava prošlost novim svjetlima i slučajnostima koje kroz živi razgovor »ja-ti« dolazi do izražaja. Na ovom su mjestu stoga uključene i prošlost i sadašnjost te budućnost za koju osoba crpi bogatstvo informacija i izričaja koji susretu daju novu, višu i jasniju dimenziju i obogaćuju ljudsko osobno postojanje. ${ }^{36}$

Susretanje i s njim dimenzije dijaloga i razgovora sobom nužno povlače poimanje jastva koje doživljava vrijeme i njegov tijek. Iako suvremeni filozofi nevoljko gledaju na svaki vid kategoriziranja jastva, jedan od najboljih načina njegova prepoznavanja i potvrđivanja u ontološkom smislu (kršćanska koncepcija koju ovdje zastupamo uzima jastvo kao supstanciju, dakle ontologizira ga), jest upravo u događanju koje sami produciramo/stvaramo. Poslužimo se riječima jednog autora po tom pitanju: „Vlastito (unutarnje/vanjsko) događanje dovodi se u vezu s doživljajem vlastite osobnosti, odnosno vlastitoga ja(stva). Doživljavam svoje djelovanje ponajprije i jednostavno zato što jesam ili, drugim riječima, djelujem zato što tomu djelovanju moj ja, konkretan i odrediv, stoji u osnovi što će pak nužno utjecati na to da djelujem na onakav način kakav zapravo jesam. Te jednostavne postavke upućuju na to da vlastito ja(stvo) (su)spoznajem i kao jedno sebstvo upravo po vlastitom djelovanju i komuniciranju s okolinom. Uvid o postojanju neporecivoga odnosa između subjekta kao nositelja i čina kao izvršene kategorije upućuju u isto vrijeme i na kvalitativnu (moralnu) dimenziju, i samog djela i karaktera koji ga je izvršio. Time nužno stupamo na područje moralnosti ljudskih čina. “37 Kršćansko-tomistička misao jastvo promatra u bitnom odnosu prema pojmu duše, dakle kao supstancijalno središte vlastite osobnosti, svakako povezano s našim djelatnostima, ali u konačnici nesvodivo na njih; to je ja(stvo) dakle osnova vlastitim djelatnostima, od njih se pak razlikuje i u njima se ne iscrpljuje. ${ }^{38} \mathrm{Na}$ tragu rečenog dade se zaključiti da u oslanjanju na kršćansko-tomističke koncepcije o jastvu Welte prihvaća stav da postoji jedan ja, taj ja je supstancijalna jezgra i nositelj svih naših

\footnotetext{
${ }^{35}$ Usp. WELTE B., isto, str. 121. O pojmu sudbine ćemo nešo kasnije podrobnije govoriti.

${ }^{36}$ Usp. Isto, str. 121.

${ }^{37}$ RADIĆ S., Ontološka dimenzija (moralnoga) čina u svjetlu grijeha i krivnje, u: Diacovensia, 27 (2019) 2, str. 224.

${ }^{38}$ Usp. Isto, str. 224.
} 
karakteristika i djelovanja, koji se pak od njih razlikuje i konačno ,ja“ nikad nisam (i ne predstavljam) tek moja djela i činidbe, ali sam odgovoran za njih. ${ }^{39}$

\subsection{Osoba i svijet}

Posebno zanimljiva tema vezana uza pojam osobe za Weltea je odnos osobe i svijeta. Od početnog razmišljanja odnosa između mojeg ,,ja“ i tvojeg „ti“ došli smo do konkretnog susreta dviju osoba. Iz razmišljanja o susretu proizlazi tema sudbine koja na svoj način pripada susretu. To pak dalje vodi k tomu da se, gdje god nekog susretnem i prepoznajem kao osobu koju nazivam ti, događa ono što nas okuplja u susretu i što se prepoznaje kao „mi“. Ona nit što nas okuplja u „mi“ jest način na koji pokazujemo svoju sudbinu, koja nas snalazi neočekivano i utječe na nas u smislu da osjećamo iznenađenost, ushićenost, štoviše, čak i otuđenje, u smislu nepripadanja svijetu i drugima. Ovdje Welte u osobi kao ljudskom biću prepoznaje jednu već spomenutu hrabrost jer osoba kreće prema drugoj osobi u susret, pronalazi put do svoje vrste, sebi sličnom, nikad ne imajući potpunu spoznaju o tome što ju na tom putu može snaći. Upravo se u tome nalazi i prepoznaje pojam sudbine. Razmatrajući sudbinu susreta dviju osoba, dolazi se i do pojma brige o vremenu koje dolazi, a koje dakle pripada ovoj sudbini susreta. Vrijeme koje ovdje valja promotriti nije ono vrijeme koje uočavamo kada pogledamo na sat, nije ni ono izvanjsko vrijeme koje prepoznajemo po prirodnim ciklusima, nego vrijeme koje je sadašnjost u kojoj se susret događa, to jest koje je na djelu. Susret stoga donosi vrijeme kao sadašnjost. Welte će reći da se u susretu prepoznaje „punoća prisutnosti sudbine“. ${ }^{40}$ Oni koji se susretnu uvijek će moći reći: sad je to tako. Stoga su i njihova djela prilagođena i dovedena kao sadašnjost njihove sudbine.

Određivanje vremena kao prisutnosti sudbine nije samo mjerilo onog što se događa, nego i mjerilo osobe jer se u susretu zbiva živo događanje i prepoznavanje bića. Nadalje susret sve mijenja, a sve što je do tada bilo sada je drugačije. Susret otvara nove vidike koji se imaju zbiti u budućnosti, nove mogućnosti i nove nade. Cjelokupna struktura vremena sada dobiva kvalitativno novi poredak jer nova sadašnjost nastaje iz susreta i tako obogaćuje budućnost. ${ }^{41}$ Kada se dogodi okupljanje između mojeg ,ja“ i tvojeg „ti“, tada se događa i sudbina, trenutak i vrijeme. $U$ tom procesu zajedništva dolazi do, Welteovim riječima, sazrijevanja čitave strukture vremena. Što je sa svijetom - mogli bismo se ovdje zapitati?

\footnotetext{
${ }^{39}$ Usp. Isto, str. 224.

${ }^{40}$ Usp. WELTE B., Gesammelte Schriften I/1 Person, str. 121-125.

${ }^{41}$ Usp. Isto, str. 121-125.
} 
Svijet je u kontekstu ovog događanja poput izvjesnog prostora sudbine, sveobuhvatnog horizonta u kojem se susret između dvije osobe odvija i ima svoju ograničenost. ${ }^{42}$ Svijet pripada, ističe Welte, osobi i životu na više načina. U procesu zajedništva dolazi do sazrijevanja čitave strukture vremena i tada dolazimo do pitanja kako zapravo svijet funkcionira. Njemački filozof religije nudi nekoliko pojašnjenja na to pitanje.

Prvo, radi se o pripadnosti svijeta osobi. ${ }^{43} \mathrm{Na}$ početku zamjećujemo kako se susret između ,ja“ i ,ti“ događa na već pripremljenom terenu koji prepoznajemo kao svijet. Svaka je djelatna osoba u susretu originalna te utjelovljena u svijetu koji ga podržava. Iz mogućnosti susreta razaznaju se i sposobnosti koje osoba posjeduje i u svijetu primjenjuje. Osoba svoje sposobnosti i vještine primjenjuje i koristi u svijetu jer je svijet, ma kakav bio, to jest ma kakav se on nama činio, ipak već prilagođeno mjesto za suživot dviju osoba koje se susreću. Ta „spremnost“, to jest „prilagođenost“ svijeta prvotno da nas primi, zatim omogući susretanje dijelom je plod naših ljudskih djelatnosti. Svijet kao prirodno mjesto za osobu, kao i osobe u susretu, uključuje biološke, sociološke, a posebno jezične odrednice ljudskog postojanja. Svaka je osoba uvijek nešto novo u tom svijetu, neusporediva s bilo kojom drugom i ta neusporedivost ima za posljedicu dostojanstvo koje joj je pripadno. Osoba je konačna, ali živi dakle u zajedništvu već pripremljenog tla svijeta i taj je svijet priroda njezina osobnog života u kojem se odvija sve moguće događanje, uključujući i susrete kao takve.

Drugi vid pripadnosti svijeta osobi jest taj da svijet kao priroda jednostavno nikad ne miruje. ${ }^{44}$ Uvijek je neko događanje. Gdje god osoba živi, događa se dinamika i osoba se, jasno je, u tome mijenja. Osoba poseže za mogućnostima koje svijet nudi, na taj se način ona može razviti i postajati boljom osobom od one kakva je bila jučer. Svijet nije više za osobu samo priroda, već polje osobne realizacije, i u tom položaju svijet stoji kao svijet nasuprot onom prvotnom vidu svijeta kao prirode. Na taj se način osoba samoostvaruje unutar svijeta, prepoznaje svoje mogućnosti što posljedično donosi početak promjene samog svijeta: ako se mijena osobe događa na kvalitativno višoj razini, onda i svijet oko nje postaje boljim mjestom za život. Bez svijeta osoba ne bi mogla učiniti ništa niti postati itko. Sve ovo ukazuje na zaključak da svijet u bitnom „surađuje“ ili bolje sudjeluje u ostvarenju osobe. Ona upravo u svijetu biva aktivna, ostvaruje svoje ideje, živi svoje navike i ide za svojim ciljevima. ${ }^{45}$ To više nije samo priroda, nego takav svijet poprima osobnu dimenziju.

\footnotetext{
${ }^{42}$ Usp. Isto, str. 124.

${ }^{43}$ Usp. Isto, str. 122.

${ }^{44}$ Usp. Isto, str. 123-124.

${ }^{45}$ Usp. WELTE B., Gesammelte Schriften I/1 Person, str. 122-123.
} 
Radeći i živeći u svijetu, osoba stvara svoj svijet kao svoju kulturu, jezik, tehnologiju itd. Upravo zbog toga možemo s Welteom govoriti o svjetovima unutar svijeta. I još više: to je ono što nazivamo svjetsko vrijeme koje uvijek proizlazi iz života osobe, iz susreta i sudbine koja iz tog susreta biva razvidna. Upravo to što se stalno događa i način na koji se osoba razvija tvori svijet i svjetsko vrijeme. ${ }^{46} \mathrm{U}$ tome je objektivna karakteristika vremena. Važnim se nameće ukazati na to da se na ovom mjestu Welte poziva na Hegela i njegovu razradu apsolutne ideje koja nije dio objektivnog duha, a religija je za Hegela drugi stupanj apsolutnoga ${ }^{47} \mathrm{Na}$ trenutak se može učiniti kako su stvoreni svijet i svjetsko vrijeme dio cjeline objektivnog duha, međutim, kako smo rekli, on ga utemeljuje, ali je ipak to još uvijek moj, vaš i naš svijet koji dakle ja tvorim. Uz odnos osobe i svijeta uvijek se vezuje i pojam susreta i upravo je susret taj koji daje smislenost cjelokupnom životu osobe. Tako se svijet opet pojavljuje kao polazište za osobu i njezino ostvarenje te onaj koji s njom, kako istaknusmo, sudjeluje u ostvarenju nje same. Ako je to prvo bilo tlo s kojeg se osoba izdiže u svojim počecima te zatim polje ostvarenja koje joj je dodijeljeno, sada se čini kao ono što je obuhvaćeno značajem osobnog, a time i kao svijet koji poprima ljudsku dimenziju - ne dakako u moralnom, već u egzistencijalnom smislu - i koji je kao takav u potpunosti razvijen za ljude.

Welte nadalje donosi pojam dijalektike koja se ovdje pokazuje u čovjeku i svijetu. ${ }^{48} \mathrm{~S}$ jedne strane svijet je dan i razlikuje se od osobnog. S druge strane samo ga osobno razvija kao svijet, stvara i zadržava u punini značenja osobnog. Stoga svijet i vrijeme koje napreduje pripadaju području osobnog života. Welte ovdje donosi pojam igre gdje je svijet uvijek pripremljeno područje za igru, a osoba uvijek iznova igra tu igru i neprestano razvija svoje sposobnosti i vještine kako bi bolje živjela u svijetu. Zbog čega se Welteu igra učinila ovdje važnom? Ako, naime, u poslu, odnosno obvezama doživljavamo napor te tako dakle uz svojevrsno sebe-slamanje rješavamo (životne) zadaće i probleme koji nailaze, tada sama

\footnotetext{
${ }^{46}$ Nešto slično imamo u Heideggera gdje »tubitak« sebe vremeni i zato i jest svijet, tako je u Welteovu slučaju osoba ta koja tvori svijet i svjetsko vrijeme. U Weltea je također više naglasak na sadašnjosti koja tek treba oblikovati budućnost, a u njegova učitelja Heideggera sadašnjost je ta koja na neki način iskače iz budućnosti i bilosti. Usp. ŠEGEDIN P., Svjetovanje svijeta (Bitak i vrijeme, §§14-24, 69-71), Bitak i vrijeme. Interpretacije, Zbornik radova, BARBARIĆ D., ur., Matica hrvatska, Zagreb, 2016., str. 13-68.

47 Vrhunac jenske razradbe filozofije duha, koju je Hegel prethodno izlagao kao sustav ćudorednosti, donosi Fenomenologija duha, po nekima njegovo najutjecajnije djelo. Pisana je kao prvi dio filozofskog sustava, zato sadrži i propedeutičku zadaću, a poslije je u enciklopedijskom prikazu svedena u okvire subjektivnog duha. Prikazuje stupnjevito samouspostavljanje duha, povijest iskustva samosvijesti polazeći od izravnog iskustva stvari, osjetilne izvjesnosti, preko svijesti i razuma, pa zatim do uma, duha i religije. Konačni stupanj razvoja duha uspostavlja navlastiti filozofski odnos kao apsolutno znanje u kojem duh ima za predmet sebe sama, u: Hrvatska enciklopedija, mrežno izdanje. Pristupljeno 3. 9. 2020. Dostupno na: https://www.enciklopedija.hr/natuknica.aspx?id=24745

${ }^{48}$ Usp. Isto, str. 124
} 
djelatnost biva redovito teška. Nasuprot tome $u$ igri se ta ista djelatnost događa $s$ jednom neobjašnjivom lakoćom: napor je prisutan, no što je on veći, to je veća i sposobnost rješavanja prepreka koje neprestano iskaču. Za pojam igre Welte pronalazi inspiraciju u filozofiji L. Wittgensteina kojeg i spominje. Naime, u svom posthumno objavljenom djelu Logička istraživanja iz 1953. godine Wittgenstein spominje pojam jezične igre kako bi ukazao na specifičnosti koje filozofski jezik posjeduje. Spominjanjem jezične igre Wittgenstein zapravo stavlja naglasak na djelatnu dimenziju jezika. U svojim razmatranjima o jezičnoj igri stvaratelj Logičkih istraživanja kaže sljedeće: „Ubuduće ću opet i opet svraćati (...) pozornost na ono što ću zvati jezičnim igrama. One su način uporabe znakova jednostavniji od onih na koje mi upotrebljavamo znakove u svojem veoma složenom svakidašnjem jeziku. Jezične igre jesu oblik jezika s kojima dijete počinje upotrebljavati riječi. Učenje jezičnih igara je učenje primitivnih oblika jezika ili primitivnih jezika،“"49 Iz priloženog se navoda može zaključiti kako je ovdje zapravo istaknut jezik. Nezaobilazna dimenzija Welteova filozofiranja jest upravo ova forma ljudskog postojanja, naime, na način govornog bića. Jezik stoga igra iznimno važnu ulogu te uz svijet i vrijeme, kao dimenzije osobnog čovjekova razvoja, također vodi i osvjetljava čovjekovo postojanje u svijetu.

\subsection{Osoba i jezik}

Do sada smo objasnili neke od osnovnih dimenzija osobnog života. Dimenzija vremena jest ona u kojoj se sudbina događa kao dar onima koji se susreću. ${ }^{50}$ Dimenzija svijeta koji se prepoznaje kao priroda koja okuplja i štiti, nosi sav osobni život, koji u susretu dostiže svoju puninu. Svjetsko vrijeme pri tome jest dimenzija odvijanja sudbine cjelokupnog osobnog života. ${ }^{51} \mathrm{U}$ tu se svrhu mora imenovati i razmotriti treća dimenzija u kojoj se sve slaže, a to je dimenzija jezika. Cjelokupni život započinje i nastavlja se kroz susret između mojeg ,ja“ i tvojeg „ti“. Jezik kao razgovor jest izvorniji od jezika koji se promatra samo kao skup riječi i oblika, gramatičkih pravila i sintakse. Izvorniji u smislu jer se u njemu pojavljuje i odvija dijalog, živi susret između dvije ili više osoba. Dakle na jezik treba gledati kao na pojavu razgovora koja izvire iz osobnog susreta. Jezik je dakle, prema Welteu, prvotno

\footnotetext{
${ }^{49}$ Usp. FROMM S., Wittgensteins Erkenntnisspiele kontra Kants Erkenntnislehre, Symposion Alber, Freiburg, 1996., str. 267.

${ }^{50}$ Usp. WELTE B., Gesammelte Schriften I/I Person, str. 125.

${ }^{51}$ Usp. Isto, str. 125.
} 
događanje koje svoju bitno odrednicu pronalazi u susretu razgovaranja te koji bi bez njega postao radikalno osakaćen. ${ }^{52}$

Ondje gdje se susret odvija kao razgovor on se odvija na putevima jezika koji su već otprije prisutni. Jezik iz te perspektive možemo tumačiti kao prirodu, osnovu razgovora (analogno tome kako svijet kao priroda u početku susreće i osobnost). ${ }^{53}$ Razgovarajući, ne trebamo izmišljati jezik, nego uvidjeti kako jezik oduvijek jest. Obično ne trebamo razmišljati o odabiru riječi, već se jezik u razgovoru pokazuje kao nešto najprirodnije za osobu tako da već i u kolokvijalnom govoru kažemo da u tim situacijama „riječi naviru same od sebe“. Welte kaže kako je jezik sam dizajnirao puteve mogućnosti govora $\mathrm{i}$ to je tako od davnina. Kroz razgovor se u jeziku prepoznaje njegov uvijek dinamični, okretni, neprestano razvijajući karakter. Ovdje se Welte poslužio Heraklitovom izrekom kako „ne možeš dva puta ući u istu rijeku“, kao što se ne možemo služiti „istim“ jezikom dva puta u razgovoru s drugim. U tom smislu jezik nije poput nekog doslovno tehničkog pomagala, alata, pri čemu bi bilo važno dotično oruđe samo precizno primijeniti i učinak ne može izostati, odnosno premješteno na jezik, on bi tu savršenoj „tehničkoj“ izvedbi sasvim ispunio svoju ulogu. Nasuprot tome jezik je rezultat uvijek novog suočavanja s drugom osobom kroz razgovor. ${ }^{54}$ Upravo zato i razumijemo tezu za koju je Welte želio da se ispravno shvati, a to je da jezik kao razgovor predstavlja otvorenost cjelini susreta koji se stalno iznova događa, i to u svojoj originalnosti. Konačno, radi se o istini postojanja kojoj svi svjedočimo jer je u interesu svih ljudi i njihovog razgovora dosegnuti istinu postojanja, kako ju Welte i označava.

Međutim, ta istina nije i ne može biti dosegnuta u ovosvjetskim okvirima, nego uvijek ostaje označena kao hod k Vječnosti, k onome što se naziva eshaton. ${ }^{55}$ Pojam eshatona, koji i Welte ovdje dotiče, postaje iznimno važan. To nije nikakav eskapizam, bijeg s jezikom u onostranost, pri čemu bi se kod prigovora nerazumljivosti i nedorečenosti jezika ukazivalo na njegovu nemogućnost dosezanja eshatološke, nedovršene dimenzije. Eshaton, odnosno vječnost u razmatranjima o jeziku kod Weltea imaju za cilj ukazati na otvorenost, dinamiku i razvoj samog jezika s obzirom na sva područja (ljudskog) postojanja pri čemu (i) vječnost zauzima važno mjesto, a prema kojem se jezik kreće, pokušava ju pojmovima i izričajima dosegnuti. Tako ono što se događa u susretu i jeziku koji se njime ostvaruje jest zrcaljenje bitka, ali je u isto vrijeme i u znaku bezuvjetnog, u znaku vječnosti. Stojeći pred

\footnotetext{
${ }^{52}$ Usp. Isto, str. 126-127.

${ }^{53}$ Usp. Isto, str. 127.

${ }^{54}$ Usp. Isto, str. 129.

${ }^{55}$ Usp. Isto, str. 129-130.
} 
nagovještajem i poticajem vječnosti, njegova (čovjekova) je narav, odnosno u njezinoj je najdubljoj osnovi uvijek pokušati dati odgovor. On živi odjek onog što nazivamo vječnost i što se doživljava u eshatonu. ${ }^{56}$

Ovaj dio svojeg promišljanja Welte završava idejom M. Bubera koji u svojem čuvenom odnosu između ja i ti iščitava odnos spram vječnosti. ${ }^{57}$ Svaki govor onom kojeg nazivamo ti jest naše obraćanje i govor Vječnome. Buber je poistovjetio religiju s Prisutnošću i pritom udaljavao svaki „ti“ iz područja objekta. On (Buber) uspostavlja odnos prisutnosti u kojem se religioznost razlikuje od religije koja je izražena u čovjekovu djelovanju. U tom smislu prelazi put od „iznimke“, kao iskustva drugosti koje ne pronalazi svoje mjesto u redovitoj dimenziji čovjekova bivstvovanja, do prisutnosti koja postaje temelj i nositelj čovjekova postojanja jer svi naši odnosi pronalaze svoje ispunjenje i smisao upravo u tome da traju, pa i kroz vječnost. Konačna pak svrha svega rečenog, s obzirom na odnose, jest u vječnom Ti. ${ }^{58}$ Dijalog, susret i odnos nisu dekorativne kategorije naše religioznosti, nego put koji nas vodi do toga da podnosimo cjelokupnu stvarnost. ${ }^{59}$ Buberova je nakana potvrditi spoznaju da je bit religioznosti čovjekovo djelovanje, među ostalim, i s obzirom na stvaranje odnosa koje pak održava na životu iskonski dijalog između Boga i čovjeka. ${ }^{60}$

\subsection{Osoba i kršćanstvo}

Do sada smo predstavili područje osobnog života u nekim od njegovih najvažnijih dimenzija: dimenzija vladajućeg svijeta kojoj smo mjerilo ,ja“ i „,ti“; dimenzija vremena koja se odvija kroz sudbinski susret u razgovoru koji uvijek iznova napreduje; dimenzija jezika u kojem se odvija razgovor i koji se istovremeno obnavlja i razvija kroz razgovor, jezik u kojem se svijet i vrijeme spajaju onima koji međusobno razgovaraju. Ovu višedimenzionalnu cjelinu osobnog života, koja se pojavljuje kroz sudbinski susret u razgovoru između osoba, Welte

\footnotetext{
${ }^{56}$ Usp. Isto, str. 134-135.

${ }^{57}$ Usp. Isto, str. 135.

58 AKRAP A., Fenomenologija prisutnosti. Apsolutno, religija i filozofija u misli Martina Bubera, u: $B S, 85$ (2015) 4, str. 979-1005. Navedeni se izričaji svakako mogu doimati kao svojevrsne hiperbole, čak i u pogledu filozofije religije jer se postavlja banalno pitanje što znači da se naši susreti događaju u perspektivi vječnosti i vječnog Ti, poglavito za one koji u tu kategoriju uopće ne vjeruju. Rješenje koje ovdje možemo ponuditi s obzirom na navedenu problematiku polazi upravo od fenomenologije ljudskih iskustava, a ne od vjerovanja ili ne-vjerovanja u Transcendenciju. Kada smo, naime, u nekom kvalitetnom odnosu, koji dugoročno izaziva istinsku i duboku sreću, tada jednostavno želimo da to traje unedogled ili jednostavnije u vječnost. To se posebno tiče bračnih i obiteljskih odnosa, to jest dijaloga, razgovora itd.

${ }^{59}$ Isto, str. 980.

${ }^{60}$ Isto, str. 980-985.
} 
naziva zov vječnosti. ${ }^{61}$ Stupnjevi kroz koje prolazi osoba u životu približavaju se najvećoj mogućnosti u vječnosti. Mogućnost susreta s Vječnim izvire iz bitnih dimenzija osobnog života i tako na vidjelo dolazi odnos osobe, osobnog i kršćanstva koje zahtijeva razumijevanje i daljnje tumačenje.

Na početku je potrebno razjasniti što je kršćanstvo i od kojeg se trenutka kršćanstvo naziva kršćanstvom. Odgovor na to pitanje, Welteovim riječima, jest da se kršćanstvo temelji na iskustvu Boga u Isusu Kristu. ${ }^{62}$ Ovo odlučujuće božansko otkrivenje presudni je i konstitutivni element kršćanstva. Bitni element kršćanstva (objava Boga u Kristu) postaje vidljiv kao mogućnost iz osnovnih uvjeta osobnog života i može se razumjeti u njegovoj potvrđenoj stvarnosti. Nisu toliko bitni izvanjski događaji, već susreti između osoba obogaćuju stvarnost osobnog života i daju živo iskustvo vjere i pouzdanja. Zajednica učenika naziva se Crkvom. Crkva je, Welteovim riječima, zajedništvo osoba koje sudjeluju u susretu i koje su okrenute jedne prema drugima te zajedništvo vjernika. Cjelokupni život osobe ogleda se kroz razgovore i susrete, a Crkva kao zajednica vjernika, u kojoj se ti isti susreti događaju, na taj se način neprestano razvija. Ona po sebi nije samodostatna, sebi-dovoljna i strogo fiksirana institucija na neko mjesto, to jest područje, vrijeme, iako zahtijeva institucionalne elemente kao i sve druge zemaljske zajednice. Welte će reći kako je Crkva život koji se odvija u uzajamnosti. Događaji Crkve se temelje na vjeri, to jest neprestano obnavljajućem vjerničkom susretu s osobom i događajem Isusa Krista. Vjernici žive od ovog osnovnog događaja osobne prirode - odnosa sa osobom Isusa Krista, i na temelju toga zajednica vjernika čitav svoj život koncentrira i uzvisuje u svetom slavlju u kojem taj odnos zadobiva svoju vidljivu formu. Budući da je to slavlje sjećanja, s bitnom kategorijom posadašnjenja, u kršćanskom je svetom slavlju sveukupno slavlje Crkve osobni susret s Isusom Kristom, to jest s događajem Božje objave u njemu. Kršćanstvo (Crkva i zajednica vjernika) živi kroz događaj Isusa Krista i u stalnom prisjećanju i slavljenju toga događaja. To je trajni susret i razgovor koji obuhvaća ljude koji vjeruju. Uvijek se događa nešto novo, neki novi poziv i odgovor u uvijek živom osobnom susretu u vjeri. Kroz povijest su se razvijala povijesna kršćanstva Istoka, Zapada, reformacije i protureformacije, i u vezi s njima razvijale su se nove epohe i modusi kršćanstva. Welte je mišljenja kako svi oblici povijesnog kršćanstva pripadaju tijeku jednog te istog kršćanstva jer se svi temelje na neprestano obnavljajućem jednom temeljnom susretu vjere s jednim objaviteljem - Bogočovjekom Isusom Kristom. Ovaj susret jest za sva kršćanstva nezaboravan, jedinstven i čini sva kršćanstva jednim kršćanstvom. Stvarnost

\footnotetext{
${ }^{61}$ Usp. WELTE B., Gesammelte Schriften I/1 Person, str. 135.
}

${ }^{62}$ Usp. Isto, str. 136. 
govora, odnosno razgovora i ovdje se pokazuje vrlo važnom. Prema filozofu iz Freiburga, upravo zbog toga, objave u Isusu Kristu, utjelovljene Riječi, to jest govora, kršćanstvo uvijek ostaje živo kroz susret u dijalogu i to posadašnjenjem ovog temeljnog susreta/razgovora Isusa s apostolima i drugim svjedocima Evanđelja. S obzirom na rečeno kršćanstvo stoga i u mnogim drugim „logoima“ stvara novu sadašnjost od onog uvijek obnavljajućeg početka svog osnovnog događaja i nikad ne može učiniti uzmak od (raz)govora, jezika jer se uvijek mora odgovoriti na ponudu božanskog na način upravo (raz)govora, odnosno odgovora. Taj odgovor u vidu govora, dijaloga nikad nije i ne može biti završen, nego je otvoren budućnosti. Možemo govoriti i o savršenstvu svih koji sudjeluju u tom osobnom susretu kroz razgovor i slavlje u jednom i cjelovitom Kristovu događaju. ${ }^{63}$ Kršćanstvo kao razgovor - kao i svaki razgovor, ali na poseban način - uključuje prošlost i sadašnjost i konačnu budućnost. Kršćanstvo je u konačnici nastalo te se održava kao događaj dijaloga i razgovora.

Čini se kako se u novije vrijeme pokazuje da su sva kršćanstva, odnosno svi njegovi oblici bliski te univerzalni razgovor koji svi razumiju postaje sve neophodniji. To se pojavljuje i kao zahtjev za budućnost. No ne smijemo biti usredotočeni samo i jedino na budućnost, a što je česta pojava suvremenog doba. Osobe su toliko usredotočene na buduća postignuća i razvoj tehnike, znanosti koje žele ostvariti te zbog toga sadašnjost i aktualni trenutak ostaju na margini. Zbog toga je potrebno ponovno promisliti cjelovitost koju osoba posjeduje te uz intelektualnu dimenziju dati priliku i drugim aspektima duhovnog života te tako ostvarivati susrete $\mathrm{i}$ povezati se s drugim osobama u univerzalnom razgovoru $\mathrm{u}$ sadašnjosti koja će zatim u konačnici oblikovati budućnost susreta s onim vječnim „Ti“ ${ }^{64}$ To je poziv koji Welte upućuje svakom kršćaninu, naime, da promisli svoje postojanje i svoja djela te ih uskladi s onim Vječnim u sebi što će ga dovesti do konačnog spasenja. Welte lijepo zaključuje ovaj dio svog promišljanja kada kaže kako je jedino univerzalni razgovor koji sve povezuje i u povijesti kršćanstva zadatak koji osoba koja se naziva kršćaninom treba nužno slijediti. ${ }^{65}$ Stjepan Kušar zanimljivo govori o postojanju „religioznog oka“ ili „,antene“ u čovjeku, što je zapravo apsolutni moment u čovjekovoj spoznaji i slobodi. ${ }^{66} \mathrm{Na}$ taj je način čovjek sposoban odgovoriti na poziv Vječnoga u sebi samom. Budući da su to fenomeni, kako Kušar kaže, dostupni umskom promatranju i refleksivnoj raščlambi, moguće je u njima otkriti kako čovjek kao duh u svijetu u svim iskustvima spoznavanja nečega i htijenja nečega su-

\footnotetext{
${ }^{63}$ WELTE B., isto, str. 134.

${ }^{64}$ Vječno »Ti« pisano velikim slovom u disertaciji, kao i kod Weltea se odnosi na Boga.

${ }^{65}$ Usp. WELTE B., Gesammelte Schriften I/1 Person, str. 135.

${ }^{66}$ Usp. KUŠAR S., Filozofija o Bogu, KS, Zagreb, 2001., str. 42.
} 
iskušava jedan apsolutni ili bezuvjetni moment ili apsolutnu točku koja se pokazuje kao transcendentni uvjet mogućnosti svakog spoznavanja i htijenja. ${ }^{67}$ Čovjek kroz transcendenciju otkriva istinu o sebi i svojoj osobi. Tu istinu otkriva ne samo kroz mistična iskustva nego, kako je to Welte također isticao i na konkretnim primjerima uočavao, kroz susrete, kroz zajedništvo, suživot s drugom osobom s kojom živi i djeluje.

\section{Odlučnost i sloboda u kontekstu govora o osobi}

\subsection{Uvodna razmatranja}

Spis Odlučnost $i$ sloboda Welte je napisao 1966. godine. On uvelike pomaže razumijevanju osobe kako je to Welte želio da ju se razumije. U raspravi i prepiskama, odnosno razgovorima s bliskim prijateljima Welte je uvidio kako odlučnost i sloboda zahtijevaju jedno novije, modernije tumačenje koje treba uključiti moderno istraživanje ponašanja samog čovjeka. Stoga prvo što njemački filozof uzima u obzir bila su bihevioralna istraživanja čovjekova djelovanja, to jest ponašanja i govora, kako bi se pitanja o čovjekovoj slobodi mogla raspraviti iz mnogih uglova, koja su svakako korisna i potrebna kako bi se došlo do boljeg razumijevanja pojmova kojima se označavaju temeljni aspekti osobnosti, odnosno onog što ljudsku osobu čini onim što jest, poput slobode, stvarnosti koja je čovjeku uz svijest vlastitog jastva nešto najbliže i najintimnije. ${ }^{68}$ Sloboda pak, prema Welteu, nužno uključuje odlučnost koja ovoj stoji u pozadini. Ona kao vrlina jednostavno aktuira slobodu, što ide u prilog zaključku da je odlučnost zapravo uvjet mogućnosti slobode. Prema Welteu, čovjek se za slobodu, koliko god mu bila sama po sebi dana, mora tek izboriti. Odlučnost je ta koja čovjeka nagoni, zahtijeva, traži da neprestano otkriva ispravni put hoda kao ostvarenje vlastite slobode. Odlučnost ovdje ima, prema našem autoru, u bitnom karakter hrabrosti. Radi se u konačnici o svojevrsnom zadobivanju slobode za nju samu (slobodu). Sloboda nije tek nešto što je sāmo po sebi pretpostavljeno te se njome treba samo poslužiti, već stvarnost do koje treba doći. Valja reći s druge strane da sloboda ukazuje i na temeljni problem ljudske egzistencije: naime, mnoge filozofije i pravci ne drže ju u njezinoj antropološkoj danosti, stvarnom i time ostvarivom, već kao konstrukt kojim se služimo u nadvladavanju svakodnevice, odnosno ,preživljavanju“. Welte se ovom stavu, jasno, protivi, na tragu kršćanske tradicije pri čemu, slično kao i kod pojma jastva, samu slobodu u izvjesnom smislu

\footnotetext{
${ }^{67}$ Isto.

${ }^{68}$ Usp. WELTE B., Gesammelte Schriften I/1 Person, str. 12.
} 
ontologizira. I dalje kod njega upravo pojam i vrlina »odlučnost« u kontekstu slobode ukazuju na to da se one nužno isprepliću, i to tako odlučnost, kako je netom rečeno, omogućuje slobodu, međutim, sloboda, to jest slobodan čin očituje i manifestira, iznosi na vidjelo momente kada je čovjek uistinu odlučan i hrabar, dakle samu odlučnost, odnosno hrabrost. U tom je smislu slobodu, po našem autoru, nemoguće (pro)tumačiti bez odlučnosti (hrabrosti), dok se s druge strane odlučnost pokazuje u donošenju konkretnih, većinom hrabrih odluka u temeljnim životnim pitanjima.

U kontekstu ova dva pojma pojavljuje se kod Weltea još jedan: samo-ponašanje. Ovaj pojam kod autora ima značenje izvjesnog oslobađanja koje osoba provodi i koje se događa kroz nadilaženje svjetovne volje. Spomenuti pojam samo-ponašanja i oslobađanja koje osoba zadobiva ima cilj ukazati na to da osoba biva pozvana na otvorenost, ali i da je izložena sveobuhvatnom koje sve nadilazi i posjeduje bezuvjetnu transcendenciju svog bića. ${ }^{69}$ Osoba je na ovaj način pozvana promatrati samu sebe i u okviru toga svoju slobodu te promišljati tako da uvidi kakva je ta sloboda, je li ona stvarna, istinska ili pak nečim uvjetovana. Prema Welteovu mišljenju, osoba se uvijek nalazi u opsegu moguće slobode. Sve su mogućnosti otvorene, a na osobi je da iskoristi svoja znanja i mogućnosti kako bi ta sloboda bila potpuna i bez ikakve izvanjske prisile. Unutar onog što Welte naziva samo-ponašanje (ono samo-dano) dade se primijetiti kako unutar tog djelovanja koje je usko vezano uz pojam slobode postoji i nešto drugo, nešto puno veće od onog što promatramo kao determinativne dijelove prirode $u$ okviru kojih osoba živi i postoji. Osoba počinje gledati sebe kao cjelinu u smislu onog što ona jest (cjelokupna priroda, pa i neke složenice koje uviđa kao sebi pripadne).

Kada osoba započne samo-promatranje kroz pojam samo-ponašanja, do izražaja dolaze dva moguća puta. Osoba se pita kako se ponaša prema prirodi i svom prirodnom okruženju (tamo gdje se zatekla u postojanju), stoga na tom prvom polu stoji cjelokupno ponašanje prema svim vidovima onog izvanjskog koje u bitnome vodi pročišćenju postojanja uopće jer smo dio prirode. ${ }^{70} \mathrm{Na}$ drugom se pak polu nalazi jastvo gdje se čovjek pita tko je on kao osoba te kakva mu je vlastita priroda. ${ }^{71}$ Odgovori na ta pitanja proizlaze iz Welteovih shvaćanja pojmova slobode te ćemo se u nastavku (ponovno) vratiti ovom pojmu, odnosno načinu na koji sloboda biva objektivirana u kontekstu Welteova promatranja osobe.

\footnotetext{
${ }^{69}$ Usp. Isto, str. 65.

${ }^{70}$ Usp. Isto, str. 65-66.

${ }^{71}$ Usp. Isto, str. 65-66.
} 
Kontekst, odnosno okružje, prirodno i društveno, u kojem živi i stasa osoba presudno je za njezino cjelokupno oblikovanje, kao i za stvaranje uvjerenja i stavova. Svaka je racionalna osobnost, to jest čovjek uvjeren da stavove i opredjeljenja donosi slobodno. U modernoj se znanosti, poglavito onoj fizikalnog usmjerenja poput empirijske psihologije, psihijatrije, kao i filozofijā bliskih njima, sloboda označava kao ona koja je krajnje deterministički i time kauzalno određena. Welte je pak mišljenja kako je sloboda jedan od temeljnih fenomena ljudskog postojanja na koji se ozbiljno računalo, stoga ju se ne može svoditi na druge psihološke i antropološke fenomene. ${ }^{72} \mathrm{U}$ filozofskoj se tradiciji pitanjem slobode najiscrpnije bavila filozofska antropologija. Poštujući zasade filozofske misli o slobodi, naš filozof smatra da pitanje o slobodi treba iznova promisliti, pristupajući mu s dužnom pozornošću. Naime, s obzirom na spomenuta ograničenja, štoviše, i negiranja od strane pojedinih znanstvenih, ali i filozofskih smjerova, Welte je s pravom ukazao na potrebu i važnost govora o pozitivnom određenju slobode. Sloboda je pozitivna sastavnica ljudskog postojanja. Sasvim jasno stoga valja istaknuti da za Weltea čovjek nije neslobodno biće, nije ograničen fizičkim ili mentalnim mehanizmima niti društvenim uvjetovanostima. ${ }^{73}$

\subsection{Savjest - čovjekov „duhovni““ putokaz prema dobru}

Welte se zaustavlja na pojmu slobode upravo zbog drugih, temeljnih danosti vezanih uz njih, poput savjesti i odgovornosti koje pak po njemu bitno pripadaju onom religioznom. Savjest se javlja kao unutarnji glas koji pomaže osobi odgonetnuti što je to ispravno i kako može ostvariti puni potencijal svoje osobne slobode i odgovornosti. Upravo kroz savjest osoba biva pozvana i sposobna uvidjeti razliku između onog što nazivamo dobro spram onog što uz pomoć zdravog razuma možemo označiti kao zlo. ${ }^{74}$ I. Tićac kaže kako je savjest fenomen sui generis. Ona se pojavljuje u dva oblika. Prva je forma savjest kao synderesis. Ovdje se radi o općim praktičkim načelima koji su primjereni umu. ${ }^{75}$ Ista autorica donosi sljedeće o savjesti: „Ona je praktička savjest o ćudorednom dobru. Savjest u drugoj formi je primjena znanja o općim ćudorednim principima na konkretno djelovanje. Ćudoredni principi i ćudoredne dužnosti ne spoznaju se putem savjesti u užem smislu te riječi. Iako je savjest čin suda, ona nije spoznajni organ. Čin savjesti je čin poslušnosti prema istini i istovremeno

\footnotetext{
${ }^{72}$ Suvremeno doba svakako nije jedino u kojem se stavljala u pitanje stvarnost slobode.

${ }^{73}$ Usp. WELTE B Gesammelte Schriften I/1 Person, str. 12-19.

${ }^{74}$ Usp. Isto, 12-19.

${ }^{75}$ Usp. TIĆAC I., GUŠIĆ A., Uloga savjesti u etičkom prosuđivanju i djelovanju, u: Acta Iadertina, 4 (2007) 311 , str. 9 .
} 
najviši čin odgovornosti, vladanja i raspolaganja sobom. S obzirom na čine na koje se odnosi sud savjesti razlikuje se savjest koja prethodi činu (constientia antecedens) i savjest poslije čina (constientia consequens) “. ${ }^{76}$ Kada se nadalje radi o savjesti, razlikuju se ispravna $\mathrm{i}$ pogrešna savjest. Ispravna je savjest ona koja ispravno primjenjuje kriterije i norme po kojima treba djelovati, to jest ona koja je u suglasju s objektivnom moralnošću. ${ }^{77}$ Pogrešna je savjest ona u kojoj pojedinac vjeruje da je neko djelovanje moralno ispravno, dok to zapravo nije slučaj. Zato se pokazuje veoma važno pravilno odgojiti savjest kako bi se znalo dobro prosuditi vlastite čine. Svaki je čovjek pozvan ustrajati u nastojanju da oblikuje ispravnu savjest. ${ }^{78}$ Kako bi osoba oblikovala ispravno svoju savjest, bitnim se pokazuje i dimenzija razuma koju osoba obogaćujući novim spoznajama koristi za ojačanje vjere u vlastite sposobnosti. ${ }^{79}$ Kada se radi o savjesti, u razmatranje je nužno uključena dimenzija moralnog zakona. Sv. Toma Akvinski moralni zakon opisuje kao „naravno svjetlo uma u kojem razlikujemo ono što je dobro od onoga što je zlo. ${ }^{80}$ Autorica Tićac uvjerljivo nastavlja o moralnom zakonu i autonomiji: „Čovjekova istinska moralna autonomija ne znači odbacivanje, već prihvaćanje moralnog zakona. Savjest ne dokida našu slobodu već ju veže i obvezuje, već je zapravo utvrđuje. Razlog tomu leži u činjenici da je snaga njezine obveze zapravo snaga istine“. 81

U govoru o savjesti u kontekstu Welteova razmatranja osobe važnim se nameće spomenuti Dokument II. vatikanskog sabora. Gaudium et Spes (Vjera i nada) tako u broju 16 govori kako savjest otkriva čovjeku zakon od „Boga u srcu zapisan“ kojem se treba pokoravati da bi činio dobro i izbjegavao zlo. ${ }^{82}$ Savjest je svetište u kojem je čovjek sam s Bogom, čovjek treba slušati Božji zakon. ${ }^{83}$ Slično govori i dokument Dignitatis Humanae (Dostojanstvo ljudske osobe) u broju 3 o zahtjevu božanskog zakona koji se očituje kroz

\footnotetext{
${ }^{76}$ Isto, str. 9.

77 Isto, str. 9.

${ }^{78}$ Isto, str. 10. U govoru o savjesti treba spomenuti i Kanta te njegovo određenje savjesti kao svijesti koja je dužnost za samu sebe, a to razrađuje u Religiji unutar granica pukog uma, jednom od temeljnih djela filozofije religije.

${ }^{79}$ Isto, str. 10.

${ }^{80}$ Isto, str. 9.

${ }^{81}$ Isto, str. 9.

${ }^{82}$ DRUGI VATIKANSKI KONCIL, Pastoralna konstitucija o Crkvi u suvremenom svijetu, Gaudium et spes = GS, KS, Zagreb, 1980., br. 16.

${ }^{83}$ GS, br. 16.
} 
savjest, kao i zakon da se ljubi Boga i bližnjeg. ${ }^{84}$ Bog obvezuje čovjeka, ali ga ne sili i čovjek ne može djelovati protiv savjesti. ${ }^{85}$

Upravo $u$ ostvarenju vlastite slobode i kroz to ostvarenje te s njom u bitnome povezano savješću osoba postaje svjesna same sebe, svog svijeta i na neki način biva prisutna $u$ percepciji svojeg postojanja. To nas pak vodi, prema Welteu, k oslobađanju ili čišćenju postojanja. Postajemo svjesni ljudi oko sebe, prostora, objekata i tehničkih uređaja. Svijet je u isto vrijeme sve ono što vidim, čujem, ali i ono što mislim te ono čega se prisjećam. Čak i ono potiho izgovoreno, ono za čime težim ili čega se bojim - sve to je postojeće, ali zasjenjeno tim svjetlom čistine postojanja. Zato Welte kaže kako je za to čišćenje koje vodi preko odlučnosti k slobodi, odnosno od odlučnosti (hrabrosti) za slobodu, sposoban samo čovjek, osoba u kojoj je egzistencija prisutna na posebniji način. Posebniji spram svih ostalih živih bića. Osoba se, što je i očito, otvara tome postojanju na način koji je pripadan samo ljudskim bićima. Mogućnosti su postojanja pritom različite, ali neživa bića razumljivo ne mogu čuti i vidjeti, misliti i razumjeti kao čovjek. Stoga, nastavlja Welte, takva bića ne mogu zamijetiti, pogotovo ne reflektirati nad svojim postojanjem, kako je to moguće čovjeku. ${ }^{86}$ Ona su jednostavno složena, odnosno konstituirana da pohranjuju informacije u tehničkom smislu te ih zatim procesuiraju prema točno utvrđenim, unaprijed zadanim obrascima, dakle determinirano. Životinje su, koliko god pojedinim aspektima sposobnije od čovjeka, zarobljene u svijet determiniranih procesa.

S obzirom na pitanja o slobodi, (samo)svijesti i savjesti te konačno o duši, empirijski, to jest strogo znanstveni put i metode ovdje će biti malo od pomoći. Welte, dakako, ne isključuje pomoć (pozitivnih) znanosti poput, u ovom slučaju, biomedicine, kemije, biologije. Potonje se bave biokemijskim procesima u čovjeku i životinjama i to, dakako, vrlo uspješno. Njegov je odnos dakle prema znanosti i znanstvenom pristupu općenito i nadaleko poznat te ga on prihvaća i uvažava, no s bitnom pretpostavkom ispravnog uvažavanja i ingerencije nad pojedinim područjima. Jer ono što pozitivna znanost ne može dokazati (duša, sloboda) ne znači da im se može, sasvim olako, oduzeti kategorija postojanja, a upravo se redovito čini. Empirijska se znanost uzima apsolutnom i dovršenom te kao zadnji pravorijek (i) u ovim pitanjima, što je očita pogreška.

\footnotetext{
${ }^{84}$ DRUGI VATIKANSKI KONCIL, Deklaracija Dignitatis Humanae ( = DH) ili o vjerskoj slobodi, KS, Zagreb, 2002., br. 3.

${ }^{85}$ Isto, br. 2 i 3.

${ }^{86}$ Usp. WELTE B., Gesammelte Schriften I/1 Person, str. 27.
} 


\subsection{Sloboda i čovjekova duhovna priroda}

Sloboda je stvarnost koju osoba može potvrditi i preuzeti, mogu se odreći sebe i pokušati promijeniti svoju prirodu - a u svim tim pokušajima i analogijama pojavljuje se ista pojava - a to je, prema Welteu, ,ponašanje ponašanja“. Ovaj se pojam odnosi na čovjekovu cjelokupnu prirodu ili na odrednice njegove prirode $s$ obzirom na djelatnosti, to jest ponašanja, koje nisu ništa drugo do očitovanje te iste (čovjekove) prirode. Jer on ne može drugačije nego djelovati po načelu vlastite prirodnosti. Svakako se čovjekova prirodnost ne može promatrati izvan okvira čitave prirodnosti. Ponašanje je stoga, reći će Welte, nešto što se uvijek događa jer se ljudi ponašaju i u odnosu na cjelokupnu prirodu. ${ }^{87}$ Mjesto odakle se ljudi ponašaju prema svojoj prirodi može biti izvan ili iznad njihove prirode, ali ipak uvijek unutar (ogromnog) prostora čišćenja postojanja. Pojam čišćenja postojanja biva utoliko važan jer je to put koji vodi, prema freiburškom filozofu, k ostvarenju istinske slobode gdje se u perspektivi (samo)refleksije promišlja i premišlja vlastito ponašanje, svojstva, osobine i sve drugo što ulazi u djelatnosti, kako unutarnje - namjera, htijenja..., tako vanjske - govor, čini i dr. To su trenutci koji se suprotstavljaju ukupnosti nagona i drugih elemenata prirode, stoga pripada vlastitom redu, to jest odnosi se na poredak unutar vlastite prirode (samoodrživo ponašanje). Ljudsko ponašanje sadrži u sebi prirodne sklonosti ili odbojnost - tendencija za određivanje vlastita ponašanja. Zato nam je važan (već spomenut) pojam odlučnosti za slobodu koja pokreće, usmjerava itd. te koja je u izvjesnom smislu manifestacija same volje kao, u kantovskom smislu riječi, duhovne snage.

Naznačena prirodnost o kojoj se ovdje u kontekstu slobode i odlučnosti govori ukazuje na ono što Welte uvijek i iznova naglašava pojmovima odlučnosti za slobodu, odnosno o slobodi općenito koja treba biti (tek) izborena. Naime, koliko god se smatrali neovisnima u našim aktivnostima ili odlukama, uvijek postoji sklonost, odnosno težnje, nagnuća k nečem sekundarnom. Poanta je što će od svega spomenutog preuzeti dominaciju nad našom voljom. Tako volja, dosada osobito nerazmatrana, u odnosu na slobodu igra krucijalnu ulogu. Po volji se sloboda aktualizira, biva na djelu. Nema čiste, teorijske slobode. Pa čak i kada se radi o unutarnjem području, volja nas pokreće da nešto želimo ili pak ljubimo u specifično ljudskom smislu. Ona zapravo u pravom smislu riječi aktuira slobodu. Slično kao i kod slobode, za volju možemo reći da nije nešto fiktivno u nama, pogotovo ne konstrukt. U prilog iznesenoj tvrdnji i realnosti (volje) ide upravo doživljaj koji je sasvim realan i stvaran, u kojem jasno uočavamo uzrokovanja s obzirom na volju. Naime, težnje, nagnuća, konačno želje, kao jasni i

\footnotetext{
${ }^{87}$ Usp. Isto, str. 65-70.
} 
sasvim „učinkoviti“ entiteti u nama do svojeg ostvarenja, odnosno aktuiranja, dolaze tek po volji. Slično kao i sa slobodom. U tom smislu, oslanjajući se na Kanta, možemo ustvrditi da je volja, kao i sloboda, realnost na koju računamo i posredstvom koje zapravo djelujemo, bilo u aktivnom smislu, bilo u pasivnom - ustezanje, to jest propuštanje nekog djela.

Elementi se slobode, reći će Welte, ne pojavljuju u samo-regulirajućem samoponašanju bitka na jednom, već su to elementi mnogostruke odlučnosti. ${ }^{88}$ Odlučnosti u smislu opredjeljenja osobe za nešto. Postoje, naime, elementi koji određuju naše ponašanje bez da ga određujemo. To se odnosi na naše svakodnevno ponašanje gdje smo uvijek određeni onim što vidimo ili čujemo, znamo ili mislimo itd. Osoba biva određena uvjetima stvarnosti u kojoj živi i postoji, napose se ovdje misli na ljudsku okolinu i okoliš u kojem živimo. Sve to određuje kakvo će biti ljudsko ponašanje i utječe na ponašanje osobe. Naš svijet u cjelini i sve ono što ga određuje dolazi u tome do izražaja te se pojavljuje u službi već spomenutog osvjetljavanja našeg postojanja. To pak dalje znači da nismo birali svijet u kojem ćemo živjeti, ali smo sposobni nešto promijeniti u smislu vlastita ponašanja, pridonijeti našoj slobodi ${ }^{89}$ i živjeti tako puninu svog bivstva.

O pojmu osobe i pripadne joj slobode govorilo se mnogo tijekom povijesti filozofije. Filozofska rasprava o ljudskoj osobi vrlo je aktualna i živa i u današnje vrijeme. Još od Aristotela ljudska osoba biva označena kao društveno biće koje je svakodnevno u interakciji s drugim osobama živeći s njima u zajednici. Uz filozofiju i mnoge druge znanosti progovaraju o čovjeku kao osobi te promatraju i donose određena ograničenja s kojima se ona susreće na putu ostvarenja svoje slobode. Stoga kako bi osoba ostvarila puni potencijal svoje osobne slobode, cjelokupno ponašanje osobe $s$ jedne te sloboda i jastvo $s$ druge strane uvijek idu zajedno i tako ih treba i promatrati te razumijevati. Boško Pešić će pisati o Augustinu kao rodonačelniku ideje o slobodi gdje Augustin iz uočavanja neraskidive povezanosti $\mathrm{s}$ racionalnim raspolaganjem vlastitim htijenjem donosi samosvojan koncept liberum arbitrium, vrhunske voljne mogućnosti da čovjek sebe održi slobodnim od svih izazova grijeha. ${ }^{90}$

\footnotetext{
${ }^{88}$ Usp. Isto, str. 37-38.

${ }^{89}$ U tom kontekstu Welte prilikom tumačenja pojma slobode spominje Sigmunda Freuda. Prema Freudu, jedino istina oslobađa čovjeka. Freud će ustvrditi kako se liječnik duše bavi istim problemima kao i filozofija i teologija - dušom čovjeka i njegovim liječenjem. Još jedan Welteov suvremenik kojeg je iznimno cijenio jest Jung. On je religiozno iskustvo povezao s određenom vrstom emocionalnog iskustva - prepuštanjem višoj sili, bez obzira na to zvala se ta viša sila Bog ili nesvjesno. To je Jungov koncept religije. I u Weltea je čovjek čitav život u traganju za istinom koja će ga osloboditi u smislu da njom stječe smisao vlastitog postojanja.

${ }^{90}$ PEŠIĆ B., Uz temu Filozofija slobode - izabrani problemi, u: Filozofska istraživanja, 41 (2021) 1, str. 3-4.
} 
Jean Paul Sartre će u drugom kontekstu reći da je čovjek „osuđen na slobodu, jer kada je već bačen u svijet, odgovoran je za sve što radi“91; u nama je egzistencijalna nužnost koja nas ne prepušta bilo kakvoj proizvoljnosti, nego nas sili da afirmiramo nešto i da istim činom koafirmiramo sebe autorealizirajući svoju svijest. ${ }^{92}$ Naravno, ovdje treba reći kako je Sartreovo razumijevanje slobode isključivo neteologijsko i antireligijsko jer Sartre gradi slobodu iz „ništa“ koje se opire kršćanskom razumijevanju. No ako se vratimo onom što je Welteovo poimanje slobode htjelo reći, možemo se izraziti Kušarovim riječima: „srž mojega bića sačinjava jedan polet koji nezaustavno i nesuzdrživo hrli od nesvjesnog stanja k slobodnoj samosvijesti““.93

I, zaključno, povratak religiji i onom Vječnom, prema Welteu, može dovesti osobu do istinskog življenja slobode u punini smislenosti i svrhovitosti svog vlastitog života.

\subsection{Ljudsko dostojanstvo u okviru Welteova govora o slobodi}

Danas je posebno vidljivo kako se situacija vezana uz ljudsko dostojanstvo i s tim vezana ljudska prava iz korijena mijenja. To je zahtjev, kako Welte u svom govoru o slobodi kaže, za samoodređenjem i samoostvarenjem koji se oslikava u čežnji za slobodom i identitetom, kao i u zahtjevu za pravdom, mirom i tolerancijom među ljudima. Kada se radi o dostojanstvu ljudske osobe, treba reći kako je to u osnovi pitanje kršćanske antropologije gdje se posebno ističe jedna od temeljnih biblijsko-kršćanskih istina -da je čovjek slika Božja. Na toj temeljnoj istini počiva dostojanstvo čovjeka kao osobe.

Instrukcija Kongregacije za nauk vjere Dignitas personae (Dostojanstvo osobe) na poseban način naglašava da dostojanstvo treba biti priznato svakom ljudskom biću od začeća do prirodne smrti. ${ }^{94} \mathrm{U}$ tom smislu, kako i Welte pomalo kantovski prožeto ističe, osoba nikad ne smije biti korištena ili iskorištena kao svrha za postizanje bilo kakvih ciljeva, bilo društvenih, bilo političkih. Kantovo poimanje vjere bitno je vezano uz moralno-praktičnu dimenziju ljudskog života. Vjera je čovjekov u slobodi ukorijenjen egzistencijalni stav kojim se on odnosi prema transcendentnom i ujedno realizira samog sebe $u$ vidu postizanja svoje

\footnotetext{
${ }^{91}$ AKRAP A., Susret - otkrivanje bitka, u: Služba Božja, 44 (2004) 4., str. 9.

92 KUŠAR S., Filozofija o Bogu, KS, Zagreb, 2001., str. 44.

${ }^{93}$ Isto, str. 44.

94 KONGREGACIJA ZA NAUK VJERE, Naputak o nekim bioetičkim pitanjima, Dignitas personae (Dostojanstvo života), KS, Zagreb, 2009., br. 7.
} 
konačne svrhe - najvišeg dobra kao sklada blaženstva u razmjeru s moralnošću. ${ }^{95}$ No, vezano uz Kanta, treba reći sljedeće kada se radi o slobodi i volji koju čovjek posjeduje:

„Tako dakle svaki čovjek ima empirijski karakter svoje volje koji nije ništa drugo nego određen kauzalitet njegova uma, ukoliko ovaj u svojim djelovanjima pokazuje neko pravilo prema kojemu se umski razlozi i njihova djelovanja mogu razabrati prema svojoj vrsti i svojim stupnjevima i prosuditi subjektivna načela njegove volje. Budući da sam taj empirijski karakter moramo izvesti iz pojava kao djelovanja i iz njegova pravila koja daje iskustvo, sva su djelovanja čovjeka u pojavi određena njegovim empirijskim karakterom i drugim sudjelatnim uzrocima prema poretku prirode. Kad bismo pak sve pojave njegove volje mogli istražiti do temelja, onda ne bi bilo ni jednoga jedinog ljudskog čina koji ne bismo mogli sigurno unaprijed proreći i na osnovi njegovih prethodnih uvjeta spoznati, da je nužan. S obzirom na ovaj empirijski karakter nema dakle slobode, pa ipak mi samo na osnovi empirijskoga karaktera možemo promatrati čovjeka, ukoliko samo razmatramo, i htjeti da fiziologijski ispitamo motive njegovih djelovanja, kao što se to događa u antropologiji.“96

U Kanta je stoga Bog isključivo regulativna ideja uma i predstavlja spoznajni moment transcendencije o kojem ne možemo znati ništa. To su ona pitanja (Bog, besmrtnost duše, svijet - je li konačan ili ne ) kod kojih bi um, kada bi želio dati odgovor, zapao bi u proturječja i opet ne bi došlo do odgovora.

Tako u moralno-praktičnom vidiku shvaćena vjera nije neki bijedni ostatak smrvljene metafizike, kako Welte rezolutno ističe, koji bi bio previše za filozofiju, a premalo za religiju, nego je to način kako razumsko biće u svijetu autentično opstoji i djeluje u nadi u postignuće svoje konačne svrhe. ${ }^{97}$

Spomenuta deklaracija Dignitatis humanae, ili o vjerskoj slobodi, govori o pravu osobe i zajednice na društvenu i građansku te posebno vjersku slobodu. Na početku ove deklaracije stoji sljedeće: „Dostojanstvo ljudske osobe u ovo naše doba iz dana u dan sve više prodire u svijest ljudi, i raste broj onih koji zahtijevaju da ljudi mogu imati i služiti se vlastitom odlukom i odgovornom slobodom u svom djelovanju, ne pod pritiskom, nego svjesni svoje dužnosti. Isto tako zahtijevaju da se javnoj vlasti postave pravne granice kako se ne bi previše sužavala područja časne slobode bilo da se radi o pojedincima ili zajednicama. Ta se potreba slobode u društvu najviše odnosi na dobra ljudskog duha, u prvom redu na ono što se tiče slobodnog ispovijedanja religije." ${ }^{\text {(98 }}$ Priznavanje dostojanstva svakom ljudskom biću izriče veliko »da« ljudskom životu i valja ga kroz tu prizmu i razumijevati te prihvaćati i cijeniti, u ,zgodno ili nezgodno vrijeme“, odnosno neovisno o povijesno-društvenim

\footnotetext{
${ }^{95}$ KUŠAR S., Pojam vjere u Kantovoj filozofiji religije, u: Prolegomena, 13 (2014) 1, str. 59-84.

${ }^{96}$ KANT I., Kritika čistog uma, prev. Sonnenfeld V. D., Nakladni zavod Matice hrvatske, Zagreb, 1984., str. 257.

${ }^{97}$ KUŠAR S., Pojam vjere u Kantovoj filozofiji religije, str. 59-84.

${ }^{98}$ DRUGI VATIKANSKI KONCIL, DH, Uvod, str. 1.
} 
zbivanjima. U tom je kontekstu korisno još jednom spomenuti Pastoralnu konstituciju o Crkvi u suvremenom svijetu, Gaudium et spes, u kojoj stoji sljedeće: „Danas čovječanstvo proživljava novo razdoblje svoje povijesti, u kojemu se duboke i brze promjene postupno proširuju na cijeli svijet. One su proizišle iz čovjekove inteligencije i stvaralaštva, povratno djeluju na samog čovjeka, na njegove individualne i kolektivne sudove i želje, na njegov način mišljenja i djelovanja što se tiče stvari i ljudi.“99 Važno je napomenuti da spomenuta konstitucija ističe kako ljudska prava mora štiti društvena zajednica, počevši ponajprije od same konkretne države te drugih transnacionalnih i zajednica i institucija. ${ }^{100}$

Upravo se na to referira Welte kada razrađuje pojam osobe i ljudskog dostojanstva te kada uz pojam osobe usko vezuje pojmove slobode, odlučivanja, stvaralaštva i samoostvarenja, pri čemu navedene danosti čovjek može razvijati jedino u „slobodnom“ okružju. Uz spomenutu slobodu i odlučnost iznimno se zanimljivim tako pokazuje Welteovo isticanje drugih dviju karakteristika - stvaralaštva i samoostvarenja - u kontekstu njegove razradbe o osobi. Prvo na što nas netom navedeni pojmovi upućuju jest svojevrsna inteligencija kao dar i sposobnost. Iza određene inteligencije, koje je osoba u manjoj ili većoj mjeri nositelj, ona se, osim puke psihološke konstatacije o ,sposobnosti snalaženja u prostoru“, zapravo najbolje očituje u pojmu kreativnosti. U tom smislu inteligenciji kao naravnoj danosti redovito u pozadini stoje dvije stvarnosti: s jedne strane to je otvoren, slobodan um te $\mathrm{s}$ druge maštovit i kreativan um. Obje su dimenzije čovjekove umske sposobnosti potrebne da bi osoba svoje svakodnevne postupke i htijenja uskladila s jednom opravdanom razložnošću, tražeći te u isto vrijeme otkrivajući kako svrhu i utemeljenost vlastitih, pojedinačnih čina, tako i posljedično svrhu, odnosno smisao cjelokupnog života. Time dolazimo do naizgled jednog paradoksa, pri čemu bi za otkrivanje smisla života čovjek nužno trebao kreativnost, što u konačnici upućuje na nešto, istina, vrijedno, no pomalo proizvoljno. Ipak, i kao svojevrsni mogući odgovor možemo s Welteom, a u svrhu obrane veze inteligencije (kreativnosti) i smisla, reći da navedeni aspekti (umskog) traganja za smislom stoje u pozadini onog što on označava pojmovima samoodređenja i samoostvarenja. Smisao (života) nije tek tako i olako dan. Za njega se čovjek mora izboriti, odgovorima na mnoštvo, pa i teško prihvatljivih pitanja, poput onih o smislu zla i patnje. Navedene stvarnosti u konačnici, uz slobodu, zrcale i ljudsko dostojanstvo.

\footnotetext{
${ }^{99}$ DRUGI VATIKANSKI KONCIL, GS, br. 4.

${ }^{100}$ Isto, br. 75.
} 
Da ljudsko dostojanstvo nije tek izručeno na milost i nemilost državnim zajednicama, pokazuje nam se i kroz zahtjev njihova institucionalnog legitimiranja, odnosno i jasnije, kroz instituciju ljudskih prava kojima naš autor u ovom kontekstu daje iznimno važno značenje. Prema Welteu, u čovjeka je duboko utkana čežnja za slobodom i identitetom te samim time svojevrsna osjetljivost u pogledu vlastita dostojanstva. Svijest vlastitog dostojanstva pomaže čovjeku u otkrivanju i potvrdi njegove jedinstvenosti i neponovljivosti, ponajprije njemu samom, a zatim i drugima. Ova se neponovljivost i jedinstvenost ne sastoji tek u sposobnosti ili uspjehu u ovom ili onom području. Ona se očituje u tome što je čovjek ljudsko biće i upravo mu na temelju toga pripadaju neotuđiva prava povezana sa slobodom $\mathrm{u}$ govoru $\mathrm{i}$ djelovanju. Naše je dostojanstvo dakle na djelu, to jest ono se poštuje polazeći od neotuđivog prava da nastupamo razumski i slobodno, da shodno svojim svjetonazorskim i svakim drugim uvjerenjima tražimo i pronalazimo smisao vlastitog života. Ovdje se bitnim pokazuje odnos spram samog sebe, pa će tako Welte reći za ovaj odnos kako ti „osvijetljeni pokreti egzistencije proizlaze iz njih samih i tiču se njih samih, oni reflektiraju svoj odnos prema samome sebi“. ${ }^{101}$ Dia-logos duše sa samom osobom za našeg se autora pokazuje nemimoilaznim načelom življenja uopće. Iz tog se dijaloga pak nadolazi na ono što je više od njega. U tom smislu, prema njemu, sami temelji ljudskog života bivaju povezani s onim što je više, veće od čovjeka, to jest s vječnim, odnosno s Bogom koji je, kako više puta naglašeno, za čovjeka vjernika temeljni smisao življenja te iskonski temelj same religije.

Nijedan čovjek na tom putu traganja za samim sobom i osvjetljavanja svojeg vlastitog postojanja i dostojanstva koje mu pripada ne može zaobići ova pitanja koja su moralne prirode, ali jedina vode $\mathrm{k}$ tome da osoba dobije potvrdu svog vlastita dostojanstva $\mathrm{i}$ dostojanstva onih s kojima živi. Ovo su pitanja koja obilježavaju čovjekovu opstojnost $\mathrm{i}$ određuju njegov položaj u svijetu, a kršćanin, prema Welteu, jest onaj koji odgovor na sva ta pitanja pronalazi u vjeri te posljedično u njezinu prakticiranju u kultu u kojem se za vjernika očituje živi božanski Bog. Življenje te prakticiranje vjere na tragu kršćanstva, točnije njezina katoličkog kulta, zrcali - prema Welteu - božanskog Boga koji nam po objavljenoj Istini, Isusu Kristu i njegovoj Crkvi, daje odgovor na iskonsku čežnju za smislom i konačnim ciljem našeg života. ${ }^{102}$ Odgovor na sva ta pitanja koja pridonose ostvarenju slobode i čovjeku pripadnog dostojanstva Welte naziva humaniziranjem svijeta u kojem živimo. ${ }^{103}$ To bi pak značilo da treba pobijediti globalnu ravnodušnost i dokinuti svaki vid čovjekove apstraktnosti

\footnotetext{
${ }^{101}$ Usp. WELTE B., Gesammelte Schriften I/1 Person, str. 37-38.

102 Usp. Isto, str. 212-227.

${ }^{103}$ Usp. Isto, str. 121.
} 
te pogled ne usmjeravati samo prema budućnosti, nego smisleno oblikovati sadašnjost kako bi budućnost bila osvijetljena samim čovjekovim prisustvom, njegovom slobodom i već spomenutim dostojanstvom, koji ga pak u konačnici vode do Cilja iz kojeg sve izvire, ali na kraju i uvire - Boga.

Konačno, u pogledu humanuma Welte se ne zadržava tek na (kršć.) religiji i njezinu „življenju“, već ono za njega pretpostavlja sve ono što je specifično ljudskog duha, odnosno plod ljudskog duha, poput čitave kulture, to jest kulturnog nasljeđa u koje su uključene i znanost i umjetnost zajedno. To Welte naziva „istinski humanum“ koji prvotno biva povezan sa slobodom kao odrednicom čovjeka kao osobe - tek kao slobodno i racionalno biće čovjek stvara sve navedeno, međutim, uz nju su tu još i moralnost, savjest, pravednost - moralne kvalitete koje navedeno uz religiju nužno oplemenjuju. Svako njihovo isključivanje značilo bi osuđivanje čovjeka i njegove čovječnosti, što bi pak imalo za posljedicu stavljanje u pitanje cjelokupnog čovjekova postojanja. ${ }^{104}$

\section{Nada u Welteovoj fenomenologiji religije}

\subsection{Fenomenologija nade i njezina važnost za ljudsko postojanje}

Vrlo bitna tema kojom se Welte bavio u svojem promišljanju o osobi jest pojam nade. ${ }^{105}$ Nada je vrlina koju je Welte usko vezao uz fenomen postojanja s jedne strane te uz fenomen straha s druge strane. Oba su ta fenomena usko vezana uz čovjekovo bivstvovanje. Kao kršćanin, čovjek o nadi, reći će Welte, može uvijek razmišljati u dvostrukom smislu: prvo, kao nešto sebi vlastito, pripadno bitno usađeno u njega jer nada jest oduvijek u čovjeku, ona postoji u čovjeku; drugo, ta ista nada budi određeni strah u čovjeku, strah pred nečim s čim se još nije susreo, ali što iščekuje i što želi ostvariti. ${ }^{106}$ Nada proizlazi iz naše ljudske prirode, ona je čovjeku kao biću trajnog nastojanja i hoda prema nekom cilju urođena poput mogućnosti govora. Posebnu ulogu igra pojam nade u crkvenim dokumentima, kao i samom Evanđelju. Welte u svojim razmatranjima pak posebno spominje sinodski dokument pod nazivom Naša nada, koji je bio tema 85. njemačkog katoličkog dana. ${ }^{107}$ Zaključak toga dokumenta i ono o čemu se razgovaralo na tom, za njemačke katolike iznimno važnom

\footnotetext{
${ }^{104}$ Usp. Isto, str. 19.

${ }^{105}$ Usp. WELTE B., Dasein als Hoffnung und Angst (1982.), u: Bernhard Welte, Gesammelte Schriften I/I Person, Herder, Freiburg-Basel-Wien, 2006., str. 228.

${ }^{106}$ Usp. Isto, str. 228.

${ }^{107}$ Usp. Isto, str. 229.
} 
događaju, kako ga Welte ocjenjuje, jest upravo nada kao ona bogoslovna ulivena vrlina koja u bitnome utječe na naš život i posebno karakter te usmjerava naše postojanje. Istovremeno taj dokument pokazuje i određenu dozu zabrinutosti za ljudski život u modernom svijetu. Poanta je u svojevrsnom otuđenju suvremenog, poglavito urbanog čovjeka, koji je izgubio smisao i, štoviše, volju za ovu vrlinu. Nada se, pa čak i u svojem ne-teološkom smislu, ne može miješati s optimizmom, odnosno sa svojevrsnim radosnim iščekivanjem budućnosti. Ona u bitnome uključuje vjeru prožetu čežnjom te, što je vrlo važno, iskustvo svojevrsne anticipacije. Tim više dolazi upravo ovaj aspekt do izražaja kada se radi o kršćanskoj nadi: obećanje nije tek prazna utjeha koju nam daju drugi ili koju pak dajemo sami sebi. Ono se u bitnome tiče Onoga koji je povrh nas i koji jedini može na istinski način obećati - Boga.

Kada se tako radi o pojmu nade, Welte se posebno referirao i spominjao autore poput E. Blocha, J. Moltmanna i T. Akvinskog. ${ }^{108}$ Za prvog u nizu, Ernsta Blocha, nada predstavlja određeno buđenje našeg modernog postojanja. ${ }^{109} \mathrm{U}$ djelu Princip nada E. Bloch razvija marksističku ontologiju još-ne-bitka. ${ }^{110}$ Tako Bloch povezuje židovsko-mesijansku i kršćansku tradiciju apokaliptike te hilijastičke ideje pomoću kojih konstruira utopiju oslobođenog čovječanstva. ${ }^{111}$ Pojam „nade“ se u Blocha iščitava upravo u onom »još-ne« trenutku gdje ona postoji kao mogućnost koju tek treba ostvariti. U takvom poimanju nade uvijek postoji zahtjev za njezinim konkretnim ozbiljenjem. Pojam »nade« Bloch uvijek povezuje s konkretnim djelovanjem, s praksom, što je naravno rezultat okruženja i misli koju je zagovarao i vjerovao. Da bi se nada doista i ostvarila, potrebno je planiranje i djelovanje kako bi se pokazalo ono ,još-ne-izašlo na vidjelo u čovjeku, i s nutarnje strane njegova svijeta“. ${ }^{112}$ Slično kao i kod ukazivanja na slobodu, svijest itd., tako i kod pojma nade zadobiva čovjekova nutarnja, duhovna dimenzija iznimno na važnosti jer se slično kao i kod spomenutih pojmova ona drži kao stvarnost pripadna čovjeku. Zašto se Bloch ovdje čini Welteu zanimljivim? On sjedinjuje paradoksalnost koja prati pojedine neomarksističke mislioce: nastojeći, naime, ostati vjerni marksističkoj ideji, oni ostaju, barem deklarativno, uz ateizam i socijalistički model društvene zajednice, međutim, s druge se strane iznimno nadahnjuju na religioznim motivima židovske i kršćanske misli, ovdje u pogledu nade. Upravo to dakle čini Bloch u koncipiranju svoje ideje o pojmu nade. On stvarnost nade, istina,

\footnotetext{
${ }^{108}$ Usp. Isto, str. 231.

${ }^{109}$ Usp. Isto, str. 228.

${ }^{110}$ Usp. BLOCH E., Princip nada I, prev. Šarinić H., Naprijed, Zagreb, 1981., str. 25.

${ }^{111}$ Usp. JUNG W., Hoffnung, u: PRECHTL P. und BURKARD F. P., Metzler Philosophie Lexikon. Begriffe und Definitionen, Verlag J. B. Metzler, Stuttgart - Weimar, 1996., str. 216-217.

${ }^{112}$ Usp. BLOCH E., Ateizam u Kršćanstvu, str. 252.
} 
utemeljenje u modernom ateizmu pri čemu hod prema budućnosti svoj vrhunac dostiže slijedom ateističke misli. Međutim, $\mathrm{u}$ isto vrijeme Bloch isključuje radikalni, pogotovo pomodarski militantni ateizam (danas osobito prepoznatljiv u misli Richarda Dawkinsa), već u svojem načelu nade nudi utopijsko-apokaliptička stremljenja radikalnog zaokreta prema ispunjenoj i sretnoj budućnosti (jasno bez Transcendencije) slično židovstvu i kršćanstvu. Budućnost ispunjena smislom te anticipiranje na njoj već sada odlike su Blochove koncepcije nade te ateizma uopće. ${ }^{113}$

$\mathrm{S}$ dužnim poštovanjem prema autoru s kojim ne dijeli svjetonazor, Welte u Blochu uočava zahtjev i time poziv humanijeg pristupa čovjeku, pri čemu naš autor - što svjesno, što nesvjesno - daje nacrt jednog mogućeg dijaloga s ateizmom. Iako se nada uvijek suočava $\mathrm{s}$ granicama onog ljudskog što je u čovjeku, te usprkos svim njegovim ograničenjima, nada nosi čovjekovo ispunjenje za smislenom budućnošću. Nada znači uvijek živjeti u napetosti prema nečem, prema nekom ostvarenju, tu čovjek kao osoba nikaa nije na gubitku.

Drugi autor kojeg Welte spominje i koji mu je bio posebno zanimljiv po pitanju poimanja „nade“ jest Jürgen Moltmann. Pojam nade za Moltmanna bio je također iznimno važan. Njegovo ključno djelo upravo je Teologija nade i u tom je smislu upravo »nada« pojam od kojeg Moltmann polazi i s kojim završava. Moltmann je jedan od prvih europskih teologa koji je pokušao gledati na križ i uskrsnuće Isusa Krista te ih shvaćati u okvirima njegova povijesno-zemaljskog života. ${ }^{114} \mathrm{Za}$ razliku od Blocha, polazište Moltmannova promišljanja o nadi jest Bog te se za ovog njemačkog teologa nada temelji na vjernosti Bogu koji je uskrisio Isusa Krista od mrtvih te je upravo Krist taj koji predstavlja nadu za sve ljude. ${ }^{115} \mathrm{U}$ tom je smislu Isus Krist paradigma onog koji se nada, odnosno pouzdanje u Božje providonosno vodstvo, pa makar ono bilo i kroz patnju. Valja istaknuti kako je netom spomenuti autor Ernst Bloch svojim djelom Princip nade utjecao i na Moltmanna te mu dao poticaj za razmišljanje o kršćanskoj vjeri u perspektivi nade. ${ }^{116}$ Možemo se složiti s I. Karlićem koji ističe kako je ,vrijednost Moltmannova djela upravo u tome što on ne zaboravlja probleme koji muče današnji svijet i čovjeka te svojim djelovanjem želi ponuditi

\footnotetext{
${ }^{113}$ Usp. KARLIĆ I., Teološki put Jürgena Moltmanna, u: Diacovensia, 25 (2017) 4, str. 639-653.

${ }^{114}$ Usp. GROZDANOV Z., Teološki put J. Moltmanna, u: Z. Grozdanov (ur.), Bog pred Križem, Zbornik u čast J. Moltmanna, Rijeka, 2007., str. 211-231.

${ }^{115}$ Usp. GROZDANOV Z., Teološki put J. Moltmanna, str. 211-231.

${ }^{116}$ Usp. KARLIĆ I., Teološki put Jürgena Moltmanna, str. 643.
} 
uvjete za opći boljitak i to u odnosu između čovjeka i Boga, te svekolikog čovječanstva i Boga" 117

Konačno, za Weltea se u razmatranju bogoslovske vrline nade nezamjenjivim pokazuje Toma Akvinski. O nadi skolastički učitelj kaže sljedeće: „Nada dolazi od Boga i čovjeka vodi prema beskrajnom dobru, a to je vječni život koji se sastoji u uživanju samoga Boga“. ${ }^{118}$ Toma promatra pojam nade dvostruko: s jedne strane kao naravno čuvstvo koje se odnosi na ostvarenje nekog teško dostižnog dobrog cilja u budućnosti te s druge strane nadu promatra kao nadnaravnu krepost koja čovjeka osposobljava za postizanje vječne sreće koja bi mu se, da nije nadnaravna krepost, činila nedostižnom. ${ }^{119}$ Za Tomu prednost ima nada koja potječe od Boga i koja vodi čovjeka k Bogu, a sve one druge nade koje bi se odnosile na postizanje nekih osobnih (zemaljskih) ciljeva bivaju smislene i prihvatljive samo u slučaju da vode prema tom glavnom cilju nade koji je prema Tomi samo Bog. ${ }^{120}$ Ovo poimanje nade koja bi bila usmjerena samo na postizanje ovozemaljskih čovjekovih ciljeva posljedica je, prema Tomi, čovjekove osobne konačnosti i nju osoba treba prevladati kako bi došla bliže k onoj vječnoj nadi - koja je u Bogu. ${ }^{121}$

Na tragu kršćansko-tomističkog poimanja nade, koji njoj daje bitno transcendentni pečat, držimo vrijednim ovdje spomenuti i Josepha Piepera, kršćanskog teologa i filozofa kojem je pojam nade upravo u tom smislu iznimno blizak. Pieper nadu shvaća kao vrlinu (krijepost) koja je uzvišenje ljudske osobe u njezinoj biti. ${ }^{122}$ On pojam nade obrađuje na tomističkoj liniji, razlikujući „status viatoris“ i „status comprehensoris“ kao pra-načine bitka svih stvorenja, a poglavito čovjeka. ${ }^{123}$ Čovjek kao viator nalazi se na putu prema sreći $\mathrm{i}$ blaženstvu cijeli svoj život sve do smrti, dok homo comprehensor tek poslije smrti prelazi u stanje posjedovanja sreće koja se sastoji u gledanju Boga. ${ }^{124}$ Zaključno na Welteovu tragu možemo reći kako upravo čovjekov rad na sebi i samoostvarenje, isključujući pritom sebeljublje ili ostvarenje, istinskog čovjeka nedostojnih sebičnih interesa, odnosno koristi koje bi isključivale druge, jest put koji vodi $\mathrm{k}$ istinskom razumijevanju, a zatim i ostvarenju nade koja svoj izvor, zbog navedene nepatvorenosti i čistoće, ima jedino u onom Transcendentnom, to jest u Bogu.

\footnotetext{
${ }^{117}$ Usp. Isto, str. 652.

118 AKVINSKI T., Summa theologica, II-II, q. 17, a. 2.

${ }^{119}$ Usp. WELTE B., Gesammelte Schriften I/1 Person, str. 49.

${ }^{120}$ Usp. Isto, str. 49. i 81.

${ }^{121}$ Usp. Isto, str. 81.

122 Usp. PIEPER J., Über die Hoffnung, Kösel Verlag, München, 1949., str. 25.

${ }^{123}$ Usp. MALOVIĆ N., Ima li nade u današnjoj filozofiji?, u: Riječki teološki časopis, 16 (2008) 1, str. 65-80.

${ }^{124}$ Isto, str. 70.
} 


\section{4. »Strah« kao fenomen u Welteovu promišljanju o osobi}

\subsection{Novija filozofija i fenomen straha - uvodna razmatranja o strahu}

U novijoj su filozofiji o strahu posebno promišljali filozofi poput Hegela, Kierkegaarda i Heideggera. O književnika valja spomenuti F. Kafku kojeg je Welte često spominjao prilikom razmatranja ovog pojma. Za Hegela je strah uvijek „strah od nevidljivoga“", od apsolutne moći koja je suprotnost svijesti o vlastitoj (ne)moći. ${ }^{125}$ Strah je u Hegela i osjećaj nelagode koji ima pojedinac prilikom razmišljanja da će zapasti u neke nerješive (po)greške. ${ }^{126}$ Strah od istine, reći će Hegel, pojavljuje se ondje gdje pojedinac neumorno traga upravo za istinom. Taj, kako ga Hegel naziva, „nerazumni strah“ dalje rađa negativnim efektom ograničenja. ${ }^{127}$ Svojevrsna taština u vidu samodostatnosti pritom se pojavljuje kao racionalizacija tog straha, pri čemu je upravo ona uvjet ,pogledati strahu u oči“. Ona omogućuje dakle ,istinu o strahu“ jer je drugi način suočavanja s njim uzmicanje ili agresija. $^{128}$

Kada se radi o Kafki i njegovu suočavanju sa strahom, G. Kalašević ističe kako je potrebno najviše pažnje posvetiti njegovim autobiografskim djelima koja su usko vezana uz pojam straha te donose način na koji se može ophoditi spram tog fenomena te ga u konačnici i pobijediti. Kafka se pita: „Može li ono Neuništivo u čovjeku uništiti strah?“129 Kafkin cijeli život prožet je jednim velikim paradoksom, on je sam to više puta isticao ovim riječima: ne bojim se, ali me je strah. Kraj borbe sa strahom za Kafku je došao kada je teško obolio i kada mu je ubrizgana smrtonosna injekcija opijuma, na što je doslovno natjerao liječnika riječima: „Ubijte me - jer ćete inače postati ubojica!“ Bio je to kraj Kafkine dugogodišnje borbe sa strahom. Svi odnosi koje je on tijekom života pokušavao održati bili su duboko obilježeni njegovim neriješenim odnosom prema ocu, zbog kojeg je Kafka proživljavao duhovne bolove i strah. Strah je, prema Kafki, zapravo svakidašnja pojava u životu čovjeka koji nas ograničava u našoj slobodi. Strah je i reakcija na opasnost koja pretpostavlja mogućnost tjelesnog ili duševnog razaranja. On je nepozvani gost svake duše, međutim, u isto vrijeme on predstavlja pokušaj ponovnog uspostavljanja izgubljenog sklada u životu. U tom je smislu strah motivirajuć. Otuda i uvjerenje kako je strah svrhovit i pozitivan. ${ }^{130}$ Treba zasigurno

\footnotetext{
${ }^{125}$ Usp. KOPREK I., Filozofsko promišljanje o strahu, u: Strah - naš životni pratilac, (ur.), Valentin Pozaić, FTI - centar za bioetiku, Zagreb, 1995., str. 21.

${ }^{126}$ Usp. JEVTIĆ N., Iskušenje ironije. Može li ironija igrati ulogu kritike?, u: FI, 33 (2013) 2, str. 240.

${ }^{127}$ Usp. Isto, str. 240.

${ }^{128}$ Usp. Isto, str. 240.

${ }^{129}$ Usp. KALAŠEVIĆ G., Kafkino hrvanje sa strahom, filozofsko-teološki pokušaji, u: Počeci, 4 (2003) 1 , str. 6.

${ }^{130}$ Usp. Isto, str. 8-10.
} 
razlikovati vanjsku i unutrašnju dimenziju straha. Ona vanjska, može se reći, prevladana je svojevrsnim otklanjanjem od izvanjske neprijatne situacije, no ona unutrašnja mnogo je „opasnija“ i ozbiljnija jer je dio same čovjekove osobe i osobnosti. Misliti takav strah znači zapravo umnažati ga te ga često dovodi do ekstremnih granica gdje postaje nepodnošljiv i razara čovjeka koji ga misli.

Pojam straha i njemu posebno prirođene tjeskobe neodvojivi su od postulata $\mathrm{S}$. Kierkegaarda koji već i u samoj čovjekovoj mogućnosti djelovanja i njegovoj slobodi vidi razlog straha. Prema Kierkergaardu, razlog tomu je neuspjeh, odnosno opasnost da čovjeka njegovo vlastito djelovanje gurne u egzistencijalnu propast. ${ }^{131} \mathrm{U}$ većini je svojih djela Kierkegaard bio duboko opterećen i pogođen pitanjem straha i strašljivosti općenito. Kierkegaardovo djelo $I l i$ - ili sastoji se od neke vrste rasprave među osobama o stupnjevima mogućnosti postojanja: estetskom - koje je bezbožno i egocentrično, etičkom - koje je ispunjeno osjećajem dužnosti te religijskom kao najvišem - ispunjenem patnjom kao pripremom za vječnost. Navedena stanja Kierkergaard ocrtava u svjetlu svog stava da je čovjek biće mogućnosti, slobode i osobne odgovornosti za vlastitu sudbinu te da je tu odgovornost teško prihvatiti. ${ }^{132}$ Konačno, samo njegovo djelo Strah $i$ drhtanje govori o Božjoj zapovijedi i ideji žrtvovanja prikazanoj kroz priču o Abrahamu i njegovu sinu, pri čemu se, osim štovanja i pobožnosti prema Bogu, od čovjeka vjernika zahtijeva maksimalni vid preuzimanja odgovornosti, kao što je to pokazao sam Abraham. ${ }^{133}$ U djelu Pojam straha on promišlja o ulozi straha u poimanju grijeha. U religioznom, specifično Kierkergaardovu smislu općenito, strah može biti posljedica napuštanja ili kršenja Božjih zakona, posljedica narušavanja harmonije između Boga i čovjeka, odnosno posljedica samog grijeha. ${ }^{134}$ I u djelu Stupnjevi životnoga puta Kierkegaard se vraća raspravi o patnji razmatrajući ponovno navedene stupnjeve postojanja (estetički, etički i religiozni), pri čemu religiozni još jednom izdiže kao najviši, ali i najzahtjevniji. Konačno, strah proizlazi iz ljudskog položaja u kojem se sastaju vječno i vremenito. ${ }^{135}$

Kierkegaard traži u kršćanskoj vjeri putokaze k osvješćivanju neponovljive prirode pojedinca i njegova života kao izlaza iz stanja straha i tjeskobe. ${ }^{136}$ Čovjek nije istinski religiozan po tome što se pridržava izvanjskih zahtjeva vjere, nego po tome kada u samoj

\footnotetext{
${ }^{131}$ Usp. KIERKEGAARD S., Strah i drhtanje, Verbum, Split, 2001., str. 17.

132 Usp. KIERKEGAARD S., Ili - ili, prev. Milan Tabaković, Veselin Masleša, Sarajevo, 1990., str. 55.

${ }^{133}$ Usp. KIERKEGAARD S., Strah i drhtanje, str. 35.

${ }^{134}$ Usp. DUGANDŽIĆ I., Strah u svjetlu Biblije, u: BS, 73 (2003) 4, str. 619-630.

${ }^{135}$ Usp. Isto, str. 25.

${ }^{136}$ Usp. KUSIĆ A., Dva aspekta suvremenog egzistencijalizma, u: CUS, 11 (1976) 2, str. 123-124.
} 
činjenici da vjeruje te prirodnom poretku usprkos odgovori poticaju svoje slobode i odluke da bude ono što jest, ili pak otkrije znak da ono „uočeno“, to nešto, izmiče općim, univerzalnim znanjima te postaje nešto osobito, izvanredno, baš ovdje osmišljeno i s razlogom. ${ }^{137}$ On je smatrao da je kršćanstvo u svojoj najdubljoj osnovi osobna, to jest intimna vjera pri čemu tek ona omogućava pojedincu da ostvari svoju slobodu, odnosno da se ostvari kao slobodno i svjesno biće te se, što je prijeko važno, oslobodi straha. Svoju konkretnost čovjek dakle ostvaruje tek kao egzistenciju pred Bogom. ${ }^{138}$

Iz Kierkergaardovih je razmatranja o strahu razvidno kako on strah, te posebno s njim povezanu tjeskobu, vezuje ponajprije s (ljudskim) duhom koji može podnositi te fenomene. U tome će smislu reći: „Život je proigrao samo onaj koji nije postao svjestan sebe kao duha, niti toga da stoji pred Bogom. “139 Duhovnost se, prema danskom filozofu, očituje u potrazi za Bogom pri čemu taj ,put duhovnosti“ nije univerzalan, pogotovo ne unaprijed određen i usustavljen od institucije Crkve, već je on za svakog pojedinca koji je u procesu traženja originalan i jedinstven. Kod Kierkegaarda se strah pred nečim što još nije tu - tjeskoba ili bojazan - pojavljuje osim na duhovnoj razini također i kao „nemir u slobodi“. Dimenziju slobode Kierkergaard ovdje unosi zbog čovjekove odluke suočavanja s onim ništa. Upravo je ono, kao ponor pred kojim čovjek stoji, predmet tjeskobe i stalno iskrsava. Strah je uz tjeskobu zapravo stanje mislećeg i, dakako, slobodnog duha u kojem čovjek razmišlja o budućnosti. Samo onaj čovjek koji ništa ne misli može biti slobodan od tjeskobe i straha. ${ }^{140}$ Međutim, prema danskom filozofu, mišljenje nije put rješavanja tjeskobe. Štoviše, ono - ako ostane bez vjere - nužno završava u ponoru besmisla jer potrebuje nadopunu. Upravo je to i jedan od razloga zbog kojeg se danski filozof odlučuje za vjeru i u pogledu straha. ${ }^{141}$

Kratkim pregledom Kierkergaardovih djela uočavamo da on sve stavlja u pitanje, odbacuje ustaljene sustave vjerovanja te nastoji čovjekov unutarnji život staviti u središte svog promišljanja. Naime, Kierkegaard je bio mišljenja kako prvi i najvažniji zadatak svakog pojedinca jest staviti sebe u središte s ciljem traženja samog sebe. ${ }^{142}$ Unutarnji je život za Kierkegaarda jedina ozbiljna stvar na koju treba obratiti pozornost, pri čemu on nikako ne odustaje od teze da je Bog onaj koji otkriva čovjeku njegov pravi poziv i put kojim treba

\footnotetext{
${ }^{137}$ Usp. Isto, str. 123-124.

138 Usp. Isto, str. 123-124. Svakako ćemo se Kierkergaardovim razmatranjima posvetiti kasnije kada budemo posebno govorili o pojmovima straha i tjeskobe, kod njega također nadaleko poznatima.

${ }^{139}$ Usp. KIERKEGAARD S., Strah i drhtanje, str. 30.

${ }^{140}$ Usp. KALAS̆EVIĆ G., Kafkino hrvanje sa strahom, str. 11.

${ }^{141}$ Usp. BOŠNJAK B., Povijest filozofije 3, Matica hrvatska, Zagreb, 1993., str. 177.

142 Usp. BEER-SHEVA, Kierkegaard: Kako domišljat teolog nalazi nesreću, prev. Bertman M. A., u: FI, 9 (1989) 1, str. 130.
} 
kročiti. Ovaj je religiozni filozof poznat po tome što u svojim tekstovima, odnosno promišljanjima, redovito napada službenu dansku Crkvu kojoj je zamjerao zaborav izvorne istine kršćanstva. Prema njemu, (ono kako) biti kršćaninom znači zapravo jednostavno svjedočiti kršćanstvo i takvim postati. Kršćanstvu je zamjerao sklonost izvanjskom i prilagođavanje svijetu te je isticao svetost $\mathrm{i}$ na nju je pozivao. Iznimno ga je smetala svjetovnost koju posebno pripisuje tada vladajućem luteranstvu. U tom okretanju čovjeka $\mathrm{k}$ onom unutarnjem u vidu duhovnosti, kako je poznato, on dolazi - uz strah, tjeskobu općenito do patnje koja u ovom slučaju nije izazvana ničim radikalno izvanjskim, nego se porađa iz te same čovjekove unutarnjosti. Upravo ovdje možemo uočiti velebne Kierkergaardove uvide do kojih će doći kasnija psihologija o strahu te posebno tjeskobi. Tjeskobu ${ }^{143}$, naime, ona tumači kao izvjesno stanje nelagode, pritajenog straha kojem ne znamo uzrok. Tjeskoba jest ujedno i patnja koja svoje upotpunjenje nalazi u vjeri. Ovaj je danski filozof stoga došao do uvida kako se upravo u patnji produbljuje vjera pojedinca. Radi se o svojevrsnoj patnji duše jer čovjek prilikom promatranja svoje unutarnjosti prepoznaje svoju osrednjost, konačnost, nedostatnost. Na Kierkergaardovim će temeljima graditi svakako i Welte koji uvijek iznova ukazuje na klasičan, no uvijek nov i jedinstven put za svaku osobu kojim ona može kročiti u izbavljenju od patnje - taj je put bitno obilježen Bogom, odnosno usmjeren je na samu osobu Boga koji pak prije svakog rješenja ili oslobođenja od patnje čovjeka dovodi do unutarnjeg obraćenja. To je obraćenje koliko vjerničkog, toliko i egzistencijalnog karaktera pri čemu čovjek, s obzirom na potonje, dolazi do krucijalnog uvida da Bog kao transcendentno i od njega odvojeno biće daje (izvana) potpuni smisao njegovoj egzistenciji. $^{144}$

U razradbi se pojma „Angst“ (strah) i M. Heidegger oslanja upravo na Kierkegaarda. On razlikuje „Furcht“ (bojazan) i „Angst“ (strah). Za Heideggera je strah jedan modus čuvstvovanja (Empfindlichkeit). ${ }^{145}$ Čuvstvenost je način na koji se nalazimo u svijetu. Upravo

\footnotetext{
143 Tjeskoba/anksioznost. Kompleksno neugodno čuvstvo tjeskobe, bojazni, napetosti i nesigurnosti, praćeno aktivacijom autonomnog živčanog sustava. Termin tjeskobe/anksioznosti uveden je u psihologiju 1894. godine Freudovim opisom anksiozne neuroze, koristi se u suvremenoj psihologiji kako za opis čuvstvene reakcije izazvane nepoznatim ili neprepoznatljivim uzrocima, tako i za čuvstvena stanja pobuđena realnom ili predvidivom opasnošću. Kao i mnoge druge čuvstvene reakcije, anksioznost ima i motivacijsko djelovanje. Umjerena razina anksioznosti često pozitivno djeluje na učinak u različitim aktivnostima, dok odsustvo svake anksioznosti, kao i vrlo intenzivna anksioznost, smanjuje učinak (npr. u testovima inteligencije i znanja). Intenzivna anksioznost javlja se uz mnoge psihičke, ali i fiziološke poremećaje kao što su: nedostatak vitamina B, hipoglikemija, endokrini i kardiovaskularni poremećaji te početne faze niza tjelesnih bolesti; u: PETZ B., Psihologijski rječnik, Prosvjeta, Zagreb, 1992., str. 19. Nas svakako ovdje zanima duhovni vid tjeskobe i njime ćemo se na predstojećim stranicama ovog rada i baviti.

${ }^{144}$ Usp. WELTE B., Filozofija religije, str. 91-93.

${ }^{145}$ Usp. HEIDEGGER M., Bitak i vrijeme, str. 159.
} 
i kroz prizmu straha mi gledamo stvarnost. On strah raščlanjuje na tri dijela: 1. Pred-čim straha, ono strašno je „ono“ što čini da se bojimo. Strah dolazi iz cjelokupnog bića - ljudi, instrumenti i postojeće. Strah najviše izaziva ono što će doći, što još nije došlo. To iščekivanje jest zapravo ono strašno. To je strah do krajnjih granica ${ }^{146} ; 2$. Samo je strahovanje otkrivanje onog što prijeti u njegovoj strahoti. ${ }^{147}$; 3 . Ono za-što strah jest samostrahujuće biće, tubitak. Samo onaj kojem je stalo do njega samog može se bojati. To je pozitivni segment straha. ${ }^{148} \mathrm{Iz}$ ovog proizlazi kako je strah uvijek vezan uz buduće - uz ono što će doći. Heidegger smatra da je dimenzija vremena straha vezana uz prošlost. Tubitak je egzistencijalna mogućnost za moći-biti koja se zrcali u trajnom još-ne. On je bačen u bitak, ne zna odakle dolazi niti kamo ide. Ništavost je ta koja izaziva strah. Strah je u sferi onostranog. Budući da sam stvoren od „Ništa“, ono uvijek prijeti da me pozove k sebi. ${ }^{149}$

\subsection{Smislenost čovjekova postojanja i strah - Welteova razradba straha}

Kada se radi o filozofskim preokupacijama fenomenom straha, Welteu se kao izazovni pokazuju spomenuti teoretičari poput F. Kafke ${ }^{150}$, S. Kierkegaarda ${ }^{151}$ i M. Heideggera ${ }^{152}$ te također, kako na jednom mjestu kaže, njihov stariji prethodnik Blaise Pascal. Fenomen straha (kao i uz njega potaknute nade) oduvijek proizlazi iz čovjekove zaokupljenosti vlastitim postojanjem. Welte je mišljenja kako je strah, čak kao i svojevrsni uvjet, specifičnost modernog vremena. Već spomenuti Kafka piše na jednom mjestu: „Moja priroda je i strah, ja se sastojim od nje“. ${ }^{153}$ Strah kod Kafke biva označen kao zastrašujući gost. Porastom utjecaja koji su dolazili od racionalizma, prosvjetiteljstva, napretka znanosti i tehnologije i pojam straha se počeo pojavljivati kao nešto neodvojivo od suvremene situacije u kojoj se osoba nalazi i živi.

Upravo stoga valja promatrati i nadu u kontekstu tjeskobe, to jest brige (Sorge) i bojazni (Furcht) -pojmova spomenutih kod M. Heideggera. Nada izvire u svojoj najdubljoj osnovi iz stanja straha te se odnosi na pojedinca kojem je (čitav) život obilježen tjeskobom, a

\footnotetext{
${ }^{146}$ Usp. WELTE B., Filozofija religije, str. 160-161.

${ }^{147}$ Usp. Isto, str. 160-161.

148 Usp. Isto, str. 161.

${ }^{149}$ Usp. KALAŠEVIĆ G., Kafkino hrvanje sa strahom, str. 12.

${ }^{150} \mathrm{Na}$ Kafku se Welte posebno referira u djelu Gesammelte Schriften I/1 Person, str. 242. i 246.

${ }^{151}$ O Kierkegaardu Welte govori na više mjesta u svojem djelu Gesammelte Schriften I/I Person, i to poglavito na str. 81., 91-93., 106., 241-244., 247., 278. i 280.

152 O Heideggeru Welte govori u svojem djelu Gesammelte Schriften I/1 Person, posebice na str. 24-26., 91-94., 176-177., 242., 244. i 249.

${ }^{153}$ Usp. WELTE B., Gesammelte Schriften I/1 Person, str. 48.
} 
koja se upravo može odrediti kao stanje između osjećaja straha i nade. ${ }^{154}$ Prema Jean-Paul Sartreu, kojeg se Welte dotiče u svojem promišljanju o fenomenu straha, sam strah te osamljenost i nesigurnost prepoznaje upravo u nemogućnosti čovjeka da predvidi posljedice vlastitih postupaka i djelovanja. ${ }^{155}$ Upravo se iz te nemogućnosti, reći će Sartre, u čovjeku javlja anksioznost koja je prvi uvjet kasnijeg rađanja straha. Da bismo bolje razumjeli zašto se strah javlja, svakako je potrebno promotriti situaciju u kojoj se čovjek nalazi, njegovu trenutnu smještenost i same okolnosti. Negativno poimanje straha često je završavalo u negativnim iskustvima, kao što je to slučaj upravo kod Sartrea čije je iskustvo skončavalo u radikalnom negiranju transcendencije, odnosno u ateističkom nihilizmu. Nasuprot negativnom poimanju straha nalazi se i ono poimanje kakvo dolazi od kršćanskog egzistencijalizma koji iznosi na vidjelo iskustvo tubitka kao osobne komunikacije i participacije u Transcendentnom - i taj se tubitak utemeljuje u apsolutnom osobnom Božjem bitku pri čemu je polazište ,jaiskustvo““ ${ }^{156}$ Istaknuti filozof J. M. Bochenski reći će u tom kontekstu sljedeće: „To je osvijetljeni prostor u kojemu sam sebi postajem prisutan, u koji unosim svijet te tako on postaje moj svijet i konačno prostor u kojemu sam sobom raspolažem. Radi se o veličini i malenosti (bijedi) mojega ja“. ${ }^{157}$

Welte je mišljenja da čovjek traži sreću, teži k tome da bude sretan, teži k spasenju, želi biti cjelovit i ispunjen; sve ono što čovjek nastoji i čini te, kako živi, pokušava jednostavno osmisliti. Da bude ispunjeno barem i djelomičnim smislom. ${ }^{158}$ Upravo iz toga vidimo kako je smisleno postojanje, ma na kakav ga način osmišljavao, neodvojivo od čovjeka; postojanje se u takvom smislu ne može zanemariti. Welte tvrdi kako postojanje nije nikad ravnodušno prema nama. Od postojanja uvijek nešto očekujemo i bavimo se nečim, poput smisla. ${ }^{159} \mathrm{U}$ svemu i svakom od nas, bilo da nešto radimo ili o nečem pričamo, postoji smisao i smislenost. Djelujemo tako da svoje svakodnevne, čak i najmanje, dužnosti i poslovi imaju barem djelomičan smisao, iako nam se čine automatizirane. Na prvi se pogled čini kako je određeno osjetilno stanje univerzalna pretpostavka našeg života i rada općenito. Međutim, racionalnim radnjama i ponašanjem upravo pretpostavljamo da pitanje smisla ima pozitivan predznak i pozitivno obilježje te čovjeku daje svojevrstan polet. No vrijedi i obrnuto: u onoj mjeri u kojoj bi pretpostavka smisla postala sumnjiva, ili čak i izostala, snaga i hrabrost života

\footnotetext{
${ }^{154}$ Usp. HEIDEGGER M., Bitak $i$ vrijeme, str. 159-162.

155 Usp. SARTRE J.P., Ist der Existentialismus ein Humanismus, u: SATRE J. P., Drei Essays. Ullstein Materialen, Frankfurt - Berlin - Wien, 1983., str. 180.

${ }^{156}$ Usp. BOCHENSKI J. M., Uvod u filozofsko mišljenje, Split, 1997., str. 79-89.

${ }^{157}$ BOCHENSKI J. M., Isto, str. 79-89.

${ }^{158}$ Usp. WELTE B., Gesammelte Schriften I/1 Person, str. 242-245.

${ }^{159}$ Usp. Isto, str. 245.
} 
potonuli bi i na kraju nestali. Welte kaže kako oni koji ne bi vjerovali u smisao ili koji ne mogu vjerovati da postoji smisao, ne mogu više skladno ni normalno živjeti. ${ }^{160}$

Welte je mišljenja kako mogućnosti koje nadolaze osobi kao »buduće mogućnosti« njezina vlastita svijeta određuju čovjekovo trenutno postojanje. ${ }^{161}$ Isto tako mogućnosti mog svijeta utječu na moju slobodu te se treba zapitati što to mogu učiniti za svoju slobodu s mogućnostima koje posjedujem? Mogućnosti mog svijeta utječu na mogućnosti moje slobode. Iz te se interakcije oblikuje moja budućnost. Dvije mogućnosti ove interakcije, mogućnosti svijeta i slobode, nije moguće sa sigurnošću odrediti, pojmovno niti sadržajno, te ostaju svagda neodređene. ${ }^{162}$ Od svijeta se može očekivati puno, a nešto možda i predvidjeti, međutim, uvijek ostaje otvoreno pitanje mogu li zaista sa sigurnošću nešto znati. Welte ovdje daje primjer dnevnog tiska koji čitamo iz dana u dan, kao u nekoj obrednosti. Dnevni je tisak dobar primjer gdje svakodnevno saznajemo nešto novo, što nismo znali jučer i što zasigurno nismo mogli pretpostaviti prije toga. Upravo iz toga razloga ne možemo biti sigurni u svoju budućnost, već joj idemo sa stavom otvorenosti, koliko god ju pokušali predvidjeti, odnosno kanalizirati u smjeru u kojem to sami želimo.

Upravo se u nedostatku smislenosti javlja strah kao fenomen koji treba prepoznati i njime se baviti. Ono što je bitno na tom putu jest prepoznati kako život i živo postojanje znače za osobu biti zainteresiran za svoje vlastito postojanje i pretpostaviti da ono sadrži smisao te zatim djelovati u smjeru ostvarenja zadane nam smislenosti. S obzirom na to, mi se - reći će Welte - zainteresirani i smisleni pronalazimo i ostvarujemo u svijetu. Što se pak tiče budućnosti koja dolazi ili koju anticipiramo, mi uvijek nešto činimo ili radimo za neku buduću korist ili nadolazeću (bolju) budućnost. Jer budućnost određuje i usmjerenje čovjeka. No kada se radi o budućnosti za koju znamo da postoji i da dolazi, ipak je to uvijek neodlučena budućnost o kojoj ništa osobito ne možemo znati. No smislenost nas tjera naprijed ususret budućnosti i budućem ostvarenju. Budućnost i smislenost (osmišljenje) dolaze tako u tijesan odnos. Zahtjev za smislenošću preduvjet je smislene budućnosti. Jer je vlastita svakom čovjeku, naša nas budućnost zanima te očekujemo od nje smislen oblik našeg postojanja. Interes za budućnost i njezino značenje - dvije karakteristike neodvojive jedna od druge i od čovjeka - tvore čovjekovu osnovnu situacijsku smještenost. Zapitamo li se što to točno tvori oblik budućnosti, odgovor ide u sljedećem smjeru: budućnost nastaje iz interakcije mogućnosti mog svijeta, to jest iz onog s čim se kao čovjek susrećem u okviru mogućnosti

\footnotetext{
${ }^{160}$ Usp. Isto, str. 246.

${ }^{161}$ Usp. Isto, str. 245-251.

162 Usp. Isto, str. 242-245.
} 
prirode, npr. zdravlje, bolesti, društveno okruženje i kontakti, uspjeh - ukratko, svi oni utjecaji i ideje kojima će čovjek biti izložen na tom putu ostvarenja smislenosti vlastita života.

Nadalje budućnost nužno promatramo u povezanosti sa slobodom. Tako se, s obzirom na taj odnos, pitamo i možemo li biti sigurni u svoju slobodu te možemo li vjerovati sebi i biti sigurni u sebe, a s obzirom na budućnost? Odgovor, dakako, ide u smislu da se budućnost oblikuje interakcijom dvaju otvorenih i nikad sasvim određenih horizonata mogućnosti i tako je rezultat ove međusobne interakcije dvaju neodređenih horizonata mogućnosti još neodređeniji. Ova situacija, prema Welteu, zapravo može biti prilično zastrašujuća za čovjeka. To je situacija koja izaziva strah pred onim što još nije. ${ }^{163}$ Budućnost je doista neodređena u svom sadržaju, ali i u svojoj biti koju možemo odrediti pojmom „nadolazeća“, ona je određena. Bit joj je dakle u tome da (nužno) (na)dolazi. Ili jednostavnije: sve što možemo znati za budućnost jest to da joj idemo ususret, odnosno da (na)dolazi. Ono neizbježno uvijek dolazi do nas i mi tome bivamo predani, štoviše, izručeni - sviđalo se to nama ili ne. Ne možemo znati što dolazi niti mu možemo izmaći, barem ne sasvim. U svemu tome nadolazećem i s tim vezano u nedostatku smislenosti postojanja uvijek se javlja strah. Za bolje razumijevanje toga čemu ne možemo izmaći, a svjesni smo da dolazi Welte koristi primjer Pascalove oklade. ${ }^{164}$ Naime, Pascal je tu situaciju nazvao situacijom neizbježnosti. Poznat je njegov fragment u kojem se spominje oklada. Ako se već ukrcamo na brod, nema smisla razmišljati želimo li ići na put ili ne. Upravo u toj neizbježnosti neodredive budućnosti dolazi do izražaja oštrina naše osnovne situacije koja nas plaši. Za Pascala nije toliko bitan sam pojam straha, već sve ono u što je strah kao pojam uključen te njegova glasovita oklada koju Welte u svojem promišljanju o Osobi i pojmu nade na tom putu razmatra, svakako i vrednuje. $^{165}$ Zahtjevnim se nameće dotaknuti se kratko tog zanimljivog Pascalovog obrazloženja.

\subsubsection{Pascalova oklada i Welteovo poimanje neizbježnosti u pogledu onoga s čim se susrećemo}

Temelj i uvjet ove Pascalove teorije jest to da svaki čovjek ima mogućnost susresti Boga, no ulazeći dublje u te misli, Pascal je zaključio da je Bog - ako postoji - nužno nedokučiv. Mi kao konačna i ograničena bića nismo sposobni znati postoji li Bog. Ako svoju

\footnotetext{
${ }^{163}$ Usp. Isto, str. 242-251.

${ }^{164}$ Usp. Isto, str. 157.

${ }^{165}$ Usp. Isto, str. 48.
} 
spoznaju i percepciju temeljimo na iskustvu, Bog nam ostaje nedokučiv jer on ne nalikuje ni na jednu nama poznatu stvar. Ali to nije ono primarno u Pascalovoj okladi; on želi potaknuti čovjeka da donese nužno egzistencijalnu odluku. Ova, kao i svaka druga oklada, ima prednosti ako je eventualni dobitak veći od početnog uloga. Pascal tu računicu primjenjuje na ljudski život, uzimajući ovozemaljski život kao ulog, a vječni i blaženi život kao eventualni dobitak. Ovdje je vidljiv ogroman utjecaj Pascalove teorije vjerojatnosti. Pascalova oklada polazi od prihvaćanja dvaju krajnosti: Bog postoji ili ne postoji. Razum je u ovoj situaciji vrlo ograničen i priklanja se jednako i jednoj i drugoj strani. Logično je, smatra Pascal, kladiti se da Bog postoji jer ako postoji i dobijemo tu okladu, dobit ćemo sve. Ako se pak kladimo da Bog postoji i izgubimo, nećemo zapravo izgubiti ništa - iz tog je razloga prirodno kladiti se da On postoji. Nastojeći dotaknuti sve aspekte, odnosno argumente pro i contra Pascalove oklade, Welte dosljedno,na tu okladu iznosi i tzv. odgovor ateista, sadržan također u sličnoj okladi, međutim, s bitnom razlikom u prihvaćanje postojanja Boga: „Najbolje je živjeti puni život i pokušati učiniti ovaj svijet u kojem postojimo što je moguće boljim, neovisno o tome vjerujemo li u Boga ili ne vjerujemo. Ako Bog ne postoji, ne gubimo ništa, a ostati ćemo upamćeni po dobroti od onih koji ostaju iza nas. Ako postoji Bog koji je dobar, tada ćemo biti suđeni po svojim zaslugama, a ne po činjenici vjerujemo li u Njega ili ne. “166 Pojedini autori s pravom ističu kako Pascalova oklada nije zamišljena kao jedan od argumenata za dokazivanje Božje opstojnosti, nego više argument da je razumno vjerovati u Božju egzistenciju i da je nerazumno biti nereligiozan. ${ }^{167}$ I, zaista, ako se pogleda pozornije, Pascal ne pokušava dokazati nikakvu razumsku istinu, on želi samo potvrditi da je vjera razuman, smislen te potpuno egzistencijalan izbor za čovjeka. ${ }^{168}$ Upravo se u Pascalovoj filozofiji događa obrat prema konkretnom čovjeku koji u svojoj unutarnjosti i srcu posjeduje instinkt, intuiciju, osjećaje i tankoćutnost te se ne može izjednačavati s onim krutim i strogim Descartesovim matematičko-racionalnim mišljenjem. ${ }^{169}$ Čovjek kao osoba - živo biće uvijek je puno više od tek matematičkih formula i logičkih zaključaka. Motiv na temelju kojeg Pascal uopće donosi svoju okladu jest strah ili tjeskoba pred neizvjesnošću. On ju zanimljivo rješava „prepuštanjem“ bez velikog premišljanja. Prepuštanjem (on ovdje, kako smo vidjeli, spominje sliku ukrcaja na brod) koje znači prihvaćanje postojanja Boga upravo i iz tog razloga, jer ono daje rješenje kako u egzistencijalnom pogledu smisla općenito, tako i pojedinačnih

\footnotetext{
${ }^{166}$ Usp. Isto, str. 242-245.

167 Usp. TUDOR M., Bog filozofa - Bog Abrahama, Izaka i Jakova u mislima Blaisea Pascala, u: Nova prisutnost, 5 (2007) 2, str. 208.

${ }^{168}$ Usp. Isto, str. 208.

${ }^{169}$ KUSIĆ A., Dva aspekta suvremenog egzistencijalizma, u: Crkva u svijetu = CUS, 11 (1976) 2, str. 123-124.
} 
individualnih strahova specifično. Konačno, čovjek je, prema Pascalu, dijalektičko biće koje svoj potpuni smiraj može naći samo u živom Bogu Objave. ${ }^{170}$

Iz svega rečenog da se zaključiti kako je Welte poimanje straha usko vezao uz spomenute autore i njihovom mišlju produbljivao vlastitu misao. Strah je za Weltea neizbježna stvarnost koja na putu života pronalazi svakog čovjeka, pogađa njegovu osobu i osobnost, posebice ako izostane ili ako čovjek zaboravi na smislenost vlastita postojanja. No, prema freiburškom filozofu, uvijek postoji mogućnost povratka k smislenosti vlastita života $\mathrm{i}$ put k tome jest pouzdanje u Boga koji je veći od svake čovjekove ograničenosti i konačnosti.

\subsection{Tjeskoba kao sastavni dio straha: Welteova 'hrabrost za strah'}

Već spomenuti pojam tjeskobe u Welteovu promišljanju o osobi zaslužuje dublju pozornost. Tjeskoba (Furcht) je u Welteovu promišljanju o osobi usko vezana uz fenomen straha (Angst) i iz njega proizlazi. Osnovna ljudska situacija iz koje proizlazi tjeskoba, prema Welteu, otkriva sva ona pitanja s kojima se susrećemo: je li naše postojanje ovisno o ovom ili onom te što je u osnovi u mogućnostima s kojima se susrećemo, odnosno daju li se one svesti samo na dvije dimenzije, naime, one koje nas privlače i one koje nam prijete? ${ }^{171}$ Pitanja koja zasigurno obilježavaju osobni život pojedinca i njegovu situaciju jesu sljedeća: kamo, odnosno prema komu/čemu idemo, za što je dobro da smo tamo gdje idemo? Ljudi se često mogu osjetiti napadnuti takvim pitanjima, pri čemu taj »napad« duboko pogađa svakog pojedinca i njegove misli. Razlog tomu leži u činjenici što se ljude time u njihovoj svakodnevici trga iz ustaljenih obrazaca, redovitosti koja nije osobito inovativna, odnosno kreativna, međutim, kao takva ne iziskuje pretjerani trud. Welte se na ovom mjestu opet vraća Kafki i smatra kako je to pitanje smisla ili sreće u cjelini neizmjerno, takoreći beskonačno pitanje. Međutim, tamo gdje je ono čak skriveno ili „oku“ duše nevidljivo, ipak tinja u pozadini misli svake pojedine osobe te uznemiruje njegovu svijest. ${ }^{172}$ To je, možemo reći, specifični strah koji proizlazi iz čovjekove situacije i pred onim još uvijek neodređenim koje je (već) filozofija označavala pojmom tjeskobe.

Radikalna mogućnost našeg postojanja sastoji se upravo od činjenice da ona sigurno završava smrću. Stoga naša najsigurnija budućnost, koja neminovno uključuje sve nas, što

\footnotetext{
${ }^{170}$ Isto, str. 123-124.

${ }^{171}$ Usp. WELTE B., Dasein als Hoffnung und Angst, str. 241-251.

${ }^{172}$ Usp. Isto, str. 241-251.
} 
god da odaberemo, jest sljedeća: da ćemo jednog dana umrijeti i da više nećemo biti. Koliko god da je smrt sigurna, toliko je i neizvjesno ono što se nalazi u njezinoj tišini i upravo iz toga proizlazi nesigurnost te da ničeg nema jer u smrti prevladavaju upravo tišina i tama. Stoga je razumljivije postojanje tjeskobe zbog neizvjesnosti o budućem životu negoli njezina odsutnost. Tjeskoba koja također sadrži bitne elemente straha ima i prirodnog neprijatelja, ono što mu dolazi ususret iskorjenjujući ga i zove se izvorno povjerenje koje je duboko ukorijenjeno u ljudskoj prirodi. Prije negoli je stupio na područje religije, Welte iščitava u ljudskoj osobnosti elemente koji su fascinirajući i svakako ne na prvi pogled vidljivi. Bez tog (izvornog) povjerenja, više nesvjesnog nego svjesnog, ne bismo mogli ni živjeti. Nesvjesnog - jer ga pretpostavljamo te se u svakodnevici njime obilato služimo: čitav naš život i djelatnost strukturirana je od tog načelnog povjerenja. Djelujemo s pretpostavkom (vjerom) da će dogovor ispoštovati, razgovaramo s pretpostavkom (povjerenjem) da nam druga strana načelno govori istinu, donosimo odluke s pretpostavkom (povjerenjem) da će okolnosti biti takve da ćemo ih moći (odluke) izvršiti itd. Čak i djeca, kaže Welte, utjelovljuju iznimno mnogo od tog izvornog povjerenja. Ono čini da strah, odnosno tjeskoba, nestane ili da se barem uvelike smanji.

Ovdje se radi o svojevrsnoj bezbrižnosti, usporedivoj sa svakodnevnim pojavama sna i igre. Prva od spomenutih stvarnosti, san, očituje bezbrižnost na osobit način. U snu smo lišeni svake brige i tjeskobe, ostavljamo svijet njegovu tijeku i prepuštamo se onom tajnom tijeku stvari: spavanje je stoga jedna od velikih manifestacija ovog izvornog povjerenja i jedan od najdragocjenijih darova koji su čovjeku dani. ${ }^{173}$ Druga pojava koja se tiče izvornog povjerenja, i s njim suočavanja s tjeskobom, jest igra. U igri djeca i odrasli razvijaju vlastiti svijet bez straha i napetosti. Dakle, prema Welteu se, kako u snu, tako i u igri strahovi od postojanja mogu zaboraviti i na trenutak barem potisnuti. ${ }^{174}$ No i s tim treba biti oprezan te na ovom mjestu filozof religije spominje još jednom Pascala koji je upozoravao na ono što može biti skriveno u prevelikom opuštanju i bezbrižnosti kako se ne bi dogodilo da bezbrižno otrčimo u ponor. Klasična formulacija potiskivanja straha općenito je ljudska, ali posebno povezana s modernim društvom čiji je svjedok i kritičar zasigurno bio i Pascal.

Kada se nadalje radi o specifičnom obliku straha - tjeskobi - treba se također zapitati postoji li ikakav način da se taj strah prevlada u smislu „distrakcije“ kako ju je to Pascal nazvao. Isto tako valja postaviti i drugo pitanje: zašto se to izvorno povjerenje, pripadno

\footnotetext{
${ }^{173}$ Usp. Isto, str. 241-251.

${ }^{174}$ Usp. Isto, str. 241-251
} 
svakom čovjeku, ipak čini tako krhkim i nestalnim te čovjek ne doživljava samo tjeskobu kao nešto odvojeno od sebe, već se sam poistovjećuje s njom, naime, postane tjeskoban. ${ }^{175}$ Welteov odgovor ide u smjeru kako prevladavanje tjeskobe mora biti prevladano na način ispravnog razumijevanja straha u njegovoj osnovi. Prevladavanjem onog što se naziva ljudska nesigurnost. Ovdje jedino pomaže hrabrost kao nova karakteristika, duboko ukorijenjena u čovjeka i već spomenuto izvorno povjerenje. Kada čovjek zadobije tu hrabrost, tada strah postaje, Welteovim riječima, jedan taman anđeo, ali ipak anđeo, kojeg je trenutno obuzeo pritisak da potiskuje i prikriva istinu čovječanstva te po toj hrabrosti čovjek biva sposoban osloboditi se. To je prvi korak k oslobađanju čovjeka. ${ }^{176}$ »Hrabrost za strah« - što pak očituje kreativni vid tjeskobe, stanje u kojem se iz nesigurnosti rađa povjerenje u samog sebe moguća je u konačnici jedino ako se čovjek prepusti daru vjere kao početnom daru života koja kao snaga Božja obuhvaća sav život i smrt. ${ }^{177}$ Ako se dakle tjeskobni čovjek usudi dosegnuti granice ljudskog te nadljudskog i božanskog, ako se usudi prepustiti u vjeri i nadi, oporavit će se u Onom koji ima sve u svojim rukama. Takva je vjera, prema Welteu, sposobna živjeti odobravanje Isusa koji je sam svjedok spasenja i Boga, koji je na kraju izliječio svako zlo. Ako čovjek ima pouzdanje u Onog koji ga je stvorio, tada se u njemu obnavlja izvorno povjerenje u život. Povjerenje je u Weltea središte u kojem se razrješuju spone tjeskobe. Ono pak mora biti ukorijenjeno, pokazuje nam svakodnevno iskustvo, u osobi. Za vjernike je to Bog. Uvjet pak takvog povjerenja i s njim nadvladavanja tjeskobe pronalazi se u vjeri. Vjera u kršćanskom smislu može potaknuti čovjeka na razmišljanje ne tek o tjeskobi kao općenitom stanju, već o onom što nju konkretno uzrokuje: vlastita smrt, prijeteći, zastrašujući i tajanstveni kraj.

Prilikom takvog razmišljanja čovjek koji je duboko u vjeri razmišljat će o smrti tako da zna da postoji netko moćniji od smrti, Bogu koji poziva mrtve na novi pashalni život, probudivši svog ljubljenog Sina, na eshatološku puninu života. Nietzsche je pisao kako je »Bog mrtav«, u vidu prevrednovanja svih moralnih i religioznih vrijednosti, čime je, reći će Welte, izrazio bezbožje modernog čovjeka. Na njegovo mjesto tada dolaze praznina, apsurd i ništavilo. Welte pobliže propituje to ništavilo koje okružuje naše postojanje i pokazuje kako sámo iskustvo ništavila ne mora nužno značiti radikalnu besmisao, već da se i u ništavilu može prepoznati tajanstveno svjetlo. ${ }^{178}$ Naš filozof religije i tako otvara prostor za religiozno

\footnotetext{
${ }^{175}$ Usp. Isto, str. 241-251

176 Usp. Isto, str. 249.

${ }^{177}$ Usp. Isto, str. 249-250.

${ }^{178}$ Usp. WELTE B., Das Licht des Nichts. Von der Möglichkeit neuer religiöser Erfahrung, ur. Zaborowski H., Topos, Kevelaer, 2015., str. 39-40.
} 
iskustvo koje svakog pojedinca nosi i podnosi (prividni) besmisao. Zaključno, povjerenje i nada veliki su protivnici straha i tjeskobe koji čovjeka zaokupljaju u životu. Oni su snažniji od izvornog, egzistencijalnog straha te omogućuju čovjeku da bude čak i grješnik, da bude svjestan svoje prolaznosti i smrtnosti. ${ }^{179}$ Omogućuju mu da bude ono što on uistinu jest: istodobno ranjiv i smrtan, prolazan i nedostatan, ali s nadom u ono što dolazi. Prema Welteu, to je jedini ispravan put za osobu koja tako biva sposobna pobijediti svaku sumnju, strah i tjeskobu.

Zaključimo da u nadilaženju straha Welte ponajprije predlaže njegovu jasnu spoznaju, ma koliko strašna bila, kako na to s pravom ukazuju mnogi psiholozi i psihoanalitičari. ${ }^{180}$ Međutim, ona za Weltea nije konačna i apsolutna u razrješenju straha. Tako za razliku od Fichteova stava valja ponovno istaknuti kako u njegovu razrješenju stoji ono izvorno povjerenje o kojem je govorio Kierkergaard te ga Welte preuzeo. Dok s jedne strane strah paralizira, s druge povjerenje oživljuje i obnavlja čovjeka. Uz povjerenje nužno ide i pouzdanje koje pak u svojem temeljnom značenju uključuje pojam vjere - pouzdati se $\mathrm{u}$ nekog (nečeg) znači vjerovati mu. ${ }^{181}$ Pouzdanje stoga daje snagu, krijepi i jača. Ono je oblik prepuštanja sebe Bogu. U vjeri se vjernik ozbiljno i zbiljski ispušta iz ruku vlastite skrbi o samom sebi, iz vlastitog raspolaganja samim sobom, vlastitog ustrajanja na samom sebi prema bitno drugom, različitom - Bogu. ${ }^{182}$ Prepustiti samog sebe zbiljski i posve znači prepustiti sebe i cijeli svoj svijet Tajni koja nadilazi sve ovozemaljsko. Upravo se predanjem, odnosno pouzdanjem vjera i nada istinski upotpunjuju čineći jedan prirodni put $\mathrm{k}$ Bogu. Konačno, prepuštajući se i potvrđujući Boga, vjera dobiva značenje jednog bezuvjetnog predanja. Welte tako, vidjeli smo, dolazi do uvida da vjerovati u Boga znači također vjerovati i u samog sebe, iz Božje ruke prihvatiti sama sebe, onakvog kakav tko jest. ${ }^{183}$ Tako čovjek i samog sebe prekoračuje prema uvijek nedostižnom, ali stremećem idealu te mu je pogled usmjeren kroz nadu u budućnost života koji on sam (čovjek) živi na njemu osobit i originalan način.

\footnotetext{
${ }^{179}$ Usp. WELTE B., Dasein als Hoffnung und Angst, str. 250-251.

${ }^{180}$ Usp. NIKIĆ M., Psihologija straha, u: Strah - naš životni pratilac, ur. Valentin Pozaić, FTI - Centar za bioetiku, Zagreb, 1995., str. 33-35. Welteovi su uvidi ovdje, što je pohvalno, iznimno bliski psihoanalitičkim postavkama suočavanja sa strahom i traumom.

${ }^{181} \mathrm{Njem}$. sich verlassen $=$ pouzdati se.

182 Usp. WELTE B., Filozofija religije, str. 163.

${ }^{183}$ Usp. Isto, str. 164.
} 


\section{Ljudsko postojanje i igra kroz prizmu sreće}

\subsection{Uvod i postavljanje problema}

Igra je u okviru ljudskog postojanja oduvijek imala važnu ulogu kako u antropološkom, to jest kulturalno-običajnom pogledu, tako i u mnogim znanostima gdje su stvorene različite teorije igre koje tumače ponašanje ljudi ili životinja, njihovo društveno i kulturno okruženje i sam jezik. ${ }^{184}$ Toma Akvinski, kojeg Welte rado spominje, igru tumači razlikujući pri tome neumjerenu razuzdanost od igre veselog opuštanja koja je pozitivnijeg predznaka. ${ }^{185} \mathrm{Za}$ Tomu Akvinskog igra je s jedne strane ona koja raduje te s druge njezino djelovanje ima svrhu u samoj sebi bez nekog drugog cilja. ${ }^{186}$ Može se reći kako je igra tu radi nje same. Toma poistovjećuje igru s mudrošću i vrlinama koje su zabilježene još u Aristotela. Za umijeće igranja potrebna je kreativnost, opuštenost, bezbrižnost. Aristotel u Nikomahovoj etici govori o kreposti, »eutrapelia«, koja je označavala dosjetljivost i dobronamjernu šalu. ${ }^{187}$

Welteovo predavanje iz 1982. godine vezano uz pojam osobe i osobnosti, naslova Postojanje u simbolu igre, govori o tome kako je jedna od posebnosti našeg ljudskog života upravo u tome što se ponekad probijamo kroz njegovu svakodnevnu ozbiljnost onim što nazivamo igrom. ${ }^{188}$ Posebno je to uočljivo kroz dječju igru gdje je upravo djeci najsvojstvenije da se igraju jer im se život prije institucije škole (ali i za vrijeme škole) pretežno odvija u formi igre. Kako djeca odrastaju, i njihov život dobiva karakteristiku ozbiljnosti, tako i forma života postaje ozbiljnija te se i rad u životu osobe usložnjava, a (bezbrižna) igra nije više onog opsega kojeg je bila. Ona dakle ne iščezava u potpunosti, nego se pojavljuje na nov način u odrasloj dobi. Važan su primjer na ovom mjestu sportske igre, posebice se to vidi na primjeru nogometa u sveprisutnom javnom životu pojedinaca. Zato se Welte pita zašto uopće igrati i koji je smisao igre. Odgovor na ta pitanja ima nekoliko pravaca. Prvi je taj što u igri, iako možda kratko, zakoračimo uvijek u novi i drugačiji poredak stvarnosti u odnosu na uobičajeni radni život odrasle osobe koji po sebi predstavlja lakši i, takoreći, dječji. ${ }^{189}$ Welte izvrsno uviđa da u najdubljim osnovama čovjekove težnje posezanja za igrom leži žudnja za nepatvorenim i nevinim oblikom stvarnosti kakvu žive djeca. I više je nego očito da se osoba tako, dakle igrajući se, oslobađa tereta i ozbiljnosti svakodnevnog,

\footnotetext{
${ }^{184}$ Usp. KOPREK I., Sreća i igre na sreću. Etički okvir za razumijevanje jednog fenomena današnjice, u: Nova prisutnost, 11 (2013) 3, str. 373.

${ }^{185}$ Usp. AKVINSKI T., Summa theologica II-II, q. 168, a. 2-4.

${ }^{186}$ Usp. KOPREK I., Sreća i igre na sreću. Etički okvir za razumijevanje jednog fenomena današnjice, str. 374.

${ }^{187}$ Usp. Isto.

${ }^{188}$ Usp. WELTE B., Gesammelte Schriften Person I/1, str. 252.

${ }^{189}$ Usp. Isto, str. 252.
} 
realnog života. U ovom novom razigranom i olakšavajućem poretku naš se život tada opet pojavljuje, ali sada u prenesenom obliku. Pojavljuje se u simbolu. U tom je smislu to i drugi pravac odgovora na pitanje - čemu/zašto igra? Ona nam je potrebna kao simbol života kako bismo bolje mogli podnijeti ozbiljnost i težinu života. U simbolu igre, reći će Welte, život se pojavljuje u svim svojim dimenzijama (napora, poštivanja minimalnog reda, to jest pravila, komunikacije itd.), ali bez tereta i obveze koje dolaze drugim dužnostima. ${ }^{190}$ Igra, naime, djeluje lakše i prozračnije. Nadalje i treći pravac odgovora - igra se istodobno pojavljuje u korespondenciji s onim što se može označiti kao arhetipska osnova našeg života - prvo što činimo u životu jest da se igramo.

Slijedom rečenog igra nas podsjeća, odnosno usmjeruje na iskonsku slobodu, međutim, i na ono što možemo nazvati nadvladavanje vlastitih mogućnosti sadržano u maksimi uvijek više, bolje, jače. Arhetipska osnovna ovog više, bolje, jače svoj najdublji smisao postiže u iskustvu natjecanja i borbe - samih sa sobom, ali i još više s drugima. Tim više jer igra predstavlja neobvezatnost i nenavezanost na svakodnevno i redovito. I upravo se zato lakše i brže identificiramo s onim što se događa $u$ igri i kroz igru negoli sa svakodnevnim poslom i teretom te ozbiljnošću koja dolazi iz tog posla. Značenje igre kao arhetipskog simbola života postaje nam jasno kad ju objasnimo koristeći neke osnovne oblike igre. ${ }^{191} \mathrm{Iz}$ obilja mogućnosti koje se ovdje nude Welte odabire tri oblika igre kao predstavnike najvažnijih oblika mogućih igara. Naime, to su igre na sreću, borbena igra i čisto igranje. ${ }^{192}$

\subsection{Pitanje i problematika igara na sreću}

\subsubsection{Uvodna razmatranja o sreći općenito}

Pojam sreće te s njom povezanih sličnih stanja, poput zadovoljstva, uživanja itd., neodvojiv je od etike. ${ }^{193} \mathrm{O}$ njoj se kroz povijest misli promišljalo s pozicije moralno ispravnog, odnosno neispravnog, dobrog, odnosno lošeg. Čovjek oblikuje svoj život te se shodno tomu ostvaruje upravo u perspektivi vlastite sreće imajući svakako na to pravo štoviše, i svojevrsnu obvezu. ${ }^{194}$ Već je ovdje dakle u svojevrsnoj obvezi oblikovanja vlastita života uočljiva etička komponenta: nismo darovani životom da se s njim ophodimo

\footnotetext{
${ }^{190}$ Usp. Isto, str. 252.

${ }^{191}$ Usp. Isto, str. 253.

${ }^{192}$ Usp. Isto, str. 253.

${ }^{193}$ Usp. KORFF W., Wie kann der Mensch glücken? Perspektiven der Ethik, München - Zürich, 1985., str. 388.

${ }^{194}$ Usp. KOPREK I., Sreća i igre na sreću. Etički okvir za razumijevanje jednog fenomena današnjice, str. 368.
} 
neodgovorno i olako. Promatrano na razini životnog iskustva, jasno se uočava da svaki čovjek teži za srećom. O sreći ili blaženstvu razmišljali su mnogi filozofi te književnici, pjesnici i teoretičari općenito tijekom duge povijesti misli. Tumačili su je na razne načine: s jedne strane kao onu koja je ovisna o sudbini, odnosno naklonosti „bogova“, dok s druge pak strane pojedinac može (i treba) na nju utjecati, što znači da je za svoju sreću odgovoran. ${ }^{195}$ Ona se, štoviše, ostvaruje uz poticaj čovjeka pri čemu je, jasno, njegova nakana presudna. Welte na više mjesta u svojim promišljanjima o osobi spominje Hegela koji pomalo pesimistično tvrdi kako povijest svijeta nije pogodno tlo za ostvarivanje sreće. ${ }^{196}$ Epikur, kojeg Welte također spominje, sreću je poistovjećivao s odsutnošću boli i zadovoljavanjem potreba koje čovjeka čine sretnim. ${ }^{197}$ I Nietzscheu je bilo stalo do pitanja o sreći. On se pita sljedeće: „Što čovjek treba činiti da bi izrekao da životu, da bi svaki trenutak živio tako da bi se mogao doživjeti sretnim?“198

Već je dobro poznat Nietzscheov govor o moralu stada i nadčovjeku koji bi trebao prevrednovati sve vrednote koje su do tada bile općevažeće da bi se postigla istinska sreća i zadovoljstvo. Nietzsche se radikalno opirao kršćanskim vrednotama i s njima vrlinama koje kršćanstvo smatra važnima te ih određuje kao dobre i poželjne. Nasuprot kršćanskim vrlinama kojima je, po njemu, prvotni cilj „obuzdavanje“ životnog i snažnog u nama, filozof nihilizma kao ideal te ujedno put postizanja sreće i zadovoljstva nudi sasvim suprotno: »Prvi učinak sreće jest osjećaj moći: ona će sebe očitovati, bilo spram nas samih, ili spram drugih ljudi, ili spram predodžbi, ili spram zamišljenih bića. Najuobičajeniji načini njezina očitovanja jesu: darivanje, izrugivanje, uništavanje - svo troje iz zajedničkog im osnovnog nagona.«199 „Osnovni nagon“ za Nietzschea predstavlja život koji uvijek ostaje samo pokušaj ili rizik. Život se pak u tom pogledu nužno vezuje uz sreću, odnosno pojam (punine) života te $u$ isto vrijeme i predstavlja pojam sreće. I obratno, kada nas prati sreća, tada velimo da „dišemo svim plućima“, odnosno živimo život u svim njegovim aspektima. Ta punina, kako to izvrsno uviđa Nietzsche, u nama rađa i osjećaj moći: odvažujemo se na mnoge čine, to jest djelatnosti za koje smo sposobni tek kada nas prati taj doživljaj. Međutim, Nietzsche je svjestan svih posljedica ove „punine“ života i s njom vezane moći te izvrsno zaključuje da se sreća, jer se

\footnotetext{
195 Usp. Isto, str. 369.

196 Usp. HEGEL G. W. F., Vorlesungen über die Philosophie der Geschichte, Philipp Reclam, Leipzig, 1910., str. 70-71.

${ }^{197}$ Usp. KOPREK I., Sreća i igre na sreću. Etički okvir za razumijevanje jednog fenomena današnjice, str. 368.

198 Usp. SIMM H. J., Formel meines Glück. Aus Friedrich Nietzsches Werken und Nachlass, Insel Verlag, Frankfurt, 2001., str. 11.

${ }^{199}$ Usp. NIETZSCHE F., Morgenröte. Gedanken über die moralischen Vorurteile, ur. Borken T., Henricus, München, 2019., str. 352.
} 
redovito traži i zahtijeva radi nje same, očituje u darivanju, izrugivanju, uništavanju, pri čemu, jasno, pojam darivanja ovdje nema nikakvo moralno-etičko značenje, već bitno antropološko $\mathrm{i}$ to $\mathrm{u}$ jednom podsvjesnom smislu: svega se odričemo, to jest svesrdno darujemo (i ono što ne bismo trebali) samo da bismo bili sretni. Ili drugim riječima rečeno, ljudi u postizanju sreće redovito ne prežu ni pred čim da bi je se dokopali. Razmišljanje o sreći zaključuje i I. Koprek kada ističe da se diktat sreće pokazuje kao paradoks suvremenog društva i oni koji mahnito hrle $\mathrm{k}$ sreći često ostaju bez nje. ${ }^{200}$ Mahnito traganje za srećom ljude čini takvima da postaju igrači (vlastite) sreće. To pak rađa nemalim problemima jer se povećanjem „uloga“ ujedno povećava i rizik njezina postizanja. Ljudi suvremenog doba često postaju igrači sreće jer žive rizik potrage za srećom. ${ }^{201}$ To nas vodi do sljedeće teme kojoj se Welte, zbog njene raširenosti, također posvetio - igre na sreću i njihove posljedice za istinsku sreću. ${ }^{202}$

\subsubsection{Igre na „sreću“ i njihove posljedice za istinsku sreću}

Igre na sreću vrlo su popularne od davnina do danas. U njima naša vještina, to jest umijeće samog čina ,igre“ igra malu ulogu dok je mnogo više na djelu ono što nazivamo samom srećom. Welte uzima kao primjer igru s kockom gdje ne možemo osobito utjecati na pad kocke na određenu stranu. Ako bi netko želio probati namjestiti igru s kockom, tada bi igra bila lažirana i ne bi se računala kao valjana, pogotovo ne kao poštena igra. Ovdje prepoznajemo na paradoksalan način da igra kockom također ima određene zakone i pravila. Prema Welteu, glavni zakon igre na sreću jest taj da bi „sreća uvijek trebala/morala biti sreća““ ${ }^{203}$ U načelu ona ne bi smjela biti predodređena, isprovocirana ili na bilo koji drugi način unaprijed kontrolirana. U tome se dade iščitati uzbuđenje s obzirom na igre na sreću kao što je igra s kockom. Radi se o totalnoj „otvorenosti““. Na tragu rečenog, pojam za „,igru na sreću“ oduvijek se vezao, štoviše, u kolokvijalnom govoru i upotrebljavao, izričaj kockanje, pri čemu biva očito da se radi o o mogućnost ulaganja nečeg materijalnog. Osoba stavlja nešto na kocku te može osvojiti kako taj ulog, tako i ulog svojih suigrača, kao što u suprotnom može i sve izgubiti: poanta je upravo u ,sreći“ dobitka.

\footnotetext{
${ }^{200}$ Usp. KOPREK I., Sreća i igre na sreću. Etički okvir za razumijevanje jednog fenomena današnjice, str. 373.

${ }^{201}$ Usp. Isto, str. 373.

202 Usp. WELTE B., Gesammelte Schriften Person I/1, str. 253-255.

${ }^{203}$ Usp. Isto, str. 253-255.
} 
Na ovom se mjestu opet postavlja pitanje što je to uopće sreća i kako ju tumačimo. Welte je mišljenja kako sreću u svakodnevnom životu shvaćamo kao svojevrsni usud, događanje kroz koje ne možemo svojevoljno proći, odnosno ono na što ne možemo utjecati i što „samo po sebi odlučuje“ hoćemo li pobijediti ili izgubiti u određenoj igri ili pak radnji općenito. Taj vid „odluke“, štoviše svojevrsne „,samovolje“, hoće li nam se sreća „osmjehnuti ili ne“ jest doživljaj koji ljude u poigravanju sa srećom (kockom) redovito prati. Ipak, i onkraj toga se svojevrsna strast, kao i uživanje u igri, ovdje ne može zanijekati. S druge strane pojedinac se može i zabrinuti, štoviše pasti u tešku krizu, i to se redovito događa kada ga sreća ne „pohodi“, pogotovo kada je novac u pitanju, no po sebi to nije presudni element igre kao takve. Poanta je igre, s ulaganjem ili bez njega, njezina rasterećenost redovitim, strukturalnim, ograničenim, stoga ju upravo to čini onim što uistinu jest: puko igranje. U tom je smislu sastavni dio igre, prema Welteu, taj da možemo prihvatiti biti i dobri gubitnici jer uvijek netko (nešto) pobjeđuje pri čemu „uvijek“ ne moramo biti mi. Štoviše, ako je prava igra u pitanju, to i ne treba biti. Stoga kao i dobitak, tako je i gubitak bitna sastavnica igre koji je u antropološkom i svakom drugom smislu puno kompleksniji negoli tek dobitak: gubitak može biti drugo mjesto, djelomično dobivanje ili jednostavno sudjelovanje bez pobjede. Nikako ne treba smetnuti s uma da se pojam igre i sreće redovito veže uz ,igre na sreću“.

Razmatrajući razumijevanje sreće i s tim vezano igara na sreću, I. Koprek polazi od činjenice da svaki čovjek prema svojoj naravi teži postizanju sreće, nastoji biti ispunjen i zadovoljan. ${ }^{204}$ Problem se tim više produbljuje što je sreća u današnje vrijeme nešto što se posvuda nudi tako da je lako dohvatljiva - treba samo izbrati taj put koji se predlaže. S druge strane sreća se suvremenom čovjeku postavlja kao zahtjev koji treba dosegnuti te on, ako ga ne ispuni, postaje gubitnik. ${ }^{205}$ Prisilna i nametnuta sreća čini čovjeka nesretnim samo zato što teži postići to što mnogi imaju te on, uspoređujući se, ne uviđa da za njega taj oblik sreće nije ni naravan ni primjeren. Čovjek se zbog toga ,igra sa srećom“ te posebno u igrama za sreću stremi velikom dobitku, ostajući pri tome redovito nesretan.

Nadalje je iznimno važan i sljedeći element u igrama na sreću: strast i s njom užitak koji prati iščekivanje i nagnuće k dobitku. Upravo su zbog toga ovisnosti o igrama na sreću, klađenju i svim drugim oblicima hazarderstva, uz ostale opijate, poprimile oblike suvremene (psihološke) pandemije. Pojedini autori izvrsno detektiraju kako u igrama na sreću navodna sreća ili kockarska kombinatorika postaje presudna za uspjeh u životu, a ne vlastita marljivost

\footnotetext{
${ }^{204}$ Usp. KOPREK I., Sreća i igre na sreću. Etički okvir za razumijevanje jednog fenomena današnjice, str. 367. ${ }^{205}$ Usp. Isto, str. 367-377.
} 
i pošten rad. U tom smislu navedena kombinatorika postaje etički opasna stvarnost prisutna u životu osobe koja se okušava u igrama na sreću. ${ }^{206}$ Valja ovdje posebno obratiti pozornost na (netom spomenuto) potpuno pogrešno tumačenje uspjeha koje (tumačenje) držimo iznimno važnim jer navedeni autor raskrinkava svu patologiju veze „igra na sreću - uspjeh“. Kada se, naime, stekne novac igrama na sreću, to nije nikakav uspjeh niti pravi dobitak, nego je, osim što je krajnje etički upitno, ono dugoročno gubitak jer samo još više mami, to jest stvara ovisnost. Osim pogrešnog shvaćanja uspjeha u igrama na sreću također se sasvim pogrešno shvaća i kršćanska vrlina nade. ${ }^{207} \mathrm{U}$ tom smislu I. Koprek ističe, a s obzirom na odnos nade $\mathrm{i}$ igara na sreću, sljedeće: „Igre na sreću su suprotne nadi, svojevrsna patologija nade i ostaju uvijek etički dvojbena praksa. Često puta premašuju granice dobrog ukusa i postaju ozbiljna igra, a ne više zabava za pojedinca koji igra takve igre na sreću ${ }^{e e}{ }^{208}$ Etički dvojbena praksa u smislu da je cilj isključivo ono materijalno ponad svih drugih vrijednosti, kao i puka strast za igrom pri čemu je ovdje jedini kriteriji „dobitak“. Osoba doslovno zaboravlja na sve drugo i „trčiee za materijalnim i dobitcima koji ju u konačnici čine nesretnom.

Welteu se to čini kao da se ljudi vole igrati sa srećom, vole izazivati sreću, stoga je posebno zanimljivo vidjeti zašto je tomu tako da se toliko mnogo ljudi voli (po)igravati kroz sreću s vlastitim životom. Odgovor na to pitanje ide u smjeru kako igra na sreću zapravo predstavlja sveobuhvatan simbol života. ${ }^{209}$ Tako je, za većinu ljudi, ono što se događa u životu stvar sreće i okolnosti koje su se posložile na ovaj ili onaj način te ih redovito promatramo kao sretne ili pak kao one koje su izmakle sreći te ih označavamo kao nesretne. Ako dublje pogledamo na sam život, ljudsko shvaćanje, okolnosti koje nas okružuju i utječu na stvarni život, tada nam se one doista predočuju kao slučajnosti: događaju se na tako da pojedinac zaista na njih nema utjecaja. U tom smislu, a što se tiče već i samog početka ljudskog života, činjenica je da osoba ne izabire svoje roditelje, a time ni kombinaciju svojih genetskih čimbenika, već je to svojevrsna prva od igara sa srećom koja je presudna za njezin cijeli život jer je osoba upravo tako prvo određena. ${ }^{210}$ Nakon te prve igre sa srećom osobu kroz život dočeka još ponešto slično ovom: osobe međusobno susreću jedna drugu „slučajno“, pri čemu se često iz svih tih slučajnosti, to jest nenamjeravanih, slučajnih susreta događa nešto presudno za život i postojanje dotične osobe. Osoba ulazi u ovu ili onu sudbinu, kao što

\footnotetext{
206 Usp. Isto, str. 367.

207 Za razliku od nade, mi smo netom prije hazarderske igre na sreću upravo povezali sa strašću, nagonom, pretjeranim očekivanjima koja upravo zato što su takva rađaju ovisnošću i nemaju nikakve veze s krepošću nade. ${ }^{208}$ KOPREK I., Sreća i igre na sreću. Etički okvir za razumijevanje jednog fenomena današnjice, str. 367.

${ }^{209}$ Usp. WELTE B., Gesammelte Schriften Person I/1, str. 254.

${ }^{210}$ Usp. Isto, str. 254.
} 
je bračna zajednica, ali i postaje primjerice ekonomist, političar ili odabire neko drugo zanimanje ili pak na poticaj i nagovor odlazi živjeti na ovo ili ono mjesto. To ostavlja dojam kako osoba, koračajući kroz život, biva izručena svojevrsnoj sudbini koja joj pak određuje put, odnosno život uopće.

Ipak, promatrajući na razini same fenomenologije života, to jest s obzirom na stavove i ponašanje ljudi u svakodnevici, Welte uočava kako se osobe ne žele olako prepustiti onom čemu su, doduše, već izručene - materijalnom, to jest biološkom i povijesnom naslijeđu, odnosno sudbini kao takvoj, te život nastoje usmjeravati, odnosno bitno oblikovati prema vlastitom nahođenju. To se usmjeravanje prvenstveno sastoji u tome što osoba pokušava unaprijed programirati svoj život i sudbinu koristeći razne mogućnosti (modernog) života. No ono što je presudno za svaki pojedini život i od čega pojedinac ne može pobjeći pokazuje upravo to kako je život osobe u tim okolnostima od početka do kraja svojevrsna igra. Ipak, vrijedno je to, kako smo spomenuli, što u toj životnoj igri pojedinac ulaže ništa manje do život u cjelini kako bi živio što kvalitetniji i bolje osmišljen život i svoju sudbinu. Welte je mišljenja kako je za tu životnu igru potrebna upravo hrabrost i s njom odlučnost da čovjek ne bi bio potpuno izručen igri, odnosno sudbini života. ${ }^{211}$

Očito smo stvoreni tako da volimo igru sreće i rado se u nju uključujemo, iako nam to sa sobom nosi i određene rizike, a ulozi koji se mogu dobiti ili izgubiti dosta su visoki. Stoga ono što je potrebno shvatiti prilikom igre na sreću, koja obilježava cijeli život osobe koja se u nju uključuje, jest - slično kao i kod (spomenute) igre uopće - da trebamo prihvatiti i to kako možemo biti dobri gubitnici ako to bude potrebno. Da bi se to razumjelo, Welte navodi kako je potrebno razumjeti teološku pozadinu ove naizgled neteološke igre na sreću. ${ }^{212}$ Naime, sigurno je to da nećemo uvijek uspjeti ostvariti svaki namjeravani cilj svojeg života. Štoviše, i više je nego dobrih primjera osobnih života gdje osobni gubitak, ili pak nesreća bilo koje vrste, postaje sjeme promjene vlastitog življenja ili, konkretnije, sama patnja mnoge ljude na takav način promijeni da učine zaokret u kvaliteti vlastita života. No usporedba života s igrom u teološkom pogledu zanimljiva je jer nas može naučiti da u stvarnom životu, kako je već spomenuto, možemo biti i dobri gubitnici, odnosno i u ovom pogledu da gubitak može biti smislen. Pri tome posebno mislimo, s Welteom, na stanja boli i patnje s kojima smo suočeni, za koje pak doživljavamo da su se bez ikakvog, ,razloga“ i slijedom nespretnih i nesretnih okolnosti dogodili. Svakako je, osim patnje, Welteu u primisli i druga vrsta neuspjeha s

${ }^{211}$ Usp. Isto, str. 254.

${ }^{212}$ Usp. Isto, str. 254-255. 
kojima smo suočeni u svakodnevici. U tom se smislu freiburški teolog trudi pokazati da $\mathrm{u}$ kontekstu života ispunjenog sretnim i manje sretnim trenutcima upravo neuspjeh može upotpuniti i obogatiti život osobe tako da ona prihvati svoj život u potpunosti - i s uspjehom i S neuspjehom jednako te nauči biti ,dobar“ gubitnik na tom putu. ${ }^{213}$

Ipak, ako većina ljudi sreću zamišlja kao puku slučajnost, tada se postavlja legitimno pitanje postoji li odlučujući čimbenik u njihovu životu da im oni (životi) krenu u ovom ili onom smjeru. Je li to samo puka slučajnost usporediva s pojmovima sreće i igre!? Pitanja koja smo ovdje naznačili, a kojima se iscrpno bavio i sam Welte, pogađaju u srž ljudske egzistencije pri čemu odgovor nikako ne može biti jednoznačan. Štoviše, u kojem god smjeru krenemo, zalazimo u nemale poteškoće. Ako je, naime, odgovor na postavljeno pitanje pozitivan, tada sam ljudski život svodimo na slučajnost, odnosno činimo ga ovisnim o njoj. S druge pak strane, izuzimajući egzistenciju od njezine otvorenosti, odnosno mogućnosti, te ju svodeći na činjenicu ovisnosti, odnosno „dirigiranja“ sa strane (ma tko to bio), dopuštamo svojevrsni determinizam, suprotan ljudskoj slobodi. Ipak, kako je bilo i za očekivati, Welte se približava drugom odgovoru s bitnom naznakom da se ovdje ne radi o determinaciji, već izvjesnom „providonosnom vodstvu“. Tako ipak, ako nam (osobni) život djeluje kao slijed pukih slučajnosti, uočavamo da i iznad nje, kao i sreće prema kojoj žudimo, mora postojati neka konačna, smislena i racionalna Osobnost koja svim ravna, s ovim svijetom istina povezana, međutim, u osnovi, potpuno neovisna o njemu. I dalje se radi, prema Welteu, o nebeskoj stvarnosti koja bdije nad svakom osobom tako da se u sreći s radosnima raduje, a u gubitku sa zaplakanima plače (usp. Rim 12,15). I više je nego uočljivo da Welte ovdje ističe božanskog Boga koji ljudski život ne želi promatrati (i voditi) pod strogim matematičkim jednadžbama, dakle determinirano, već dopušta da ljudski život uistinu bude „kreativna igra“, no postavljajući sebe iznad te same igre, kao i sreće. Ovdje naš filozof pravi usporedbu sa starim Rimljanima koji su sreću nazivali „Fortuna Primigenia““, 214 to jest prvorođena kći nebeskog boga. Njoj su različiti časnici, političari, velikodostojnici, kao i ostali puk, prinosili darove za posvetu prilikom odlaska u neke životne borbe. To je, prema Welteu, bila jedna bogobojazna rimska filozofija života koja puno govori o životnoj igri na sreću u okviru ljudskog postojanja. Međutim, iako su se prema njoj odnosili sa strahopoštovanjem, moleći da

\footnotetext{
${ }^{213}$ Usp. Isto, str. 255.

214 Fortuna (lat. sudbina, kob, sreća), starorimska božica sreće i dobra ili loša udesa. Okeanova kći, poistovjećena s (možda starijom) rimskom božicom sretnog slučaja Fors i grčkom božicom Tihe. Njezin je kult po predaji uveo u Rimu kralj Servije Tulije i sazidao joj prvi hram. Smatrana je nestalnijom od svih bogova; razdavala je svoje darove naslijepo, pa su Rimljani svim sredstvima nastojali steći njezinu naklonost i podizali joj više hramova i kipova nego drugim bogovima, u: Hrvatska enciklopedija, mrežno izdanje. Pristupljeno 8. 10. 2020. Dostupno na: http://www.enciklopedija.hr/Natuknica.aspx?ID=20200
} 
na njoj participiraju, ipak su stari Rimljani shvaćali da je svaki čovjek s druge strane „kovač svoje sreće“. U tom smislu, koliko god izložen igri života, čovjek, prema njima, ima trajnu zadaću nastojanja, odnosno dužnost „iskovati“ svoju vlastitu sreću. Kovati pak vlastitu sreću čovjek može uz pomoć vrline, virtus, koja je za Rimljane bila vrlo važna. Prema rimskom pogledu na uspjeh u životu, vrlina je bila iznimno cijenjena, posebice ona stoička (pomalo vojnička), poput hrabrosti, inteligencije, ustrajnosti, to jest izdržljivost, svakako uz pretpostavku da će kći bogova, sreća, skrenuti svoj pogled na njih i u tom smislu kao dar neba dopuniti ono što čovjek svojim snagama nije u stanju.

Vrlina (lat. virtus, grč. arete) je moralna izvrsnost osobe. Ona je jedan od osnovnih pojmova etike još od antičke filozofije. Četiri stožerne, odnosno glavne vrline jesu mudrost, pravednost, hrabrost (postojanost) i umjerenost. Prema Aristotelu, kojeg Welte na nekoliko mjesta u svojem promišljanju o osobi spominje, vrline se dijele na etičke (karakterne) i dijanoetičke (umske) ${ }^{215}$, dok je svrha ljudskog djelovanja te postojanja uopće život provoditi u skladu s vrlinama. Aristotel velebno razvija svoju teoriju vrlina koja je ujedno etika i antropologija. Antropološki karakter njegove teorije vrlina očituje, zanimljivo, njezinu kompatibilnost sa suvremenim ne samo filozofsko-etičkim već i psihološkim teorijama i pravcima. Naime, teorijom vrlina grčki filozof razvija jednu antropologiju izvrsnosti koja je u potpunosti u okvirima onog ljudskog, pri čemu on odbacuje svaku radikalnost. Vrlina je stanje, i to stanje sredine koje nastaje u „suigri“ uma i osjećaja. Tako je ono što suvremena psihologija naziva ekvilibriji prema Aristotelu život u vrlinama - što znači prema istinskom logosu, redu, ustroju, konačno harmoniji. Prema stoicima je pak vrlina jedino bezuvjetno dobro prema kojem se čovjek mora stalno približavati. Vrline tako stoicizam te dalje rimskohelenistička filozofija, za razliku od Aristotela koji im ipak daje „dušu“, promatra više u vidu vježbe protiv sjetilnosti i nagnuća, pri čemu su one zadužene za osiguranje nepomućenosti i apatije. U tom smislu ne treba čuditi da je upravo stoička filozofija bila iznimno bliska pojedinim rimskim vojskovođama poput Marka Aurelija. Kršćanstvo pak, koje je temeljno za razumijevanje Welteove fenomenologije religije i promišljanja o osobi, u vrlini promatra pomoć u ispunjanju Božje volje na zemlji koju On ima s pojedincem dodajući, jasno, tim četiri stožernim vrlinama tri bogoslovske, to jest teologalne: vjeru, ufanje i ljubav.

\footnotetext{
${ }^{215}$ Etičke se vrline, prema Aristotelu, odnose na nerazumni dio duše, različite su od dijanoetičkih vrlina koje se odnose na njezin razumski dio. Etičke se vrline stječu odgojem i navikama; među ostalim one su postojanost, umjerenost, sloboda, velikodušnost, skromnost, istinoljubivost, u: Hrvatska enciklopedija, mrežno izdanje. Pristupljeno 14. 10. 2020. Dostupno na: https://www.enciklopedija.hr/Natuknica.aspx?ID=65516
} 
Kratak presjek govora o vrlinama imao je za cilj dodatno osvijetliti Welteovu koncepciju „traganja za srećom“ u ,igri života“. Iako se, naime, doima kao da se radi o pukoj igri, životu ipak nismo potpuno izručeni da nas se ne bi ništa pitalo. Upravo suprotno: Božje providonosno vodstvo svakog stvorenog čovjeka uključuje u bitnome čovjekov angažman i sve što mu u tom angažmanu služi kao pomoć, poput već spomenutih, stečenih vrlina. Ljudske snage, međutim, prema našemu filozofu religije, nisu dovoljne, već moraju biti nadopunjene vjerom, odnosno milosti koje se, među ostalim, očituju, kako ćemo vidjeti, u onom što Welte naziva izvršenje religije. Vrline se ovdje dakle promatraju u specifično kršćanskom smislu kao karakterne dispozicije, obogaćene i nadopunjene darom vjere, odnosno milosti.

Welteovo intrigantno bavljenje srećom i s njom povezanom igrom možemo, u okviru zaključnih analiza, promotriti u kontekstu onog što on sam navodi kao primjer - Rilkeove pjesme naziva Ljubavna pjesma. Rilke se u svojoj pjesmi pita »koji ovo svirač sve nas drži«? Welte smatra kako slika pokreta gudala u Rilkeovoj Ljubavnoj pjesmi te igra dvoje ljubavnika jest dobar prikaz kako je to igra puna mogućnosti, prilika i dobitaka, kao i gubitaka i opasnosti koje su nadolazeće u igri života. Welte ukazuje na to kako su pjesnici i književnici igru promatrali bitno dvoznačno i tako najtočnije: kao dobitak i gubitak istovremeno. Zato što je sve tako skriveno i ne možemo ništa unaprijed znati u igri života, Welte se također vraća i Meisteru Eckhartu ${ }^{216}$ i njegovom načelnom stavu kako se treba prepustiti životu i onom kamo nas on vodi, oslobođeni čvrstih uporišta u željama i prohtjevima, svakako uz temeljno (razborito) planiranje života i budućnosti, te pri tome ostati u pouzdanju u dobroj i ,teškoj sreći“. Welte pojmom „teška sreća“e (slično kao i „dobri gubitnici) želi ukazati na to da život osobe nije uvijek pozitivan te da osoba nije na dobitku u svakom trenutku svog života, no razumijevajući život kao igru koja donosi kako pozitivno, tako i negativno, i s pouzdanjem da će nakon „teške sreće ee opet nastupiti ona „dobra sreća ${ }^{\text {ee }}$, naš filozof religije očituje jednu otvorenost životu i budućnosti.

Prema zaključku: valja ponoviti da je igra, kakva god bila, oduvijek vrlo zanimljivo područje kako na religijskom planu, tako i na svim drugim sferama čovjekova života. Zato se Welte upravo osvrće na pitanje igre u okviru ljudskog postojanja, posebice igara na sreću, uz koje se, s pravom, redovito veže negativan prizvuk jer osoba jednostavno nije u stanju racionalno procijeniti što je to igra, a što prelazi u sfere koje se mogu nazvati jedinim pravim nazivom - bolest (ovisnost). Igre na sreću oduvijek idu uz ljudski rod, služile su za zabavu i

\footnotetext{
${ }^{216}$ Odnosu Weltea prema M. Eckhartu posebno se posvećujemo u drugom dijelu ovog rada.
} 
opuštanje, no uvijek se isticala važnost zadržavanja trezvenosti i ozbiljnosti da igra, poglavito natjecateljska, ne bi prešla u totalnu kaotičnost i time nasilje. Jer igra koja premašuje granice zabave i opuštanja može biti vrlo opasna ne samo za osobu već i zajednice u kojima se osoba trenutno nalazi. Treba također reći kako je kršćanska tradicija stjecanje dobitaka i novca igrama na sreću i kockanjem oduvijek promatrala prijekorno, štoviše, kao izvor grijeha i đavolskog izuma upravo zbog njihove razornosti za pojedince i obitelji. Stvarnost igara na sreću i kockanja ni danas nije ništa manja, štoviše, postala je, nažalost, još ekscesivnija.

Konačno, služeći se Welteovim riječima, možemo reći kako je u ljudima usađen nagon za rizikom pri čemu se osobe u kontekstu čitavog života igraju sa slučajnošću koju žude i od koje istovremeno i strahuju. Ali u cjelini je to zapravo više ljubav i otvorenost, štoviše, želja za avanturom spram života koja je mnogo veća od straha na koji osoba može naići. To je igra iznad koje blista skrivani sjaj igrača koji igra. ${ }^{217}$ Čini se da je to tajna rizika igre (pa i igara na sreću) u kojima ljudi toliko uživaju. Osim pak otvorenosti i avanture, arhetip igre je i u tome da ona u sebi sadrži nešto bitno natjecateljskog. To je predmet naših sljedećih razmatranja.

\subsubsection{Natjecateljske $i$ borbene igre}

Borbene igre jesu igre druge vrste kojima se Welte bavi u svojem promišljanju o osobi i ljudskom postojanju. Sreća igra u izvjesnom smislu ulogu i u ovim igrama, ali odlučujući faktor jest borba, to jest napor suparničkih protivnika za uspjeh, odnosno rezultat same igre. Welte je stoga mišljenja kako sreću u ovim igrama treba isključiti što je više moguće kako bi ljudi neopterećeni usudom predodređenosti mogli ući u igru i vlastitom snagom i vještinom nešto postići. U tom su smislu borbene igre čista suprotnost igrama na sreću. U ovim se igrama ljudi služe prvenstveno svojim vlastitim snagama i vještinama, a manje srećom. Dakle ono što se događa u tim igrama u prvi plan donosi ljudsku namjeru koja nastoji predodrediti rezultat, odnosno okrenuti ishod u svoju korist, što je pak potpuno legitimno. Upravo taj vid proračunatog ophođenja i planiranja u igri očituje dubine ljudskog postojanja kao takvog. Naročito se, prema Welteu, nogometna igra može smatrati pravim i stvarnim modelom za sve vrste borbenih igara. U tom smislu igra po sebi nije ni politički ni ekonomski događaj. $\mathrm{Ne}$ koristi se za regulaciju životnih struktura, nego je to samo i uvijek tek igra. Igra uvijek treba ostati izvan toga (politika, ekonomija) da bi zadržala svoju nepatvorenost i čistoću. Zbog toga Welte ističe, koliko god život uspoređivali s igrom, da nam upravo navedena područja

\footnotetext{
${ }^{217}$ Usp. WELTE B., Gesammelte Schriften Person I/I, str. 255.
} 
pokazuju (politika, ekonomija) kako je jedno red koji vlada u ovim područjima stvarnosti, a drugo red igre, i to svakako treba ostati odvojeno.

Obje vrste igara, one na sreću kao i ove natjecateljske, očituju - prema Welteu arhetip ljudskog ponašanja koji proizlazi iz dubina ljudske svijesti. Obje očituju, kako je dijelom i naznačeno, strast, zanos, napor koji se pri tome primjenjuju - prva u „prizivanju“ sreće, druga u predodređivanju i planiranju konačnog rezultata. Također i jedna i druga (iako je to kod natjecateljske, to jest borbene igre mnogo više slučaj) također očituju svojevrsno udruženo $^{218}$ djelovanje kako bi se postigao neki zajednički cilj. I iz ovog djelovanja proizlaze simboličke slike života. Natjecateljska je igra povezana sa stvarnim životom tako što se iz arhetipskog otiska razvija simbol koji izražava nešto što ljudi uvijek žele vidjeti i iskusiti u ljudskom ponašanju - zajedništvo za istu stvar, trud, napor i konačno borbenost, a koje inače nikad ne stignu vidjeti iznutra. Zbog toga natjecateljsku igru, ma kakva ona bila, gledamo uvijek kao fascinantan simbol poretka koji je uvijek namjeravan i željen i koji se diže iz dubina ljudske prirode i budi natjecateljski duh u čovjeku, bilo kao akteru ili promatraču. To objašnjava da svaka natjecateljska igra (atletika kao kraljica sportova, zatim gimnastika, plivanje, vaterpolo, košarka, rukomet, tenis te svakako nogomet i dr.) utječe na toliko milijuna ljudi, iako one često nisu razumne u smislu svakodnevne stvarnosti. ${ }^{219}$ Ono što ove natjecateljske igre simbolično prikazuju jest život u njegovom svjesnom razvoju i njegov namjeravani i željeni oblik kao natjecateljska suradnja. Upravo su zato navedeni primjeri sportova više u pozornosti javnosti negoli bilo koja igra (na sreću).

Nadalje borbena, natjecateljska igra u svojoj osobitosti pokazuje svoj poseban odnos s mitom. U mitu se govori o jedinstvenom događaju kao simbolu onog što se uvijek i iznova događa. U borbenim se igrama svaka pojedinačna igra promatra kao ona koja je vrlo važna i vrlo značajna za obje suprotstavljene strane. Sve dok su važne i dok se oko njih obje strane zauzimaju s ogromnim naporom i angažmanom, one imaju smisla. Spomenutu mitološku karakteristiku natjecateljskih, to jest borbenih igara (kao, uostalom, i drugih timskih sportova) Welte prepoznaje zbog dimenzija koje su u njih uključene, poput vjere u zajedničku stvar bila ona opravdana ili ne - zajednički tim koji pojedinci sačinjavaju, uspjeh, to jest željeni ishod kojem svi zdušno teže te već spomenute vrline koje u njima posebno dolaze do izražaja, poput ustrajnosti, upornosti, izdržljivosti itd. Mitološki aspekt svoj najočitiji odraz dobiva u

\footnotetext{
${ }^{218}$ Za razliku od Welteova doba i onog što se označavalo pojmom ,igre na sreću“, odnosno kockanja (primjer kartanje), općenito su danas one postale potpuno individualizirane, samotnjačke, primjer su za to automat klubovi.

${ }^{219}$ Usp. Isto, str. 256-257.
} 
trenutcima kojima i sami svjedočimo: navijači se, to jest navijačke skupine (često i igrači) fizički obračunavaju, štoviše, stradavaju iako su i sami svjesni da igra nije nešto presudno za život, odnosno kao situacije u kojima smo postavljeni da se zaista borimo za život.

Ako se dakle osvrnemo na njezin temeljni sadržaj, sama se natjecateljska igra odvija kao borba. Dvije sukobljene strane natječu se za pobjedu i svaka ju želi osvojiti. To stvara niz stalno novih sukoba i sukobljenih situacija. Kako će se borba završiti, svaka od sukobljenih strana sama određuje svojim vještinama i željom za pobjedom te se završetak ne može unaprijed sa sigurnošću reći, odnosno (pred)odrediti. Upravo je to ono što svaku pojedinu utakmicu košarke, rukometa, vaterpola, nogometa itd. čini uzbudljivom. Pobjednik se takvim, naime, kao pobjednik mora dokazati u sukobu. Sama je borba po sebi igra, ali unutar borbene igre bori se s ozbiljnošću, čak i sa strašću te uz upotrebu sve snage i svake vještine. Dakle to je prava borba, iako u igri. Kada bi na djelu bilo suprotno, naime, ,igra bez borbenosti““ (šah samo naizgled isključuje borbenost, no ona je itekako prisutna, samo ne na onaj očit fizički način), igra bi bila dosadna i izgubila bi svoju suštinu - svoj arhetipski i mitološki karakter, a time i svoju fascinaciju, smatra filozof religije. Takva se borba sa svojim sukobima može nazvati i borbom rivalstva. Ako ovo također uzmemo arhetipski, simbolički i mitološki, onda bi to moglo značiti sljedeće: ljudi su u osnovi na bojnim poljima rivalstva s vlastitom vrstom te svim mogućim sukobima koja ta rivalstva uključuju. Ljudi uvijek imaju protivnike i važno je boriti se za pobjedu i postići ju samim korištenjem snage i vještine protiv protivnika. Uzbudljiva je stvar u životu oko toga tko izlazi kao pobjednik jer se to, jasno, ne može i ne smije znati unaprijed, nego tek poslije završene igre. U tome i jest najuzbudljiviji dio borbene igre iako je u načelu ista tijekom čitave povijesti, to jest od kada se počela igrati. Welte je mišljenja kako mnogi gledatelji upravo kroz utakmice, to jest natjecanja promatraju vlastiti život kao simbol igre. To dobrim dijelom objašnjava njihov interes za navedene sportove. Za razumijevanje netom spomenutog života to znači sljedeće: kako borba suparnika, odnosno rivala u njihovim sukobima nikad nije u potpunosti eliminirana, isto je i s konkretnim životom - u svakodnevici se, posebno radnog mjesta, odnosno posla koji općenito obavljamo, neprestano susrećemo sa svojevrsnim ,neprijateljima“, odnosno nalazimo se u rivalstvu i borbi iz kojih nastojimo (već i podsvjesno) izaći kao pobjednici. Dakle situacije se završavaju ili pobjedom ili porazom (rjeđe neriješeno) te se ponavljaju u nekoj novoj prilici. Taj doživljaj ljude prati gotovo svakim odlaskom na radno mjesto. Welte će reći kako upravo igra uči kako postoji horizont legitimnog sukoba. ${ }^{220}$ Tome u prilog govori činjenica da se rivalstva razvijaju

\footnotetext{
${ }^{220}$ Usp. WELTE B. Isto, str. 257.
} 
i na svim drugim područjima života (osim radnog mjesta) kao što je to primjerice slučaj među djecom te posebno braćom i sestrama i samim prijateljima.

Prikazi u koje smo se u oslanjanju na B. Weltea upustili sugeriraju da sukob i rivalstvo proizlaze iz prirode ljudskog suživota. Tome u prilog ide i činjenica da nacionalni epovi s kojima su se narodi barem donedavno poistovjećivali i u kojima su pronašli svoj identitet uvijek govore o herojima, odnosno o pobjednicima u bitci. Tu pripadaju biblijske priče o pobjedi Izraela nad narodima Kanaana, herojska priča o Davidu i Golijatu, u njemačkoj legendi o junaku Sigfridu Zmajoubojici na burgundskom dvoru, usmrćenju Sigfrida te o tome kako se njegova supruga Kriemhilda osvetila - primjeri koje dakle i sam Welte navodi. ${ }^{221}$

\subsubsection{Regulacije $i$ pravila $u$ natjecateljskim igrama - dopuštanje doziranog $i$ plodonosnog sukoba u igri}

Svaka borbena igra dakle podliježe pravilima koji u arhetipskom smislu ukazuju na poštovanje rituala. Važnost rituala i pravila igre jest upravo u tome da su šanse za pobjedu obje sukobljene strane približno jednake. Tako u natjecateljskoj igri do izražaja dolazi odmjeravanje snage, upornost i prethodna priprema pojedinih timova te uloga i doprinos njihovih pojedinačnih članova. Svaka natjecateljska igra podliježe i određenim sankcijama ako se ne poštuju unaprijed određena pravila igre. ${ }^{222} \mathrm{O}$ tome odlučuje sudac kao pojedinac koji bi trebao pravedno suditi. Obje su sukobljene strane toga svjesne i to bi trebale poštovati. $\mathrm{S}$ jedne strane ovo reguliranje borbene igre daje sukobljenim stranama smislen oblik igre te $\mathrm{u}$ formalnom smislu omogućuje provođenje, to jest sam tijek igre. I upravo ta regulacija daje smislen oblik rješavanja sukoba od onog koji bi bio besmislen i protivan svakom pravilu. U suprotnom bi zasigurno borbene (natjecateljske) igre izgubile svoj smisao kada, naime, ne bi postojala nikakva granica do koje su dopuštene borbe i rivalstvo. U žaru borbe, reći će Welte, često se događa to da pojedinci uvijek iznova prelaze granicu dopuštenog, zato upravo postoje kazne i sankcije koje sprječavaju da se to ponovno dogodi. ${ }^{223}$ U svakom slučaju borba uvijek ima svoju granicu do koje može i smije ići kako bi se igra mogla nazvati smislenom. Borba je dopuštena, ali suparnici moraju biti korektni jedni prema drugima. Oni protiv kojih se bore samo su njihovi protivnici, ali ne i neprijatelji. Prema Welteovu mišljenju, postoji kvalitativna

\footnotetext{
${ }^{221}$ Usp. WELTE B. Isto, str. 258.

${ }^{222}$ Usp. Isto, str. 259.

${ }^{223}$ Usp. Isto, str. 269.
} 
razlika između borbe protivnika i borbe neprijateljstva. ${ }^{224} \mathrm{U}$ oba slučaja dolazi do borbe, ali je posve različito protivništvo od neprijateljstva. U prvom slučaju uvijek dolazi do poštenog rješavanja sukoba protivnika koji nisu neprijatelji. A u drugom slučaju, kojeg se treba čuvati, može doći do kobnih situacija. Oba područja, koja su kvalitativno različita, povezana su impulsom za borbu koji, ako se ne ukroti, prelazi kvalitativnu granicu. ${ }^{225}$

Gdje god ljudi žive zajedno i komuniciraju jedni s drugima, pojavljuju se pravne norme koje, poput pravila igre ${ }^{226}$, zahtijevaju priznanje svih uključenih strana i čija je svrha regulacija suživota na dobro svake od strana. Uvijek postoji granica, to jest zakonska regulativa koja sprječava da igra prijeđe u potpuno neprijateljstvo, isključivanje druge strane i da se tako povrijedi kvaliteta igre koja je jedino bitna. Ta regulativa omogućuje da igra bude i ostane samo igra u kojoj će se ljudi i zabaviti te uz napor eventualno opustiti, ponekad i rastužiti, ali uvijek imajući na umu da je sve to samo igra. Welte je mišljenja kako je dobro regulirana igra rivalstva ugodan i poželjan oblik životne igre, a natjecateljske utakmice to upravo dokazuju. ${ }^{227}$

Ipak, prema Welteu, najveći problem borbenih igara jest taj što često očituje neobuzdani instinkt za postizanjem moći te se sukob vrlo brzo ponovno rasplamsava. Zato nogomet kao primjer igre u kojoj postoje sukobljene strane pokazuje kako bi se igra trebala odvijati - i uz temperamente pojedinaca koji igraju i sve napetosti igre ona mora ostati samo igra uz nužno očuvanje mira među protivnicima. Poglavito u svijetu borbenih igara te napose u nogometu, košarci i rukometu izraz „fair play“ označava poštenu igru, a već je postao i dio filozofije poštivanja drugih i poštivanja pravila koje određena igra propisuje, kako na sportskim terenima, tako i u poslu i drugim društvenim sferama u kojima osoba živi u suživotu s drugim ljudima. ${ }^{228}$ Izraz „fair play“ zapravo je dio sportskog načina života i mnogi su ga doživljavali kao novi oblik praktičnog morala i sportskog etosa. ${ }^{229}$ Igra, naravno, nikad ne bi smjela biti dosadna, nego živa i svakako dinamična, no ipak u svoj svojoj živosti i smjelosti uvijek treba ostati samo to - igra koja će završiti na miroljubiv način između sukobljenih strana. Welte ovaj način iščekivanja završetka igre povezuje s onim što je u Bibliji obećano kao Božje kraljevstvo koje će doći. Prema njemu ova nada i njezino iščekivanje djeluju u povijesnom procesu kao stalni zadatak i obveza. Oblici ostvarenja nade

\footnotetext{
${ }^{224}$ Usp. Isto.

${ }^{225}$ Usp. Isto, str. 260.

${ }^{226}$ Često znamo na početku nekog ozbiljnog posla reći „pravila su igre ova“.

${ }^{227}$ Usp. Isto, str. 260-261.

${ }^{228}$ Usp. RENSON R., Fair play: porijeklo pojma i njegovo značenje u sportu i društvu, u: Kinesiology, 41 (2009) 1, str. 5-18.

${ }^{229}$ Usp. Isto, str. 5-18.
} 
uvijek se i iznova stvaraju i pretvaraju u stvarnost kao mogućnosti mirnog života, a u konačnici mirnog sukoba i mirne borbe koja svoj kraj doživljava tek u vječnosti koja je obećana svakoj osobi kao pojedincu koji živi u suživotu s drugim ljudima i doživljava svoj konačni smisao.

U povijesnom suživotu ljudi uočava se kako pravni poredak regulira suživot među osobama. No više se puta dogodilo i to da se revolucionarnim procesima pokušalo srušiti postojeći poredak koji je bio označen kao nepravedan. Kao rezultat toga proglašava se novi zakon i javlja se zahtjev za suverenitetom. Welte daje primjer modernih država koje tvore suverene društvene skupine, a čije se postojanje odvija također na način poštivanja pravila igre. Unutar pojedinih država, kao i kod država međusobno, postoji konstantno rivalstvo ekonomsko, političko itd. Njihovo međusobno postojanje, odnosno suodnos, odvija se upravo na razini svojevrsne igre pri čemu na poseban način, kako naš autor kaže, treba biti na oprezu jer sukob između dvije sukobljene državne zajednice može prerasti u neobuzdano neprijateljstvo koje završava tragično. ${ }^{230}$ Welte je mišljenja kako baš zato u toj opasnoj igri sila i suprotnosti uvijek treba tražiti pravilo koje bi vrijedilo kao formativni ideal koji bi omogućio ograničavanje neobuzdanog neprijateljstva i njegovo ograničavanje. Čak se i u predizbornim kampanjama traži poštivanje pravila uzajamne pravičnosti. Kroz čitavu su povijest (te posebno u židovstvu i kršćanstvu) ljudi tražili mir u Bogu i mir na zemlji, odnosno izbjegavanje nasilja koje je konstantno pratilo ljudski rod. Za to su izbjegavanje ili, bolje rečeno, kanalizaciju nasilja ljudi, odnosno politički poretci iznalazili razna rješenja i mogućnosti. Prepoznatljivo je upravo to da je rivalstvo, štoviše, neprijateljstvo redovito bilo zamjenjivano igrom, jasno na simboličan način. Jedan su od primjera u srednjem vijeku i događaji poput karnevala (poklada) gdje su se nastojali upravo na načelu „totalne“ igre riješiti (simbolički svakako) problemi kojim je bila izložena zajednica, kao i odnosi među kneževstvima. Dopušteno se ismijavala i šali podvrgavala ona druga strana, pa bio to i sam kralj, bez opasnosti da će ista ,igra“, odnosno poigravanje s drugom stranom skrenuti u sukob i nasilje. U tom smislu organizacija velikih sportskih događanja na međunarodnoj razini (olimpijske igre, europsko i svjetsko nogometno prvenstvo, atletska liga itd.) očituje upravo, među ostalim, i tu dimenziju: dopuštanje doziranog natjecanja koje u krajnjoj osnovi ima povezivanje i zajedništvo među ljudima (narodima).

Sukobi su dakle neizbježni među ljudima, kao i u međunarodnim odnosnima. Kod igre smo primijetili da ju ljudi premještaju, namjerno i nenamjerno, na svakodnevni život pri čemu

\footnotetext{
${ }^{230}$ Usp. WELTE B. Isto, str. 261.
} 
sama igra, koliko god se odvijala u svojevrsnoj slobodi i neopterećenosti, u sebi mora sadržavati pravila. Štoviše, ta pravila i norme omogućuju „dirigiranu“ borbu i natjecanje te štiti da oni ne prijeđu u nekontrolirano sukobljavanje na terenu. Kako smo naveli, međunarodni su odnosi svakako ozbiljniji te potrebuju strožu regulaciju, odnosno „pravila igre“ da ne bi skliznuli u konflikte čije su posljedice mnogo opasnije. Ženevska je konvencija ${ }^{231}$ Crvenog križa primjerice pokušaj umjerenog djelovanja na suverenoj međunarodnoj razini s obzirom na konflikte i sukobe koji se javljaju u svijetu koji se pak, za razliku od arhaičnih društava, ne mogu (potpuno) kanalizirati igrom. Deklaracija UN-a o ljudskim pravima, koja su ugrađena u ustave gotovo svih modernih država, također pripada ovom redu. ${ }^{232}$ I na najvišoj su razini, primjerice razgovori između nuklearnih sila, SAD-a i ondašnjeg SSSR-a, znak da ljudi neprestano traže zlatno pravilo koje ubojito neprijateljstvo pripitomljava na humanu igru poštenih protivnika. ${ }^{233}$ Čini se, reći će Welte, kako je karakteristično da čovječanstvo uvijek iznova pokušava pronaći i razviti dragocjena pravila igre iz impulsa koji se dizao iz dubina ljudskog bića, tajanstvenog rituala koji je omogućio opasne igre ljudskih sukoba, kako bi se podigla humana kvaliteta odnosa te života uopće. ${ }^{234}$ Welte je mišljenja kako su sve ove konvencije i deklaracije uspješne $u$ tom smislu da rasprave, kao i ono što nazivamo ,zdravi konflikti“, poput neslaganja u vidu rasprava i dijalogiziranja između „sukobljenih“ strana da budu održive, ali bez da skliznu u otvoreno nasilje i latentno sukobljavanje, pri čemu se upravo zbog toga zadržava potrebni mir.

Dubina Welteovih antropološko-socijalnih uvida i njihova filozofsko-teološka perspektiva ovdje se uistinu pokazuje značajnom. Naš se filozof religije, naime, ovdje pokazuje kao staloženi realist ne očekujući od svijeta i društva nemogući ideal, to jest savršen mir, lišen bilo kakvih sukobljavanja. Za primijetiti je da je Welte ovdje, svjesno ili nesvjesno, pod utjecajem sv. Augustina i njegova razlikovanja nebeske i zemaljske države, pri čemu ta razlika svakako ostaje trajna, međutim, s ukazom na to da se zemaljska trajno mora ugledati na nebesku, to jest težiti prema miru te dalje pravednosti, dobru i vrijednostima uopće. U tome je smislu Welteu jasno da se u zemaljskoj državi mir nikad ne može potpuno, već samo

\footnotetext{
231 Ženevske konvencije - skupni naziv za niz međunarodnih ugovorâ sklopljenih radi zaštite osoba koje ne sudjeluju ili više ne sudjeluju u ratnim operacijama. Prva Ženevska konvencija od 1864., nastala kao rezultat zauzimanja Švicarca H. Dunanta za humanizaciju ratnog prava, odnosila se na ublaživanje patnji ranjenika u ratu bez obzira na njihovu pripadnost. Ženevske konvencije, u: Hrvatska enciklopedija, mrežno izdanje. Pristupljeno 12. 10. 2020. Dostupno na: https://www.enciklopedija.hr/natuknica.aspx?ID=67690.

${ }^{232}$ Usp. WELTE B., Gesammelte Schriften Person I/I, str. 261.

${ }^{233}$ Usp. Isto, str. 261.

${ }^{234}$ Usp. Isto.
} 
djelomično zadobiti, stoga on drži vrijednim i važnim spomenute deklaracije kojima je upravo temeljni cilj suživot među ljudima.

\subsubsection{Borbena igra kao simbol života uopće: primjer nogomet}

Borbene igre Welte dakle promatra kao simboliku života. U svojim filozofskim razmišljanjima o nogometnoj igri kao igri koju je posebno izdvojiti od svih borbenih, to jest natjecateljskih igara, on smatra kako ona zahtijeva dublje objašnjenje svoje svjetske distribucije i ogromnog broja zainteresiranih. Nogomet je igra koju vole mase diljem planeta i mnogi narodi. Welte spominje jednu zanimljivost vezanu uz svjetsko nogometno prvenstvo koje se održalo 1978. godine u Argentini na kojem su prisustvovali aktivni igrači iz 135 zemalja svijeta, a koje su gledatelji pratili putem svojih TV-ekrana; svjetsko prvenstvo koje se održalo 1970. godine imalo je više od 700 milijuna TV-gledatelja. ${ }^{235}$ Welteu je bilo vrlo zanimljivo promatrati silni interes mnogih pojedinaca za ovu igru. Ono što naš filozof religije zamjećuje jest kako je taj interes mnogo veći čak i od onog za velike i važne političke vijesti. Vrlo znakovito za Weltea je bilo to da su sve dnevne novine bile prepune nogometnih vijesti uoči svjetskog prvenstva, iako je bilo dovoljno političkih tema da popune svaku stranicu. Naš filozof iz Freiburga primjećuje kako se nogomet kao vodeći sport na ovoj razini natječe s glavnim svjetskim povijesnim događajima. Stotine milijuna ljudi posebno su intenzivno zainteresirane za ovu igru. Nogomet se, kako spomenusmo, kao borbena igra po sebi igra s ozbiljnošću, čak i sa strašću i uz upotrebu svih sila i vještina koje posjeduju natjecatelji. ${ }^{236}$ Prema Welteu, to je paradigma prave borbe, iako se odvija kroz igru. Upravo se na primjeru nogometa može vidjeti kako može biti fatalan izostanak borbenosti i natjecanja. Naime, ne radi se samo o tome da će izostati strasti i dinamike potrebnih za igru, već je to znak da je nogometna igra skrenula u himbu kojoj je u osnovi korupcija: dosta je, naime, primjera iz ove igre gdje jedna strana ,pušta“ drugoj rezultat tako da pravi odmak od borbenosti, upravo zbog navedenih nečasnih ciljeva. Izostankom borbenosti igra gubi svoju posebnost. Takva borba sa sukobima koji se odvijaju unutar nje naziva se borbom rivalstva. Borba rivalstva zapravo znači kako su ljudi na bojnim poljima suparništva s vlastitom vrstom i u svim sukobima koji joj pripadaju. ${ }^{237}$ Osobe koje sudjeluju u ovoj igri i sličnim igrama uvijek imaju protivnike s druge strane. Uzbudljivi dio igre jest upravo u tome da promotrimo tko izlazi kao pobjednik i

\footnotetext{
${ }^{235}$ Usp. Isto, str. 265.

${ }^{236}$ Usp. Isto, str. 265.

${ }^{237}$ Usp. Isto, str. 267.
} 
kome je pripala slava nakon pobjede. Oduvijek se narodi identificiraju s pobjednicima u borbenim igrama. Slično to rade i simpatizeri nogometnih utakmica gdje se kroz navijanje poistovjećuju s pobjednikom kako u svakoj pojedinoj utakmici, tako i posebno na europskom ili svjetskom prvenstvu. ${ }^{238} \mathrm{U}$ borbenim igrama, poglavito nogometu, uvijek biva prisutan borbeni impuls i borbeni ritual. Ritual zastupa i provodi sudac kojeg prepoznaju i poštuju obje „sukobljene“ strane. On zapravo nadzire i provodi igru. Budući da ga takvim prepoznaju i prihvaćaju obje natjecateljske strane, protiv njega se ne bore, kao što se ni on ne bori protiv onih kojima sudi. Ovaj ritual reguliranja daje cijeloj nogometnoj igri smislen oblik te ju uopće i omogućuje.

Prisutnost sudca u igri omogućuje u bitnome rješavanje sukoba kako igra ne bi postala besmislena. Impuls koji borbena igra ima često može voditi u sankcije i kazne jer natjecatelji zaborave na granice do kojih je sukob dopušten. Nogometna je igra, kao i igra uopće, zapravo izraz načela nade koja kao kršćansko načelo, eshatološki orijentirano, još uvijek vrijedi u smislu iščekivanja života kojem se nada. ${ }^{239}$ To je iščekivanje onog što se u Bibliji naziva Božjim kraljevstvom. Welte je mišljenja kako ovako promatrana nada i njezino iščekivanje djeluju u povijesnom procesu kao stalni zadatak i obveza. Uvijek postoje oblici ostvarenja nade koje treba osmisliti i provesti u ovoj stvarnosti, kao što su primjerice mogućnost mirnog života i mirnog sukoba, čak i mirne borbe. Nada prekoračuje granice povijesti, njezino iščekivanje zahtijeva stvarno oblikovanje povijesti, uključuje sve ljude, ali u konačnici ukazuje na nešto što je izvan povijesti - misterij koji je veći od svega ljudskog. Čini se da je to teološka strana onih ljudskih odnosa koje smo pokušali pročitati iz igre, shvaćene kao mitski arhetip. Kao izraz ove nade, čak i nešto posve borbeno poput nogometne utakmice, može upravo po tome imati svoju skrivenu teološku stranu.

\section{3. Čista igra}

Posljednja, ali ne manje važna igra u Welteovu promišljanju o osobi i ljudskom postojanju jest tzv. čista igra. ${ }^{240}$ To je jedna od najdubljih i najtajanstvenija od svih igara. Welte ovdje pravi radikalni zaokret u razmatranju igre navodeći da se ovdje radi o čistoj igri poezije. Ona se pojavljuje u raznim oblicima kao jezična poezija, kao likovna umjetnost i u

\footnotetext{
${ }^{238}$ Usp. Isto, str. 268.

${ }^{239}$ Usp. Isto, str. 268.

${ }^{240}$ Usp. Isto, str. 263.
} 
konačnici kao glazba. Posebice glazbu Welte označava i uzima kao model čiste igre. ${ }^{241}$ I glazba predstavlja jedan vid igre koja proizlazi iz onog što nazivamo ozbiljnošću života i tako razvija novi poredak u odnosu na tako shvaćen ozbiljan život. Taj novi poredak jest jedan idealni poredak koje predstavlja savršenstvo koje se jasno ističe od svih uobičajenih aktivnosti ljudi. Idealni poredak u glazbi ne predstavlja neku igru na sreću, iako i glazba kao čista igra mora biti uspješna, to jest izvedena prema točnim pravilima, odnosno idealu koji je unaprijed postavljen. Glazba je prema Welteu poseban vid čiste igre gdje nema borbe iako i u njoj ima argumenata za rivalstvo. No u glazbi kao čistoj igri nijedno od spomenutih stvarnosti nije presudno. Glazba, prema Welteu, proizlazi iz čistog podrijetla i zrači nekim posebnim svojim sjajem. ${ }^{242}$ Cijeli svijet ima ovu karakteristiku i blista u svjetlu tog čistog podrijetla. Sve što čini i karakterizira ljudski život na ovom svijetu izlazi kroz glazbu na vidjelo. To može biti radost i bol, svjetlost i mrak, život i smrt, glasovi koji se međusobno prepiru, pomiruju, mladenačka sreća, kao i duboka melankolija - sve su to stvarnosti prisutne u ljudskom životu i postojanju. Kroz glazbu osoba biva oslobođena težine onog što se naziva stvarnošću, tako smatra naš filozof religije. ${ }^{243}$ No glazba, kao i sve vrste jezične poezije, ima svoja pravila igre. Svaka (izvrsna) glazba ima, naime, svoje norme, okvire, svojevrsne obrasce što ju pak u njezinoj ukupnosti čini ozbiljnom. Onaj tko živi glazbu, može osjetiti njezinu najveću ozbiljnost i točnost njezinih događaja. U ovoj čistoj igri nema nereda ili samovolje. Njezino je pravilo posebne vrste. I u glazbi dolazi do poraza i pomirenja u isto vrijeme. To je cjelina onog što nazivamo životom u tajanstvenom, preobraženom obliku. U simbolu glazbene poezije to je način na koji se vječna tajna bavi privremenim oblicima svijeta i čovjeka. ${ }^{244}$ To je ono što je Hegel nazvao „bakantski zanos“ - što je metafora za ono istinito. ${ }^{245} \mathrm{U}$ tom smislu Hegel piše u svojoj Fenomenologiji duha sljedeće: „Tako je ono istinito bakanatski zanos, u kojem nema člana koji ne bi bio opijen; a kako se svaki član, tim što se izdvaja, isto tako neposredno razrješava, taj je zanos također providno i jednostavno mirovanje. “246 I više je nego očito da se u tumačenju bakanatskog zanosa u Hegela radi o tome da je nositelj ovog zanosa Bakho (Bákhos) - zapravo starogrčki bog Dioniz (Diónysos) jer je ovo grčko

\footnotetext{
${ }^{241}$ Usp. Isto.

242 Usp. Isto.

${ }^{243}$ Usp. Isto.

${ }^{244}$ Usp. Isto, str. 264.

${ }^{245}$ Usp. BORŠ V., Istinito kao bakanatski zanos: uloga i važnost pluriperspektivizma u Hegelovoj misli, u: FI, 36 (2016) 4, str. 775-785. Hegel u svojem djelu Phänomenologie des Geistes iz 1980. piše sljedeće o bakanatskom zanosu: »Das Wahre is so der bacchanatische Taumel, an dem kein Glied nicht trunken ist; und weil jedes, indem es sich absondert, ebenso unmittelbar (sich) auflöst, ist er ebenso die durchsichtige und einfache Ruhe."

${ }^{246}$ HEGEL G. W. F, Fenomenologija duha, prev. Kangrga M., Naprijed, Zagreb, 1987., str. 32.
} 
božanstvo u mitologiji imalo razna nazivlja i imena, poglavito s obzirom na stari Rim koji obilato preuzima i koristi upravo grčku mitologiju u raznim područjima svojeg kulturnog života. ${ }^{247} \mathrm{U}$ tom je smislu te zbog različitosti Hegelov "Bakho« upravo onaj Diónysos iz grčke mitologije jer Hegel za svoju alegoriju o istini kao temelju koristi Euripidovu dramu Bakhe.

Vrijednost bakanatskog zanosa i sam spomen u Welteovu promišljanju o ljudskom postojanju i različitim oblicima kroz koje se to postojanje manifestira jest upravo u tome da je Bakho zapravo simbol vječnog života, rasta, neprestanog obnavljanja, produhovljenja, ali i razaranja u svrhu oslobođenja te integriranja suprotnosti. ${ }^{248}$ Zbog toga Welte spominje Hegela i bakanatski zanos kao stvarnost pripadnu glazbi koja je uvijek vječna i vodi k nečem većem od dosega konačnog čovjeka. „Bakhu“ u čast održavale su se različite svečanosti koje su bile obilježene zanosom koji Welte pripisuje glazbi kao najčišćoj vrsti igre u sklopu ljudskog postojanja. ${ }^{249}$ Welteovim riječima, glazba je uvijek predstavljala zanos i unutar nje je prisutan uvijek svečani trenutak, ona sama jest neka vrsta svečanosti prožete igrom. Zanos koji se u okviru svojevrsnog reda usustavljuje (igra s pravilima) pokazuje što je Welte pomišljao pod pojmom čistoće, odnosno time da glazba ima svečan, čist karakter. Glazba je nešto neprolazno u životu pojedinca. Sve prolazno predstavlja određeni vremenski slijed koji je potpun tek kada više nije i kada zadnja nota izblijedi. Ona je uvijek više od igara na sreću ili borbenih igara. Glazba shvaćena na ovaj način jest i obećanje. Welte ističe za glazbu da ona i bez riječi govori svom slušatelju da se ne boji. Glazba je ona koja oplemenjuje svog slušatelja. Brlobuš o glazbi kaže sljedeće: „Onaj koji u sretnom trenutku shvati i prihvati da je zagonetno događanje glazbe zauvijek zaključano u neizrecivosti njezine tajne, taj odustaje od svakog mogućeg izrijeka o njoj - takav jednostavno glazbu sluša, pjeva, svira i najzad komponira. ${ }^{\text {e } 250} \mathrm{U}$ nečujnom bitku tišine događa se čujni bitak glazbe, i obratno: u čujnom bitku glazbe događa se nečujni bitak tišine. ${ }^{251}$ Tišina je stoga usko vezana uz glazbu, kao njoj usko pripadna karakteristika i vlastitost te svaka ozbiljna glazba i ima svoj vid tišine. To zapravo znači „raz-otkrivati ono „skriveno/neskriveno“ glazbe kao glazbe, drugim riječima znači stalno nagovarati na ono u glazbi neizgovorivo“. ${ }^{252}$

\footnotetext{
${ }^{247}$ Usp. BORŠ V., Istinito kao bakanatski zanos: uloga i važnost pluriperspektivizma u Hegelovoj misli, str. 780.

${ }^{248}$ Usp. Isto, str. 780.

${ }^{249}$ Usp. Isto, str. 780.

${ }^{250}$ BRLOBUŠ K., Tišinom ugođena zagonetnost glazbe, u: FI, 142 (2016) 2, str. 222.

${ }^{251}$ Isto, str. 222.

${ }^{252}$ Isto.
} 
Končano, glazba je za Weltea poseban primjer „čiste igre ${ }^{e e}$ upravo zato što njezina zagonetnost izmiče svim znanstveno-teoretskim promatranjima i ona se ne može spoznati znanstvenim putem, već osluškivanjem koje se kreće u obzorju nepojmljivog. ${ }^{253}$ Zato ju Welte smatra „,̌istom“e i prikladnim putem koji osobu može dovesti do savršenstva koje se događa u vječnosti. Welte zaključuje kako je glazba preteča savršenstva koje se događa u vječnosti.

\section{6. »Osvjetljavanje tubitka« u okviru Welteova promišljanja o osobi i njezinu postojanju}

\subsection{Uvod i pojam i problematika čovjekova postojanja}

Jedan od važnih pojmova koje Welte rado rabi jest takozvano osvjetljavanje tubitka ${ }^{254}$ u smislu osvjetljavanja postojanja kao takvog. U tom osvjetljavanju tubitka osoba postaje svjesna same sebe, postaje svjesna drugoga kojeg prepoznaje i oslovljava sa »ti«, svog svijeta i boravi u percepciji vlastita postojanja. Svijet u isto vrijeme jest sve ono oko mene što vidim, čujem, ali i sve ono što mislim te ono čega se prisjećam. Čak i ono potiho izgovoreno, kako to Welte kaže, ono za čim težim ili čega se bojim biva prepoznato kao nešto postojeće, ali sada zasjenjeno tim svjetlom čistine postojanja. ${ }^{255}$ Iz toga će razloga Welte reći kako je za to osvjetljavanje sposoban samo čovjek, osoba u kojoj egzistencija biva prisutna na posebniji način. Posebniji spram drugih bića koja ne egzistiraju na način na koji je to slučaj s ljudima.

Osoba se otvara tom postojanju na način koji je moguć jedino ljudskim bićima. Mogućnosti su postojanja različite, ali ono što se dade zamijetiti jest da neživa bića ne mogu čuti, misliti, vidjeti kao što je to slučaj sa čovjekom iako im čula mogu biti savršenija. Stoga takva bića ne mogu zamijetiti svoje postojanje. Ona su jednostavno sačinjena i konstituirana tako da pohranjuju informacije $u$ tehničkom smislu te ih zatim procesuiraju prema točno utvrđenim i unaprijed određenim obrascima koje otkriva čovjek.

Vanja Sutlić ističe kako je „tubitak“ središnji pojam Bitka $i$ vremena, a možda i Heideggerove filozofije uopće ${ }^{256}$, pa se ovdje samo unaprijed dotiče analize koja će doći

\footnotetext{
${ }^{253}$ Usp. Isto, str. 224.

${ }^{254}$ Najbliži prijevod Welteova »Die Lichtung des Daseins«, str. 26.

${ }^{255}$ Usp. WELTE B., Das Licht des Nichts. Von der Möglichkeit neuer religiöser Erfahrung, ur. Zaborowski H., Butzon\&Bercker, Kevelaer, 2015., str. 9-11.

${ }^{256} \mathrm{O}$ tome govori i SHEENAN T., Dasein, u: A Companion to Heidegger, ur. Dreyfus L. H. i Wrathall M. A., Blackwell Publishing Ltd, 2005., str. 193.
} 
kasnije i koja će tek pružiti pravi uvid. ${ }^{257}$ Sutlić je bio mišljenja kako dobro objasniti taj termin znači zapravo eksplicirati cijelu problematiku Bitka $i$ vremena. ${ }^{258}$ U njemačkom je izvorniku pojam »tubitak« označen izrazom „Dasein““259, a prevodimo ga kao postojanje ili opstanak. Kada se radi o Heideggeru, treba reći kako je za njega osobito važno bilo osloboditi se novovjekovnog pojma čovjeka kao subjekta, no nikako to ne znači da čovjeka treba promatrati kao objekt. U tom shvaćanju svega kao objekta nalazi se ontološka diferencija. U tom je smislu svejedno biva li subjekt u odnosu ili susretu s nekim cvijetom, kamenom ili čovjekom, pa i bogom jer sve je to objekt za njega iz gledišta subjekta. Stoga se i sam termin ontološke diferencije odnosi na razliku između pojedinačnih bića i bitka. Sve ono za što možemo reći da jest - to je neko biće. No sam bitak - koji daje da bude to nešto što jest biće ne predstavlja biće. Tim i takvim shvaćanjem filozofije Heidegger se zapravo suprotstavlja cjelokupnoj zapadnoj metafizici kojoj on upućuje prigovor zaborava bitka. Tradicionalna metafizika uvijek je tražila neko biće na koje može osloniti i utemeljiti sva ostala bića pa je tako za Aristotela to bio bio, kod Hegela apsolutni duh, Nietzsche i njegov nadčovjek te volja za moć itd. Heidegger svojim promišljanjem upravo to želi dovesti u pitanje. Na taj Heideggerov način dolazimo i susrećemo se s onim Ništa koje zapravo znači napuštanje svakog bića i mišljenja o njemu. Treba se osloboditi mišljenja ili, još bolje, volje za utemeljenjem nečega.

Welteova je nakana bila da pojmom tubitak i osvjetljavanje tubitka dade na važnosti ljudskom postojanju. Heidegger izrijekom ne govori kako se radi o čovjeku, nego nas navodi na taj zaključak. ${ }^{260}$ Heidegger izbjegavanjem uporabe riječi čovjek za tubitak zapravo izbjegava zapadanje u misao kako je to samo još jedno biće koje se pojavljuje i nalazi među drugim bićima. U tome i jest vrijednost Heideggerova „tubitka“ spram svih drugih postojećih bića jer to je ono biće koje smo mi sami: to biće koje sam ,ja sam“ nazivamo „tubitkom“. ${ }^{261}$

Uz pojam „osvjetljavanje tubitka“" susrećemo u Weltea i pojam „spona tubitka“ kojim označava upravo samosvjesnost osobe koja biva svjesna svoje vlastite egzistencije i postojanja. ${ }^{262}$ Govoreći o „osvjetljavanju“ kao i „sponi““ tubitka, važnim se nameće skrenuti

\footnotetext{
${ }^{257}$ Usp. SUTLIĆ V., Kako čitati Heideggera - Uvod u problematsku razinu Sein und Zeit-a i okolnih spisa, August Cesarec, Zagreb, 1984., str. 65.

${ }^{258}$ Usp. Isto, str. 79.

${ }^{259}$ Hedieggerovo razumijevanje prema većini interpretacija ne odnosi se na čovjeka jer Dasein je ontološka, a čovjek ontička sfera.

${ }^{260}$ Usp. HEIDEGGER M., Bitak $i$ vrijeme, posebice $\S 4$ gdje Heidegger, govoreći o tubitku, misli na čovjeka i njegovo postojanje.

${ }^{261}$ Usp. HEIDEGGER M., Prolegomena za povijest pojma vremena, ur. Mikulić B., Demetra, Zagreb, 2000., str. 167.

${ }^{262}$ Usp. WELTE B. Isto, str. 11-21.
} 
pozornost na sam pojam ,tubitka“. Kada govori o osobi kao nositelju fizičkih i duhovnih vrijednosti, Welte često rabi pojam „tubitak“. „Tubitak“ je pojam koji i naš filozof religije zasigurno baštini od M. Heideggera. Pojam tubitka proteže se kroz Heideggerovo krucijalno djelo Sein und Zeit u kojem Heidegger već na samom početku, u drugom paragrafu, pita o tome ,ako ne znamo što je to bitak, kako ćemo znati što je to pitanje“ ${ }^{\text {263 }}$ i upravo na tome mjestu započinje njegova filozofska misao. Zamjećujemo kako Heidegger nije želio započeti s apstraktnim pitanjima o tome što je to bitak, nego je pokušao određenim propitivanjem kako vrstom ponašanja doći do odgovora na to pitanje. Prilikom osvjetljavanja tubitka, ili osvjetljavanja postojanja, pojavljuje se ponašanje kao još jedan pojam koji je Welteu vrlo blizak i bitan za objašnjavanje ljudskog postojanja uopće i suživota između osobe ,,ja“ spram osobe „ti““. O nekim odrednicama ljudskog ponašanja već je bilo riječi u radu, a taj će se govor nastaviti u daljnjem promišljanju o osobi kod Weltea.

Otud se pokazalo da oblikovati pitanje o smislu bitka znači „raskriti samo to pitanje kao biće“, to jest raskriti sam „tubitak“, dakle ono biće koje smo mi sami, mi koji pitamo o tome. ${ }^{264}$ Heidegger je, zanimljivo, bio mišljenja da je, kako bi se došlo do toga odgovora - što zapravo bitak tubitka jest - potrebno preskočiti znanost. Potvrđuje to sljedećim izričajima: „Pritom moramo na neki način preskočiti znanost (i njene odgovore na pitanja o čovjeku), da bismo dospjeli do onog predznanstvenog i istinskog filozofskog otvaranja zbilje jer znanstveno istraživanje nije ni jedini ni najbliži mogući način bitka tog bića““ ${ }^{265}$ Slično Welte razmišlja kada isključuje samo puku znanost i znanstvena dostignuća u promišljanju o čovjeku koji je uvijek i duhovno biće (dakako, u filozofskom vidu, a zatim i drugim vidovima, poglavito religijsko-teološkom), stoga ga tako treba i promatrati. Pod tubitkom je mišljeno biće u svojem bitku: mi ga poznajemo kao ljudski život, ovo biće u svagdašnjosti svojeg bitka koje smo svi mi sami, koje svatko od nas označuje temeljnim iskazom: jesam. ${ }^{266}$ Iskaz ,jesam“ kod Weltea je zapravo potvrda postojanja koju osoba izgovara kroz prepoznavanje sebe same kao ,ja“ i drugog kao „ti“. U Weltea su osoba ,ja“ i osoba „ti“ one koje žive suživot u susretu i iz kojeg možemo dalje nastaviti govor o osobi.

\footnotetext{
${ }^{263}$ HEIDEGGER M., Bitak $i$ vrijeme, str. 1-4. i 343.

${ }^{264}$ HEIDEGGER M., Prolegomena za povijest pojma vremena, str. 167.

${ }^{265}$ Isto, str. 2.

${ }^{266}$ HEIDEGGER M., Kraj filozofije i zadaća mišljenja, str. 47.
} 


\subsection{Smislenost govora o ljudskoj osobi i tragovi transcendentnoga}

O pojmu osobe mnogo se govorilo tijekom cijele povijesti filozofije. Filozofska rasprava o ljudskoj osobi zasigurno je vrlo aktualna i živa i danas. Još od Aristotela ljudska osoba i ljudi općenito označeni su kao društvena bića koja su svakodnevno u mnogim interakcijama s drugim osobama. Osoba živi u zajedništvu s drugim ljudima. ${ }^{267}$ Mnoge znanosti, od društvenih i humanističkih, preko prirodnih i biomedicinskih do čak tehničkih (umjetna inteligencija), također progovaraju o čovjeku kao osobi i donose vlastite zaključke, no promatramo ih uzimajući u obzir i određena ograničenja kojima svaka od njih podliježe. Filozofski govor o osobi, kakav je Welte predstavljao, jest onaj koji ljudskoj osobi uvijek želi pristupiti kao cjelini. To pak znači da je to govor o načelima po kojima ljudska osoba jest upravo ljudska, a do kojih neke druge znanosti (pozitivne primjerice) ne mogu doći zbog same svoje naravi te to često završavaju i u ideološkim pravcima. Welte je istaknuo upravo važnost filozofskog govora o ljudskoj osobi koji je nužan kako bi se i u djelovanju zauzeo pravi stav prema svakoj pojedinoj osobi jer smo uvijek u relaciji spram drugoga, i živimo u zajednici. ${ }^{268}$ Relacionalnost osobe jest ključna dimenzija njezine ljudskosti iz čega proizlazi temeljna smislenost govora o njoj. Radi se o susretu između osobe ,ja“ i osobe „ti“ koje zajedno žive. Problem s naturalističkim shvaćanjem čovjeka i njegova podrijetla, prema Welteu, jest u tome što se usko shvaća čovjeka, tek kao životinju koja misli, a mišljenje je pritom samo rezultat evolucije. ${ }^{269}$ Stoga se nikako ne može pristati uz takvu poziciju jer čovjek nije samo evolucijsko biće, već ima i bitno duhovnu dimenziju, ne pretpostavljajući pri tome odmah njegovu religioznost, već spomenutu misaonost. A upravo ljudska misao nije dostupna našim osjetilima te ju se ne može verificirati na takav način kao što je to slučaj s osjetilnim datostima. Stoga bi svaki pokušaj opisivanja i definiranja čovjeka samo kroz prizmu jedne od spomenutih znanosti bio pogrešan i uvelike problematičan jer se mora uzeti u obzir sve što čovjek jest, to jest sve što u sebi takoreći sadrži.

U razmatranju čovjeka uz misao nužno ide i sloboda kojom se Welte nadalje bavi. Zanimljivo je to da do sukoba vrijednosti dolazi čak unutar liberalne filozofije zato što se sloboda izbora smatra najvišom vrijednošću, no treba imati uvijek na umu kako su ljudi ograničena bića, pa je samim time takva i njihova sloboda. Jer svatko djeluje prema svojoj naravi, pri čemu valja imati na umu da je ljudska narav u bitnome ograničena, podložna

\footnotetext{
${ }^{267}$ Usp. WELTE B., Gesammelte Schriften I/1 Person, str. 14.

${ }^{268}$ Usp. DADIĆ B., KNEŽIĆ I., Metafizička istraživanja o osobi, u: Riječki teološki časopis, 17 (2009) 2, str. 545.

${ }^{269}$ Usp. Isto, str. 545.
} 
mnogim utjecajima. U tom smislu ni sloboda ne može biti označena kao najviša vrijednost. ${ }^{270}$ U suprotnom bi i osoba bila samo sredstvo za postizanje nekog cilja, u ovom slučaju za postizanje te najviše vrijednosti koja je, prema zagovornicima radikalnog vida slobode, upravo sama sloboda. Welte će reći kako treba izbjegavati priklanjanje bilo kojoj od ideologija koje bi povrijedile vrijednost i dostojanstvo te u konačnici smislenost govora o ljudskoj osobi. Svakako na tom putu treba razlikovati pojam osobe od pojma individue.

Već je Aristotel razmatrao načelo individualizacije, stoga treba započeti od tog načela prilikom razlikovanja ovih pojmova. ${ }^{271} \mathrm{Za}$ načelo individualizacije Aristotel kaže kako je to upravo ono načelo kojim se jedan čovjek unutar ljudske vrste razlikuje od drugog čovjeka. ${ }^{272}$ Kada kažemo individua ili biti individua, to znači zapravo obilježje nekog bića koje čovjek dijeli s drugim bićima unutar te prirode. ${ }^{273}$ Jacques Maritain razmatra također načela individualizacije, napominjući pri tome uobičajeno kako je svaki čovjek (samo) jedinka unutar ljudske vrste i dio cjelokupne materijalne stvarnosti te sasvim očigledno podložan fizičkim i kozmičkim zakonitostima. ${ }^{274}$ N. A. Berdjajev kaže za individuum kako je on sociološka, naturalistička i biološka kategorija koja se neprekidno promišlja unutar cjeline te se izvan te cjeline ne može označiti individuumom. ${ }^{275}$ Čovjek nikako nije samo materijalna individua jer osim onog materijalnog u njemu postoji i duhovno načelo. To Welte ne propušta spomenuti kada razmatra o osobi kao individui. ${ }^{276}$ Duhovno načelo individua, međutim, Welte ne želi pojednostavljeno tumačiti u perspektivi „božanske“ kategorije, već čovjekove umnosti i odnosnosti. Osoba jest individua, samostojna i odvojena od drugih, te nepriopćiva moj ja ne može postojati u drugima, kao što tuđi ja ne može postojat u meni, međutim, osobu, prema freiburškom filozofu, valja uvijek razumijevati kao onu koja je u bitnome upućena na druge osobe te s njima živi u zajednici. Radikalni prekid svih odnosa, relacija s drugima, u konačnici znači smrt, nepostojanje. Stoga osoba po svojoj unutarnjoj strukturi ne može živjeti odvojeno (od suživota) s drugima. Tako osoba za druge uzima sebi slične, međutim i različite. Odnosnost o kojoj ovdje govorimo u kontekstu Welteova razumijevanja osobe svoje utemeljenje ima, prema njemu, u specifično duhovnom načelu. Ono ga usmjeruje na bitak kao unutarnje načelo bića. Vidljivo je da je on ovdje na tragu cjelokupne, klasične filozofske misli

\footnotetext{
${ }^{270}$ Usp. WELTE B., Gesammelte Schriften I/1 Person, str. 69-74.

${ }^{271}$ Usp. KALUĐEROVIĆ Ž., Stagiraninova aitiologija, u: Znakovi vremena, 16 (2013) 59, str. 80.

${ }^{272}$ Usp. ARISTOTEL, Metafizika, prev. Gavela B., Kultura, Beograd, 1971., str. 177.

${ }^{273}$ Usp. DADIĆ B., KNEŽIĆ I., isto, str. 548.

${ }^{274}$ Usp. MARITAIN J., Tri reformatora, prev. Kovačević M., Laus, Split, 1995., str. 23.

275 Usp. N. A. BERDJAJEV, O čovekovu ropstvu i slobodi, prev. Jovanović Lj., Književna zajednica Novog Sada, Novi Sad, 1991., str. 49.

${ }^{276}$ Usp. WELTE B., Gesammelte Schriften I/1 Person, str. 172.
} 
kako grčke, tako i kršćanske, odnosno teološke, koja na dušu gleda kao na nematerijalnu supstanciju (primjerice kod Tome Akvinskog). Iz toga dalje proizlazi i dostojanstvo osobe. Iz ovog specifično ne-materijalnog tumačenja Welte promatra i slobodu koja osobi (neotuđivo) pripada po naravi i ne može svesti na samo jedan aspekt njezina postojanja. Osobnost preciznije gledana jest ukupnost stečenih i naslijeđenih kvaliteta i nedostataka te pripada, istina, u akcidentalni, ali nimalo zanemariv red bivstvovanja. ${ }^{277}$ Osobnost se kod čovjeka formira svjesnim i slobodnim činima, međutim, svakako je i kontekstualno određena društveno nasljeđe poput obitelji, zajednice itd.

Osobno se u Weltea uvijek odnosi na osobnu crtu ponašanja, na ljudske postupke i, prije svega, ljudske jezične čine u kojima se pojavljuje crta osobnosti. ${ }^{278}$ Ako nekog oslovljavamo sa „ti“, onda se (već) krećemo u području osobnog. A osobe su jedina bića koja možemo oslovljavati sa „ti““. To oslovljavanje sa „ti“, reći će Welte, jest jednostavno i elementarno događanje; ono ništa ne pretpostavlja i započinje sámo sobom. ${ }^{279}$ Oslovljavanje s „ti““ oslovljava oslovljenog kao njega samog. Ono se odnosi na sebstvo oslovljenog i na svoj način izvršava sebstvo: „ti sam““ ${ }^{280}$ U Weltea sebstvo treba shvatiti kao odnosno. Ono se, naime, odnosi na sebe samo, izvršava samo sebe samim time što postoji za sebe i u sebi te je samom sebi razvidno te samo sebe izvršava i samo se iz sebe pokreće. ${ }^{281}$ To pak dalje znači da ljude možemo i trebamo oslovljavati sa „ti“, dakle kao bića koja su samima sebi jasna i sebe izvršavaju te mogu odgovoriti na naš poziv. Treba reći kako jedino ljude možemo oslovljavati ovako jer mi je drugi čovjek ravnopravan partner u komunikaciji i zajedništvu. Samo pozivanjem druge osobe, slične meni, mogu računati s mogućnošću odgovora. U tome i jest bogatstvo odnosa ,ja“ spram „,ti“.

Osobe, prema Welteu, nadalje posjeduju obzorje svijeta. To bi pak značilo kako osoba vlastitim izvršenjem razvija bitak cijelog svijeta. Osobe su dakle same sebi pripadajući iskoni, one potpadaju pod sklop odnosa iskona s iskonom te kao takve ostvaruju smisao i značajnost svijeta, a time i značajnost sveg bića u cjelini. ${ }^{282}$ Sve se zbiva u događanju u kojem, kako je spomenuto, jedan čovjek drugog oslovljava sa „ti“ i zato je osobnost ono najjednostavnije, a ujedno i najbogatije o čemu se može pričati i što uopće postoji. ${ }^{283}$ Osobnim odnosima pripada

${ }^{277}$ LUCAS R., Antropološki status, u: MRŠIĆ V. A., Status ljudskog embrija, Centar za bioetiku - FTI, Zagreb, 2001., str. 85.

${ }^{278}$ Usp. WELTE B., Filozofija religije, str. 112-113.

${ }^{279}$ Usp. Isto, str. 113.

${ }^{280}$ Usp. Isto, str. 113.

${ }^{281}$ Usp. Isto, str. 113.

${ }^{282}$ Usp. Isto, str. 117.

${ }^{283}$ Usp. Isto, str. 117. 
obzorje svijeta koje je neograničeno i upravo zato osobe mogu razgovarati o svemu što mogu zamisliti. U obzorju svijeta posebice na važnosti dobiva osobni i dijaloški život između osobe ,ja“ i osobe „ti“. Razgovor između tebe i mene, to od-mene-preko-prema-tebi i od-tebepreko-prema-meni, te ono između, reći će Welte, jest nešto, jest bitak bića. ${ }^{284}$ Upravo se u tom odnosu rasvjetljava bitak bića kao takvog. Pri tome treba razlikovati ono osobno konačnog bića i ono bezuvjetno biće, transcendirajuću osobnost, kako to Welte ističe, koja nadilazi sve konačno. Iz toga razloga to apsolutno i bezuvjetno nije personalno ni osobno i nema tu vrstu osobnosti kakvu ima konačno biće. Bezuvjetno naprosto samo po sebi djeluje kao ono koje i ono što djeluje. Na ovom se mjestu Welte poziva na Martina Bubera i naziva to bezuvjetno ,vječno ti““. ${ }^{285}$ To vječno ti uvijek ostaje nedokučivo i neizrecivo, ono ne potpada ni pod koji pojam. Welte ističe i Akvinčev stav kako Bog ne potpada pod kategorije (Deus non est in genere), što bi pak značilo kako Bog uvijek ostaje onkraj svakog mogućeg poimanja dostupnog konačnom biću, on je onkraj svake bićevnosti, izvor i iskon sveg osobnog života, stoga je ispunjen iskonskom osobnošću, ali tako da uvijek ostaje nedokučiva tajna. ${ }^{286}$ Svaka religija započinje s onim „ti“ molitve, a o pojmu i važnosti te vrstama molitve bit će više riječi u nastavku rada.

Za Weltea je osoba općenito spona materijalnog i duhovnog i kroz prizmu materijalnog čovjeka označavamo kao individuu, jedinku ljudske vrste koja je dio cjeline; kroz duhovnu dimenziju čovjek biva označen kao vrijednost, a nikako sredstvo za postizanje nekog cilja s pripadnim mu dostojanstvom. Stoga je čovjek taj koji je uvijek svrha svakog djelovanja, a nikad sredstvo za ostvarenje nekog cilja.

O problematici vezanoj uz ovu temu razmatrao je i J. Ratzinger kada spominje suvremeni relativizam koji, prema njemu, čovjeka dovodi na rub novog ropstva. ${ }^{287}$ Ratzinger naglašava, nasuprot sveprisutnom relativizmu koji vlada suvremenim svijetom $\mathrm{u}$ kojem subjektivnost i moć bivaju kao apsolutne vrijednosti, potrebu da se ponašanje i djelovanje pojedinca, kao i društva u cjelini, temelji na supstancijalnom dobru i istini. ${ }^{288}$ Ovaj svojevrsni apelativni diskurs koji je kod Ratzingera na djelu očituje ne samo specifično katoličko promatranje „,vrijednosti u sebi“ već očituje jedan klasični, svakako filozofski legitimni, realizam u etici: vrijednosti posjeduju ontološku gustoću bitka te se čovjek ne može ni iznaći niti osporiti, već jednostavno otkrivati. Ovoj dimenziji tzv. ontološke gustoće bitka

\footnotetext{
${ }^{284}$ Usp. Isto, str. 116.

285 Isto, str. 124.

${ }^{286}$ Usp. Isto, str. 124-125.

${ }^{287}$ Usp. RATZINGER J., O relativizmu $i$ vrjednotama, prev. Ivanda I., Verbum, Zagreb, 2009., str. 80.

${ }^{288}$ Usp. Isto.
} 
univerzalnih vrijednosti kao logička posljedica dolaze načela slobode i jednakopravnosti ljudi, odnosno ljudska prava općenito. Njihovim poštivanjem i priznavanjem (dobro, istina, pravednost itd.) ostvaruju se i ljudska prava. Na tom je tragu (kao vjernik) bio i Welte kada osobi priznaje posebnu vrstu dostojanstva i prava koja ju izdiže ponad svih drugih bića te koja ne ovisi o ljudskom iznašašću, pogotovo ne dogovoru i konvenciji. Prema svojoj je naravi osoba uvijek upućena na druge, na zajednicu u kojoj živi. U razmatranju o smislenosti ljudske osobe važno je istaknuti kako je čovjek upravo po svojoj duhovnoj dimenziji jedinstvena $\mathrm{i}$ neponovljiva osoba $\mathrm{s}$ vrijednošću koja nadilazi društvo i sva društvena ograničenja. $\mathrm{O}$ smislenosti ljudskog postojanja može se govoriti jedino polazeći od čovjekove otvorenosti spram drugog s kojim živi. Iz toga čovjek razaznaje i transcendentni smisao svog vlastitog bića što se dalje očituje kroz spomenute odnose $» j a \ll$ i osobe $» t i \ll$.

Kušar se ovdje slaže s Welteom kada kaže da ta relacija otvara perspektivu u kojoj spoznajemo totalitet čovjekova bivanja i konstitutivnu otvorenost tog totaliteta prema transcendentnom smislu. ${ }^{289} \mathrm{U}$ tome se smislu tragovi transcendentnog pokazuju kroz fenomene slobode, nade, ljubavi i čovjekove duboke nutarnje upućenosti na smisao. Posljednji smisao čovjekova postojanja jest u Bogu. Metoda koja vodi k čovjekovu dubljem razumijevanju tajne njegova vlastitog bića i upućuje čovjeka k vjeri u Boga, prema Kušaru, ima tri obilježja: prvo, ona je egzistencijalna jer polazi od življenog čovjekova iskustva opstojanja; drugo, ona je fenomenološka jer otkriva stvarnost egzistencije (fenomen) kako se ona sama od sebe pokazuje te eksplicira u njoj uključene pokazatelje i pitanja; treće, ona je i transcendentna ako ide za izlaganjem ontoloških pretpostavki potrebnih za razumijevanje iskustva koje se očituje u samom fenomenu egzistencije. ${ }^{290}$ Stoga u nastavku treba nešto reći o metafizičkoj konstituciji osobe te osobinama koje joj pripadaju samim time što ju označavamo kao osobu različitu od svih drugih živih bića koja ne možemo nazvati osobama.

\subsection{Metafizička konstitucija i temeljna svojstva osobe}

U govoru o osobi Welte zauzima stav kako je potrebno produbiti analizu govora o osobi objašnjenjem metafizičke konstitucije osobe. Polazeći od klasične definicije osobe, koja je aktualna još od Boetija i koja kaže da je „Osoba [je] individualna supstancija razumske

\footnotetext{
${ }^{289}$ KUŠAR S., Tragovi transcendentnoga (I. dio). Pitanje o smislu i problem transcendencije, u: Obnovljeni život, 49 (1994) 3-4, str. 305.

${ }^{290}$ KUŠAR S., isto, str. 306.
} 
naravi“, Welte nastavlja svoje daljnje promišljanje o osobi. ${ }^{291}$ Često se u svojim promišljanjima o osobi naš filozof religije nadovezuje na Tomu Akvinskog koji je zasigurno dao velik doprinos poimanju pojma osobe kakvo je i danas prihvatljivo. Prema Tomi Akvinskom, osoba je ono najsavršenije u cijeloj prirodi - subzistentni pojedinac razumske naravi. ${ }^{292}$ Supstancija je ontološki uvjet postojanja svih obilježja, funkcija i djelovanja čovjeka. Supstancija je ta koja omogućuje jedinstvo čovjekova identiteta u prostoru, kao i trajanje u vremenu. Bez obzira na sve promjene koje čovjek tijekom života prolazi, on uvijek ostaje i biva to što jest, čovjek. Ostaje isti čovjek, zadržava jedinstvo i kontinuitet bivstvovanja. ${ }^{293}$

Kada se radi o individualnosti osobe, tada treba reći kako je osoba konkretno, a ne univerzalno biće. Individualnost osobe znači da osoba kao samostalna cjelina unutar sebe posjeduje unutarnje jedinstvo i jedinstvenost po kojoj se razlikuje od drugih ljudi te neponovljivost. ${ }^{294} \mathrm{Na}$ svijetu ne postoje dva ista pojedinca koji bi bili potpuno iste osobe. Romano Guardini u svom promišljanju o individui kaže kako je to živo biće ako predstavlja zaokruženo jedinstvo konstitucije i djelovanja. ${ }^{295}$ U uskoj vezi s ovim pojmom jest i pojam naravi, a narav je kod Tome Akvinskog označena kao ona koja je nositeljica forme, prema tome forma, to jest osnova naravne stvari donositeljica je njezine naravi uopće. ${ }^{296}$ Kada se radi o pojmu individualne supstancije, mnoge stvari i događaji unutar postojećeg svijeta jesu supstancije, i to individualne, primjerice cvijet, kamen, biljka. Jesu dakle individualne supstancije, no to ih isto tako ne čini $\mathrm{i}$ osobom. ${ }^{297}$ Jedino osoba posjeduje razumsku komponentu, ratio, koji ju razlikuje od svih ostalih individualnih supstancija koje postoje i jesu. Racionalnost pak kao specifičnu odrednicu osobe posebno vezujemo za dvije ljudske moći: razum kao spoznajnu moć i volju kao moć težnje, točnije razumske težnje. ${ }^{298}$ Svrha cjelokupne čovjekove težnje, kao i ljudskog djelovanja, jest posjedovanje univerzalnog dobra u punini, odnosno posjedovanje bitka u punini. ${ }^{299}$ Bitak na koji je čovjek u svom mišljenju i djelovanju upravljen stvarnost je neovisna o našim mislima, to je subzistentni bitak, biće kojem je bit vlastiti bitak. Radi se o temelju sveukupne stvarnosti koji daje bivstvovanje

\footnotetext{
${ }^{291}$ Usp. WELTE B., Gesammelte Schriften I/1 Person, str. 96.

${ }^{292}$ Usp. Isto, str. 14 i 49.

${ }^{293}$ Usp. DADIĆ B., KNEŽIĆ I., Metafizička istraživanja o osobi, str. 555.

${ }^{294}$ Usp. WELTE B., Gesammelte Schriften I/1 Person, str. 172.

${ }^{295}$ Usp. GUARDINI R., Mondo e persona, Morcelliana, Brescia, 2000., str. 136.

${ }^{296}$ Usp. AKVINSKI T., Suma protiv pogana, sv. II., KS, Zagreb, 1993., str. 923-925.

${ }^{297}$ Usp. WELTE B., Gesammelte Schriften I/1 Person, str. 172.

${ }^{298}$ Usp. DADIĆ B., KNEŽIĆ I., Metafizička istraživanja o osobi, str. 556.

${ }^{299}$ Usp. KOZELJ I., Savjest, FTI, Zagreb, 1990., str. 199-203.
} 
svemu što jest. ${ }^{300}$ Osoba je stoga kako utemeljena, tako i usmjerena na bitak specifičnim moćima koje su joj usko pripadne - razumom i voljom te upravo iz toga proizlazi i vrijednost i dostojanstvo osobe kao takve. U čovjeku je dakle prisutan jedinstven spoj duše i tijela koji konstituira osobu. ${ }^{301}$

O pitanju jedinstva duše i tijela raspravljali su mnogi tijekom duge povijesti filozofije. Welte i na ovom mjestu rado spominje Tomu Akvinskog koji je govorio kako su duša i tijelo dva načela iz kojih nastaje jedno realno postojeće biće. ${ }^{302}$ Berdjajev je opisao to jedinstvo riječima: „duševni život prožima čitav život tijela, kao što i tjelesni život djeluje na život duše. Postoji vitalno jedinstvo duše i tijela u čovjeku“. ${ }^{303}$ Kada promatramo ljudsku osobu, uvijek moramo uzeti u obzir sve što osoba jest, po svom postojanju i bivstvovanju, a to je jedinstvo duše i tijela, s pripadnom slobodom i odgovornošću, nadalje razumom jer osoba misli, razumijeva i razmišlja, posjeduje »ratio« i razumsku komponentu te dostojanstvom koje joj pripada kao osobi koju pri tome i vrijednosno određujemo.

Gibajući se dalje u području filozofije, a s obzirom na konstituciju osobe, razlikujemo fenomenološko i vrijednosno određenje osobe. ${ }^{304} \mathrm{~S}$ obzirom na fenomenološko određenje osobe, uz istu se vežu vlastitosti koje ju označuju kao onu koja postoji i djeluje unutar svijeta u kojem živi. Te su vlastitosti neotuđivost, jedinstvenost, pojedinačnost, cjelovitost, relacionalnost i autonomija. One su bitne kako bi se stekla potpuna slika o osobi i što osoba jest. Prva od spomenutih neotuđivost odnosi se na ontološki identitet osobe koji je pripadan samo bivstvujućoj osobi i koji je neprenosiv na bilo koju drugu osobu. To zapravo znači biti osoba. R. Guardini je za neotuđivost istaknuo sljedeće: „ono biti sam svoj, u konačnici znači da ne mogu biti posjedovan od neke druge instancije, nego pripadam sebi““ ${ }^{305}$ Osoba i ono njezino 'biti' točno određena osoba ne podliježe nijednom posjedovanju od druge osobe jer sloboda i odlučivanje jesu usko vezane uz osobu i njezino bivstvovanje te se iz ove vlastitosti može iščitati vrijednost osobe koja je različita od svake druge osobe koja živi i postoji. Druga vlastitost karakteristična za osobu jest njezina jedinstvenost, a znači kako je svaki čovjek kao individuum nositelj ljudske naravi iako dijeli sličnosti s ostalim ljudima, ipak, svaki je čovjek ponaosob jedinstven u sebi. Dostojanstvo ljudskog bića (ne) temelji se dakle na tome što ono participira na zajedničkoj ljudskoj naravi, već na tome što je ono neponovljiva, jedinstvena

\footnotetext{
${ }^{300}$ Usp. Isto, str. 199-203.

${ }^{301}$ Usp. DADIĆ B., KNEŽIĆ I., Metafizička istraživanja o osobi, str. 559.

${ }^{302}$ Usp. AKVINSKI T., Suma protiv pogana, sv. I., KS, Zagreb, 1993., str. 655.

${ }^{303}$ Usp. N. A. BERDJAJEV, O čovekovu ropstvu i slobodi, prev. Ristić Lj., Književna zajednica Novog Sada, Novi Sad, 1991., str. 46-47.

${ }^{304}$ Usp. WELTE B., Gesammelte Schriften I/1 Person, str. 18-23.

${ }^{305}$ Usp. DADIĆ B., KNEŽIĆ I., Metafizička istraživanja o osobi, str. 560.
} 
ljudska osoba. ${ }^{306}$ Osoba je jedinstvo duše i tijela, materijalnog i duhovnog načela na temelju kojih nije moguće postojanje dvije potpuno iste osobe jer je svaka osoba originalna, neponovljiva i jedinstvena upravo po tom neponovljivom i originalnom načelu jedinstva duha i tijela. Dakle svaka osoba, ponovimo, posjeduje sebi vlastito dostojanstvo, vrijednost, originalnost i jedinstvenost. Kada se radi o vlastitosti koju nazivamo pojedinačnost, tada prvo treba spomenuti Berdjajeva koji je u svom djelu Ja i svijet objekata ustvrdio kako „osoba kao cjelovita ne pripada nijednom sistemu ili planu“ ${ }^{307}$ Priznanjem svakoj pojedinoj osobi njezina dostojanstva i vrijednosti koju priznajem i sebi kao osobi mogu ostvariti odnose s drugim ljudima, biti u zajedništvu i živjeti u zajednici.

Romano Guardini u djelu Osoba $i$ sloboda ističe tri karakteristike osobe: samopripadanje osobe, nezamjenjivost osobe i samojamstvo osobe. ${ }^{308}$ Iz ovih karakteristika osobe uviđa se upravo njezina posebnost i pojedinačnost koja je, iako osoba živi u zajednici, pripadna svakom pojedinom čovjeku i po kojoj osoba biva posebna u smislu neponovljivosti i nezamjenjivosti. Tu je i relacionalnost ili, kako smo mi označili, odnosnost. Mnogi su filozofi isticali upravo ovu vlastitost kao onu najvažniju karakteristiku osobe. Boetije i Toma Akvinski smatrali su kako upravo riječ „osoba“ znači odnos, relaciju. Njihovo se učenje stoga naziva ontološki personalizam koji pokazuje kako su za ljudsku osobu bitna četiri temeljna odnosa: unutarosobni odnos ili odnos sa samim sobom; međuosobni (interpersonalni) odnos ili odnos sa svim drugim ljudima; kozmički (ekološki) odnos, to jest odnos sa svime što nije čovjek, a postoji u svijetu i na kraju transcendentalni ili religiozni odnos, to jest odnos prema najvišem biću - Bogu. ${ }^{309} \mathrm{U}$ novije se vrijeme spominje još jedna vrsta personalizma uz onaj ontološki - pojavljuje se i tzv. dijaloški personalizam koji uključuje i druge osobe u taj međuodnos jedne osobe s drugom osobom, osoba živi u dijalogu s drugim ljudima i tako i ostvaruje. ${ }^{310}$ Pritom autonomija ili neovisnost svake osobe proizlazi iz činjenice da je svaka osoba biće obdareno razumom i svojim aktom bivstvovanja. Toma Akvinski ističe da svako razumno biće ima suverenost nad svojim činima, odnosno svako biće jest gospodar svojih čina. ${ }^{311}$ Prema Welteu, čovjek je slobodno biće, no ta sloboda isto tako nije neograničena $\mathrm{i}$ ona je uvijek jedan od aspekata naše naravi. Ljudska je osoba neponovljiva i svojom slobodom može upravljati svojom savjesti i svojim razumom koji ju vodi ispravnim putem

\footnotetext{
${ }^{306}$ LUCAS R., Antropološki status, str. 77.

${ }^{307}$ Usp. BERDJAJEV N. A., Ja i svijet objekata, prev. Thaller N., KS, Zagreb, 1984., str. 132.

${ }^{308}$ DADIĆ B., KNEŽIĆ I., Metafizička istraživanja o osobi, str. 563.

${ }^{309}$ Usp. Isto, str. 565.

${ }^{310}$ Usp. Isto, str. 565.

${ }^{311}$ Usp. Isto, str. 567.
} 
prilikom odlučivanja. U nastavku rada vidjet ćemo kako to Welte ucjepljuje govor o slobodi osobe koja se svakako tiče čovjekova postojanja.

\section{Sloboda i postojanje - temeljna polazišta i naglasci kod B. Weltea}

\subsection{Uvodna razmatranja i postavljanje problema}

Welte ističe kako je sloboda temeljna pojava ljudskog postojanja. Uz svijest ona dolazi do svojeg očitovanja od početaka onog ljudskog, odnosno bitno je vezana uz početke same kulture uopće. ${ }^{312}$ Pitanje slobode temeljno je pitanje filozofske antropologije jer se u najdubljoj osnovi tiče čovjeka i njegova postojanja. Welte je mišljenja kako je u današnje vrijeme potrebno ponovno postaviti pitanje o slobodi te propitivati što je to sloboda. Tradicionalno se razumijevanje slobode dovodi u pitanje zbog napretka suvremene znanstvene svijesti, i to posebice pod utjecajem moderne biologije i fizikalnog poimanja mentalnog uopće. S ove točke gledišta prvi su put došli do izražaja određujući i time, čini se, ograničavajući, ako ne i ukidajući aspekti u strukturi ljudskog postojanja - ukidajući jer slobodu promatraju tek kao umišljaj, odnosno s druge strane kao evolucijski učinak. Navedene su rasprave bile intenzivirane i u Welteovo vrijeme, stoga on problematiku slobode uzima kao iznimno važnu za cjelokupni sklop promišljanja o čovjeku. Međutim, isto tako je naš filozof religije uvjerenja da bi pitanje slobode trebalo preispitati s osvrtom na snage odlučnosti koje su se pojavile, a s obzirom na njezino negiranje. Zato on donosi nekoliko bitnih polazišta s kojih je potrebno tumačiti slobodu kao jednu od temeljnih danosti ljudske osobe u okviru njezina postojanja. Prva dimenziju koju naš filozof u ovim razmatranjima ističe jest da je svaka ljudska osoba i prije bilo kakvog razmišljanja o slobodi, pa i iskustva o njezinoj slobodi, označena kao eminentno slobodna, kao nadarena za slobodu, razlikujući se time od svih ostalih bića. ${ }^{313}$ To je jedna prevladavajuća svijest, poglavito klasičnog (svakako kršćanskog) filozofskog pogleda o slobodi, međutim, istovremeno je upravo suvremenost obilježena time da u njoj vlada nejasna misao o tome što je to točno sloboda. S obzirom na navedenu suvremenost, sloboda se redovito razumijeva negativno, u smislu kako čovjek nije vezan - to znači da nije pod vlašću fizičkih ili mentalnih mehanizama niti pod bilo kojom drugom očitom vanjskom prisilom. Suvremeni je pojedinac jednostavno „ljubomoran“ na svoju slobodu i takvim ga se promatra. Kada kažemo ljudska osoba, tada prvo na što

\footnotetext{
${ }^{312}$ Usp. WELTE B., Gesammelte Schriften I/1 Person, 17-18.

${ }^{313}$ Usp. Isto, str. 18.
} 
pomislimo jest razumsko i eminentno slobodno biće, ali u apsolutnom smislu. Vlastitoj se slobodi ne smije ništa pretpostaviti. Nju se ne može ni za što žrtvovati, čak ni za volju zdravlja, takvo je suvremeno uvjerenje koje nije rijetko. ${ }^{314}$

Pojam ljudskog dovodi se dakle u tijesnu vezu sa slobodom. Welte zato kratko sažima svoju misao i kaže kako „sve što se može nazvati onim što je u ljudima specifično ljudsko, što je uistinu ljudsko, i u pojedinačnom i u ukupnom kontekstu, povezano je sa slobodom“. 315 Konstatirajući pak tu povezanost, mi zapravo u prvom pogledu vidimo sveobuhvatan, konstitutivni značaj raširenog razumijevanja slobode za cijelo ljudsko postojanje. Sloboda je u tom smislu jednostavno pozitivna karakteristika ljudskog postojanja. Prema tom shvaćanju, ona je ta koja karakterizira čovjeka kao takvog u njegovoj bîti, a time i kao cjelinu. Upravo ona, uz svijest, daje sveobuhvatno i cjelovito tumačenje čovjekova postojanja. Međutim, za razliku od ovog filozofskog tumačenja postojanja suvremeni, tzv. „znanstveni“, pogled na slobodu, vođen već spomenutom prirodnom znanošću te uglavnom slijedeći pozitivne društvene znanosti, poput psihologije i sociologije, tvrdi da se ljudski život i ljudsko ponašanje u svojoj osnovi određuju vezama, to jest uvjetovanostima koje u konačnici ne proizlaze iz ishodišta čovjekove osobnosti, odnosno onog ljudskog »ja«, već su prilično oblikovane onim što leži ispred i izvan našeg »ja« i naše svijesti. Sveobuhvatni svjetski znanstveni napor nastoji pokazati da ljudsko postojanje u svom ponašanju vode i kontroliraju iste sile, premda u drugačijoj kombinaciji, koje posvuda grade, kontroliraju i određuju materijalni kozmos, kao i društvene strukture uopće, tako naš autor kaže. ${ }^{316}$ Te su sile prvotno materijalne prirode ili, jasnije s obzirom na čovjeka, biokemijski procesi u njegovu mozgu, to jest svijesti, te nadalje društveno naslijeđe u koje je čovjek bez svoje volje smješten. Welte uzima ova znanstvena tumačenja ozbiljno, međutim, ne i apsolutno, što je iznimno važno istaknuti. Na tragu klasične, poglavito kršćanske filozofije, čovjek je za Weltea u osnovi duhovno i cjelovito te posljedično u osnovi slobodno biće, stoga on pristupa ovim znanstvenim tumačenjima s dužnim uvažavanjem, no nikako ne apsolutno, to jest da bi ih u ime bilo koje ,znanstvenosti“ nekritički preuzeo.

\footnotetext{
314 Upravo je u tijeku nastanka ovog rada (2020. g.) na djelu sveopća pandemijska kriza uzrokovana koronavirusom. Pri tome vlade pojedinih zemalja, da bi istu spriječile, uvode restriktivne mjere koje u isto vrijeme ograničavaju ljudske slobode, poglavito s obzirom na slobodu kretanja. Istovremeno pak uvođenjem ovih mjera raste i nezadovoljstvo građana, tako da su u pojedinim zemljama sve učestaliji (masovni) protesti upravo zbog temeljnog razloga područja kojeg se ovdje dotičemo: ugrožavanje slobodâ. Svakako u problematiku opravdanosti ovih protesta ne želimo dublje ulaziti, već samo naglasiti, odnosno ponoviti (djelomično istaknutu) tezu da je suvremeni čovjek jednostavno ,ljubomoran na svoju slobodu“.

315 Usp. WELTE B., Gesammelte Schriften I/1 Person, str. 19.

${ }^{316}$ Usp. Isto, str. 20-21.
} 
Također se čini - iz biofizičkih, kibernetski razumljivih skupova pravila i kontrolnih mehanizama, kao i iz razmatranja nastalih ponašanja, te u svjetlu razvojne misli - da ljudski element, uključujući specifično ljudsko ponašanje, danas u velikoj mjeri, možda čak i u cijelosti, pripada ovom kontekstu. ${ }^{317}$ Za znanost i znanstvene krugove tako ljudski život i postojanje predstavljaju određeni biološki sustav koji, iako pripada višem stupnju razvoja, ne pripada bitno drugačijoj vrsti sustava. ${ }^{318}$ Ovim se, međutim, ideja odlučnosti, i to ponajprije fizički i kemijski koncipirana odlučnost, gura sve snažnije i sveobuhvatnije protiv naivnog ljudskog razumijevanja slobode i svih njezinih posljedica. Sumnja koja se, naravno, rijetko izražava proizlazi iz toga da je ta svijest o slobodi možda samo privid proizveden tipičnim ljudskim ponašanjem koje je pak određeno u biofizičkom i biokemijskom sustavu ljudi. Kao posljedica toga javlja se još dalekosežnija sumnja, naime, da sve što se odnosi na svijest o slobodi i što se čini samo razumljivim postaje također varijabilno i tek kao puki (čovjekov) konstrukt, poput morala i zakona, vjere i ljubavi te religije. ${ }^{319}$ Ideja o određivanju životnih procesa koju njeguje egzaktna znanost posljedično također postaje osnovni tip ljudskog postojanja u cjelini. Danas se čini kako je deterministička interpretacija ljudskog postojanja potvrđena znanstveno utemeljenom upravljivošću ljudskim bićima koja postaje sve očitija. Svoje postavke suvremena prirodna, pozitivistička znanost o čovjeku pokušava dokazati eksperimentima u kojima iščitava biokemijske strukture i međusobne odnose pojedinih entiteta, po klasičnom ključu uzrok-posljedica te konkretnije uz pomoć primjerice lijekova ili odgovarajućih ključnih podražaja i sekvenci podražaja. Welte upozorava na to kako se može učiniti da je ljudskim bićem uistinu postalo u velikoj mjeri moguće upravljati kad se jednom prepoznaju i dokopaju biokemijske odrednice i odrednice ponašanja njegove prirode. ${ }^{320}$ Cjelokupno tumačenje ljudskog postojanja koje iz ovog proizlazi ima eminentne posljedice na ono što čovjek jest i što će biti. Sažeto se suprotstavlja drugoj ukupnoj interpretaciji onog što je čovjek u cjelini, a koja se temelji na načelu slobode i koja zauzvrat ima posljedice na ono što čovjek jest i što će biti.

Prilikom ovog tumačenja Welte želi upozoriti na to kako se ne može ljudsko postojanje i život dokazati čisto na znanstveni način te korištenjem fizikalnih i kemijskih sila. U tom bi se slučaju dogodilo ugrožavanje temeljnih čovjekovih odrednica, već spomenutih, slobode, zakona i morala. To su one odrednice koje čovjekovu osobnom životu i postojanju

\footnotetext{
${ }^{317}$ Usp. Isto, str. 22.

318 Usp. Isto, str. 21.

${ }^{319}$ Usp. Isto.

${ }^{320}$ Usp. Isto, str. 69.
} 
daju humanost i općenito humanu karakteristiku. Zato još jednom treba napomenuti kako Welte uzima ova znanstvena shvaćanja kao važna, no nikako apsolutno prihvatljiva, stavljajući čak i u pitanje navodnu znanstvenost jer znanost ovdje (u navedenom pristupu čovjeku) nastupa upravo ideološki - djelomične postavke (koje i ne moraju biti netočne) poopćava, to jest apsolutizira na sva područja humanog, odnosno humanističkog.

Čini se da se dvije raširene i impozantne vrste interpretacije ljudskog postojanja uzajamno isključuju, ali se istodobno mora uputiti prigovor protiv svakog takvog isključivanja u ime čovjeka i njegove čovječnosti. Prema Welteu, može se kazati kako obje vrste tumačenja ljudskog postojanja treba uzeti kao one koja idu jedna uz drugu i nema mjesta za isključivanje nijedne od navedenih sastavnica slobode koje se tiču ljudskog postojanja. Welteovim riječima, i jedna i druga se čine toliko ljudske da se ničeg ne možemo odreći a da ne izdamo svoju ljudskost. ${ }^{321}$

Welte više puta ističe da je sloboda pozitivna sastavnica ljudskog postojanja i kao takvu ju treba i razumijevati. ${ }^{322}$ Pozitivnost slobode, koju ovdje u odnosu na Weltea i njegovo viđenje religije u tom kontekstu detaljnije elaboriramo, želi reći da se čovjek prije svakog određenja i definiranja ne postavlja kao ono biće koje biva pod ikakvom prisilom, odnosno nije izložen fizičkim ili mentalnim mehanizmima niti radikalno drugim društvenim ograničenjima, na koja bi se mogao pozivati lišavajući sebe odgovornosti. U suprotnom to znači prihvaćanje u temelju uvjetovanosti ljudskog bića, a to znači „suptilnih“ i „,nevidljivih“ ograničenja u vidu (svakodnevne) prisile; svrstali bismo se u pobornike tzv. negativnog vida slobode. Posebno je to važno uočiti zbog razmatranja o religiji u okviru Welteova viđenja religije po sebi. Naime, olaka i pojednostavljena tumačenja pojmove religije i slobode stavljaju religiju i čovjeka nasuprot jedno drugom, odnosno - jednostavnije - religiju promatraju kao prisilu i posljedično nametnutu te time otuđujuću stvarnost u odnosu na čovjeka. Čovjek je, naprotiv, u Welteovim tumačenjima, biće slobode i biće religije, a (njegovo) opće uvjerenje o slobodi jest ono iz kojeg proizlazi čovjekova savjest i odgovornost, bez kojih upravo sva njegova (čovjekova) religioznost pada u vodu. ${ }^{323}$ Tako kroz odgovornost koja proizlazi iz slobode čovjek biva sposoban uvidjeti razliku između onog što nazivamo dobro spram onog što bismo označili kao zlo, koje se također nužno veže uz religiju (dobro), odnosno njezine instrumentalizacije (zlo). Ili, Welteovim riječima, „sloboda koja je ovdje u igri ne smije se shvatiti samo negativno kao nevezanost, nego također

\footnotetext{
${ }^{321}$ Usp. WELTE B., Filozofija religije, str. 22.

${ }^{322}$ Usp. WELTE B., Gesammelte Schriften I/1 Person, str. 70.

${ }^{323}$ Usp. Isto, str. 22.
} 
pozitivno, naime kao osobni polet i slobodno predavanje“. ${ }^{324}$ Samo se u osobnoj slobodi može govoriti i o osobnom odnosu i samo tamo gdje je već probuđena ontološka razina tog odnosa može se uočiti, reći će Welte, ono najsvojstvenije svakog ljudskog pojedinog »ti« i samo tako osoba biva sposobna proniknuti u tajnu svoje transcendencije. ${ }^{325}$ Ovim se pokazuje kako naš filozof religije slobodu i religiju promatra kao dva krila jednih pluća, pri čemu se može disati, odnosno živjeti religioznost tek u svjesnoj i slobodnoj odluci za Transcendenciju. Dakako, slobodna odluka uvjetuje i slobodno izvršavanje religije, što je i više nego jasno.

\subsection{Filozofijsko-teološke eksplikacije Welteova viđenja slobode i njezina daljnja određenja}

Nakon što je s dužnom pozornošću sine ira et cum studio ukazao na prirodoznanstvene momente i njihovu nedorečenost, odnosno problem njihova poopćavanja, naš se filozof religije okreće detaljnoj analizi pojma slobode jer je ona, uz „svjesnost“ odnosa prema Transcendentnom, krucijalna s obzirom na ono što nazivamo izvršenje religije uopće. Izvršenje religije u Weltea znači upravo čovjekovu spremnost na susret i razgovor s Bogom kroz razgovor, molitvu i kult. U tom kontekstu valja spomenuti Emericha Corteha, znamenitog insbruškog isusovca i teologa, bliskog Welteu po razmišljanju o slobodi. Na Welteovu tragu, Coreth $^{326}$ piše kako je sloboda danas postala temeljni pojam kojim se želi izraziti čovjekovo samorazumijevanje i samoostvarenje. ${ }^{327}$ Pojam slobode danas se tumači različito te će u duhu teološkog poimanja Welte reći da nijedan od njih ne treba apriori odbacivati - uključujući, dakako, i onaj znanstveni dok ne ugrožava dostojanstvo koje čovjeku po rođenju pripada. Riječ sloboda osnovni je pojam dakle kojim se izriče čovjekovo razumijevanje sebe u odnosu prema drugima, odnosno društvenoj kontekstualnosti uopće. Sloboda je postala temeljnim zahtjevom čovjekova života i života dostojna čovjeka. ${ }^{328}$ Pojavom svijesti o slobodi u prvi plan dolazi promišljanje o političkoj i etičkoj slobodi pripadnoj svakom čovjeku. Dostojanstvo koje je fundamentalno svakoj ljudskoj osobi kršćanski je novum koji proizlazi iz religiozne svijesti i, kako je to već Hegel primijetio,

\footnotetext{
${ }^{324}$ WELTE B., Filozofija religije, str. 159.

${ }^{325}$ Isto, str. 161.

${ }^{326}$ Emerich Coreth, austrijski isusovac i filozof, profesor i rektor Sveučilišta u Innsbrucku u drugoj polovici 20. stoljeća, koji je mnogo govorio o osobi i slobodi te temama kojih se, već prije njega, doticao i o kojima je progovarao Welte.

327 CORETH E., Smisao čovjekove slobode, u: Obnovljeni život, 53 (1998) 4, str. 391.

${ }^{328}$ Isto, str. 392.
} 
usađen u svjetsku bit. ${ }^{329}$ Fundamentalno dostojanstvo koje zahvaljujući tome prepoznajemo u svakom pojedincu polazište je za vanjsku, to jest političku slobodu kakvu danas uživamo. Taj smjer kojim ljudi nastoje biti oslobođeni nastavlja se, među ostalim, i u postmodernoj misli koja, zanimljivo, svoj iskon pronalazi još u Ockhamovu nominalizmu. ${ }^{330}$ Ona pak govori o čovjeku kao radikalno »samostvarajućem jastvu«. Taj je koncept, poglavito u suvremenosti, iznimno primamljiv, međutim, konačni je rezultat tog pravca reduciranje slobode isključivo na pitanje jedne ljudske sposobnosti - volje. ${ }^{331}$ Nije teško ovdje odgonetnuti Ockhamovsku primjesu, odnosno utjecaj, na koji Welte s pravom ukazuje. U tom se smjeru otvara put prema raspadu kulture jednog ustrojenja koje smo stoljećima gradili. Za razliku od toga treba osigurati okruženje koje će omogućiti vanjsku (objektivnu) i poticati unutarnju (subjektivnu) slobodu. ${ }^{332}$ Welteov pojam „raspada kulture“ nimalo nije pretjeran, već upravo proročki. Naime, kulturu ne čini mnoštvo pojedinaca sabranih na nekom prostoru - pri čemu je svaki pojedini od njih upućen na samog sebe, njegujući svoju vlastitu slobodu kao nekakav kult. Nasuprot tomu kulturu, odnosno zajednicu, čine, istina, slobodni pojedinci, ali u odnosu - a to znači dijelom žrtvujući vlastitu slobodu te, dakako, upućeni u bitnome na vrijednosti koje proizlaze iz tih odnosa, kao i života općenito. Zato je Welte bio mišljenja kako unutarnja sloboda mora biti utemeljena na nečem što je objektivno, a to je moral koji proizlazi iz mudrosti utvrđene na ljudskom djelovanju, odnosu s okolnim svijetom i promatranju onog što dolazi kao rezultat suživota među ljudima.

Sloboda uređena moralom postaje sredstvo za izvrsnost, sreću i ispunjenje ljudske sudbine. Takva konkretna sloboda preduvjet je za odabir mudrog i dobrog djelovanja. Slobodna volja i odlučivanje koji su pripadni čovjeku kao osobi uvijek nose u sebi i mogućnost krivog odabira ili izabiranja zla umjesto dobra. Welte je stoga mišljenja kako slobodu moramo uvijek promatrati kao neodvojivu od odgovornosti u kontekstu nas samih i drugih s kojima dijelimo suživot. Spomenuti E. Coreth mišljenja je da smo zbog tako goleme, pluralistički distribuirane moći, uz potencijalno dobro izloženi opasnosti društvenog kaosa. ${ }^{333}$ U suvremenoj slici svijeta koja pomalo nalikuje onoj strogo mehanicističkoj gdje je sve prožeto nužnošću prirodozakonskog kauzaliteta samo se ovdje, u pogledu društvenosti institucijama koje prožimaju svaki aspekt života, objektivna sloboda sve više umanjuje i nema

\footnotetext{
${ }^{329}$ Usp. WELTE B., Gesammelte Schriften I/1 Person. O Hegelu Welte posebno govori na str. 97., 124., 210. i 264.

${ }^{330}$ CORETH E., Smisao čovjekove slobode, str. 391.

${ }^{331}$ Isto, str. 391.

${ }^{332}$ CORETH E., Smisao čovjekove slobode, str. 391.

${ }^{333}$ Usp. Isto, str. 393.
} 
mnogo prostora za slobodno djelovanje. ${ }^{334}$ Nepovoljna situacija izvire iz toga što sve više dobiva na važnosti subjektivna sloboda i s njom u vezi ukidanje zabrana - sloboda biva neograničena za pojedinca koji može činiti što želi, po svojoj volji. Taj glasoviti „liberté“ koji odzvanja još od Francuske revolucije odnosi se na apstraktnu slobodu, to jest na onu koja se oslobađa od konkretnih vezanosti koje su određene stvarnim stanjem, dakle od stvarnih društvenih mogućnosti. ${ }^{335} \mathrm{U}$ ime takve slobode odbacuju se autoriteti, norme i tradicije utemeljene na kompetenciji i čvrstim, ali implicitnim racionalnim razlozima što znatno otežava obranu istih vrijednosti. ${ }^{336}$ Takva sloboda, na koju Welte upozorava, često biva reducirana na samovolju, a Coreth o istoj kaže sljedeće: „Ona uopće ne dostiže bit i smisao konkretno ljudske, smislom ispunjene slobode koja je upravo takva zbog toga što je vezana za vrijednost i normu“ ${ }^{337}$ Osim anarhističkih tendencija u suvremenosti, totalitaristički režimi su također primjer provođenja samovolje, gdje sloboda po sebi postaje bezvrijedna i zanemaruju se sve istinske vrijednosti i moralne norme.

Predočeno Corethovo promišljanje o slobodi Welte izvrsno povezuje s Kantom koji upućuje na to da je moralna dužnost neposredno dana u čovjekovoj svijesti te da se ona obraća slobodi, a ne obrnuto. ${ }^{338}$ Iako pomalo formalistički, Kantova je koncepcija uvelike dala izvorni smisao slobode, a to je obveza. Nema slobode ako se za nešto, poglavito vrijednost, ne vezujemo. Upravo u tome smislu branimo ovdje tezu s Welteom i Corethom da sloboda nema ništa zajedničko sa samovoljom pojedinaca ili pak sustava. Filozof će iz Königsberga stoga ukazati na to da je sloboda transcendentalni uvjet mogućnosti moralnog djelovanja. ${ }^{339}$ Sloboda je upravo zato nužno moralna sloboda koje smo svjesni isključivo kao uvjeta moralnog htijenja. ${ }^{340}$ Ona je još u starogrčkoj misli bila razumijevana kao preduvjet moralnog djelovanja, a kršćanski je shvaćana kao sposobnost za dobro. $\mathrm{Na}$ taj način razumijevana, sloboda ne ostavlja prostora za bilo kakvo odvajanje od onog što nazivamo moralnost i moralne norme. Kada se radi o poimanju slobode i samovolje, Welte spominje na nekoliko mjesta i Hegela te njegovo tumačenje u kojem Hegel strogo razlikuje pojam slobode i pojam samovolje. Samovolja uglavnom ide za nagonima i sklonostima koje osoba posjeduje i zato nije slobodna, već ovisi dakle o prirodnim porivima i okolnostima u kojima osoba

\footnotetext{
${ }^{334}$ Usp. Isto, str. 391.

335 Usp. Isto, str. 393.

336 Usp. Isto, str. 393.

${ }^{337}$ Usp. Isto, str. 393.

${ }^{338}$ Usp. WELTE B., Gesammelte Schriften I/1 Person. O Kantu posebice na stranici 53., 85. i 86.

${ }^{339}$ Usp. CORETH E., Smisao čovjekove slobode, str. 393.; Usp. WELTE B., Gesammelte Schriften I/1 Person, str. 53.

${ }^{340}$ Usp. CORETH E., Smisao čovjekove slobode, str. 393.
} 
živi. ${ }^{341}$ Hegel će reći „bit duha je sloboda“ - sloboda, duh i razum u osnovi su jedna cjelina, pa se sloboda vodi uvidom u ono što je dobro i što treba činiti i zbog toga su pravo, moral i socijalne dužnosti pozitivni uvjeti slobode, a ne negativna ograničenja, što držimo krucijalnim u promatranju slobode. ${ }^{342}$ Objektivna je sloboda u jednom smislu ohrabrenje za ostvarivanje subjektivne slobode, dok $\mathrm{u}$ drugom smislu ona sama proizlazi iz subjektivnih sloboda mnoštva koje se, ako je vođeno moralnom istinom, uspješno ujedinjuje u kulturi. ${ }^{343}$

Važnim se također nameće promotriti govor o mogućnosti slobode kod Maxa Schelera koji je uočio kako sloboda jednostavno proizlazi iz čovjekove biti u kojoj on posjeduje temeljnu slobodu (Grundfreiheit) koja pak prethodi svakoj slobodi htijenja i djelovanja, i subjektivnoj i objektivnoj. ${ }^{344}$ E. Coreth kaže, u oslanjanju na M. Schelera, „da čovjek nije vezan na okolinu (umweltgebunden), zato ni na nagone (triebgebunden) poput životinje, nego je na specifičan način slobodan od okoline (umweltfrei) i slobodan od nagona (triebfrei), a zbog toga otvoren za svijet (weltoffen) ili, bolje rečeno, otvoren za bitak (seinoffen)“.345 Osoba uvijek živi u otvorenosti spram svijeta u kojem se nalazi i živi. Sloboda koja se tako razumijeva tijekom povijesti filozofije i promišljanja o čovjeku prisutna je još od Aristotela, Tome Akvinskog i Hegela sve do današnjih suvremenih zapažanja o čovjeku u okviru psihologije, antropologije itd. ${ }^{346}$ Filozofi egzistencijalizma koje Welte spominje, posebice Kierkegaard, Nietzsche i Sartre, također primjećuju kako je čovjek zapravo nedovršen (unfertig). ${ }^{347}$ To bi pak značilo da on nije vezan za određenu okolinu u kojoj živi niti je pak u teleološkom smislu dovršen, nego je uvijek otvoren mogućim ostvarenjima i vidovima samorazvoja. Svakako da čovjek odlučuje o svom ostvarenju te s tim u vezi djelovanju, no odgovornost nalaže da mora uzimati u obzir one s kojima živi u određenom okolišu i suživotu. Stoga radikalni nominalizam kao načelo svojevrsne parcijalnosti i empirije jest put prividne slobode pri čemu čovjek ovdje završava u robovanju toj istoj parcijalnosti i materijalnosti, što je svojstveno zoološkom svijetu, a ne ljudskom. ${ }^{348}$ Parcijalnost o kojoj ovdje u sklopu nominalizma govorimo čini odmak od svakog pojma istine i s njom vezane apstrakcije u vidu izdizanja iznad onog materijalnog (empirija), kao i s tim vezano općeg.

\footnotetext{
${ }^{341}$ Usp. Isto, str. 393.

342 Usp. Isto, str. 393.; Usp. WELTE B., Gesammelte Schriften I/1 Person, str. 53.

${ }^{343}$ CORETH E., Smisao čovjekove slobode, str. 394.

${ }^{344}$ Isto, str. 394-395.

${ }^{345}$ Usp. Isto, str. 395.

${ }^{346}$ Usp. WELTE B., Gesammelte Schriften I/1 Person, str. 14-264. O Aristotelu posebice na 14., 48., 93., 164. i 177. str.; o Hegelu 97., 124., 210. i 264. str.; o Tomi Akvinskom posebice na 14. i 49. str.

${ }^{347}$ Usp. WELTE, Gesammelte Schriften I/1 Person, str. 80., 81., 91.

${ }^{348}$ Usp. CORETH E., Smisao čovjekove slobode, str. 398.
} 
Međutim, nasuprot tome uvjet slobode je istina, kao što je i uvjet za spoznaju istine sloboda. 349

Svakako valja nadalje, bez „upadanja“ u nominalistički koncept, reći da je čovjek slobodan svoj život sam oblikovati samostalno i prema vlastitom nadahnuću, međutim, s bitnim naglaskom orijentiranja i uvida u temeljne istine, odnosno prema istinskoj spoznaji. Ovdje se ne radi o nametanju svjetonazora u vidu religije ili morala, već odgovornosti i napora u (svakodnevnom) spoznavanju temeljnih vrijednosti i njihove primjene $u$ svakodnevnom životu. Svakako da institucije i znanost stoje tome u službi, kao i službi čovjekova cjelokupnog života. ${ }^{350}$ Pojam istine ne odnosi se nadalje samo na fizikalnobiološku stvarnost koja se proučava, a kako to danas promiču neki suvremeni pravci poput scijentizma, radikalizirajući do te mjere pojmove znanosti i (tehničke) istine, gotovo da ne ostaje nikakav prostor za čovjeka kao duhovno-misaono, a time i slobodno biće. Pojam istine u kontekstu slobode želi ukazati na ontološku gustoću vrijednosti kao onog prema čemu je čovjek kao spoznajno i moralno biće usmjeren i posljedično obvezan činiti. Iz tako razumijevane istine proizlaze i etičke norme i pravila koja omogućuju čovjeku ispravno oblikovanje vlastite slobode i u okviru toga samorazvoja. Sloboda se naposljetku treba shvatiti u smislu temeljne slobode vođene razumom koja se ostvaruje u slobodi odlučivanja i djelovanja s ciljem samoostvarenja koje ne proizlazi iz imanentnog zatvaranja u sebe, već iz iskustva uzajamne subjektivnosti, odnosa »ja-ti« u buberovskom smislu - spoznajući i nadilazeći samog sebe kroz druge, što je jedan vid temeljne spoznaje o kojoj je bilo netom riječi. ${ }^{351}$ Ovaj odnos »ja« spram »ti«, Welteovim riječima, treba nas dovesti k tome da drugu osobu, onu koju označavamo sa »ti«, uvijek trebamo, u duhu I. Kanta, promatrati kao svrhu, nikako kao sredstvo, što je primjerice daljnji vid (temeljne) spoznaje. Onoliko koliko čovjek uspije više nadići samog sebe, to se više uspijeva ostvariti i pronaći svoju svrhu. Ljudska sloboda dakle podliježe moralnoj dužnosti i time istini prema Welteu. U tom smislu, uz govor o istini, ide već spomenuta moralnost. ${ }^{352}$ Štoviše, nužnost slobode je moralnost koja u svojoj osnovi počiva na obligatornom karakteru. Sloboda stoga, možemo se složiti s mišljenjem E. Coretha, nije samo odluka između dobra i zla, nego odluka koja je po sebi odsjaj slobode,

\footnotetext{
${ }^{349}$ Usp. Isto, str. 399.

${ }^{350}$ Usp. CORETH E., isto, str. 400.

${ }^{351}$ WELTE B., Gesammelte Schriften I/1 Person. O Buberu posebice na str. 97. i 98.

${ }^{352}$ Moglo bi se ovdje činiti da Welte zastupa izvjesnu „metafiziku istine“ kada ju (po)vezuje s moralnošću. Međutim, on je ovdje u svojevrsnoj dosljednosti na tragu moralne teologije koja zastupa objektivni moralni red i njegovu upućenost na istinu, što znači nadalje da naš filozof iz Freiburga zastupa, u eminentno filozofskom pogledu, jedan etički realizam.
} 
mogućnost posezanja između dobrog i boljeg ili najboljeg. ${ }^{353}$ Odlučujemo se dakle u slobodi za ono što je postavljeno kao cilj i (moralna) obligacija. Zaključno, a na Welteovu tragu, treba reći kako se čovjekovo samoostvarenje ne zbiva nikad tako da je čovjek usmjeren na sebe samog ili da bi iskorištavao drugog da bi postigao vlastitu svrhu. Upravo suprotno, čovjek svoje samoostvarenje i slobodu dostiže u djelatnom zauzimanju za drugog radi njega samog. Djelatno čovjekovo zauzimanje za drugog, dakako, proizlazi - kako spomenusmo - iz komunikacije s drugim čovjekom, iz susreta, to jest odnosa ,ja“ spram „ti“. To pronalazimo i u Novom zavjetu kada se govori o slobodi djece Božje koja se daju voditi njegovim Duhom. ${ }^{354}$ Takvim sebe-zaboravnim zalaganjem pridonosi se društvenim uvjetima u kojima se na najbolji način može razvijati i osobna sloboda pojedinca. ${ }^{355}$ Sve rečeno očituje se u tome da je upravo sloboda temeljna mogućnosti ljudskog i međuljudskog života. ${ }^{356}$ Već u starogrčkoj misli, u Ksenofana, postoji misao kako se sloboda očituje u izboru najbolje mogućnosti u konkretnoj situaciji u kojoj se osoba nalazi. Sloboda shvaćena kao konkretna sloboda, vezana moralnošću, stječe se pak navikavanjem na ispravne odluke koje će proizaći iz osjećaja odgovornosti. ${ }^{357}$ Zato se treba prisjetiti i Kanta koji je rekao da se bit slobode ogleda kroz čovjekovo odrastanje, pri čemu filozof iz Königsberga misli na obvezu ljudskog i moralnog napredovanja, stoga poentira izričajem ,kako bismo bili slobodni moramo nadići samonametnutu maloljetnost “. ${ }^{358}$ Slično Welte sažima svoju misao kada se radi o kršćanskom misliocu koji se bavi filozofijom: „on snagom svoje vjere može kršćansku poruku učiniti temeljem svojeg opstanka. Mislilac pri tome uvijek zadržava snagu vlastita mišljenja te se i smije i mora njome poslužiti“، 359

Na tragu prethodnih promišljanja u kojima smo slobodu „oslobodili“ od parcijalnosti i materijalnosti, to jest specifično biokemijskih procesa u čovjeku, što znači svega onog što ju determinira na nešto drugo njoj neprirodno, slobodu možemo u okviru čitave filozofske tradicije vezati upravo za ljudski duh, odnosno njegovu specifično duhovnu dimenziju. Uz duh se pak nužno vezuje um (engl. mind). Tako se prilikom elementarnog razlikovanja od drugih živih bića čovjek posebno ističe svojim umom koji ga čini nezamjenjivim, posebnim i vrijednim. Osoba po umu postaje svjesna vlastitog postojanja te, gajeći ono vrijedno u sebi,

\footnotetext{
${ }^{353}$ Usp. CORETH E., Smisao čovjekove slobode, str. 401.

${ }^{354}$ Usp. WELTE B., Gesammelte Schriften I/1 Person, str. 90.

${ }^{355}$ Usp. CORETH E., Smisao čovjekove slobode, str. 402.

356 Usp. Isto, str. 400.

${ }^{357}$ Usp. Isto, str. 400-402.

${ }^{358}$ Usp. Isto, str. 396.; usp. i KANT I., Kritik der reinen Vernunft, 51-54.; 238-239.; gdje Kant govori upravo o ovom vidu moralne slobode. Moralna je sloboda, prema Kantu, isključivo vezana uz bezuvjetni moralni zakon, točnije transcendentalni uvjet mogućnosti moralnog djelovanja.

${ }^{359}$ Usp. WELTE B., Filozofija religije, str. 35.
} 
biva sposobna razlikovati dobro i zlo i to da postoji onaj drugi „ti“ koji posjeduje sve što i ,ja“. 


\section{DIO RADA}

\section{Fenomenologija i filozofija religije - sjecišta i razmeđa}

Fenomenologija religije je znanost o religioznim fenomenima. Fenomen religije u životu čovjeka, kao i čovjekov pokušaj shvaćanja religije zabilježen je od samog početka ljudske povijesti. U tome se smislu možemo složiti $\mathrm{s}$ autorima koji ističu sljedeće: „Fenomenologija religije obuhvaća istraživanja religioznih fenomena u području povijesti religije, religioznu svijest u psihologiji religije, religiozno ponašanje u društvu (sociologija religije) te filozofska istraživanja o biti religije (filozofija religije)“.360 To su temeljni filozofski pravci u okviru kojih ćemo se kretati prilikom tumačenja Welteove fenomenologije religije. Fenomenologija je za Weltea, ,iznašanje u pojavak svega onoga s čime se susrećemo“. ${ }^{361}$ Welteova fenomenologija prikazuje kako gledati sve one stvarnosti bitne za religiju. S. Kušar ističe kako „Welteova fenomenologija u jednakoj mjeri obuhvaća teoriju i praksu, um i djelovanje“. ${ }^{362}$ Upravo je fenomenologija izvrstan način kako govoriti o biti religije kao takve. Welteova fenomenologija pokazuje kako mi u svagdašnjem djelovanju koje je svjesno svoje odgovornosti - odgovaramo tajni (Bogu) koja nas se bezuvjetno tiče. ${ }^{363}$ U tome smislu Kušar nastavlja kako Welte „vodi čitatelja pred kršćanskog Boga objašnjavajući bitne korake i pojmove koji vode ka ispravnom razumijevanju religije.“364 Čovjekov odgovor Bogu biva dijaloški u obliku vjere, molitve i kulta, stvarnosti koje će biti objašnjene u nastavku ovog dijela rada.

Welteova filozofija religije proizašla je iz predavanja koja je Welte držao od 1962. do 1973. godine. On sam ističe kako je svake godine nadopunjavao svoja predavanja o filozofiji religije jer su mu se kroz predan rad i posvećenost svake godine otvarali novi vidici. ${ }^{365}$ Zato započinjemo s fenomenologijom religije koja je zapravo izrasla iz Welteova dugogodišnjeg bavljenja filozofijom religije. Kroz mnoga njegova djela i zapise uviđa se činjenica kako je bilo dobro i uputno dotadašnju filozofiju religije prozvati fenomenologijom religije. Treba odmah reći kako to ne znači da je naziv filozofija religije nepotpun ili nedostatan. Upravo suprotno. Navedeni pojam ostaje važnim elementom njegova bavljenja religijom, međutim, upravo su se tijekom tog bavljenja otvarali novi vidici razmatranja tema religije, i to bitno

\footnotetext{
${ }^{360}$ LASIĆ H., Fenomenologija i filozofija religije, Biblioteka Filozofski niz, Zagreb, 2012., str. 9.

${ }^{361}$ WELTE B., Filozofija religije, prev. Kušar S., Matica hrvatska, 2016., Zagreb, str. 11.

${ }^{362}$ Isto, str. 11.

${ }^{363}$ Isto.

${ }^{364}$ Isto

${ }^{365}$ Usp. Isto, str. 17.
} 
kroz prizmu fenomenološke misli. Upravo zbog dosljednosti te svojevrsnog pojmovnog i sadržajnog preciziranja, kao i svojevrsnog kvalitativnog napredovanja u razradbi, Welte odlučuje da svoje bavljenje religijom označi kao fenomenologiju religije. Fenomenologija je religije dakle, prema Welteu, točniji i precizniji naziv za sve ono što je pokušao izreći prilikom bavljenja religijom uopće. Međutim, prije razradbe Welteova fenomenološkog pristupa religiji važnim se nameće reći nešto o fenomenologiji kao filozofskoj disciplini uopće. Tu nam se kao nepreskočiv nameće, jasno, Edmund Husserl.

\subsection{Općenito o metodi fenomenologije - Edmund Husserl kao začetnik}

U govoru o fenomenologiji potrebno je pobliže objasniti i samu metodu fenomenologije. Početkom XX. stoljeća u filozofskim se krugovima pojavljuje Edmund Husserl koji uvodi novi način filozofiranja. Husserl počinje isticati važnost onog „očitujućeg“ pojma fenomena u procesu spoznaje uopće, pokušavajući tako dati temeljene odrednice spoznajnog procesa uopće kako u humanističkim znanostima poput filozofije, tako i prirodnim. Nije stoga teško zaključiti da će Husserlovo bavljenje spoznajom uopće imati dalekosežne posljedice za mnoga područja znanja od kojih je jedan svakako i filozofija religije, i s njom pristup Bernharda Weltea kojim se bavimo. Za filozofiju Edmunda Husserla R. Ingarden ustvrđuje kako ona mijenja mnogo u tadašnjoj filozofiji, pa i kada se radi o samom stilu filozofiranja, filozofija Edmunda Husserla donosi mnogo novosti. ${ }^{366}$

Milan Uzelac ističe kako prvo što se da primijetiti u Husserlovu filozofiranju jest samopotvrđivanje volje koja mišljenje shvaća kao princip djelovanja, što pak dalje vodi k zaključku kako je Husserl filozofiju promatrao kao princip vlastite egzistencije. ${ }^{367} \mathrm{U}$ svojim Pariškim predavanjima Husserl ističe kako „onaj koji ozbiljno želi postati i zvati se filozofom, mora se barem jednom u životu pozvati na samoga sebe i pokušati u sebi izvršiti prevrat svih usvojenih znanja i ponovno ih izgraditi““. ${ }^{368}$ Ponovno propitivanje svih usvojenih znanja i zatim izgradnja istih naziva se egzistencijalni obrat u Husserla koji pak vodi daljnjem razumijevanju filozofije kao stvari onoga koji o njoj filozofira i te se upravo pitanje metode ovdje čini ključnim, dakle prilikom govora o pristupu filozofiji samoj. ${ }^{369}$ Fenomenologija kao filozofska disciplina zadobiva svoju važnost upravo kroz Husserlovo djelo Logische

\footnotetext{
${ }^{366}$ Usp. INGARDEN R., Nine Essays in Phenomenology, Springer, Netherlands, 1959., str. 179.

${ }^{367}$ UZELAC M., Fenomenologija, Veris, Novi Sad, 2009., str. 93.

${ }^{368}$ Isto, str. 93.

${ }^{369}$ Usp. Isto, str. 93.
} 
Untersuchungen, koje pruža novi smjer suvremenoj filozofskoj misli i postaje iznimno važno djelo svima koji su se bavili i još se bave fenomenologijom. U tom smislu Uzelac ističe kako je ,prednost fenomenološke metode upravo u njezinoj sposobnosti ugrađivanja u različite smjerove istraživanja gdje se upravo njezinom primjenom postižu značajni rezultati““.370 Unutar fenomenološke metode iznimno se važno pokazuje pitanje evidencije, odnosno istine.

Ova dva pojma dolaze u bliskom odnosu jer Husserl istinu smatra „evidentnom danošću“. Svakako se postavlja pitanje kako misliti evidenciju. Odgovor bi bio sljedeći: „Evidenciju ovdje treba razumijevati prvenstveno kao iskustvo o bivstvujućem; evidentno se susreće sa istinom u onome što je samorazumljivo; evidentno označava $u$ isto vrijeme ono razumljivo i ono što je stvarno, i to stvarno ne u smislu postojećega, već kao ono što se iskušava; pri tom istina nije tek objektivni korelat evidencije već samodatost predmeta“. 371 Evidencije je stoga za Husserla poglavito podudaranje istine i postojanja. ${ }^{372}$ Husserl je uviđao kako čisti matematički formalizam prirodnih znanosti ne može poslužiti za dostatno objašnjavanje stvarnosti pa se iz toga razloga okreće problematiziranju prirodnog stava kojeg postajemo svjesni tek u transcendentalnom stavu. ${ }^{373}$ Uzelac u tom smislu ističe kako je ,prvi korak pri tome eidetska redukcija kojom se dospijeva do čistih fenomena čijim se problematiziranjem tek otvara put za postavljanje fenomenološkog pitanja, gdje dolazi do izražaja već poznata transcendentalna redukcija (posebice kod Kanta i neokantovaca) koja će ukazati na potrebu onoga »ego cogito« kao posljednjeg temelja svega“. ${ }^{374}$ To bi pak dalje značilo da svaki predmet koji postoji na bilo koji način (konkretno egzistirajući ili neegzistirajući, bio on realan ili idealan, vjerojatan ili hipotetički) predmet je koji se u prirodnom stavu nalazi neposredno pred nama i koji pretpostavlja da bi filozofska refleksija bila moguća kao korelacijska veza između onog danog predmeta, na jednoj i njemu usmjerenih akata svijesti koji ga zapravo postavljaju na drugoj strani; na osnovu njih on vrijedi te je s obzirom na njih određen način njegova bivstvovanja. ${ }^{375}$

Husserlova fenomenološka redukcija jest zapravo prijelaz iz prirodnog $u$ transcendentalni stav kroz epoche koji predstavlja čistu mogućnost promatranja. ${ }^{376}$ To pak dalje znači da, prema Husserlu, smisao rada svakog onog koji se bavi fenomenologijom jest u

\footnotetext{
${ }^{370}$ Isto, str. 94.

${ }^{371}$ Isto, str. 94. Husserl pojmom »originalna samodatost« naziva neposrednu evidenciju u kojoj se stanje stvari spoznavatelju izravno pokazuje samo po sebi.

${ }^{372}$ Usp. METZGER A., Phänomenologie und Metaphysik, Neske, Pfullingen, 1966., str. 191.

${ }^{373}$ Usp. Isto, str. 96.

${ }^{374}$ Usp. Isto, str. 96.

${ }^{375}$ Isto, str. 97.

${ }^{376}$ Isto, str. 98.
} 
usmjeravanju na metodu fenomenološke redukcije. Kasnije tu tvrdnju nastavlja razvijati Eugen Fink kao posljednji Husserlov asistent. Fink se zalagao za promišljanje fenomenologije i osobitosti joj pripadne kojoj nastoji biti vjerna. ${ }^{377}$ Prva je oznaka fenomenološke metode istraživanje samih fenomena svijesti, a druga je oznaka ono što Eugen Fink naziva samonalaženje duha u svijetu. ${ }^{378}$ Možemo se složiti s izričajima da se „ovom metodom, duh, razarujući samotumačenja i samorazumijevanja kojima je do tada bio okupiran, dospijeva do svog univerzalnog vlastitog bića kao osnove apercepcije“. ${ }^{379}$ I treća karakteristika ove metode jest da se bit fenomenološke metode ne dohvaća indukcijom ni dedukcijom, već intuicijom. To znači da se metoda ne svodi samo na izvanjsko opažanje predmeta već na njihovu analizu, to jest pokušava dati odgovor na pitanje što su predmeti koje promatra uopće. Za Husserla je intuicija dvoznačan pojam, s jedne strane ona je empirijska intuicija s kojom spoznajemo sve pojedinačne predmete dok s druge strane postoji eidetska intuicija kojom se sagledavaju čiste biti. Za uočiti je kako Husserl pojmu intuicije ovdje daje specifično filozofsko tumačenje, onkraj svakodnevnog kojim se označava tek puki osjećaj naše procjene, poglavito s obzirom na situaciju i osobe.

Sve ovo do sada rečeno pokazuje kako je pitanje istine (u ontološko-spoznajnom smislu) posebno važno za fenomenologiju. Pojam evidencije pri tome se pokazuje presudnim i vrlo važnim, kako za Husserla samog, tako i za sve mislioce koji se bave fenomenologijom. Produbljivanje pitanja o istini i dalje o evidenciji daje na važnosti cjelokupnoj Husserlovoj misli i on ostaje posebno poznat (kao i općenito fenomenologija), a to je izričaj „Zu den Sachen selbst“ ili u prijevodu ,prema samim stvarima“. Zato će se u nastavku rada govoriti upravo o spomenutom Husserlovu izričaju.

\subsection{Husserl - „povratak prema samim stvarima“}

Kada se govori o Husserlovoj metodi fenomenologije, najčešće prvo što se pomisli jest njegov izraz ,prema samim stvarima“, čime se naznačuje važnost povratka prema onom što jest na način na koji jest. U procesu spoznaje dakle sudjeluju stvari po sebi. U tome smislu „fenomenološka metoda nastoji predmete kojima se bavi i koje istražuje dovesti do datosti u

\footnotetext{
${ }^{377}$ FINK E., Operative Begriffe in Husserls Phänomenologie, u: Nähe und Distanz, Alber, Freiburg - München, 1976., str. 196.

378 GEIGER M., Beiträge zur Phänomenologie des ästhetischen Genusses, u: Jahrbuch für Philosophie und phänomenologische Forschung, sv. 1, 1913., str. 567-684.

${ }^{379}$ FINK E., isto, str. 169. i UZELAC M., isto, str. 99.
} 
odgovarajuće formiranom iskustvu i da te datosti budu vjerno opisane““ ${ }^{380}$ Stvari o kojima je ovdje riječ jesu idealni predmeti. Okretanje stvarima podrazumijeva njihovo tematiziranje u njihovoj samodostatnosti u njihovom takoreći nuđenju spoznajnom subjektu, oslobođenim svega izvanjskog (predrasude, uvjerenja, kontekstualnost itd.). ${ }^{381}$ Usmjerenost pak stvarima, kako Husserl ističe, uzima u obzir znanstveno i umno suđenje o stvarima koje bivaju oslobođene od svakog mnijenja. ${ }^{382}$ Spomenuto znanstveno i umno suđenje o određenim stvarima koje se pritom promatraju odvija se uvijek u okviru smislene stvarnosti života kao takvog. Čovjek, naime, stvara fenomene i daje im smisao. Riječ je o fenomenološkoj redukciji koja zapravo znači otkloniti utjecaj vjerovanja o predmetu koji se promatra, ne oduzimajući bilo što stvari koja se promatra i time spoznaje. Ona omogućuje da se predmet jasnije odredi. Rezultat fenomenološke redukcije jest ,polje apsolutnih znanja izvan kojega ostaju svijet, Bog, objektivnost znanosti, višeznačnost matematike (koji i dalje bivaju prisutni, ali ne kao temelj već kao pojave)““. ${ }^{383}$ Eugen Fink za redukciju kaže kako je ona metodološki put unatrag kojim je moguće osigurati sigurno tlo za svako daljnje promišljanje o stvarima koje su predmet istraživanja. ${ }^{384}$ Fenomenološka redukcija zahtijeva provođenje nekih koraka, prvi od tih jest fenomenološko epoche. Taj se prvi korak vrši potpunim isključivanjem prostornovremenske egzistencije u svakom sudu, to jest stavljanjem u zagrade ključne teze prirodnog stava ili, još bolje, stavljanjem po strani svega što se naziva pretpostavkom. Sam Husserl polazi od sljedećeg uvida: „Ako se fenomenologija hoće shvatiti kao jedna izvorna znanost onda u njenu bit spada distanciranje od svih dogmatskih znanosti i pojmova, započinje isključivanjem prirodnog svijeta, zatim svih fizičkih i psihofizičkih predmetnosti kao i svih individualnih predmeta koji se konstituiraju u vrednujućem i praktičnom djelovanju svijesti“ “ ${ }^{385}$ Svi ovi doživljaji koji se isključuju unutar svijesti vode k tome da ostane čisto ja, odnosno čista svijest. To je svijest očišćena od svih vanjskih utjecaja, spremna za čisto neopterećeno mišljenje. Ovdje se upravo pokazuje bit fenomenološke redukcije u njezinoj najdubljoj osnovi: „ona je zapravo put kojim se dospijeva do čiste subjektivnosti uopée i njene svijesti“‘.386

\footnotetext{
${ }^{380}$ Isto, str. 100.

${ }^{381}$ Usp. Isto, str. 100.

382 Usp. HUSSERL E., Ideen zu einer reinen Phänomenologie und phänomenologischen Philosophie, M. Niemeyer, Tübingen, 1980., str. 35.

${ }^{383}$ UZELAC M., Fenomenologija, str. 105.

${ }^{384}$ Usp. Isto, str. 106.

385 Isto, str. 114-115.

386 Isto.
} 
Zaključimo - filozofska-znanstvena disciplina kakvu je utemeljio E. Husserl, transcendentalna fenomenologija, pretpostavljena je jednostavno kao »znanost o fenomenima«. Ovdje je, međutim, važno istaknuti da se ne radi tek o pukim fenomenima, to jest fenomenalnosti (pojavi) nečeg uopće, pogotovo ne pukim pričinima ili prividima $u$ svakodnevno smislu riječi te da bismo na osnovu toga izvjesnog „susretanja na sredini“ subjekta i predmeta dolazili do spoznaje, odnosno biti istog, već upravo znanost o samim stvarima i to na način kako su nam dane i kako se u svijetu pokazuju same sebi, oslobođene tako svega suvišnog u pogledu spoznaje. Stoga je i više nego jasno da prema (suvremenoj) fenomenologiji svijet »fenomena« dakle nije svijet pukih pojava, koje nužnošću i slučajnošću susreta nailaze, nego svijet stvari kako su nam one dane s obzirom na svoje temeljne uvjete postojanja - bit i bitak. Osim stvari, te jasno subjekta, Husserl u svojoj fenomenologiji polaže iznimnu važnost i na svijet kao takav, odnosno kao svojevrsno „događanje“ stvari. Zasigurno se svijet i stvari, vidljivo je to iz njihova predočenja, razlikuju u načinima svoje danosti koja svakako ostaje uvijek danost po sebi, fenomenologija upravo očituje njihovo jedinstvo i, dakako, istinu. Upravo se zbog toga jedinstva te upućenosti stvari na svijet, ali i obratno, sâm svijet pokazuje kao horizont horizonata ili, kako kaže kasni Husserl, kao doslovno »svijet života« (die Lebenswelt). Svijet života ovdje zadobiva na važnosti što se sama spoznaja odvija u kontekstu i, dakako, ovisnosti o raznolikosti načina danosti samih stvari, nadalje, od njihova zamjećivanja te predočivanja i sjećanja od strane subjekta preko komuniciranja i djelovanja. Konačno, sam svijet života očituje se za subjekta i njegovo spoznavanje stvari nezaobilaznim zbog, za fenomenologiju također nužnog, umnog opravdavanja i osmišljavanja raznovrsnih načina upravo tog samog »svijeta života ${ }^{387}$

Martin Heidegger, kao onaj koji je učio od Husserla, Husserlov »povratak prema samim stvarima« (Zu den Sachen selbst) zamjenjuje »povratkom stvari« (Zur Sache selbst) ističući pri tome da postoji samo jedna stvar, a to je svijet. ${ }^{388}$ Svijet kao pojam, nakon Husserla, i kao jedina tema fenomenologije i dimenzija otvorenosti posebno je istraživan, osim kod M. Heideggera, također kod E. Finka.

Kada se radi o odnosu Husserl - Welte, tada je potrebno reći kako se Husserlov utjecaj na Weltea da iščitati iz njegova poimanja intersubjektivnosti jer odnos na kojem Welte toliko inzistira ,ja“ - „ti“ možemo povezati s Husserlom i njegovom idejom da intencionalna relacija noesis-noema uključuje međusobno impliciranje svijesti (ja) i predmeta (svega izvan

\footnotetext{
${ }^{387}$ Usp. Fenomenologija. BROZOVIĆ D., KOVAČEC A., RAVLIĆ S., Hrvatska enciklopedija, mrežno izdanje. Pristupljeno 26. 10. 2020. https://www.enciklopedija.hr/natuknica.aspx?id=19238

${ }^{388}$ Usp. UZELAC M., Fenomenologija, str. 100.
} 
mene), a tu svakako pripada i odnos prema drugom. ${ }^{389}$ Husserl to naziva transcendentni bitak, a to je onaj koji implicira da prije mene postoji drugo izvan mene te nije smješten ni u meni, a ni u drugom, već u relaciji (intencionalnosti) koja omogućuje intersubjektivnost. Ključno je to da to drugo kod Husserla nije Bog (kao i kod Levinasa koji je pod njegovim utjecajem), odnosno ako bi i mogao biti Bog, sigurno ne može biti predmet iskustva, a time ni Lebenswelta (svijeta života) te ga se tako ne može razumijevati doživljajem ili vjerom jer su oboje u zagradama, odnosno potpadaju pod redukciju. Ni u kojoj fazi Husserlova opusa Bog ne može biti dio doživljenog svijeta, no intersubjektivnost i odnos svijesti (ja) spram svega izvan mene je zasigurno poslužilo Welteu za daljnju razradu njegove fenomenološke misli i odnosa ,ja“ spram „,i““ koji se prvotno odvija u susretu.

Sve do sada rečeno poslužiti će kao temelj daljnjem filozofiranju Bernharda Weltea u području fenomenologije i filozofije religije te ćemo u nastavku razraditi bitne stavke Welteove fenomenologije religije. Welteova filozofska misao naslanja se na prethodnike u fenomenologiji, posebice Husserla kao začetnika fenomenologije i fenomenološke metode, a zatim i Heideggera koji je B. Welteu bio učitelj i filozofski uzor.

\subsection{O pojmu religije u Weltea - pretpojam i shvaćanje religije kao odnosa čovjeka spram Boga}

Kako bi se ispravno razumjela filozofija religije, najprije treba - primjenjujući zasade fenomenološke metode - obratiti pozornost na pojam religije. Od starine se pod religijom shvaća čovjekov odnos prema Bogu ili onom božanskom kao nečem što se očituje u svijetu i što u bitnome utječe i mijenja svijet te, dakako, ljude u njemu. ${ }^{390}$

Što se tiče prvotnog pristupa religiji, možemo se, radi temeljnog uvida i pregleda na početku poslužiti prikazom N. Skledara koji (prikaz) ujedno može poslužiti i kao uvod u samu problematiku u proučavanju religije uopće: „Što se tiče problema mogućnosti i domašaja (a time i granica) umskog, racionalnog, kao i a-racionalnog, doživljajnog odnosa spram nadnaravnog bića, filozofija religije je (dakako, osim različitih odgovora na ontologijsko pitanje o ontičkom ili samo psihičkom njihovom realitetu) ponudila različite varijante rješenja tog problema. S obzirom na način i mogućnosti odnosa i spoznaje transcendentnog bića, u

\footnotetext{
${ }^{389}$ Usp. HUSSERL E., Kartezijanske meditacije II., Prilog fenomenologiji intersubjektivnosti, prev. Zenko F., Centar za kulturnu djelatnost Saveza socijalističke omladine, Zagreb, 1976., str. 77.

${ }^{390}$ WELTE B., Filozofija religije, str. 36.
} 
afirmativnoj ili niječnoj, teističkoj ili ateističkoj varijanti, ili poziciji između njih, u filozofiji religije možemo razlučiti nekoliko osnovnih pristupa: 1. prvi je racionalistički, koji relaciju spram nadnaravnog bića smješta strogo u sferu uma i svijesti (Platon, Aristotel, Hegel, Holbach, Feuerbach); 2. a-racionalistički (iracionalistički), koji tu relaciju tumači kao isključiv djelokrug osjećajnosti, doživljaja, vjerovanja (Plotin, Tertulijan, Schleiermacher, Kierkegaard); 3. kompromis između gornja dva pristupa, s prevalencijom jednog od njih (Klement, Origen, Abelard, Eriugena, Augustin, Anselmo, T. Akvinski); 4. agnostički, koji transcendentno drži nedokučivim i aporičnim za naš teorijski um, ali ne isključuje praktičkoetičku i psihološku dimenziju i reperkusiju tog bića (Piron, Kant). “391

Nakon spomenutih osnovnih pristupa kakvi su bili važeći unutar duge povijesti filozofije treba reći kako Welteov stajalište jest ono koje započinje svoj pristup religije, odnosno teologije kao svojevrsne racionalizacije vjere. ${ }^{392}$ Welte, na tragu kršćanskih velikana vjeruje u um, prilikom pristupa religiji, što istovremeno podrazumijeva, po njemu, opravdanost filozofskog pristupa. Također je odmah početku važno istaknuti da Welte ovaj put ne radikalizira, kao što će to posebno biti slučaj u pozitivističko-analitički pristupima, kojih je naš autor bio svjestan, već fenomenu religije prilazi s mnogih pripadajućih mu pozicija. U tom smislu i on prihvaća činjenicu da je religija ,takva cjelina čiji su izvori i dimenzije višestruki i međusobno isprepleteni. Osim što je socijalna činjenica, ona je i metafizička, psihička i moralna činjenica““. ${ }^{393}$ Kada se radi o razlici između filozofije i religije, spomenuti autor kojeg se ovdje dotičemo ističe kako je „razlika između filozofije i religije i u sadržaju, ne samo u formi. Filozofija, i kad joj je polazište (pretpostavka) teističko, pod pojmom Boga promišlja prvog nepokrenutog pokretala (upravo zato jer se ne radi o kršćanskom Bogu), mišljenje mišljenja (Aristotel), ideju dobra (Platon), Jedno (Plotin) itd., što su sve samo pojmovne apstrakcije u odnosu na osobnog ,živog Boga“ ili „Boga ljubavi““

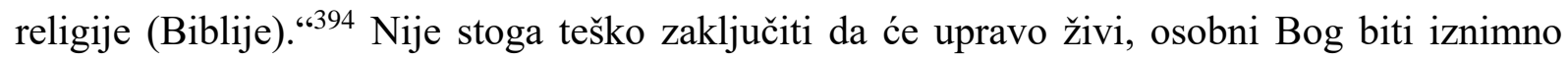
važna, štoviše središnja točka i samim time predmet Welteove filozofije i fenomenologije religije.

U suvremeno doba važnim se nameće ove pristupe i s njima pojmovlje pobliže odrediti i uzeti u obzir sve što unutar religije dolazi kao njoj usko pripadno. Prvotno je to odnos čovjeka prema Boga ili božanskom. Čime je taj odnos u bitnome određen (strahom,

\footnotetext{
${ }^{391}$ SKLEDAR N., Filozofija i religija - uz temu, u: FI, 5 (1989) 1, str. 4.

${ }^{392}$ Usp. Isto.

${ }^{393}$ Isto.

${ }^{394}$ Isto.
} 
divljenjem, ljubavlju, slobodom itd. te o čemu on, $\mathrm{s}$ obzirom na društvenu i svjetsku/svjetovnu konstelaciju, to jest vanjske okolnosti ovisi? Jesu li konačno one presudne u čovjekovu pristupu Bogu i njegovoj religioznosti općenito? Nadalje u pristupu religiji dolazi od presudne važnosti određivanje što je to čovjek? Naš pristup čovjeku, naime, uvelike određuje kako ćemo promatrati samu religiju iz jednostavnog razloga što je čovjek jedini izvršitelj religije. U tom smislu određivanje cjeline čovjeka uvelike ovisi način na koji ćemo zahvatiti, to jest shvatiti cjelinu onog fenomena, naime, religije u njegovu životu i svijetu općenito. Odnos čovjeka spram Boga nadalje vodi nas također $\mathrm{k}$ jednom određenom vidu ljudskog opstanka. Ljudski opstanak i način njegova izvršenja mjesto su na kojem se odnos gradi i gdje se on živi, naime, odnos koji nazivamo religijom. ${ }^{395}$ Samo se u religioznom odnosu ljudi ponašaju religiozno. U tom se odnosu ne smije smetnuti s uma da je također Bog onaj koji se prema čovjeku odnosi unutar njegova (čovjekova) odnosa prema Bogu. Ovdje se ne radi o pitanju prvenstva, već Welteova radikalnog razumijevanja čovjekova odnosa prema Bogu koji, kako je naznačeno, u sebi uključuje i Boga i njegovo takoreći odnošenje. Ovo je važno jer Welte suptilno ukazuje na razliku između boga grčke te posebno Aristotelove filozofije koji je čista „Theoria“, sebe-promatranje, odnosno Nepokrenuti pokretač te nema potrebu stvaranja nikakvog odnosa. Štoviše, upravo bi ta činjenica njegova „prilaženja“ i „silaska“, to jest filozofski očitovanja ljudima, bila znak njegove slabosti i gubitka božanstva. Ako se dakle Bog, prema Welteu, odnosi prema čovjeku, to ima svoje mjesto unutar čovjekova odnosa prema samom sebi, unutar čovjekova opstanka i njegova razumijevanja sama sebe. Stoga je potrebno govoriti o specifičnom obliku ljudskog opstanka. Čovjek reagira na Božje oslovljavanje tako da na njega odgovara. I jedno i drugo oslovljavanje, to jest Božje reagiranje čovjeku te čovjekov odgovor, zbiva se u obzorju ljudskog opstanka te je u tome smislu religija upravo jedan od načina ljudskog opstanka; to je onaj način po kojem čovjek zna i osjeća da je određen onom veličinom koja se zove Bog ili, neodređenije, ono božansko. ${ }^{396}$ Stoga u filozofiji religije, jer se radi i o čovjeku te religioznom načinu čovjekova opstojanja, treba govoriti o onom što je još više od čovjeka, što je (iako s njim povezano, ipak) drugo i drugačije od čovjeka, to jest ono božansko. ${ }^{397}$

\footnotetext{
395 WELTE B., Filozofija religije, str. 36.

${ }^{396}$ Isto, str. 37.

${ }^{397}$ Isto. Važno je ovdje uočiti kako Welte, koji je uostalom i katolički teolog, govor o Bogu ne pridržava samo teologiji već i filozofiji. Odnosno fenomenologiju religije ne želi sužavati tek na čovjekov odnos prema Bogu i sve što taj odnos uključuje već je proteže na samo biće Boga, propitujući ga u njegovim (filozofsko-teološkim) osnovama.
} 
Religiozni odnos ili religiozni način čovjekova opstanka, prema Welteu, razvija se u mnogim dimenzijama. Tu pripadaju dimenzije unutarnjosti, kao što su vjera ili meditacija, i dimenzije vanjskosti, kao što su kult ili naviještanje i drugo. Ponekad se u literaturi riječ religija rabi samo za ono izvanjsko, ono što se s Paulom Tillichom može nazvati kulturnim ruhom religije. ${ }^{398}$ Uz Paula Tillicha, Welte spominje još dva vrlo važna autora za shvaćanje teme religije i religijskog odnosa čovjeka prema Bogu. To su Dietrich Bonhoeffer i Karl Barth, prema kojima je religija, promatrano u cjelini, čovjekov pokušaj da vlastitim silama stekne Božju pravednost, naklonost i konačno milost. ${ }^{399}$ Welte je mišljenja kako sve ove stavove treba uzeti u obzir, no pri tome razumijevati kako je to sasvim jedan određeni način razumijevanja religije, kojoj se mora pristupiti s određenom dozom otvorenosti spram (drugih) fenomena koji joj pripadaju i koji ju znatno obilježavaju. Iz kritičke funkcije filozofije trebaju biti dobivena mjerila za kritičku obnovu religije. Ovdje se želi reći kako kritičku obnovu religije treba izvršiti i kršćanstvo iz njoj „drugačijim i u svojoj biti bližim mogućnostima“. To pak dalje znači da se religija uvijek zbiva kao ljudsko događanje i kao jedna od istaknutih formi ljudskog bivanja odnosno postojanja. ${ }^{400}$ Kada se radi o naglašavanoj fenomenalnosti religije, ona uvijek događa u čovjekovu obzorju, gdje se nalaze ljudi koji vjeruju, mole, okupljaju itd. Ovo izvršavanje pak religije od strane samih ljudi, potiče njih same, izvršioce, na dublje propitivanje razloga tog djelovanja, pri čemu se kod tog, svakodnevnog ne strogo filozofskog propitivanja javljaju mnoštvo drugih, s tim povezanih pitanja: svaki čovjek, naime koji želi shvatiti religiju, želi istovremeno razumjeti i samog sebe, vlastiti bitak u svijetu i sve ono što ga po tom pitanju zaokuplja u okviru izvršenja vlastite religije. Zanimljivim se pokazuje kako Welte takvo mišljenje koje se pita o bitku religije naziva specifično filozofijskim mišljenjem i gdje god je religija kao takva postavlja predmetom mišljenja, radi se upravo o filozofijskom mišljenju, specifično upravo za filozofiju religije. Gdje god se čovjek pita o bitku religije, u njegovo mišljenje nužno dolazi i pitanje o biti religije koja je zapravo slobodno ljudsko mišljenje koje pak ne samo dozvoljava nego i iziskuje, traži da pitanje o religiji i religijskom bude i kritički preispitano. To su, Welteovim riječima temeljne okolnosti koje daju da filozofija religije uvijek bude moguća.

\footnotetext{
${ }^{398}$ WELTE B., Filozofija religije, str. 38-39.; Usp. i TILLICH P., Religionsphilosophie, u: Gesammelte Werke, sv. 1, ur. Albrecht R., Stuttgart, 1959., str. 329-331. o temi Religija i kultura.

${ }^{399}$ Pobliže o toj temi u: SARTORY T., Braucht der Glaube 'Religion', u: HÖRGL C. i RAUH F., Grenzfragen des Glaubens. Theologische Grundfragen als Grenzprobleme, Zürich - Köln, 1967., str. 453-476.; HÖRGL C., RAUH F., Dualität und Einheit von Materie und Geist, u: HÖRGL C. i RAUH F., Grenzfragen des Glaubens. Theologische Grundfragen als Grenzprobleme, Zürich - Köln, 1967., str. 43-52.; HÖRGL C., RAUH F., Die Botschaft von Gott und unser Glaube, u: HÖRGL C. i RAUH F., Grenzfragen des Glaubens. Theologische Grundfragen als Grenzprobleme, Zürich - Köln, 1967., str. 477-511.

${ }^{400}$ Usp. WELTE B., Filozofija religije, str. 31.
} 
Prema Welteu, iznimno je važno religiju u današnje vrijeme razumijevati kao nešto što nije samo po sebi razumljivo i zato se potrebnim pokazuje i kritički reflektirati ponad pitanja koja su bitna za religiju kao takvu. Ta pitanja, vidjeli smo, prelaze uvijek u filozofijska pitanja (ljudsko razumijevanje (vlastita) bitka i slobodno ljudsko mišljenje uopće) te zato i jest riječ o filozofiji i fenomenologiji religije, o kojima će biti više riječi u nastavku rada.

\subsection{Welteova „filozofija“ $i$ fenomenologija religije - temeljna ishodišta $i$ izvodi}

Welteovo djelo Filozofija religije jedno je od krucijalnih djela freiburške fenomenologije o religiji. Od 1949. nadalje Welte je svoja predavanja o filozofiji religije, koja je svakako nadopunjavao i proširivao u tiskanom obliku, to jest u formi članaka i knjiga, označio temeljnim nazivom Fenomenologija religije. ${ }^{401}$ Shodno rečenom $\mathrm{u}$ prethodnom poglavlju dakle, s obzirom na Welteovu povezanost $\mathrm{s}$ E. Husserlom, odnosno fenomenologijom, nju naš filozof religije određuje na tragu njezina utemeljitelja (E. H.), kao „,iznašanje u pojavak svega onoga s čime se susrećemo“. ${ }^{402}$ Husserlov je utjecaj, već po samoj Welteovoj definiciji fenomenologije kao i njenoj važnosti za filozofiju religije, na Weltea i više nego očit. Welteova fenomenologija je obuhvatan način kako se gleda sve ono što je bitno za religiju. Husserlova fenomenologija prvenstveno obuhvaća ono bitno, eidetsko, no u govoru o intersubjektivnosti posebice nalazimo sličnosti s Welteovim odnosom „ja“-,ti““. Welteova fenomenologija u jednakoj mjeri obuhvaća i teoriju i praksu, um i djelovanje. U tom smislu upravo fenomenologija, prema freiburškom filozofu religije, biva posebno pogodna za opis biti religije. Od čega je stoga, prvo je pitanje, motivirano čovjekovo religiozno ponašanje te samim time i pojavak religije u stvarnosti? Welte pokazuje da je odgovor na ovo (prvotno) pitanje sadržano u odgovoru na pitanje o smislu. Čovjek kroz religiju odnosno njeno izvršenje, iznalazi puteve prema Bogu, sve u krajnjem cilju pronalaska odgovora na smisao vlastita, kao i života i stvarnosti općenito. Posebnost je u tomu što tim putevima hode ljudi kroz povijest, ali i mi u suvremenosti. U tim je pitanjima o smislu, kao i odgovoru na njih sadržano, uz religiju, i ono najbolje iz zapadne tradicije mišljenja filozofija, književnost, znanost te kultura općenito kao plod ljudskog duha u njegovoj sveukupnosti. Svakako je ono što nas ovdje s Welteom zanima religija i čovjekovo religiozno ponašanje $\mathrm{u}$ njegovom totalitetu. To nam ponašanje očituje, kako mi u svagdašnjem

\footnotetext{
${ }^{401}$ KIENZLER K., Filozofija religije, iz uvoda, prev. Kušar S., str. 11.

402 Isto.
} 
djelovanju - koje je svjesno odgovornosti - odgovaramo Tajni koja nas se bezuvjetno tiče. Welte nas time vodi pred kršćanskog osobnog Boga. A čovjekov odgovor biva dijaloški: vjera, molitva i kult. ${ }^{403}$

Važnim se uvijek i iznova nameće istaknuti da je Filozofija religije upravo filozofija. Ona je sposobna samu sebe razjasniti i odrediti. Čovjek filozofirajući sam misli. Točnije: filozofija se događa ondje gdje sam čovjek misli iz svoje vlastite sposobnosti, gdje misli iz svoje vlastite snage mišljenja i iz svojega vlastitog iskona. Filozofiranje je stoga izvrsna forma razvijanja izvornoga ljudskog mišljenja. ${ }^{404}$

Filozofijsko je mišljenje (pa tako i ono od filozofije religije) takvo da se nikada ne može dovršiti, ono nikada nije na kraju svoje stvari, niti je s njom ikada gotovo. Ona uvijek traga za novim putevima razumijevanja i shvaćanja stvarnosti koja joj prilazi u ovom slučaju religija. U tom smislu filozofija uzima za važnim tradiciju odnosno povijest mišljenja uopće pokazuje to posebno nepresušno vrelo tema u kojima se grčka filozofija rehabilitira i kao takva kontekstualizira u suvremenosti. U tom smislu filozofija otkriva stare (a zapravo nove) putove grčkih kao i svih drugih filozofa, posebno one koje označavamo kao klasike, kao one koji su uvijek iznova aktualni za suvremenost i koje treba uzeti u obzir prilikom razumijevanja onoga čime se ona (suvremenosti) bavi u ovom slučaju filozofijom (same) religije.

Mogućnosti mišljenja koje otvara bitak bića neograničene su. ${ }^{405}$ Kada razmatra ove mogućnosti i granice filozofije, Welte spominje jednog klasika filozofije - Boetija. Boetije donosi primjer koji se dojmio Weltea kada opisuje kako mu se u sužanjstvu (okovima zatvora) filozofija ukazala u liku ,žene tješiteljice“. Welte će reći kako susret sa ženom tješiteljicom jest nešto novo, plodonosno i beskrajno ohrabrujuće za svakog čovjeka. ${ }^{406}$ To je susret koji obogaćuje čovjeka koji se s njom susreće. Welte nadalje spominje Platonova Sokrata kao primjer koji je filozofiju želio razlikovati od mudrosti. Filozofija je za Platonova Sokrata „ljubeća težnja za ispunjenošću, ali ne i sama ispunjenost.“407 Aristotel ga je u tom mišljenju nasljedovao, kao što se može pročitati u Metafizici. ${ }^{408}$ Aristotel će zato reći: „No filozofija nije samo ljubav prema znanju kao najdubljoj spoznaji i mudrosti, niti se iscrpljuje

\footnotetext{
${ }^{403}$ Usp. KIENZLER K., Filozofija religije, str. 11. Ova tri načina izvršenja religije, svakako će se detaljnije razmotriti u nastavku ovog rada.

${ }^{404}$ Usp. WELTE B., Filozofija religije, str. 21.

405 Usp. Isto, str. 28.

${ }^{406}$ Usp. Isto.

${ }^{407}$ PLATON, Fedar u: Ijon, Gozba, Fedar, prev. Đurić M. N., BIGZ, Beograd, 1985., $278 \mathrm{~d}$.

${ }^{408}$ ARISTOTEL, Metafizika, prev. Gavela B. B., Kultura, Beograd, 1971., 982b, 28 i d.
} 
tek u svojoj teorijskoj funkciji. Ona je podjednako i praktična djelatnost, težnja prema najboljemu životu i volja čovjeka da u najvećoj mjeri ostvari svoju čovječnost. Za razliku pak od teorijske djelatnosti spoznaje, u kojoj sudjeluje samo razumski dio duše, u praktičnom životu sudjeluje i nerazumski dio, žudnja (ő $\rho \varepsilon \xi \varsigma$ ), bez koje bi volja ostala nemoćna i nikada ne bi prerasla u ćudoredno djelovanje. Tomu odgovara i osebujno znanje, razboritost ( $\varphi \rho o ́ v \eta \sigma \iota \varsigma)$, koje odlikuje nastojanje i izbjegavanje, vodi ga promišljaj i izbor odnoseći se na ono što još nije, naime na ono buduće i zato je ćudoredna činidba prospektivna. Ta je spoznaja svagda ovisna o konkretnoj situaciji te kao razboritost postiže istinu samo u ocrtu kako to nalaže narav ćudorednih stvari koje su nestalne i promjenljive“. 409

$\mathrm{Na}$ temelju Welteovih razmatranja o značenju i važnosti filozofije općenito, nadovezuje se njegovo promišljanje o filozofiji religije koje ide u smjeru kako je upravo filozofija religije ona koja traga za odgovorom na pitanje što je zapravo religija. ${ }^{410}$ Filozofija religije, tako, kao filozofijska poddisciplina, zauzima danas sve više prostora u humanistici odnosno onim znanostima koje se bave samom religijom, a koje možemo označiti jednostavnim pojmom, religijske znanosti.

Religija je uvijek vezana uza ljudsko mišljenje. Da bi filozofija religije mogla promišljati religiju, nužno je da joj ponajprije bude dana. Religija, stoga, prema Welteu, ,nije filozofija; već je ono drugo filozofije““ ${ }^{411}$ Religija se s filozofskim mišljenjem susreće kao ona koja je spram njega druga, ona koja mu stoji nasuprot pri čemu joj filozofsko mišljenje prethodi. Unatoč tomu valja upozoriti da se religija - koliko god živjela iz svojega vlastitog izvora i bila, u kršćansko-teološkom poimanju svojevrsni dar - zbiva kao ljudsko događanje i kao jedna forma ljudskog života i opstanka. ${ }^{412}$ Ona se događa u čovjekovu obzorju, jer uvijek su ljudi oni koji vjeruju, mole, okupljaju se na bogoslužje itd. Ako se pak čovjek služi svojim razumijevanjem sama sebe, on nužno pita i što je religija. I umujući ide tragom tog pitanja. A takvo mišljenje koje pita religiji upravo je filozofijsko mišljenje i iz toga je razloga filozofijsko mišljenje o religiji uvijek moguće ondje gdje je religija shvaćena, to jest umom zahvaćena, na koji god način. ${ }^{413}$

\footnotetext{
409 Aristotel, u: BROZOVIĆ D., KOVAČEC A., RAVLIĆ S., Hrvatska enciklopedija, mrežno izdanje. Pristupljeno 26. 10. 2020. Dostupno na: https://enciklopedija.hr/natuknica.aspx?ID=3834.

${ }^{410}$ Usp. WELTE B., Filozofija religije, str. 30.

${ }^{411}$ WELTE B., isto, str. 30. Ovo promišljanje Welte preuzima od autora H. Duméry-a, koje je pisao u svojemu djelu Phénoménologie et religion.

${ }_{412}$ WELTE B., Filozofija religije, str. 31.

${ }^{413}$ Isto, str. 33.
} 
Vjekoslav Bajsić kaže kako „religija nudi, a filozofija pokušava dati odgovor na pitanje ljudske egzistencije. Bitna je osobina čovjeka da pita, premda prečesto malo pita. Čim se nešto dovodi u pitanje, pretpostavlja se da pri tom postoji neki privid, to jest da se ne pokazuje sve, nego da je nešto skriveno. To što je najprije skriveno u prividu, u filozofiji jest aletheia, istina (što postaje neskriveno kad je spoznato), u religiji je to tajna, otajstvo, misterij. Stvarnost osjetilne pojavnosti nije takva ili samo takva kakvom se čini, nego nas sama neminovno upućuje dalje. Stoga i filozofija i religija transcendiraju neposrednu opažajnu danost, ali su načini različiti.“414

U vremenu u kojem religija, vjera i kršćanstvo gube staru samorazumljivost te njihov položaj biva u visokom stupnju kritičan, one ipak postoje, kao fenomen koji nije moguće zaobići. Welte se slaže s marksistom Gardavskijem koji kaže: Bog nije sasvim mrtav. ${ }^{415}$ Valja imati na umu, da se religija ne dade u potpunosti razumjeti u strogim filozofijskim, pogotovo logičkim formama. Jer, od velike je važnosti pokušati razmrsiti smisao religije, nasuprot nepravu i besmislu, koji su i s obzirom na čitavu stvarnost često na djelu. Tu se zapravo radi o, Welteovim riječima, ,pravu religije pred forumom uma“. 416

Welte je mišljenja kako filozofija može biti i opasna za religiju ako se u nju upliće na neprimjeren način, protiv smisla njezine stvari. Opasna neće biti ako pazi na svoju stvar kao na ono što joj je dano i trudi se tu stvar objasniti s obzirom na njezinu bit. ${ }^{417}$ Potreba je za razumijevanjem sama sebe i razumijevanja bitka u kojem religija zapravo živi, tada neće dolaziti do problema i krivog shvaćanja. Izvedena na pravi način, filozofijska rekonstrukcija religiji može biti samo od koristi. Kritička refleksija je bitna kako za razumijevanje religije od strane filozofije, tako i za razumijevanje religioznog života uopće. Za filozofijski pogled religija je unaprijed dana kao područje na koje se usmjeruje pogled mišljenja. ${ }^{418}$ Stoga, jedini ispravan način, prema Welteu, jest da „filozofija religije kao filozofija treba iz slobode i samostojnosti mišljenja razmišljati o stvari religije koje je mišljenju unaprijed dana““ ${ }^{419}$

Fenomenologija religije se uvijek bavi očitovanjem stvari - neke transcendentne zbilje. Ona je iznašanje u pojavak svega onoga s čime se susrećemo. Ponajprije se odnosi na stvarnost čije je obilježje transcendentalno, tajanstveno, sveto, nadnaravno, božansko, koje se očituje na razne načine, u raznim oblicima u svijetu i u ljudskoj svijesti. Iz toga razloga

\footnotetext{
${ }^{414}$ BAJSIĆ V., Neki problemi filozofskog prilaza religiji, u: $F I, 9$ (1989) 1, str. 6.

${ }^{415}$ GARDAVSKY V., Gott ist nicht ganz tot, München, 1968., str. 220-230.

${ }^{416}$ WELTE B., Filozofija religije, str. 34.

${ }^{417}$ Isto, str. 34.

${ }^{418}$ Isto, str. 35.

${ }^{419}$ Isto.
} 
Welteu su posebno bliski fenomeni Boga, božanskoga, svetoga, postojanja, nade, straha i u konačnici molitve kao odgovora spram onoga što nazivamo božansko. Stoga, za Weltea je fenomenologija (religije ${ }^{420}$ znanost o tajanstvenim i pomalo nedokučivim pojavama koje analizira i opisuje, ne ulazeći pritom u njihovu konačnu prosudbu. Upravo u tom smislu religija ne može biti dovršena filozofijom ili jasnije umskim zahvaćanjem, iz jednostavnog razloga jer je ona sveobuhvatnija.

Zadaća je fenomenologije, prema Welteu, nadalje, pokazati uzajamnost sa svim drugim znanostima, koje se bave religijom i religioznim životom, te, s tim u vezi, otkriti na koji način se one međusobno obogaćuju, neprestano se moderirajući u svom stajalištu i ne prekoračujući svoje granice i nadležnost s obzirom na zajednički predmet svim religioznim znanostima (religiozno ponašanje, tajanstveno, numinozno, božansko, Bog, Apsolut). ${ }^{421}$

U posljednje vrijeme vrlo je malo katoličkih filozofa, izuzimajući M. Blondela, koji su se izravno posvetili cjelovitom proučavanju odnosa između naravne i nadnaravne zbilje, bitne povezanosti ovih dviju različitih stvarnosti te čovjeka kao misaono-duhovnog bića u odnosu prema apsolutnom Biću - Bogu. Upravo i zbog toga, (ali ne samo toga), dobiva misao B. Weltea sve više na važnosti jer je ovaj filozof religije postavio zahtjev da se religija prouči s filozofskog stajališta ali i još više, da se vjersku predaju i živu tradiciju uvrsti i filozofska razmatranja. $^{422}$

Welteova fenomenologija religije postavlja odlučna pitanja, a u svakom je odlučnom pitanju on vidio mogućnost za uspostavljanje misaonih putova koji su pristupačni suvremenom čovjeku i koji mogu djelovati kao putokaz za promišljanja o vrhunaravnom, bio on vjernik ili ne. To je promišljanje, međutim, daleko od hladne kalkulacije, pri čemu bi se samog Boga postavljalo kao biće u nizu drugih podložno spoznavanju. S druge pak strane, Welte ne želi svojom fenomenologijom zapasti u „,neodređeni““ i „općeniti“ misticizam, pri čemu bi na svaki spoznajni problem o Bogu, odgovorio upravo načinom spomenute „tajanstvenosti“. Njegov je put fenomenologije religije, jednostavno rečeno, ljudski (ne u relativizirajućem smislu), no isto tako i božanski, svakako ne u dogmatskom smislu. Slijedom

\footnotetext{
${ }^{420}$ Ovdje se pomalo ustežemo od pojednostavljene i olake primjene izričaja „fenomenologija religije“ jer ona kao znanost proučava fenomen religije i religioznog uopće. Kod Weltea se pak radi o specifično filozofskom (ne usko fenomenološkom) pristupu religiji i stoga ovdje uzimamo samo pojam fenomenologija, pretpostavljajući pod time (Welteovu) filozofiju religije.

${ }^{421}$ Usp. LASIĆ H., Fenomenologija i filozofija religije, str. 9.

${ }^{422}$ Ovime se ne ukida Welteov stav (o nas donijet u prethodnim stranicama), da se religija, čovjekovo religiozno ponašanje te u konačnici Apsolutno, Bog, kao ono „drugotno“, „mistično“ itd..., ne može potpunosti zahvatiti odnosno rasvijetliti razumom. S druge pak strane, ove stvarnosti nisu ,izuzete“ stvarnosti odnosno one koje se, od strane uma, može samo „poštovati“ i puštati u postojanju, jer su i „ljudske“ bivaju podložne umskom propitivanju.
} 
rečenog, važnim se nameće iščitati u njegovoj fenomenologiji humani element koji pak također ne zapada u moraliziranje. Naime, po njegovu mišljenju čovjek svojim postupcima i djelima potvrđuje pitanje smisla svog postojanja, a svojim odgovornim ponašanjem zahtijeva za druge vlastiti hod prema bezuvjetnoj Tajni koja svojom objavom u svijetu ulazi u ljudski spoznajni obzor. Upravo tamo gdje ovaj osobni Bog određuje bitno ljudsko ponašanje, nastaje religija u punom smislu te riječi, tamo postoji religiozni čovjek kao izvršitelj religije koji, potaknut i pokrenut Božjom inicijativom (milošću), izražava svoju povezanost s Bogom kroz vjeru, molitvu i štovanje. ${ }^{423} \mathrm{U}$ nastavku treba vidjeti u kojem se kontekstu pojavljuje filozofija (fenomenologija) religije kroz povijesnu filozofsku situaciju i kontekst započevši od Wittgensteinova Traktata, filozofije znanosti i religije Karla Poppera, kritičkog racionalizma Hansa Alberta te, konačno, kritičke teorije i religije.

\subsection{Filozofija znanosti i religije u okviru Wittgensteinova Traktata}

Kroz prizmu filozofije i pripadnog joj svjetonazora Welte ukazuje na to kako se filozofijska situacija često oblikuje na dvije razine koje su neodvojiva jedna od druge. „Naime, jednom imamo posla s mjerodavnim filozofijskim mislima koje su bile iznesene u naše vrijeme. One mogu postati mjerodavne samo ako svoju mjerodavnost razviju za nekoga, u nekom širem području. I to je druga strana filozofijske situacije“. ${ }^{424}$

Welte se okreće nakon što se osvrnuo na postojanje kritičkog i racionalističkog pristupa religiji, ovoj prvoj spomenutoj grupaciji koja se bavila filozofijom znanosti, kroz primjere ranog Wittgensteina, Karla Poppera i Hansa Alberta te donosi prikaz takvog pogleda na svijet (Weltanschauung). Prema Wittgensteinu, treba strogo odjeljivati znanstvene od neznanstvenih izričaja. Slijedom navedenog, pojmovi poput Boga i religije pa čak i filozofije religije, polagano, dakle tijekom 20. stoljeća., bivaju potisnuti kao teme o kojima se, istina može nešto reći, međutim, za filozofiju (znanosti) one dolaze tek kao nešto naknadno. ${ }^{425}$ Wittgensteinovski rečeno, prvo dolaze logika i logička objašnjenja, a tek se potom razmatraju misli poput Boga i religije u njihovoj sveukupnosti. Činjenice su ono temeljno za Wittgensteina i znanost općenito.

\footnotetext{
${ }^{423}$ Welteovo teološko nasljeđe je ovdje je i više nego uočljivo. Međutim, ono nikako ne ništi filozofski moment svoje fenomenologije odosno filozofije religije. Naime, kada Welte ukazuje da u čovjekovu izvršenju religije, početnu inicijativu ima Bog, tada on ovdje, uključujući teološki aspekt milosti, raspravu ne želi okončati nego štoviše upozoriti da je za svako izvršenje religije u njegovu izvornom smislu, potreban jedan (božanski) Bog. ${ }^{424}$ WELTE B., Filozofija religije, str. 40-41.

${ }^{425}$ Usp. Isto, str. 39.
} 
Promotrimo li ponajprije ranog Wittgensteina i njegov Traktat, uvidjet ćemo kako je ovaj austrijsko-britanski filozof krenuo od jedne klasične formulacije filozofije znanosti, koju u ovom slučaju slijedimo. Wittgenstein je osnovne misli svoga Traktata kasnije nadopunio i proširio, a što se vidi u njegovim Filozofskim istraživanjima (Philosophischen Untersuchungen), koja je kod njega prvotno smatrana Filozofijom znanosti. ${ }^{426}$ Nećemo pretjerati ako kažemo da su Filozofska istraživanja jedno od najvažnijih djela koja su obilježila 20. stoljeće. Promotrimo li pozornije što je to Wittgenstein htio postići svojom raspravom, tada slijedeći dijelom Weltea, uviđamo sljedeće: Ponajprije nam ovaj Traktat donosi logička objašnjenja i misli te dalje nastavlja kako filozofija nije tek učenje, nego djelatnost, a filozofski rad se prvotno sastoji od različitih bilješki. ${ }^{427}$ Rezultat filozofije nisu tipično filozofske rečenice, nego postignute jasne tvrdnje. ${ }^{428}$

Prema Wittgensteinu, svijet biva određen činjenicama i time što sve jesu činjenice u svijetu, što bi pak dalje značilo, kako svijet počiva na činjenicama. Iz te pozicije, Wittgenstein se ne upušta previše u tumačenje Boga i religije, nego se zadržava na činjenicama, koje su po njemu, jedino razumljive i unikatne. Određenja kojima je činjenice moguće podvrgnuti u procjeni moraju biti sposobna za posebnu mjerljivost istih, ali su ipak konačna, kao i sam činjenice. $^{429}$

Welte dalje nastavlja, i kaže kako u svojim Predavanjima o etici iz 1929. godine, Wittgenstein posebno naglašava kako se sve etičke i religiozne izjave nalaze izvan jezika kao takvoga, a time i onog racionalnog po sebi. ${ }^{430}$ Welte ističe kako Wittgenstein u Traktatu kao i Predavanjima o etici iznosi svoje poštovanje prema religiji, međutim, o njoj previše ne govori jer ju ne smatra potrebnom za svoju filozofsku misao. U tom će smislu Wittgenstein ustvrditi: „Sumnja da su religija i filozofija religije besmislene čini se utemeljenom u osnovnom držanju te filozofije, premda mogućnost religije (ili kako Wittgenstein na navedenom mjestu kaže op. a.) «onog mističnog ostaje» otvorena.“431

Iz svega se navedenog dade zaključiti kako i spomenuta sumnja ima dublji smisao od tek i samo sumnje kao takve. Naime, ta sumnja navodi znanost da i dalje traga za istinom i da potraži ispravan trag koji će dovesti do istine filozofije religije.

\footnotetext{
${ }^{426}$ Usp. Isto, str. 39.

${ }^{427}$ Usp. WITTGENSTEIN L., Tractatus logico-philosophicus: Logisch-philosophische Abhandlung, Suhrkamp Verlag, Berlin, 1963., str. 7-83.

${ }^{428}$ Usp. Isto, str. 7-83.

${ }^{429}$ Usp. WELTE B., Filozofija religije, str. 40.

${ }^{430}$ Usp. Isto, str. 41.

${ }^{431}$ WITTGENSTEIN L., A lecture on Ethics, u: Philosophical Review, 74 (1965) 1, str. 3-13. i WELTE B., isto, str. 43.
} 


\subsection{Filozofija znanosti Karla Poppera, kritički racionalizam Hansa Alberta i Frankfurtska ,kritička teorija“}

Još jedan od autora kojeg Welte spominje u kontekstu promišljanja o modernoj egzaktnoj znanosti jest Karl Popper. Popper u svojem djelu Logika istraživanja ističe rast i napredovanje znanja kao predmet svoga promišljanja i istraživanja. ${ }^{432}$ Welte ističe kako Popper „,izričito kaže da izbor počiva na sklonosti“.433

Kao jedan od utjecajnijih filozofa 20. stoljeća, Popper je predstavnik kritičkog racionalizma ${ }^{434}$. On je smatrao kako temeljna osobina svih znanstvenih teorija jest upravo mogućnost da ona bude i opovrgljiva. To prvenstveno znači kako je određena teorija i rezultati koje ona daje postavljena tako da oni mogu biti podvrgnuti i testirati se kroz pozitivno iskustvo. Ako bi se ti rezultati pokazali kao netočni, u tom slučaju i pojedina teorija biva opovrgnuta, to jest netočna. Popper je smatrao kako se sve teorije koje ne ispunjavaju ove kriterije ne mogu više nazivati znanostima, nego tek pseudoznanostima. ${ }^{435}$ Zato je ovaj britanski filozof uveo princip opovrgljivosti kao kriterij pomoću kojeg se može razlikovati znanost od neznanosti. ${ }^{436}$ Znanstvena teorija je teorija koja je nekompatibilna s empirijskim promatranjem, a neznanstvena teorija, za Poppera jest ona, koja je u skladu sa svim promatranjima. ${ }^{437}$ Tvrdnja može na prvi pogled zbunjivati jer se Poppera uzima kao teoretičara znanosti koji snažno zastupa upravo znanstveni pristup, koji se pak uobičajeno veže upravo za ono empirijsko, činjenično. Odgovor leži u pojmu koji se rabi za Popperovu teoriju uopće - „kritički racionalizam“ kao i njemu pripadajućem načelu opovrgljivosti. O čemu se radi? Popper uzima načelo empirije vrlo obazrivo, te se suprotstavlja stajalištu da je ono, samo po sebi, znanstveni pristup to jest metoda. Pri tome donosi nadaleko poznati primjer s labudovima. Kako ćemo naime uzeti znanstveno relevantnom tvrdnju da su svi labudovi načelno bijele boje? Empirijska provjera ovdje malo pomaže, jer je nemoguće provjeriti sve labudove svijeta. Popper zaključuje, da sve dok ne „naiđe“ jedan crni labud,

\footnotetext{
${ }^{432}$ Usp. POPPER K., Logik der Forschung, Mohr Siebeck Verlag, Tübingen, 2005., str. 601.

${ }^{433}$ WELTE B., Filozofija religije, str. 44.

${ }^{434}$ Usp. HALDER A., Filozofijski rječnik, prev. Sesar A., Naklada Jurčić, Zagreb, 2002., str. 186-187.; kritički racionalizam - filozofska škola koja se posebno zanima za epistemologiju, sociologiju i politiku. Tim se pojmom često označuje i filozofija K.R. Poppera ako je suprotna logici utemeljenoj na klasičnom racionalizmu i empirizmu, koji odbacuju sve hipoteze koje se ne mogu argumentirati i iskustvom potvrditi. Naprotiv k.r. nastoji uočiti i ispitati pogreške koje su prisutne u svakoj teoriji, jer se samo tako može doći do istine. Pristalice k.r. smatraju da se do istine ne može doći dokazivanjem, nego samo preko otkrivanja pogrešaka. Uz K.R. Poppera glavni su predstavnici k.r. i filozofi tzv. "Frankfurtske škole" (T.W. Adorno, M. Horkheimer).

${ }^{435}$ Usp. WELTE B., Filozofija religije, str. 42-43.

${ }^{436}$ Usp. AFRIĆ V., Uvod, u: Revija za sociologiju, 34 (2003) 1-2, str. 5.

${ }^{437}$ Usp. Isto, str. 5.
} 
dakle onaj koji bi opovrgnuo navedenu tezu, možemo uzeti znanstveno utemeljenu pretpostavku da su labudovi (po sebi) bijele boje. Radi se o sljedećem: ne može se na temelju induktivnih sudova doći do općevažećeg načela. Moguća je samo dedukcija. Jer je temeljena na empiriji indukcija je varljiva. ${ }^{438}$

Prema Popperu, ključni je problem filozofije znanosti poteškoća razlikovanja između pojma znanosti i pojma neznanosti (logika, metafizika, psihoanaliza i Adlerova individualna psihologija itd...). ${ }^{439}$ Vjekoslav Afrić ističe kako se za Poppera „znanost, kao i sve druge ljudske aktivnosti, uglavnom sastoji od rješavanja problema“. ${ }^{440}$ Popper to upravo pokazuje zastupanjem teorije opovrgljivosti. Za Poppera je teorija znanstvena samo ako je i opovrgljiva. U tom smislu prema Popperu je „svaka istinska znanstvena teorija izricanje neke zabrane, u smislu da ona zabranjuje, po svojim implikacijama, da se dogode određeni događaji. Kao takva ona može biti testirana i opovrgnuta ali nikada logički potvrđena. “441 To bi pak dalje značilo da neka znanstvena teorija može biti i trenutno prihvaćena kao važeća sve dok se ne pronađe neka bolja teorija koja će biti potvrđena. Ono što je bitno za zamijetiti u Popperovu cjelokupnom proučavanju filozofije znanosti i znanstvenih teorija jest upravo to da smo teorijom opovrgavanja sposobni eliminirati krive teorije, i okrenuti se onim koje su ostale neopovrgnute. Zato Popper ističe ,važnost kritičkog duha u znanosti, duha koji je sama bit znanstvene racionalnosti. Kritički duh jest princip na osnovu kojeg među preostalim teorijama biramo one koje imaju najveću eksplanatornu snagu i predikativnost. ‘442

I u ovoj, kao i u prethodnoj teoriji Bog nije toliko bitan za tumačenje ovog čisto znanstvenog stava i stajališta. Popper Boga kao i time filozofiju religije ne uključuje u svoju teoriju jer oni nisu presudni za njegovu znanstvenu teoriju. Ostavlja ih više po strani kao puke metafizičke eksplikacije koje su potpuno izvan (njegova) kritičkog racionalizma kao i metode opovrgljivosti.

Još jedan od autora kojem se Welte kratko posvećuje jest Hans Albert odnosno njegovoj misli kritičkog racionalizma. ${ }^{43}$ Welte je mišljenja da kritički racionalizam ${ }^{444}$, kako

\footnotetext{
438 Popper, Karl Raimund, u: Hrvatska enciklopedija, mrežno izdanje. Pristupljeno 3.8.2021. Dostupno na: https://www.enciklopedija.hr/Natuknica.aspx?ID=49502

${ }^{439}$ Usp. AFRIĆ V., Isto, str. 5.

${ }^{440}$ Usp. Isto.

${ }^{441}$ Usp. Isto.

442 Isto, str. 6.

${ }^{443}$ Albert H., njemački filozof (Köln, 8. 2. 1921). Predavao na sveučilištu u Kölnu, od 1963. do umirovljenja 1989. redoviti profesor sociologije i teorije znanosti na Sveučilištu u Mannheimu. Najznačajniji predstavnik tzv. kritičkog racionalizma; sudionik u sporu oko pozitivizma u njemačkoj sociologiji (Th. W. Adorno, R. Dahrendorf, J. Habermas, K. Popper), u kojem se suprotstavio kritici pozitivizma i znanstvenog racionalizma. Glavna djela: Traktat o kritičkom umu (Traktat über kritischer Vernunft, 1968), Pledoaje za kritički
} 
ga Albert prikazuje jest onaj koji nadilazi neopozitivističku misao i suprotstavlja se empirizmu. Prema Welteu, upravo je Albert pokazao kako ne postoji niti jedno područje unutar ljudskog djelovanja, u kojem ne bismo trebali biti kritični. ${ }^{445}$

„To razmišljanje prije svega je poduprto argumentom tzv. Münchhausenove trileme, u kojoj je riječ o sljedećem: Ako se za sve rečenice zahtijeva utemeljenje, da bi postale nedvojbeno sigurne, na koncu preostaje samo izbor između beskonačnog regresa utemeljivanja, koji se praktički ne dade provesti, i kružnoga logičnog zaključivanja, koje je logički pogrešno, ili pak prekid postupka na nekoj određenoj točki i proizvoljno objašnjenje da je ta točka siguran temelj. “446 Ono što Albert želi na poseban način istaknuti, nastavljajući svakako Popperovim putem, jest to da je nemoguće induktivnom metodom, a to znači onom na koju se znanost iznimno oslanja, do znanstveno utemeljene teorije. Na temelju prikazanog, i više je nego očito da će pitanja i problemi vjere te pitanja koja se razmatraju u filozofiji religije, poput božanskog Boga, biti u potpunosti izvan dometa kritičkog racionalizma, kakvog je uostalom, u oslanjanju na Poppera zastupao Albert. Izvršenje religije, svakako će biti podložno proučavanju, poglavito u sociološkom smislu (H. Albert i slovi po vokaciji za sociologa) međutim, i o tome se u strogo znanstvenom pogledu ne mogu donijeti racionalnoznanstveni sudovi niti se, prema njemu, zapravo i trebaju. Svakako, i radi jasnoće, Albert će posebno podvrgnuti kritici pojam dogmatizma, jer upravo u dogmatizmu te već spomenutoj vjeri postoje obrasci koje kritički racionalizam radikalno dovodi u pitanje odnosno dvojbu. ${ }^{447}$ Albert ovdje ističe da je upravo je kritika jedna od najstarije nastalih tradicija (predsokratovci) te je stoga i ovo dodatni argument da je valja uzeti ozbiljno u obzir. Zanimljivost je da od kritičkog propitivanja nisu kod H. Alberta izuzete ni same znanosti to jest njihove (po općenitom uvjerenju) sigurne metode. Jednostavno govoreći, mi ne možemo sa sigurnošću doći do krajnjeg utemeljenja znanosti i znanstvenih teorija. To Albertovo uvjerenje koje se

racionalizam (Plädoyer für kritischen Rationalismus, 1971), Transcendentalne sanjarije (Transzendentale Träumereien, 1975), Kritika čistoga nauka o spoznaji (Kritik der reinen Erkenntnisslehre, 1987), Kritika čiste hermeneutike (Kritik der reinen Hermeneutik, 1994), Ideal slobode i problem društvenoga poretka (Das Ideal der Freiheit und das Problem der sozialen Ordnung, 1994), u: BROZOVIĆ D., KOVAČEC A., RAVLIĆ S., Hrvatska enciklopedija, mrežno izdanje. Pristupljeno 26. 10. 2020. Dostupno na: https://www.enciklopedija.hr/natuknica.aspx?id=1395

${ }^{444}$ Welte će, s obzirom na kritički racionalizam, reći sljedeće: „Kritički racionalizam nadilazi neopozitivizam utoliko što načelno smatra da su empirija i njoj pripadno oblikovanje teorija izložene mogućnosti pogreške, zbog čega su trajno podvrgnute kritici. U skladu s tim racionalizmom postoji samo trajno približavanje istini pomoću racionalne kritike stavova koji su predloženi kao istina.“ WELTE B., Filozofija religije, str. 45.

${ }^{445}$ Usp. WELTE B., Filozofija religije, str. 45.

${ }^{446}$ Isto, str. 46.

${ }^{447}$ Usp. Isto, str. 46. i također ALBERT H., Traktat über Krtisiche Vernunft, Mohr Siebeck, Tübingen, 1969. 
provlačilo kroz naš kratki prikaz njegove teorije, nadaleko je poznato pod pojmom antifundacionalizam.

Još jedna od teorija koje treba spomenuti jest ona kritička koja pripada Frankfurtskoj školi koju su posebno zastupali Theodor W. Adorno, Max Horkheimer i Jürgen Habermas. Ovdje se radi posebice o prihvaćanju moderne znanstvene svijesti. Welte će reći kako „kritička teorija ima praktičan cilj. Stalo joj je do prakse koja za cilj ima uspostavu umnog i zrelog čovječanstva““. ${ }^{448}$ Ova teorija se koristi metodom analize konkretnih društvenih i povijesnih odnosa u svijetu. To bi pak dalje značilo da analiza kojom se kritička teorija koristi treba donijeti odluku o tome što treba potvrditi, a što odbaciti iz svog razmišljanja kako bi ono bilo što točnije i jasnije. Kada se radi o religiji, kritička teorija koja slijedi K. Marxa religiju ne uzima u obzir. Skledar je mišljenja kako „Marxova pozicija i vizija nije, dakle, antiteistička, već ateistička, projekt povijest i društva bez Boga i koncept čovjeka kao slobodnog, stvaralačkog bića, kao autohtonog i autonomnog produktora iz prirode u povijest “. ${ }^{449}$ Skledar zaključuje kako ateizam nije u Marxovoj teoriji temeljno filozofijskoantropologijsko polazište već je on logička posljedica njegova humanizma.

Oni koji slijede M. Horkheimera religiju prihvaćaju kao nešto moguće i postojeće, no promatraju je isključivo kroz prizmu njezine društvene uloge, to jest je kao društveno relevantnu stvarnost koja sadrži „svoju“ korisnost za društvo. Prosvjetiteljski je aspekt ovdje i više nego uočljiv. Prosvjetiteljstvo, u vidu moderne, na kojem frankfurtska škola iznimno gradi, drži religiju dovršenom upravo kod njezina iscrpljivanja odnosno korisnosti za društvo. Prerečeno na frankfurtsku školu i M. Horkheimera, religija se u kontekstu društva uzima i (donekle) prihvaća relevantna institucija za društvenu situaciju svakog pojedinca koji s njome na ovaj ili ona način dolazi u doticaj.

Sve navedene teorije zasigurno imaju širok utjecaj na suvremeni svijet i svjetonazor. Dalekosežni je utjecaj svakako na društvene i humanističke znanosti kao i njihove discipline, te na sveučilišni kontekst obrazovanja mladih naraštaja i njihova razumijevanja pojmova „Znanost“ i „znanstveni pristup/metoda“. Welte zaključuje u tom smislu, kako filozofija religije treba s dužnim poštovanjem prihvatiti pa i ,učiti“ od svih ovih mišljenja, međutim, u konačnici ipak mora sama utvrditi svoj put i ponuditi odgovore na pitanja i problematiku kojom se bavi. Svakako, „rame uz rame“ postojećim teorijama. Nikako, dakle u inferiornom i podređenom stanju. I zaključno, Welteovim riječima „filozofija religije se ne može pozitivno

\footnotetext{
${ }^{448}$ WELTE B., Filozofija religije, str. 48.

${ }^{449}$ SKLEDAR N., Filozofija i religija - uz temu, u: FI, 5 (1989) 1, str. str. 4.
} 
oslanjati na filozofiju znanosti, no može se pozitivno odmaknuti od tih filozofija, tako da na vlastitim putovima iznese na vidjelo svoju vlastitu dimenziju““. ${ }^{450}$ Upravo je ovo put kojim filozofija religije treba kročiti prilikom objašnjavanja onoga Apsolutnog, koji se ne da označiti niti objasniti nikakvom znanstvenom filozofijom ili teorijom. Ovo je put koji vodi ka daljnjem Welteovu promišljanju o Bogu kao posljednjem temelju svega što jest. Iz toga razloga Welte dalje nastavlja svoje promišljanje o Bogu kao principu religije kako Ga naziva jer Bog je uvijek (izrečeno riječima Anselma Canterburyskog) veći od svega što se može zamisliti ili proučiti. Bog je veličina oko koje se religija konstituira i na temelj od kojeg sve polazi kada se radi o religijskom mišljenju i kršćanskoj religiji uopće. Upravo nas ta presudna „činjenica“ za religiju vodi k važnosti pitanja o Bogu kao principu i začetniku (svake te) posebno kršćanske religije.

\section{Bog kao princip religije u Bernharda Weltea}

U drugom poglavlju Welteova djela Filozofija religije riječ je o Bogu kao začetniku religije (Gott als Prinzip der Religion). ${ }^{451}$ To je istina koja se proteže kroz sve religije, kao i to da je upravo čovjek začetnik lažnih bogova i raznih oblika pseudoreligije. U svakoj stvarnoj to znači onoj religiji koja povrh „sebe“ priznaje i potvrđuje ,živog“ Boga, Bog je priznat kao stvaralac i vrhovni gospodar čovjekovih odnosa s njime. Uz Boga, tako nužno dolazimo do čovjeka, koji je jedini stvarni i uopće mogući izvršitelj religije. O tom odnosu u njegovoj najosnovnijoj formi, dakle onoj koja u obzir uzima i čovjeka i Boga, Welte će reći: „U religiji čovjek shvaća samoga sebe kao onoga koji je Bogom određen i koji se prema Bogu odnosi. Stoga je Bog ona veličina polazeći od koje se religija prvotno konstituira. To je pak moguće samo tako da je Bog na neki način čovjeku dan. No ta danost nije sama po sebi razumljiva, inače ne bi mogli biti da toliki ljudi našeg vremena ne vjeruju u Boga.“452

Čovjeku se pri tome odnosu često čini da je Bog odsutan ili da ga nema te Welte napominje kako ga je potrebno stalno iznova tražiti i tragati za Njim i konačno komunicirati s njime. U tom smislu, Welte dalje nastavlja i zaključuje s obzirom na božanskog (dakle od stvarnosti i čovjeka transcendirajućeg Boga) kako je upravo taj Bog tvorac svih čovjekovih religijskih odnosa i veza spram Boga. $U$ tom smislu pravi smisao svih čovjekovih napora $u$

\footnotetext{
${ }^{450}$ WELTE B., Filozofija religije, str. 47.

${ }^{451}$ Usp. Isto, str. 49.

${ }^{452}$ Isto, str. 53.
} 
kojima teži $\mathrm{k}$ Bogu jest upravo u tome da pronađe Boga koji već oduvijek pronalazi njega. Nikola Dogan smatra da je čovjek biće koje je uvijek u potrazi za smislom.

„Čovjek je sebi samome i drugima skriven. On je homo absconditus. Čovjek je jedinstveno biće koje se rađanjem ucjepljuje u postojeći svijet, ali on sebe još ne posjeduje, sebe nema““ ${ }^{453}$ N. Dogan ističe kako je čovjek često zarobljen u egzistencijalnoj bijedi svoga vlastita života i iz toga razloga uvijek traga za nečim većim, što u svijetu ne može naći i susresti. „Čini se da je čovjek vječni tražitelj, tražitelj, prije svega sebe i svojega bića, tražitelj sreće, zadovoljstva, mira i konačno prave i autohtone sreće. Ali, on je tražitelj i svog iskonskoga identiteta, za čije korijene u sebi ne nalazi potvrde. Čovjek je u trajnoj potrazi za Bogom, bez obzira na to što podrazumijevali pod riječju Bog!“454 Dogan ovdje nastoji ukazati na čovjekovu potrebu izvjesnog samonadilaženja egzistencije uopće.

Welteov Bog je, dakle, božanski Bog, a sveto je samo trag prema njemu. S. Kušar će reći „kako je sveto obitavalište Višnjega - i to tako da se ovaj u onom krije te ga ispred sebe šalje kao svoj trag. Welte dakle misli da Bog čeka i da se krije u onom ništa i sveto u bitku““ ${ }^{455}$ Božanski Bog se stoga ima razumjeti u Welteovoj misli kao „moguć i očekivani pojavak onog istog, svetog, koje je sa svoje strane najviša pojava bitka i onog ništa“. 456 Pojava bitka i onog ništa, koje spominje Kušar u kontekstu Welteova pristupa, može na prvi pogled izgledati proturječno, međutim ona to nije. Pod pojmom ništa ovdje se ne podrazumijeva (ontološka) negacija bića, upravo suprotno: ništa ovdje ima više stilski prizvuk Tajne, koja je ljudskom razumu i doživljaju u svojoj cijelosti nedokučiva, međutim, svojom se voljom čovjeku sama očituje.

Welte smatra kako u svim prilikama i neprilikama čovjek traga za Bogom, on je uvijek na putu ka Bogu i u toj vrsti traganja i živi svoj život. Upravo ovdje dolazi do problematike kako, ili još bolje, koji put ga može dovesti ka Bogu, bliže vrhovnom Stvoritelju koji je sve stvorio i sve daje. Iz tog razloga Welte navodi dva puta (prvi put promišlja tri temeljne činjenice ljudskog postojanja i drugi, koji govori o beskrajnoj Božjoj moći) koji nas vode ka Bogu i u Njegovu blizinu. Sama čovjekova sudbina ga već oduvijek iznutra nagoni da traži svoga stvoritelja. To je, prema Welteu, trajna zadaća svih ljudi. ${ }^{457}$

\footnotetext{
${ }^{453}$ DOGAN N., U potrazi za Bogom. Kršćanin u postmodernom vremenu, Teologija u Đakovu, Đakovo, 2003., str. 353.

${ }^{454}$ Isto, str. 355.

455 Isto, str. 209.

456 Isto.

${ }^{457}$ WELTE, Filozofija religije, str. 49-50.
} 


\subsection{Welteovi putevi prema Bogu - uvodno razmatranje}

Welte minuciozno razlaže i u isto vrijeme utemeljuje (svoja) dva puta k Bogu. Prvi od tih puteva jest onaj koji uzima u obzir tri temeljne činjenice koje obilježavaju ljudsko postojanje. Te činjenice su opstanak, ne-opstojanje ili ništa i pitanje o smislu i postulat smisla. ${ }^{458}$ Drugi put koji vodi k Bogu jest nacrt koji Welte donosi, a koji govori o beskrajnoj Božjoj moći iz koje svi proizlazimo. Postoji naime znanje koje je u svakoga čovjeka ucijepljeno, a to je da jednom nismo bili tu (na svijetu). Radi se, prema Welteu, o našem prošlom nepostojanju.

\subsection{Welteov prvi put prema Bogu}

Kada se radi o prvom spomenutom putu, prva činjenica koju treba promisliti jest upravo čovjekov opstanak. Welte kaže „mi smo tu, opstojimo, usred drugih ljudi, usred našeg društva, usred našeg svijeta““. ${ }^{459}$ Iz toga razloga Welte je spominjao na početku svojega promišljanja Husserla, kojeg sada nadopunjava i nekim temeljnim Descartesovim promišljanjima. Posebno će biti koristan Husserlov prvi stupanj, onaj fenomenologijske redukcije kojim se želi doći do sigurnog tla za sva daljnja promišljanja o čovjekovu opstanku. Welte prvo stavlja u zagrade sva moguća tumačenja našega opstanka, odnosno niti jedno od tumačenja ne želi uzeti kao obvezujuće već krenuti svojim putem. ${ }^{460}$ Naime, samim time što opstojimo u svijetu, pokazuju se neka iskustva koja svaki pojedinac na tom putu prolazi (djelovanje, aktivnost, patnja). Radi se o otvorenom prostoru ili mjestu naših iskustava.

„Ljudskom opstanku u svijetu pripada svjetloća ili otvorenost mnogim mogućim iskustvima, koja možemo steći na nama samima i na našem društvu i na našem svijetu“. ${ }^{461}$

Za zaključiti je da o opstanku u svijetu možemo govoriti jedino kroz prizmu iskustava koje prilikom našeg opstanka ili postojanja proživljavamo. Otvorenost iskustvima nikada nije ograničena jer su iskustva koja čovjek na tom putu opstanka prolazi uvijek otvorena i stoga Welte činjenicu opstojanja u svijetu naziva opstankom ili tu-bitkom. ${ }^{462}$ Ono se samo po sebi pokazuje i vrijedi za svakoga čovjeka, zato se i naziva opstankom.

\footnotetext{
${ }^{458}$ Usp. Isto, str. 54-68.

${ }^{459}$ Isto, str. 54.

${ }^{460}$ Usp. Isto, str. 55.

${ }^{461}$ Isto.

${ }^{462}$ Usp. Isto, str. 56.
} 
Druga činjenica koju Welte spominje prilikom tumačenja prvog puta ili nacrta koji vodi prema Bogu jest „ne-opstojanje ili ništa“. Tu drugu činjenicu izričemo sljedećim riječima „mi nismo uvijek bili tu, nismo uvijek opstojali i nećemo uvijek biti tu, nećemo uvijek opstojati““ ${ }^{463}$ Odmah se dade primijetiti kako je riječ o negativnim izričajima, ali kojima opet potvrđujemo svoje postojanje. Iz toga razloga je potrebno prvo objasniti što je to što Welte naziva „ništa“"? Nesumnjivo jest to da se u ovom izričaju skriva upravo ta činjenica da jednom više ne ćemo postojati. Ovaj izraz pogađa upravo naše trenutno opstojanje u svijetu u kojem jesmo. Ovaj izričaj je i donekle zagonetan i mogli bismo se pitati 'gdje ćemo to završiti nakon što nas jednom više ne bude'? Ovdje se bitnom pokazuje svjesnost čovjeka koji uviđa to da kao što trenutno jest i postoji tako ga jednom ne će biti. Welte ovdje daje primjer prirode koja za sebe ne zna, i ona neće biti jednom priroda za nas, ali za sebe će ostati priroda. Upravo to upućuje na činjenicu da jedino čovjek kao živo biće može shvatiti i razumijevati svoju kontigentnost to jest nenužnost u vidu da ga jednom neće biti. Uvjet tog uvida jest izvjesno samonadilaženje posredstvom kojeg čovjek između ostalog zahvaća svoju nedovršenost, krhkost, propadljivost, jednostavno ono „ništa“ za njega.

Iz toga razloga Welte kaže da ,utoliko smijemo reći da se ne-opstojanje, bivše i buduće, prvotno odnosi na ljudski opstanak u cjelini, pa odatle onda uključuje i sve što je svijet ili sve što može biti za čovjeka.“464 Iz toga se razloga (naše vlastito) ne-opstojanje u Weltea označava s nazivom „ništa“. Kada se, stoga radi o tom „ništa“, potrebno je prema Welteu, promisliti i čak doživjeti iskustvo toga „ništa“ koje svakako može biti motivirajuće u pogledu pitanja smisla te dalje drugog vida postojanja. I ovdje se opet radi o iskustvu koje je čovjeku dano, da doživi to „ništa“, to jest postane svjestan činjenice da ga jednom neće biti. Ovo „ništa“, Welteovim riječima treba razumijevati pozitivno, ne samo radi spomenutog poticaja, već iz tog razloga jer se nalazi unutar čovjekova opstojanja i ono je „ono drugo opstojanja i opstojanju pripadne pozitivnosti, kao nijekanje te pozitivnosti““. ${ }^{465}$

Pojam ništavila, o kojem se Welte ne usteže razmatrati, nadovezuje se na misaone dokaze za Božju opstojnost, koje on svodi na dva koncipirana puta koja upravo počivaju na iskustvenoj spoznaji postojanja izvjesnog ,ništa“, svakako prije i poslije ljudskog postojanja: Dasein (tubitak) i Nicht Dasein (ne-tubitak). ${ }^{466}$ Ovo „ništa“ nije bez ikakva sadržaja; „ništa“ je u stvari sam Bitak stvari, koje su po sebi nestalne i propadljive naravi, međutim, krajnjim je

\footnotetext{
463 Isto, str.56.

${ }^{464}$ Isto, str. 57.

465 Isto, str. 57.

${ }^{466}$ WELTE B., Filozofija religije, str. 78-94.
} 
naporom teže biti „to nešto“, očitujući istovremeno u sebi, uz propadljivost, trag onog stalnog i postojanog. Heideggerovim rječnikom rečeno, „ništa“ je skrivaonica Bitka, a Bitak je kućište bića. ${ }^{467}$ Tu-bivstvovanje i ne-tu-bivstvovanje upućuje na postojanje jedino nužnog Bića. Zato Welte, u prvom konceptu iskustvenog puta, pokušava shvatiti samu bit ovog „ništa“ na temelju iskustva postojanja nenužnog bića, na temelju ljudskog iskustva postojanja i iščezavanja u vremenu i prostoru: iskustvenost „ništa“ dvosmislenost „ništa“, odbijajuće „ništa“ beskonačnost i bezuvjetnost „ništa“ ${ }^{468}$ H. Lasić će reći „kako to „ništa“ nije stvar ili subjekt, „ništa“ kao Drugo tu-bivstvovanje, iz čega se može zaključiti da je „ništa“ zapravo „nešto“ beskonačno i bezuvjetno, da „ništa“, kako je od nas već dijelom ukazano, valja shvatiti kao pojavnost beskonačnog i bezuvjetnog, kao onostranost bivstvujućeg (Seienden), koje je ispred ljudskog postojanja te da mu treba kritički pristupiti pod filozofskim i teološkim vidikom". 469

Sva pitanja koja čovjek postavlja vezano uz ovo zagonetno ništavilo ispred sebe, a koje predstavlja budućnost, i iza sebe (prošlost) upućuju nas na zaključak da im on pristupa kao skrivaonici bitka u kojoj želi pronaći svrhu i temelj vlastitog života. Upravo se na prvome od navedenih puteva, javljaju pitanja o smislu života (Sinnfrage), kao i svega nestajanja u svijetu, a na drugome putu pitanja o temelju svega nastajanja (Grundfragen). ${ }^{470}$ Koliko god nam ovdje znanost može iznaći čak i zadovoljavajuće odgovore na pitanja koja sebi sami postavljamo, ipak je čovjek kao pojedinac onaj koji biva primoran, prema Welteu, izvršiti taj skok $^{471}$, transcendentni skok u beskonačnu misao koja svemu daje smisao, a koju predstavlja božanski Bog, koji sve utemeljuje a, koji, pritom, u konačnici sam nije utemeljen.

Welteovo bavljenje pitanjima „ništa“ , (čovjekova) „opstanka“, „smisla“, ukazuje da su ovo pitanja onkraj znanosti, pri čemu strogom racionalnom metodom ne dolazimo daleko. To pak nikako ne znači da su suprotna razumu već samo to da ga jednostavno nadilaze, upravo kao što ga nadilazi sam ljudski duh u teorijsko-spekulativnom smislu. Navedena se pitanja upravo stoga tiču specifično religijske sfere, već prema potrebi i načinu njihova postavljanja. Prema autoru N. Skledaru primjerice ,znanost je racionalna sfera duha koja nužno mora imati i empirijski odnos, dok je religijski odnos prema svom transcendentnom

\footnotetext{
${ }^{467}$ LASIĆ H., Fenomenologija i filozofija religije, str. 311-321.

${ }^{468}$ Isto, str. 311-321.

${ }^{469}$ LASIĆ H., isto, str. 311-321; WELTE, Filozofija religije, str. 78-94. Eckhartovski je koncept ovdje svakako uočljiv.

${ }^{470}$ Usp. WELTE B., Filozofija religije, str. 60.

${ }^{471}$ Utjecaj Kierkergaardove filozofije ovdje, dakako, ne može ostati nezapažen. Međutim, pojam skoka Welte će svakako proširiti na njemu vlastiti način. O Welteovu odnosu prema Kierkergaardu bavili smo se u jednom od prošlih naslova u dijelu rada koji govori o osobi.
} 
objektu u biti izvanrazumski ili nadrazumski odnos vjerovanja. Stoga se znanost ne može baviti transcendentnim objektom i mističkim sadržajem religije, te je u bitnom ne može ni oboriti, ni potvrditi“. 472

Treća činjenica koju smo samo uzgred spominjali, a koja ovdje zaslužuje veću pozornost te koju u tom smislu valja promisliti na putu spoznavanja Boga kao principa religije jest postulat smisla i pitanje o smislu. Welte kaže kako „temeljno držanje našeg živućeg opstojanja se počinje pokazivati u tomu da u svemu što poduzimamo i što kanimo poduzeti običavamo pitati o smislu. Pitanje o smislu prati cijeli naš život, bez obzira na to je li izričito formulirano ili samo neizričito življeno““. ${ }^{473}$ Ovo pitanje smisla uključuje u sebi živi interes cijelog našeg opstojanja. Samim time što djelujemo ovako ili onako, dakle redovito to jest uvijek u nekom smjeru, prema nekom cilju, označavamo to naše djelovanje kao ono koje treba nositi neki smisao, to jest imati smisao. Welte je mišljenja kako sama pretpostavka smisla vrijedi kao dinamika koja upravlja cjelokupnim našim postojanjem. Svi napori koje čovjek čini prilikom postizanja pojedinih ciljeva mogu se odrediti kao smisleni ili oni koji posjeduju neki smisao. Kada bi se čovjek odrekao činjenice da njegovo opstojanje ima smisao, tada bi se dogodilo ono na što A. Camus upozorava kada kaže da je samoubojstvo jedini uistinu filozofski problem. ${ }^{474}$ Welte spominje u ovom kontekstu i M. Blondela koji se u svojemu djelu naziva Djelovanje već na samome početku pita o smislu i ima li život kakav živimo uopće smisao. To je pitanje oko kojeg se vrti cjelokupni čovjekov život. Welte kaže kako „življeni pogled na smisao u cjelini i opravdani postulat smisla žive u temelju i korijenu ljudskog opstojanja“. ${ }^{475}$ To je Welteovim riječima i zov koji se pojavljuje ponad svakog čovjeka i tko mu se otvori i prihvati ga u svojoj slobodi može i spoznati njegovu istinu, a to je da život uistinu ima smisla.

Posljedica promišljanja ovih činjenica (opstanak, ne-opstojanje ili ništa i pitanje o smislu i postulat smisla) jest zaključak na koji Welte navodi, a to je da postoji ono beskonačno i bezuvjetno u kojem se nalazi smisao čitavog čovjekova postojanja. U tome (beskonačnom i bezuvjetnom) se skriva pozitivan vid onoga „ništa“. Beskonačno i bezuvjetno vode ka tome da se radi o Bogu, Bogu koji posjeduje moć koja je drugačija od svake vrste konačne moći ljudskog podrijetla. Tako na tragu govora o odnosu specifično racionalnoznanstvenog pristupa naspram religijsko-duhovnog, poglavito u pitanjima smisla, Welte ovaj

\footnotetext{
${ }^{472}$ SKLEDAR N., Filozofija i religija, u: FI, 5 (1989) 1, str. 268.

${ }^{473}$ WELTE B., Filozofija religije, str. 64.

${ }^{474}$ Usp. Isto, str. 67.

${ }^{475}$ Isto., str. 68.
} 
dio govora o smislu završava sljedećim riječima: „Tako vjera u beskonačnu i bezuvjetnu tajnovitu moć, koja na sve polaže pravo, svemu čuva smisao i o svemu odlučuje, može biti razumski utemeljena vjera“" ${ }^{476}$

Prema Welteu, nezaobilaznim se nameće razmotriti i kritike netom spomenutih puteva koji vode k spoznaji Boga: prva je teološka, a druga filozofska. Teološka kritika ovog puta po njemu se sastoji prvotno $u$ tome što ta ideja počiva na jednoj slici, koja biva prikazana ili potvrđena od strane ljudi te kao takva ipak uskraćuje Bogu njegovo božanstvo ili apsolut. ${ }^{477}$ Naša misao, u tom smislu, može otkriti samo ono što mi kao konačna bića možemo dosegnuti kroz svoju ograničenu spoznaju. Ideja, kao takva, nije utemeljena od ljudi niti od konačnosti već je bezuvjetna jer potječe od božanskog Apsoluta ${ }^{478}$; druga, filozofska kritika ovih puteva, polazi zapravo od socio-antropoloških danosti svakog pojedinca, pri čemu pojam idealizacije, najbolje odgovara onomu što smo s Welteom, svrstali pod pojam filozofske kritike. U tom se smislu također moglo čuti da je apsolutni Bog tek projekcija čovjekove subjektivnosti. Ludwig Feuerbach je bio jedan od onih koji su zastupali tu teoriju, naime, kako je Bog proizvod ljudskog mišljenja, imaginacije. Jednostavno, Bog je za Feuerbacha bio imaginarno ljudsko uporište. ${ }^{479}$ Karl Marx je također na Feuerbachovoj liniji tvrdeći kako je Bog opijum 'bezbožnika' te pripisujući Bogu atribute čovjek više govori o sebi nego li o Bogu. ${ }^{480}$ Sigmund Freud je pošao sličnim putem te je, kompleksno pitanje čovjekova puta k Bogu, dodatno opteretio svojim psihoanalitičkim domišljajima. ${ }^{481} \mathrm{O}$ upitnosti navedenih stavova, potrošeno je mnogo riječi i tinte. Međutim, valja ukazati i na to da su oni utjecali i još uvijek utječu na čitav sklop ljudskog stvaralaštva, počev od filozofije, preko psihologije i sociologije do, primjerice, književnosti. Mnogi se teoretičari ovih područja u vidu psihoanalitičkih, dekonstruktivističkih i sličnih strujanja, nadahnjuju upravo i spomenutim trojcem. Od kritičara pak, radikalnog feuerbachovsko-marxovskog polazišta, ovdje možemo spomenuti tek ime Paul Tillicha, kojim se, važno je to istaknuti, nadahnjivao i B. Welte, a koji je pak kritički zapitao: koliko su čvrsti psihološki i sociološki elementi, koji utječu na čovjekove stavove?, kada su i oni sami ograničeni te je vrlo teško sasvim usprotiviti im se kao i osloboditi ih se! (82 $^{4}$ No ono što je sigurno nemoguće, neovisno o bilo kojem kontekstu, uvjetovanosti pa i vjeri to

\footnotetext{
${ }^{476}$ WELTE B., Filozofija religije, str. 71.

${ }^{477}$ Usp. Isto, str. 73.

${ }^{478}$ Usp. Isto, str. 73.-74.

${ }^{479}$ FEUERBACH L., Das Wesen Christentums: Vollständige Ausgabe mit Anhang und Fußnoten, Holzinger, Berlin, 2016., str. 354.

${ }^{480}$ MARX K., Kapital, BIGZ, Beograd, 1979., str. 1595.

${ }^{481}$ Usp. WELTE B., Filozofija religije, str. 74.-75.

482 TILLICH P., Morality\&Beyond, Westminster John Knox Press, Kentucky, 1963., str. 104.
} 
jest religiji, jest osloboditi se bezuvjetnog karaktera moralnog imperativa. Čovjek može donekle zanemariti svoju dužnost spram dobra kao takvog, a zatim i drugoga, međutim, nikada se ne može do kraja osloboditi i napustiti moralni imperativ i samim time ga ignorirati. $^{483}$

S obzirom na netom rečeno, te kao zaključno promišljanje, možemo ustvrditi: moralni je aspekt, onkraj svakog moraliziranja, te suvišnog prožimanja vjere moralom, Welteu od iznimne važnosti. Istina, mjesto zakona i dužnosti, on radije govori o svijesti odgovornosti i savjesti. Potonje upravo očituje novost II. Vat. Koncila i s njim personalističko i kristovski utemeljenog morala. Spomenute odgovornost i savjest su upravo most, koji povezuje njegovu filozofiju religije s moralnošću kao takvom, pri čemu, spomenuti pojmovi odgovornosti i savjesti, kod Weltea nikako nisu lišeni, (kantovski govoreći), obveze i norme. Upravo suprotno: čovjek prema njemu i stvarno podliježe i normama, poglavito moralnim pri čemu to nije nikakav negativni vid podvrgnutosti koji bi ništio slobodu, već upravo suprotno, potvrda slobode, kako je to uostalom i Kant nekoć ukazao. U svakom trenutku, kako i sam Welte ističe, moramo biti svjesni moralnog imperativa koji je u nas duboko utkan, pa makar ga i zanemarili, jer on uvijek, na ovaj ili ona način izlazi na vidjelo. U tom se smislu nameće kao potreba živjeti u skladu s istim, a kako bismo ostvarili puninu življenja, kako moralnog tako i religioznog, jer se u konačnici religija jednim svojim dijelom izvršava i u moralu.

\subsection{Welteov drugi put uzdizanja k Bogu}

Prema Welteu, postoji i drugi put koji vodi ka Bogu. Taj put se pokazuje kao beskonačna moć koja je Bogu pripadna. Spomenuti otvoreni prostor iskustava u kojem se ostvarujemo vodi k tome da bivamo svjesni samih sebe, svojih ostvarenja, iskustava koja kroz život stječemo. Jednostavno smo svjesni činjenice kako jednom nismo bili tu i kako jednom to nećemo biti.

Na ovom se mjestu radi, Welteovim riječima, o „ništa“ koje dolazi iza nas. Radi se o našem prošlom nepostojanju i ne radi se o čisto fizikalnim i biološkim pretpostavkama, nego svjesnosti da naše ,ja sam tu“, „opstojim“ - nije postojalo prije no što smo se rodili. Welte nas tako upućuje još jednom na otvoreni prostor iskustava koje doživljavamo od trenutka kada smo se rodili. Pritom postajemo svjesni samih sebe i svojih doživljaja, spoznaja i

${ }^{483}$ Usp. WELTE B., Filozofija religije, str. 75. 
iskustava pri čemu možemo reći da smo to nešto (pro)živjeli čime pak konačno možemo potvrditi svoje opstojanje u ovom svijetu. Pokušavajući odgovoriti na pitanje zašto uopće jesmo, te već spomenuto „zašto uopće jest nešto, a ne ništa“?, čovjek razumijeva kako odgovor na to pitanje može pružiti jedino nešto vječno, bezuvjetno i posljednji temelj svega koji nazivamo „Tajnom“. Znanost može ponuditi odgovore, reći će Welte, no znanosti nikada nisu dovoljno zadovoljne odgovorom koji je predočen i uvijek žele saznati više, unaprijediti svoja znanja i otkriveno, međutim, to sve mogu u okvirima koji su im zadani. Iz toga razloga se čovjek po pitanju pristupa k Bogu ne može pouzdati u znanstvena otkrića. Zato i jest riječ o dubokom pouzdanju i otkrivanju Tajne koju nazivamo bezuvjetnom i beskonačnom - Boga.

Naš će filozof religije ova promišljanja nastaviti te će reći „sada imamo razlog za vjerovanje u bezgraničnu moć, moć koja nosi, odlučuje i čuva bitak sveg bića i s tog gledišta dodirujemo veliku Tajnu, koja se krije i ujedno otkriva u beskrajnom prostoru onkraj sveg bića, prostoru koji imenujemo sa ništa.“484 Onkraj svakoga nešto pojavljuje se Tajna koja nosi i odlučuje sav bitak, ono skriveno „zašto“, skrovito podrijetlo, bezuvjetni temelj. On se najavljuje u bezuvjetnoj odlučenosti bitka, onda kad tu odlučenost promatramo u svjetlu pitanja zašto uopće jest nešto, a ne ništa. Stoga Welte kaže kako imamo sve razloge vjerovati u „bezdano beskonačan temelj.“485 Bog kao bezuvjetni temelj nalazi se uvijek onkraj svega konačnog, pri čemu to konačno sam utemeljuje. U tom je smislu upravo Welteov Bog uvijek božanski Bog i on je bezdani temelj svega i u tom kontekstu biva nazvan ,zbiljom svekolike zbilje“. 486

Postoji neosporno i vrlo banalno znanje kako nismo oduvijek bili ovdje. Po Welteu, to je naša prošlost nepostojanja. Potonjom kovanicom, naš se autor, „blago i s poštovanjem“ nastoji približiti ateizmu, pokušavajući proniknuti u njegove teorijske osnove. Prošlost ne postojanja, ovdje Welte ne koristi za označavanje onog što dolazi nasuprot svemoćnog bića Boga, a prije stvaranja svega, već jednostavnu činjenicu našeg ne-postojanja, prije nego li smo zadobili bitak u pogledu onog ljudskog. ${ }^{487}$ Bitak pak zadobivamo u okružju drugog, sveopćeg bitka postojanja. To je svakako u prvom redu iskustveni prostor. Ovaj iskustveni prostor promatramo stalno u odnosu na sebe same (to što sam bio i što jesam stalno iznova formira moje iskustvo) i traje u odnosu na životnu djelatnost. To je nešto što nikada nije sasvim novo u odnosu na kompletno nepostojanje iza njega (iskustva), a reflektira se u

\footnotetext{
${ }^{484}$ WELTE B., Filozofija religije, str. 92.

${ }^{485}$ Isto.

${ }^{486}$ Isto, str. 94.

${ }^{487}$ Usp. Isto, str. 76.
} 
svakom pojedinačnom ljudskom postojanju. ${ }^{488}$ Iskustvo (vlastita) postojanja je najdublje i najprisnije iskustvo kojeg uopće imamo. Najprisnije, međutim, ne i samo po sebi razumljivo jer je, kako smo istaknuli, bilo vremena kad nas nije bilo. Kada je, s obzirom na naše vlastito ali i na postojanje uopće na djelu bilo upravo ništavilo.

Treba reći kako putevi koje Welte donosi nisu neka dva nova puta $\mathrm{k}$ Bogu, ali on ih na sebi svojstven način obogaćuje i prikazuje. Ta dva puta, o kojima je riječ, imaju svoj temelj u trećem putu (tertia via) sv. Tome Akvinskoga odnosno u njegovoj Summi Theologie i u tzv. ontološkom dokazu svetoga A. Canterburyjskog ${ }^{489}$, to jest u njegovom Proslogionu. ${ }^{490} \mathrm{U}$ preuzimanju ovih puteva, Welte ističe kako se oni nadopunjuju, iako ih u ovom smislu prvotno promatra na logički način, te ih na osnovu toga (logičke susljednosti i međusobne neproturječnosti sic!) međusobno i povezuje. U toj cjelovitosti to jest međusobnoj upućenosti jedan na drugoga, oni za njega (Weltea) daju potpun prikaz puteva koji prema njemačkom filozofu također vode $\mathrm{k}$ Bogu. Ti tajnoviti putevi, kako ih sam Welte označava, jesu, prije svega, bliski putevi koji vode do osobnog Boga koji se uvijek slobodno javlja, ali i uskraćuje kroz povijest, u mnoštvu raznih likova i znakova.

S obzirom na navedene, poglavito dva temeljna puta, S. Kušar će reći: „Oba puta koja je Welte trasirao dovode mišljenje pred apsolutnu Tajnu koja jamči smisao i temelj. Njezina beskonačnost i bezuvjetnost pokazuje se u fenomenalnosti onoga „ništa“ čija se dvoznačnost mogla odlučiti u pozitivnom smislu na temelju razumnih razloga. Apsolutnu tajnu se naziva ono božansko i naziva ju se Bogom. Božanski Bog u čovjeku izaziva religiozno ponašanje. Razliku između dva puta prema Bogu Welte naziva fenomenološkom razlikom. Heidegger smatra kako je pravo filozofsko ime za Boga „causa sui“ - uzrok samog sebe, a Welte ga u tome slijedi. Pred tim Bogom filozofa čovjek ne može ni moliti ni žrtvovati. Pred „,causom sui“ čovjek ne može pasti na koljena niti može pred tim Bogom muzicirati i plesati. “491 Iz tog razloga, s Welteom, za zaključiti da je najsmisleniji put čovjeka vjernika do Boga onaj u objavi. Iz ovog se vidi Welteov fenomenologijski argument koji on iznosi na vidjelo a to je

\footnotetext{
${ }^{488}$ Usp. Isto, str. 76.

489 Anselmo donosi svoj ontološki argument u djelu Proslogion. On Boga opisuje kao nešto najveće nama spoznatljivo - Bog je vrhunac sve naše spoznaje, On je vrhovno dobro koje ne ovisi ni o čemu, ali od Njega ovisi svačije postojanje i dobrobit. Anselmo je htio bezumnika, također podučiti kako je Bog vrhunac svih naših zamisli. U kritici Anselmova argumenta najčešće se prigovara da je čovjeku dao preveliku ulogu u dokazivanju Božje opstojnosti, on je taj koji Boga na neki način posjeduje u svome umu, što (kritika) nije bez osnove. Apriorni dokaz Božje opstojnosti tomu upravo i naginje i u tom bi smislu navedenu kritičku opasku valjalo uzeti ozbiljno u obzir, u: BROZOVIĆ D., KOVAČEC A., RAVLIĆ S., Hrvatska enciklopedija, mrežno izdanje. Pristupljeno 1.12.2020. Dostupno na: https://www.enciklopedija.hr/natuknica.aspx?id=2908 ${ }^{490}$ WELTE B., Filozofija religije, str. 96-110.

${ }^{491}$ KUŠAR S., Spoznaja Boga u filozofiji religije. B. Welte i božanski Bog, Biblioteka Filozofska istraživanja, Zagreb, 1996., str. 253-254.
} 
dosljednost fenomenološkom putu, upravo jer samu Objavu, u osnovi - kroz Riječ, smatra načinom Božjeg pojavka, očitovanja, odnosno fenomena u povijesti. Iako je Bog često onaj koji je nedohvatljiv i izmiče čovjekovu potpunom razumijevanju ipak kao apsolutna tajna uvijek se pokazuje kao posvemašnja transcendentnost vječnoga Ti. ${ }^{492}$ Iako se može činiti da je Bog čovjeku otuđen, ipak ga čovjek može zazvati i tako iskusiti njegovu bliskost u vlastitom životu. Tu dimenziju svojevrsne bliskosti koja upravo u molitvi kao istinskom izvršavanju religije biva očitovana, te koja, što je iznimno važno, izmiče svakom vidu konzumacije, to jest želje za posjedovanjem i ovladavanjem, S. Kušar izriče vrlo dojmljivim riječima na sljedeći način: „Kada je tajna zazvana, ona počinje za čovjeka biti religioznom veličinom. Religija naime započinje s onim „Ti“ molitve koje je u molitvenom zazivu izgovoreno, a molitva je pritom istodobno prožeta sviješću da dodiruje ono nedodirljivo i zazivajući oslovljava ono neizrecivo“. 493

$\mathrm{Na}$ putu Welteovog poimanja božanskog, osobnog Boga pojavljuje se kao izvor nadahnuća Meister Eckhart koji je našem filozofu iz Freiburga posebno zanimljiv sa svojim mističnim iskustvom „tamnog svjetla božanstva“ te će iz toga razloga u nastavku rada biti više riječi upravo o odnosu Meister Eckhart - Bernhard Welte i poimanju Boga i božanske osobe.

\section{Važnost metafizičkih promišljanja Meister Eckahrta za fenomenologiju religije Bernharda Weltea}

Svojevrsnu filozofsku inspiraciju u pitanjima Boga, osobe, njenoj vrijednosti i duhovnosti, te poglavito njezina odnosa prema toj beskrajnoj Tajni jest njemački srednjovjekovni teolog i mistik Meister Eckahrt. ${ }^{494} \mathrm{Na}$ više mjesta ističe Bernhard Welte svoju privrženost dubokoj, te do kraja svakako neshvaćenoj misli Meister Eckharta. 495

\footnotetext{
${ }^{492}$ Usp. Isto, str. 254.

493 Isto, str. 254.

${ }^{494}$ Meister Eckhart (1260.-1327.) bio je učeni njemački teolog, vodeći mislilac njemačkog misticizma. Za njega možemo reći da je vodeća ličnost dominikanskog reda u Njemačkoj, učeni teolog, no ipak i jedna od najkontroverznijih mislitelja njemačkog misticizma. Neke od najvažnijih karakteristika njegove mistike su: mistika neimenovanoga Boga te odnos Boga i čovjeka. Njegova mistika je bila potpuno usmjerena na nutarnjost jer se Boga traži i doživljava u nutrini, a ne u izvanjskome svijetu, u: BROZOVIĆ D., KOVAČEC A., RAVLIĆ S., Hrvatska enciklopedija, mrežno izdanje. Pristupljeno 28. 9. 2020. Dostupno na: https://www.enciklopedija.hr/natuknica.aspx?id=17027

${ }^{495}$ Možda najintenzivnija i najdetaljnije vidljiva privrženost Bernharda Weltea prema misli Meister Eckharta, vidljiva je u njegovoj monografiji iz 1979. godine Meister Eckhart, Gedanken zu seinen Gedanken.
} 
Djelo Markusa Endersa ${ }^{496}$ o Meister Eckhartu, govori o tome kako je Welteu, prema njegovu vlastitu priznanju, Eckhart izvor nadahnuća za promišljanja o mističnoj duhovnosti kao i filozofiju religije općenito. Prema Welteu, Eckhart je iznimno aktualna mislilac za suvremenost. Eckhartu Welte posvjećuje više svojih djela. ${ }^{497}$ Posebno zanimljiv za našeg filozofa religije je Eckhartov opis mističnog iskustva ljudi u »tamnom svjetlu božanstva«. Misli se, dakako, na Eckhartov pojam »dunkle Licht der Gottheit«. Njemački mistik ovim pojmom želi ukazati na potrebu i važnost radikalnog okretanja to jest promjene u ljudima, napose načina na koji se ophode prema onome koga označuju božanstvom, te u konačnici potrebu promjene uvriježenog, samo po sebi razumljivog, odnosa prema Bogu. Meister Eckhart svoja razmišljanja o Bogu, čovjeku i svijetu donosi prvenstveno kroz svoje propovijedi na jednostavnom njemačkom jeziku, koje su bile upućene običnom puku. Bernhard Welte je bio mišljenja da je upravo to način na koji je moguće promijeniti onoga tko razmišlja da uđe u novu dimenziju svoga bivstvovanja, u kojoj će na poseban način doživjeti totalitet Boga, svijeta i sama sebe. ${ }^{498}$ Ključan pojam, prema Welteu, koji karakterizira i opisuje takvu vrstu metafizike i na njoj zasnovanoga religioznog doživljaja, jest upravo pojam odvojenosti (Abgeschiedenheit). ${ }^{499}$ Kada govori o izrazu odvojenosti, Eckhart tim izrazom ne misli na opstojnost izvan svijeta, nego na egzistenciju u svijetu i za svijet, međutim slobodnu od svijeta. ${ }^{500}$ To pak dalje znači, da upravo Odvojenost omogućuje na autentični odnos sa svijetom, koji ujedno predstavlja istinsku povezanost sa svijetom: u to smislu ona ne znači biti izvan svijeta, nego ostati u njemu, ali ne biti njegov rob, ne biti vezan za svijet i događaje u njemu. ${ }^{501}$ Upravo je to smisao u kojem često Eckhart govori o egzistiranju u »tamnom svjetlu božanstva«. Ono što je bitno prilikom ovakvog načina egzistiranja jest uzimanje u obzir metafizičkih svojstava, Bogu pripadnih, međutim, te pojmovne apstrakcije u daljnjim promišljanjima postupno blijede i nestaju, te se rasplinjuju, u »tamnom svjetlu božanstva«. 502

${ }^{496}$ ENDERS M., Meister Eckhart und Bernhard Welte. Meister Eckhart als Inspirationsquelle für Bernhard Welte und für die Gegenwart, LIT Verlag, Berlin, 2015., str. 142.

${ }^{497}$ WELTE B., Meister Eckhart - Gedanken zu seinen Gedanken, Herder, Freiburg, 1992., str. 268.; te također djelo u koje je osim Eckharta pisao o drugim velikanima povijesti filozofije; WELTE B., Gesammelte Schriften II/1: Denken in Begegnung mit den Denkern I: Meister Eckhart - Thomas von Aquin - Bonaventura, Herder, Freiburg, 2007., str. 368.

${ }^{498}$ Usp. WELTE B., Meister Eckhart - Gedanken zu seinen Gedanken, str. 14.

${ }^{499}$ Usp. ENDERS M., Abgeschiedenheit - der Weg ins dunkle Licht der Gottheit. Zu Bernhard Weltes Deutung der Metaphysik und Mystik Meister Eckharts, str. 8-9.; Usp. također ŠEVO I., Vizija svijeta u filozofiji Meister Eckharta, u: HUM, Časopis filozofskog fakulteta Sveučilišta u Mostaru, 11 (2016) 16, str. 151.

${ }^{500}$ Usp. WELTE B., Filozofija religije, str. 176.

501 ŠEVO I., Vizija svijeta u filozofiji Meister Eckharta, str. 143-162.

${ }^{502}$ Usp. Isto, str. 151. 
Odvojenost od svijeta Eckhart preporučuje kao i odvojenost od stvorenja u svijetu, kako bismo mogli imati, te nam svijet i bića u njemu tada postaju beskrajno zanimljivi čak i u njihovoj konačnosti. ${ }^{503}$ Razlog ovog divljenja svaki čovjek treba pronaći u sebi, u svojoj nutrini i zato se Eckhart toliko zalaže za odvojenost od svijeta, neopterećenost i nenavezanost na bilo što izvanjsko, jer samo tada to jest u potpunoj odvojenosti i nenavezanosti čovjek može pronaći svoj vlastiti put i smisao. Kada se radi o iskustvu koje osoba stječe kroz život tada je njemački mistik bio čvrstog uvjerenja kako je vrjednije poučavati životu i kako je vrjedniji jedan učitelj života, negoli tisuću učitelja čitanja. On je, stoga, razlikovao naravno znanje (sveukupno filozofsko znanje) od nadnaravnog znanja, te za ljudsko znanje kaže da je »posuda« koja skriva nadnaravno znanje. ${ }^{504}$ Kroz svoje tumačenje pojma osobe Welte je usko vezao pojam iskustva $i$ to faktičnog životnog iskustva, kakvo samo čovjek ima i proživljava na tom putu duhovnosti i duhovnog življenja. S obzirom na ovaj Eckhartovski element iskustva općenito, Welte će kazati kako ljudskom opstanku u svijetu pripada svjetloća ili otvorenost mogućim iskustvima koja stječemo na nama samima, našem svijetu i u društvu u kojem živimo. ${ }^{505}$ Sam govor o opstanku u svijetu, naime, uključuje uvijek upravo i govor o različitim iskustvima. Tu se ne radi samo o fizičkoj prisutnosti pojedine osobe koja je tu i sada. Govor o iskustvu nikada nije ograničen nego pruža nebrojene mogućnosti ostvarenja pojedinca. U središtu Welteovih promišljanja se nalazi ona glasovita mistagoška vrlina za koju se Eckhart zdušno zalagao - vrlina unutarnje čovjekove skromnosti. Eckhartove misli navele su Weltea da se zalaže za vlastito razumijevanje svega što se nalazi unutar svijeta, i shodno tome, onoga što prekoračuje granice našega vidljivoga svijeta.

Na tom se tragu Welte pita što to znači za čovjeka današnjice »misliti za sebe«? Odmah se primjećuje kako je Welte ovdje posegnuo za dvojakim pristupom u tumačenu M. Eckharta: fenomenološkim na jednoj i spekulativnim na drugoj strani. Iako bi možda neki očekivali povijesno-kritički pristup, on se ovdje jednostavno ne da iščitati. Konačno to Welteu nije cilj i to prvotno iz toga razloga, što on ne želi pisati Eckhartovu biografiju. Welte želi pokazati da (Eckhartovo) iskustvo predstavlja uistinu bogatstvo za čovjeka koji je (danas) tu, ispred njegova djela, koji ga čitajući sluša (slično kao i oni kojima je tako zdušno propovijedao). Slušajući koncept je ovdje iznimno važan, jer na njega polaže upravo i M. Eckhart ogromnu važnost jer se tek slušanjem ili bolje osluškivanjem stječu uvjeti religioznog

\footnotetext{
${ }^{503}$ Isto, str. 154.

${ }^{504}$ ECKHART M., Knjiga božanske utjehe - traktati i propovijedi, prev. Šoljić A., Naprijed, Zagreb, 1991., str. 332.

505 WELTE B., Filozofija religije, str. 55.
} 
izvršenja, to jest onoga što slijedi nakon njega (slušanja), a to su molitva, kult itd. Slušanje je zbog toga važnije od svakog govora, kako u svakodnevici, tako i posebno u religiji. U tom smislu posebno se važnim, štoviše krucijalnim za Welteovu filozofiju religije pokazao Eckhartov pojam „religioznog izvršenja“ čovjeka. ${ }^{506}$ Religioznom izvršenju pak prethodi religiozno postojanje, slično kao i kod odnosa virtus - vrlina i opus - djelovanje, čin. Naime, svakom dobrom to jest moralno ispravnom činu, prethodi moralno ispravan karakter. Prema njem. mistiku takav se karakter označava pojmom kreposni, vrli. Upravo u tom smislu te logičkom nužnošću, prethodi religioznom izvršenju, upravo religiozno postojanje za što Ekchart koristi pojam »Daseinvollzug«. Rabeći taj pojam, Welte ističe, kako je za izvršenje takvog postojanja potrebna upravo osamljenost koju je Eckhart uz šutnju iznimno zagovarao. Jedino osamljenost vodi čovjeka ka potpunom razumijevanju samog sebe, i drugih s kojima je u zajedništvu. Osamljenost je, kažu oba autora, stvar ljudskog postojanja, te unatoč ljudskoj manjkavosti, ako je čovjek predan onome što Eckhart naziva »tamno svjetlo božanstva«, tada mu upravo ona pomaže da zahvati i upozna samog sebe, svoje mane i vrline, kako bi mogao biti na raspolaganju Bogu i drugim ljudima. Uz osamljenost je prema Welteu potrebno još jedno stanje, za razumijevanja sebe samih te u konačnici Boga - pouzdanje. Najbliži smisao vjere, reći će Welte, može se okarakterizirati izrazom »pouzdati se u Boga«. ${ }^{507}$ Naš je filozof religije ovdje mislio na pouzdanje koje vodi k prepuštanju samih sebe onom drugom, to znači vječnom Bogu i od svijeta različitom Bogu. Uvjet tog prepuštanja jest, među ostalim, osamljenost, samoća.

Zanimljivo, oba autora, Eckhart i Welte, iznose svoje misli iz perspektive služenja drugim ljudima. Eckhart kao redovnik, dominikanac, teolog i mističar, a Welte kao (katolički) svećenik, teolog i filozof religije. Osamljenost je vrlina koja je prema Eckhartu iznad svih drugih. Osamljenost je, kako je spomenuto, usko povezana upravo s izvršenjem čovjekova postojanja. Eckhartovim riječima osamljenost je put koji vodi ljudsko postojanje, to jest osobu koja živi to postojanje u »tamnu svjetlost Božanstva«. To je bivanje i veza s Bogom i Božjim jedinstvom, prevladavanje radikalno metafizičkog mišljenja (odvojenog od egzistencijalnog momenta) i put na kojem se ljudsko iskustvo stopilo s ništavilom (koje predstavlja čovjekovu samoću u vidu odijeljenosti) te dovodi do konačnog ispunjenja - zajedništvo Boga i čovjeka, gdje čovjek više ne zadržava identitet kakav je imao na zemlji. ${ }^{508}$

\footnotetext{
${ }^{506}$ Krucijalnim jer će biti svojevrsna okosnica u Welteovoj filozofiji religije.

${ }^{507}$ Usp. WELTE B., Filozofija religije, str. 161.

${ }^{508}$ Usp. ENDERS M., Abgeschiedenheit - der Weg ins dunkle Licht der Gottheit. Zu Bernhard Weltes Deutung der Metaphysik und Mystik Meister Eckharts, str. 29.
} 
Uz samoću koja je bliska onomu što Eckhart označava pojmovima praznina, lišenost itd., Welte je iznimno puno promišljao o ništavilu, pri čemu se upravo nadahnjivao Eckhartom. Promišljajući o toj kategoriji ne-bitka Welte usko razmatra i ne-opstojanju koje predstavlja određenu negaciju. Ne-postojanje je također pripadno čovjeku u smislu da nekada nije bio, i da jednom opet neće biti - tu gdje je sada i takav kakav je sada. Kao i za Eckharta to ništavilo ne predstavlja za Weltea apsolutnu negativnost već suprotnost postojanju Boga koje je radikalna pozitivnost. Čitava je ljudska egzistencija, dakle, protkana ne-postojanjem. Welte to pogođeno opisuje kada kaže: „Nitko i ništa što je ljudsko ne izmiče ne-opstojanju.“509 Ljudski opstanak u cjelini biva, dakle, uključen u ovo ne-opstojanje i uvijek biva pogođeno njime kako za života, tako i na njegovu prestanka.

\subsection{Pitanje o Bogu: Meister Eckhart i Bernhard Welte}

Pitanjem o Bogu bavili su se u okviru filozofije mnogi kroz čitavu njenu povijest. Poteškoće se pak javljaju već prilikom samog razumijevanja istoga pitanja. Boga, naime, nije moguće definirati niti jednom od mogućih definicija, nije ga moguće opojmiti, jer on je, riječima Anselma Canterburyjskog, veći od svega što možemo reći. Možemo se složiti s I. Ševom koji proučavanju M. Eckharta i njegova razumijevanja Boga, donosi sljedeću tvrdnju: „Bog je za čovjeka svih vremena jednostavno onaj nepojmljivi, neizmjerni, neizrecivi, onaj kojega nije moguće definirati - Bog nadilazi svijet i čovjeka i ujedno ih na svoj božanski način prožima. On prebiva u svijetu, obuhvaća ga, a ipak s njime ne može biti identičan““. ${ }^{510} \mathrm{U}$ svoj govor o Bogu Eckhart usko vezuje i tumačenje o duši kao prisutnosti nestvorene božanske svjetlosti ili Božjeg trinitarnog duha koji je u ljudskom duhu i kojem je potrebna korekcija. ${ }^{511}$ Prema mnogim autorima, Eckhartova je temeljna misao rađanje Božje riječi (Sina ili Logosa) u čovjekovoj duši, dakle susret čovjeka s Bogom, ne kao ezoteričan doživljaj, nego kao strukturna karakteristika svake čovjekove egzistencije u njezinoj slobodi. ${ }^{512}$ Božja razumnost je najviša odlika Boga, razumnost koju posjeduje čovjek je prema Eckhartu je jedinorođeni Sin Božji. ${ }^{513}$ Ovo je misao koja je bila od najveće važnosti u Eckhartovu promišljanju o duši gdje se sam Bog nastanio u čovjeku. Otkrivanje Boga u

\footnotetext{
${ }^{509}$ WELTE B., Filozofija religije, str. 57.

510 ŠEVO I., Vizija svijeta u filozofiji Meister Eckharta, str. 143.

${ }^{511}$ Usp. Isto, str. 143.

512 Isto, str. 148.

${ }^{513}$ Usp. Isto, str. 148
} 
vlastitoj duši jest dostupno prema Eckhartu svakome čovjeku. To je mogućnost koju posjeduje svaki čovjek samim time što je Božje stvorenje. ${ }^{514}$

Welte, nadalje, razmatra o Bogu kao izvorištu slobode za čovjeka. On ga slobodom jednostavno obdaruje, bilo u egzistencijalnom momentu temeljnog opredjeljenja, bilo pak u svakodnevnim pojedinačnim izborima. U tom smislu upravo po slobodi čovjek ima mogućnost i odustajanja od namjeravanih čina, kao i njihovu korekciju ako je to nužno, kao bi ih usmjerio prema dobru kao takvom, pri čemu je očito, da njemački mistik slobodu nužno vezuje, štoviše uvjetuje dobrotom. Kada se radi o Eckhartu i njegovu poimanju slobode, ono je, nadalje, usko vezano uz doživljaj i prepoznavanje Boga unutar čovjekove egzistencije koja se događa u slobodi. Bog se (pre)daje čovjeku te ga „poziva“ na prepoznavanje to jest odgovor. Svaka je osoba, pak, slobodna na različite načine (ne samo kroz meditaciju nego i svakodnevne aktivnosti) prepoznati tu božansku iskru duše koja se očituje upravo u vlastitoj slobodi. ${ }^{515}$ Navedene mogućnosti odgovora u slobodi, pretpostavljaju svojevrsnu „slobodu u slobodi“, to jest temeljno stanje ne-navezanosti u smislu izvjesne „slobode od“. U tom je smislu iznimno važno kod Eckharta i njegova poimanja slobode upravo to da osoba općenito ne bude navezana na svijet. Ona istina živi i djeluje u svijetu, s njih ophodi i djeluje, međutim $\mathrm{u}$ isto vrijeme ima zadaću nadilaženja tog istog svijeta, u slobodi i vlastitom (duhovnom) opredjeljenju. U suprotnom ostaje, prema našem mistiku, rob svijeta. ${ }^{516}$ To robovanje svijetu, nasuprot uvriježenom očekivanju, izvorište je trajnog nezadovoljstva za čovjeka. Sloboda, pak, koja izvire iz vjere i osobnog predanja svakog pojedinca Tajni koja ga nadilazi, jest uvijek pozitivna, te ju Welte označava kao osobni polet koji je istinska posljedica oslobađanja od svijeta. ${ }^{517}$ Valja ukazati da stavu o oslobađanju od svijeta, leži Eckhartovo te uvjerenje općenito o prolaznosti i nestabilnosti zemaljskoga života odnosno svijeta općenito. Te misli su bile povezane pa i uvjetovane s vremenskim prilikama i neprilikama u kojima je sam živio i djelovao. Bio je to srednji vijek, vrijeme prirodnih nepogoda, katastrofa i pojava tzv. crne smrti, odnosno neizlječive bolesti kuge. Eckhart se u tom smislu uvijek obraćao običnom puku, najčešće je govorio u vidu propovijedi koje su služile kao utjeha uslijed spomenutih nepogoda koje su tada vladale.

Na pojam slobode, nadovezuje se u Welteovu razmatranju Eckharta i stvarnost patnje. Patnja kao doživljaj jedan je od važnih aspekta božanskog bića pri čemu Welte upućuje na

\footnotetext{
${ }^{514}$ Usp. Isto, str. 148

${ }^{515}$ Usp. Isto, str. 151.

${ }^{516}$ Usp. Isto.

${ }^{517}$ Usp. WELTE B., Filozofija religije, str. 159.
} 
krucijalnu razliku između Boga filozofa (posebno Aristotelovog boga) i Boga vjere, (u tradiciji Boga Abrahama, Izakova i Jakova). Grčka filozofija naime, kao primjerice i monoteistička religija islam, ne mogu ,izići na kraj“ s Bogom patnikom. Prema tom uvjerenju, ovaj atribut Boga srozava na „nedostojnu“ razinu onog ljudskog, očitujući njegovu slabost. Bog patnik pak biblijsko-kršćanskoj tradiciji ukazuje na sućutnog Boga, pri čemu se njegovo božanstvo upravo u patnji upotpunjuje. O time postaje ne manje već „više Bog“ bivajući u isto vrijeme utočište i nada svima onima koji pate. ${ }^{518}$

Vezano uz pitanje o Bogu kod Eckharta dolazi do izražaja i pitanje vječnosti intelekta jer intelekt je za njega smješten u duši i označava prisutnost božanskog bića u čovjeku. »Vječni intelekt« za Eckharta je Bog, koji otvara viša osjetila, odnosno prodire u samu osnovu božanskog bića. ${ }^{519}$ To bi pak dalje značilo da svaka ljudska duša sudjeluje u sudbini svijeta, ima svoje mjesto u trenutku spasenja i otkupljenja te da u taj vječni i beskrajni Um koji je sam Bog stanu sve naše boli, grijesi i nadanja tako nitko nije izgubljen niti zaboravljen. ${ }^{520}$ Svaka ljudska duša je posebna, ima svoju vlastitost odnosno originalnost $\mathrm{i}$ stoga joj je samo vječnost granica. ${ }^{521}$

Put do Boga, prema Eckhartu je, dakle, put odricanja od svijeta, sebe i od Boga kakvog mi u svojoj konačnosti zamišljamo. Zbog toga je Eckhart pokušao naći precizan put koji bi vodio do razumijevanja Boga i njegova božanstva. Da bi to uspio, on prvotno polazi, kako smo vidjeli, od čovjekove nutarnjosti, koja treba biti slobodna od svih izvanjskih formi i utjecaja. Weltea se posebno dojmila ta misao jer je i on sam zagovarao svojevrsni apriorni put u pristupu Bogu, što znači put, već spomenute šutnje i predanost Tajni (Bogu) kojoj je čovjek okrenut. Istinska se šutnja može, prema Eckhartu ostvariti jedino na radikalni način: kroz odreknuće osobe od same sebe i svijeta, kroz molitvu te okretanje Tajni kojoj se predaje i kojoj se prinosi. Iz te šutnje proizlazi životnost, koja nije suprotnost šutnji, već upravo suprotno, očituje njeno upotpunjenje odnosno posljedicu. Plod istinske šutnje je duboko duhovno zadovoljstvo. Iz šutnje se dade dakle iščitati religiozni odnos kao takav.

U Eckhartovim je promišljanjima čovjekova odnosa prema Bogu, - koji Welteovim rječnikom valja promatrati kao autentično izvršenje religije -, središnja je postavka ta da se

\footnotetext{
${ }^{518}$ Usp. Isto, str. 154.

519 Usp. EBELING H., Meister Eckhart Mystik. Studien zu den Geisteskämpfen um die Wende des 13. Jahrhunderts, Stuttgart, 1941., str. 203., 205., 320., te 327-328.; Usp. također KERN U., Rezeption Eckharts im Protestantismus, u: Meister Eckhart und Bernhard Welte. Meister Eckhart als Inspirationsquelle für Bernhard Welte und für die Gegenwart, LIT Verlag, Berlin, 2015., str. 31-101.

${ }^{520}$ Usp. ECKHART M., Knjiga božanske utjehe - traktati i propovijedi, str. 332.

${ }^{521}$ Usp. Isto, str. 332.
} 
ljudi moraju osloboditi svake žudnje, zatim svake pohlepe za imovinom i ujedno svake strukture imanja jer su sve etičke norme ukorijenjene u etici bivstvovanja, dijeljenja i solidarnosti. ${ }^{522}$ Možemo reći kako je Eckhartov zahtjev išao u smjeru odustajanja od onog izvanjskog, a posebice je isticao služenje u duhu spram bližnjega. Svoje stavove gradio je na čvrstom uporištu, Isusu Kristu, koji je za njega bio junak ljubavi, junak bez moći, koji nije htio vladati niti išta imati. ${ }^{523} \mathrm{Na}$ sličan način promišlja i Welte koji Boga naziva vječno »ti« koje se pojavljuje u ljudskom iskustvu na način Ljubavi, te izuzet od svake moći i pogotovo sile, postaje paradoksalno čovjekov sluga. Welte je, valja to također uočiti, ipak suzdržaniji od Eckharta kada su u pitanju pojmovi „sjedinjenja“ i „stapanja“, čovjeka s Bogom, te u izvornom biblijskom duhu, zadržava princip razlike između čovjeka i Boga, te njihovu udaljenost označava jednostavno pojmom Božje transcendencije. Ona, pak, vodi k tomu da se ono vječno »ti«, koje čovjeka „snalazi“ ne samo njemu (čovjeku) približava, nego ga i pogađa u njegovoj najdubljoj nutrini. To pogađanje ima značajku odnosa, koje je ono najprisnije $\mathrm{i}$ najpotpunije pogađanje i koje se ne može mjeriti ni s čim drugim sličnim po pitanju odnošenja.

Iskustvo koje osoba proživljava u svojoj nutarnjosti, koja se oslobodila »okova« izvanjskog, jest put koji vodi $\mathrm{k}$ istinskom spoznavanju. O pojmu spoznavanja Eckhart veli sljedeće: „Nijedan čovjek nije nikada tako jako nešto želio kao što Bog želi dovesti čovjeka do toga da ga on spozna. Bog je uvijek spreman, ali mi smo veoma nespremni; Bog je nama blizu, ali smo mi od njega daleko; Bog je unutra, ali smo mi vani; Bog je (u nama) doma, ali smo mi u tuđini.““524 Prema njemačkom mistiku, jedino nas filozofija prirode uči kako postoji univerzalna istina koja je srž svih religija i kako su sve religije u osnovni odraz istoga nastojanja, samo prilagođene određenom vremenskom i kulturnom te religijskom okružju. ${ }^{525}$ Welte je bio mišljenja da ondje gdje se Bog pojavljuje, pojavljuje se za nekoga i neku zajednicu, a njegovo pojavljivanje najčešće utemeljuje neku zajednicu. Time Bog za dotičnu skupinu ili religijsku zajednicu postaje »naš« Bog, poistovjećuje se s tom skupinom i ona $\mathrm{s}$ njim te zajedno postaju $» m i \ll .{ }^{526} \mathrm{Na}$ tom putu, reći će Welte, treba prevladati ljudski egoizam i sve ono suviše ljudsko kako se ne bi bacila mrlja na Božji lik.

\footnotetext{
${ }^{522}$ Usp. ŠEVO I., Vizija svijeta u filozofiji Meister Eckharta, str. 143-144.

${ }^{523}$ Usp. ŠEVO I., isto, str. 143.

${ }^{524}$ Usp. ECKHART M., Deutsche Predigten und Traktate, Carl Hanser Verlag, München - Wien, 1963., str. 353.

${ }^{525}$ Usp. ŠEVO I., Vizija svijeta u filozofiji Meister Eckharta, str. 144.

${ }^{526}$ Usp. WELTE B., Filozofija religije, str. 139.
} 
Na tragu stalnog oslobađanja kao i odricanja, Eckhart je stava, da je, osim od svijeta kao takvog, prijeko važno oslobađanje nas ljudi od vlastitih posjedovanja te (čak) i vlastitih djela, a sve kako ne bismo bili sputani. Na tome putu od pomoći su volja i uvjerenje. Prema Eckhartu, upravo je navezanost jedan od glavnih problema na putu spoznavanja. Navezanost u najduljoj osnovi onemogućava našu slobodu. Stoga je cilj kojem treba stremiti živo iskustvo Božjega rođenja u svakom pojedinom čovjeku jer jedino on na istinit način, prema ovom mistiku, oslobađa. Volja i stav su karakteristike i u Welteovu tumačenju ljudskog postojanja. Upravo kroz volju osoba usmjerava svoje djelovanje, odlučuje se između dobra i zla. Stav je onaj koji omogućuje čovjeku preuzimanje odgovornosti prilikom aktualiziranja pripadne mu slobodne volje. Ne treba smetnuti uma u kontekstu ove rasprave, da se u Eckhartovo vrijeme javlja i nominalizam, koji osim području spoznaje kao takve, također uzrokuje i mnoge promjene u pogledu čovjeka i njemu pripadnih svojstava. ${ }^{527}$ Zasigurno, ne može se reći da je Eckhart potpuno potpao pod utjecaj ovog filozofskog pravca - on ostaje vjeran njemačkoj te mistici općenito. Međutim, izvjesno je kako su pojedini aspekti nominalizma u pogledu primjerice shvaćanja slobode, odnosno njezina konkretiziranja u pojedinačnim odlukama, kod ovog filozofa primjetni.

Već spomenuta, za ono vrijeme sablažnjiva misao rađanja Boga, odnosno Božje riječi u čovjekovoj duši jest jedna od temelja Eckhartovih promišljanja o Bogu. Time on pokušava domisliti susret čovjeka s Bogom, međutim ne kao ezoterični doživljaj, nego kao strukturnu karakteristiku čovjekove egzistencije koja sama po sebi stremi sebe-nadilaženju u njezinoj

\footnotetext{
${ }^{527}$ Nominalizam. U filozofiji, jedan od dvaju glavnih smjerova skolastičke filozofije po kojem nisu primarne opće ideje, nego samo pojedinačne stvari. Opće ideje (universalia) postoje samo poslije stvari (post res) kao imena koja su čisti jezični izrazi (flatus vocis), za razliku od suprotnoga smjera realizma, po kojem univerzalije postoje prije stvari (ante res). Problem univerzalija postavio je prvi Porfirije u svojem komentaru Aristotelovih kategorija. Poslije je u skolastici glavni predstavnik nominalizma Roscelin, kojeg je Crkva osudila u Soissonsu 1092. U XIV. st. obnovio je nominalizam W. Occam. U suvremenoj je filozofiji opet oživio svojevrsni nominalizam, pa mnogi predstavnici empirizma i pozitivizma poriču da najveći dio općih filozofskih termina ima objektivni korelat u stvarnosti. Suvremeni nominalisti, posebice N. Goodman i W. V. Quine, pozornost više usredotočuju na pitanje o designatama subjektivnih izraza, posebice onih koji se u fundamentalnom matematičko-logičkom istraživanju shvaćaju kao imena za skupove, što svoje uporište ima već kod B. Russella i G. Fregea, u: BROZOVIĆ D., KOVAČEC A., RAVLIĆ S., Hrvatska enciklopedija, mrežno izdanje. Pristupljeno 28. 9. 2020. Dostupno na: http://www.enciklopedija.hr/natuknica.aspx?id=44028
} 
slobodi. ${ }^{528}$ To je ona božanska iskra duše (Seelenfunken), onaj božanski temelj duše (Seelengrund), što povezuje u mistično jedinstvo čovjeka kao stvorenje $\mathrm{s}$ njegovim Stvoriteljem. ${ }^{529}$ Bog u svojoj najdubljoj nutrini jest »tiha pustinja Božanstva« (stille Wüste der Gottheit) iz koje proizlazi Božje Trojstvo. ${ }^{530}$ Božja razumnost je pri tom, prema Eckhartu, vrhunac Božje biti, a čovjekova razumnost je najviša čovjekova odlika. Ta razumnost, koja se nalazi u središtu čovjekove duše je jedinorođeni Sin Božji. ${ }^{531}$ Pojam »tiha pustinja« rabi Eckhart kako bi opisao nešto što se ne može opojmiti ni definirati niti jednom definicijom. Otkrivanje Boga u vlastitoj duši je nešto što nije privilegija odabranih, nego je svakome dostupno, samo je potrebno otvoriti se i osluškivati, odbaciti sve ispraznosti te se odvažiti ka putu spoznaje. To je mogućnost pripadna svakome čovjeku kao Božjem stvorenju. Na putu ostvarenja te mogućnosti nisu samo molitva i meditacija one koje vode ka tomu, već svaka aktivnost u svijetu. Bitna je čovjekova uloga u svijetu. Uistinu, čitav je svijet stvorenje Božje i u njemu se očituje slava Božja. ${ }^{532}$ Stoga se pravednik se u svijetu prepoznaje po njegovu ponašanju prema drugom čovjeku, prema zajednici u kojoj živi. Eckhart prepoznaje svijet kao sakrament Božji i u služenju svijetu nadilazi svoj uskogrudni ,ja““ i ujedno s Kristom, Logosom na neki način postaje cijelo čovječanstvo. Prema Eckhartu, aktivni i kontemplativni dio života su upućeni jedan na drugoga i upotpunjuju se. Smisao kontemplacije je u akciji koja nakon te kontemplacije slijedi. Stoga, djelatni život ocjenjuje, Eckhart vrjednijim jer tako pretačemo s ljubavlju u praksu ono što smo u kontemplaciji spoznali. ${ }^{533}$

Pored naznačenog zahtjeva za djelatnom ljubavlju Eckhartovu misao svakako možemo označiti kao metafizičko-mističku, štoviše i kao onu koja je bliska, u pojedinim momentima i identična klasičnom panteističkom stavu. Međutim, ona je Welteu, utoliko bliska, jer se

\footnotetext{
${ }^{528}$ Usp. ECKHART M., Deutsche Predigten und Traktate, str. 307. „Budući da je dakle Božja narav da on nije nikome sličan, to moramo nužno doći do toga da smo mi ništa, da bismo mogli biti preneseni u isti bitak koji on sam jest. Ako ja prema tomu dolazim do toga da ja sebe uobličim u ništa i u se ništa uobličim, te izbacim (sve) što jest u meni, onda mogu biti prenesen u čisti Božji bitak, a to je bitak duha. Tu mora biti istjerano sve što je (na bilo koji način) sličnost, da bih ja bio u Boga prenesen i s njim postao jedno i jedna supstancija, jedan bitak i jedna narav te (s tim) sin Božji. A nakon što se to dogodilo, ništa (više) nije skriveno u Bogu što ne bi postalo očito ili ne bi bilo moje. Tada ja postajem mudar i moćan i sve stvari poput njega, i jedan te isti s njim. (...) Ako bi ikakva slika ili išta slično u tebi ostalo, ti nikad ne bi postao jedno s Bogom. Stoga: da bi ti bio jedno $\mathrm{s}$ Bogom, u tebi ne smije biti ništa u-'slikano' ni iz-'slikano', to znači da u tebi ne bude ništa skriveno što ne bi bilo očito i izbačeno.“

${ }^{529}$ Usp. ŠEVO I., Vizija svijeta u filozofiji Meister Eckharta, str. 148.

530 Isto, str. 148.

531 Isto, str. 148.

532 Isto, str. 149.

${ }^{533}$ Isto, str. 150. Navedena razmatranja ne dolaze u sukob s Eckhartovim stavom o odricanju od svijeta, nego upravo upotpunjuju. Naime, odricanje od svijeta biva uvjet istinskom okretanju drugima u svijetu te pristupanje svijetu na drugačiji način. Ne potrebujemo li i danas takav paradoks? Odvojiti se od svijeta (ekološka, humanitarna itd. pitanja) da bi smo mu se na drugačiji način približili.
} 
suvremeni njemački filozof na njoj nadahnjivao upravo u razmatranjima osobe i njezina doživljaja Boga. Kada se ovomu dodaju pojmovi poput susreta, tišine, vrline, unutarnje skromnost i pobožnost, koje Welte obilato koristi u svojoj filozofiji religije, tada je utjecaj Ekcharta na njega neporeciv. U većini Welteovih spisa ljudsko biće - osoba jest u središtu pozornosti. ${ }^{534}$ Iz te pozicije, odnosno ishodišta, Welte biva iznimno zainteresiran za osobu uopće njeno dostojanstvo, temelje njena postojanja, u kojima je susret s drugim čovjekom, kao i samim Bogom, tematiziran kao osnovno iskustvo slobode. Također, u razgovoru s prirodnim znanostima svoga doba, poglavito onima o čovjeku, freiburški je filozof religije formulirao odgovor na mogućnost ljudske slobode jer se upravo iz/po slobodi dolazi do odgovora na pitanje o čovjeku i njegovom osobnom dostojanstvu - kako u prošlosti tako i sadašnjosti. Nema ljudskog dostojanstva, bez priznanja i konkretne potvrde njegove slobode, u supstancijalnom i duhovnom (duhovnom - ne strogo religijskom) pogledu. Nju je upravo naglašavao i na poseban način promovirao M. Eckhart.

$\mathrm{Na}$ temelju svega rečenog može se zaključiti kako Welte pokušava učiniti vidljivim trag vječnog $u$ fenomenima prirodnog svijeta i ljudske povijesti. ${ }^{535}$ Welte traži trag sudjelovanja svih stvari u vječnom Božjem otajstvu i iz toga razloga se posebno bavi osobnim iskustvom Boga u okviru ljudskog postojanja. ${ }^{536}$ To je i poziv i zahtjev koji se nameće pred svakog pojedinca u njegovu postojanju i kršćanskom životu. Osoba je ona koja ima slobodu od Boga darovanu i proživljava iskustvo tog istog Boga kroz vlastito postojanje i egzistenciju. U slobodi i donošenju svakodnevnih odluka te napose u susretima s drugim ljudima, osoba može doživjeti iskustvo vjenčanosti i neprolaznosti. Sloboda naime, ako specifično duhovna kategorija upućuje upravo na svoj iskon, a taj je da ona za pozadinu to jest vlastiti temelj ne može imati nešto materijalno i konačno. U tom smislu, Welte, s obzirom na čovjekovu slobodu te u bitnom oslanjanju na Eckharta ističe, kako u svakom čovjeku postoji trag vječnoga, odnosno samog Boga. To je poziv na otkrivanje Boga kako u nama samima (po slobodi) tako i u drugim ljudima te konačno pojavama i u okviru povijesti, koje u svojoj izazovnosti i ,nesređenosti“ mogu biti poticaj traganja za Bogom. Iz toga razloga potrebno je kroz susret s drugim i drugačijim cijeniti i štoviše ophoditi se sa strahopoštovanjem prema njegovoj slobodu kao i pripadno mu dostojanstvo samim time što je čovjek i što mu je

\footnotetext{
${ }^{534}$ Usp. WELTE B., Gesammelte Schriften I/1 Person, str. 288.

535 Usp. WELTE B., Meister Eckhart - Gedanken zu seinen Gedanken, str. 268.

${ }^{536}$ Usp. WELTE B., Gesammelte Schriften II/1: Denken in Begegnung mit den Denkern I: Meister EckhartThomas von Aquin - Bonaventura, str. 368.
} 
ishodište u Bogu. Samo ćemo na taj način, prema Welteu, moći hrabro odgovoriti na poziv života koji vodi k vječnosti u Bogu.

\subsection{Zaključni izvodi o Eckhartovoj misli i Welteovu oslanjanju na njemačkog mistika}

Kao uistinu osebujan i originalan mislilac te ujedno i mistik, Eckhart stavlja pred ljude veliki, duhovno maksimalan zahtjev koji je zasigurno teško ispuniti. Ipak, njega valja shvatiti u kontekstu onoga što je činio, stvarao i načina na koji je to stvaranje aktualizirao: temeljni mu je cilj bio razmotriti čovjekov odnos prema Bogu te vlastitom postojanju i pokazati mu put ispunjenja, sreće i unutarnjeg stanja pune spremnosti u kojoj se može predati volji Onoga kojeg nazivamo Apsolutnim, Bogu. Iako je u ovom kontekstu teško govoriti u tim kategorijama (ispunjenja, sreće, spremnosti), ipak možemo ovdje hrabro ustvrditi da su netom navedena tri pojma ipak došla do svojeg očitovanja u Eckhartovoj filozofiji utoliko što zdrav razum te svakodnevno iskustvo života pokazuje da izazove zemaljskoga života daleko bolje svladavaju oni koji su u duhu Božjemu iznutra odvojeni od onih kojima nedostaje ovaj mir, odnosno spokoj. Welteu se upravo Eckhart pokazao kao onaj koji može dobro i valjano tumačiti taj put osame koji vodi ka Bogu: »Jer samo nakon mjere našeg spokojstva i unutarnje osame, Božja volja i mir mogu biti učinkoviti u nama«. ${ }^{537}$

Sve što je Eckhart rekao vezano uza Boga i vezano uz »tamno svjetlo božanstva«, rekao je u kontekstu da je samo jedan pravi Bog, onaj koji postoji od vjekova. Međutim, Eckhart priznaje da ima i mnoštvo drugih bogova, kojima se ljudi klanjaju (lažni bogovi, kumiri, idoli koje Welte, kao i Eckhart također navodi). Od mnoštva tih koji se pojavljuju na sceni svijeta i povijesti, u koje ljudi još uvijek vjeruju, taj jedan pravi Bog često ne dolazi do izražaja, ne dolazi do svojeg očitovanja, upravo zbog zaglušujuće buke koja se pri tome javlja. Doći odnosno približiti se „božanskom“ Bogu, koji je od ovog svijeta odvojen, može se jedio izdizanjem iznad ovozemaljskog i uopće ljudskog, da bi se moglo prepustiti onom što nazivamo Vječnim. Čovjek biva sposoban spoznati pravu čistu Ljubav koja sve nadilazi tek tada, kada je, Eckhartovim riječima, čovjekovo srce usmjereno ka Nebu. Upravo tada, koliko god to banalno za nas suvremenike zvučalo, čovjek shvaća sve zemaljsko prolaznim. ${ }^{538} \mathrm{Svi}$ smo mi, prema Eckhartu, samo putnici na ovom zemaljskom tlu, te se treba trajno zapitkivati,

\footnotetext{
${ }^{537}$ Usp. ENDERS M., Abgeschiedenheit - der Weg ins dunkle Licht der Gottheit. Zu Bernhard Weltes Deutung der Metaphysik und Mystik Meister Eckharts, str. 29.

${ }^{538}$ Usp. ECKHART M., Knjiga božanske utjehe - traktati i propovijedi, str. 332.
} 
hoćemo li završiti svoje ovozemaljsko putovanje praznog srca, prazne duše? Eckhart je tu stava, da potpuna odgovornost leži na nama samima. Duše se često gube u grijehu egoizma i samodopadnosti pa naravno shodno tome nestaje poniznost i drugi plodovi savjesti. Zbog toga čovjek često izgubi samog sebe na tom putu. Iako u trajnom zahtjevu (reformanda) obnove zbog vlastite grešnosti odnosno njenih članova, katolička Crkva je, za Weltea još uvijek istinsko svjetlo u tami. Naš je filozof religije svojoj Filozofiji religije jednostavno ustvrdio kako vjera koja se rađa u čovjeku i unutar katoličke Crkve nikada ne umire, može se istina izgubiti, ali uvijek se iznova vraća, još jača i postojanija nego prije. Razlog tom uvjerenju o vjeri kod Weltea, leži u činjenici Crkve kao zajednice vjernih.

Osim Weltea, postoji čitava plejada njemačkih suvremenih filozofa i teologa koji se duboko nadahnjuju M. Eckhartom. Jedan od njih, za nas vrijedan spomena, je i Dietmar Mieth, suvremeni teolog i socijalni etičar. Mieth na poseban način ističe vrijednost Eckhartovih misli za suvremenost. Prema D. Miethu, misao Meister Eckharta je od velike važnosti i predstavlja nepresušan izvor misli za sve one koji se bave vjerskim i međureligijskim temama. Eckhart je, prema ovom njem. moralnom teologu, razvio neovisnu filozofiju i teologiju, koja je već u Eckhartovo vrijeme mnoge fascinirala i iznova otkrivala nove stvarnosti. Dietmar Mieth Eckharta prikazuje kao mislioca, propovjednika ali i učitelja života. Ne doživljava ga tek kao povijesni fenomen, već kao preteču onoga što se kasnije pokazalo jednom novom etapom u povijesti filozofije mistike i života. Mieth smatra kako je Eckhart blizak filozofiji na način vizija i posebnih iskustava koje pretače u misli koje su ostale zabilježene u mnogim Eckhartovim djelima. Miethu su se posebno zanimljivim pokazali Eckhartovi govori o prevladavanju svakodnevne svijesti. Pod pojmom svakodnevna svijest ovdje se razumije „stanje duha“ s obzirom na kontekstualnost i okolnosti pod čijim utjecajima (sami) razmišljamo i djelujemo. Te projekcije, pak, utječu, kao je već spomenuto i na čovjekov doživljaj odnosno shvaćanje Boga. Zbog toga se, prema Eckhartu, čovjek susreće s Bogom i Božjom moći u najdubljoj osnovi vlastitog bića, lišenog dakle svakog utjecaja. U tom pak sjedinjenju čovjekova ,ja“ s Božjim ,ja“, događa se uistinu nešto moćno: Eckhartovim riječima, na djelu je samo rađanje Boga u vlastitoj duši te posljedično u svemu onome što čovjek misli i stvara. Mieth pokušava ukazati da se ovo susretanje u Eckhartovu smislu ne događa tek na razini mističnog uvida i spekulacije već ima i svoj konkretni učinak ispunjenje i zadovoljstvo vlastitim životom, koje se pak manifestira u svakom pojedinačnom djelovanju te posebno susretu i odnosu s drugima. Neće stoga biti nimalo začudno kada Dietmar Mieth o Eckhartu to jest njegovoj filozofiji, veli sljedeće: „Eckhart nudi lijek za stres, 
izgaranje, gubitak značenja: odvojenost, unutarnju distancu, spokoj, osjećaj vremena za sadašnjost, osjećaj vjerske neposrednosti; njegove riječi su neprestani izvor vitalizacije života. “539 Vezano uz svojevrsnu ,aktualnost“ i ,praktičnost“ Eckhartove filozofske misli za suvremenost, (iako se u kategorijama treba s obzirom na Ekcharta govoriti vrlo uvjetno) Mieth ističe da Eckhartove postavke u povratku u nutrinu ukazuju da čovjek mora „trenirati“ vlastitu svijest, koja se izgrađuje vlastitim djelovanjem, ne prvotno učinkom prema van, nego upravo unutarnjim posvješćivanjem objektivnosti i realnosti vlastitog ja. U tom smislu čovjek mora, koliko god je to moguće, biti jasan samom sebi, bivajući upravo tako autentičan u svom postojanju. Osim u činu čiste theoria-e motrenju vlastitog ja, to se samospoznavanje događa i u perspektivi (vlastita) dobra. Štoviše upravo nam je reminiscencija na (vlastito) postignuto dobro, često svojevrsni izlaz u tami gubitka vlastitog ja te u doslovnom smislu riječi služi kao izlaz ako nam više ništa ne može pomoći na tom putu samospoznavanja. ${ }^{540}$ Vrijednost odnosno dobro kao takvo, ima svoju aksiološku gustoću bitka, onoj jest i kao takvo realno postoji. Upravo po toj gustoći, ono biva svojevrsni most, do kojeg dolazimo k sebi. U zlu, nasuprot toga, naše se ,ja“ rasplinjuje. To je naravno suprotno sveprisutnim trendovima današnjice, jer zahtijeva hrabrost suočavanja s onim najautentičnijim i najizvornijim u nama samima.

Navedeni prikaz Eckhartove filozofije kao i naše pozivanje na suvremene filozofe i teologe poput ovdje spomenutog D. Mietha, potiče mnoga pitanja, kako vezano uz tumačenje čovjeka i rascjepa u njemu između onog ljudskog i božanskog, tako generalnog odnosa to jest problema suprotstavljanja teološkog puta filozofskom. U tom smislu veli primjerice autorica M. Roesner u svome bavljenju Eckhartom kako je odnos između filozofije i biblijske teologije objave jedno od najnapetijih i osnovnih pitanja zapadne intelektualne povijesti. ${ }^{541}$ Eckhartova interpretacije ljudskog razuma pokazuje kako nema rascjepa između filozofije i teologije, ali nema razlike niti između teoretske znanosti i vjerske životne prakse. Eckhart prati sve oblike znanja o sebi, svijetu i Bogu sve dok ne dođe do čistog, ,ja ${ }^{\text {ee }}$ kao njihovog zajedničkog izvornog principa. Svakako, spomenuta autorica Roesner pak u svome bavljenju Eckhartom ističe kako je krucijalan pojam, na kojem se treba zadržati prilikom proučavanja M. Eckharta,

\footnotetext{
${ }^{539}$ Usp. MIETH D., Meister Eckhart als spirituelles Vorbild und theologische Herausforderungen, u: Meister Eckhart und Bernhard Welte. Meister Eckhart als Inspirationsquelle für Bernhard Welte und für die Gegenwart, LIT Verlag, Berlin, 2015., str. 103-118.

${ }^{540}$ Usp. MIETH D., isto, str. 103-118.

${ }^{541}$ Usp. ROESNER M., Logik des Ursprungs. Vernunft und Offenbarung bei Meister Eckhart, Karl Alber Verlag, Freiburg, 2017., str. 228.
} 
»samoodricanje ili odricanje od samog sebe« (Selbstverleugnung; Selbstentäußerung). ${ }^{542}$ Samoodricanje se ovdje, kako je već ukazao ovdje ma shvatiti u vidu pozitivnosti i sebenadilaženja autentičnost postojanja koje se (autentičnog) prema Eckhartu postavlja kao čovjeku nezaobilazni zahtjev. Eckhartu je tako posebno stalo do blaženstva koje se postiže jedino odricanjem od samog sebe, pri čemu se dotični koncept mišljenja kod Eckharta naziva intelektualnom askezom.

Kratak prikaz Eckharotve misli, imao je prvotno za cilj pokazati razlog Welteove fascinacije ovim njemačkim mističarem. Svakako, valja ukazati i na sljedeće: Welte ne slijedi „slijepo“ Eckharta već njegove temeljne postavke implementira u svoju filozofiju religije, poglavito u onom dijelu koji se tiče osobe. Samim time, Welte, takoreći nadograđuje i upotpunjuje Eckhartovu misao suvremenim postavkama slobode i dostojanstva pojedinca. Navedeni su pojmovi svakako, u temeljnim obrisima prisutni i kod Eckharta, pri čemu njemački teolog ove suvremene vrijednosti individue, tumači u bitnome $\mathrm{u}$ perspektivi čovjekova odnosa prema Bogu. Konačno, otvorenost prema životu kao takvom, jest odlika Welteova promatranja čovjeka općenito, te njegova odnosa prema Bogu posebno. Iz te otvorenosti nadolazi poštivanje slobode i time dostojanstva drugih s kojima živimo i jesmo na ovom ovozemaljskom putu života. Uz navedeno, nezaobilazna je evanđeoska kategorija Ljubavi (koliko god u suvremenosti zvučala prozaično), pri čemu iz ovog Ivanovskog krucijalnog definiranja Boga, (Bog je ljubav - „Tko ne ljubi ne upozna Boga jer Bog je ljubav“, 1Iv, 4,8), proistječe magna charta čovjekova života i djelovanja, u odnosu prema sebi, drugima i konačno samome Bogu. ${ }^{543}$ Kada kažemo magna charta, tada s Welteom ne mislimo toliko na zapovijed, već na lakoću, djetinju bezazlenost, štoviše, igru života. U tom se smislu čitav čovjekov život može se svesti pod vrlo lijepu Welteovu misao gdje on kaže kako je život igra nad kojom blista skriveni sjaj vječnog igrača koji se igra. ${ }^{544} \mathrm{U}$ tom smislu čovjeka više vodi ljubav spram života negoli strah koji mu se kroz život nameće i to je ona „hrabrost za strah“ koju Welte često spominje gdje se čovjek suočava sa životom i stvarnostima koje mu se nameću u okviru njegova postojanja, prevladava ih i hrabro nastavlja dalje voditi svoju vlastitu bitku života.

Upravo iz toga razloga potrebno je u nastavku govoriti o Welteovu poimanju vjere koja je „hrabrost za strah“ unutar njegove filozofije i fenomenologije religije te oblicima na

\footnotetext{
542 Usp. ROESNER M., Selbstenäußerung und Selbstverleugnung bei Mesiter Eckhart unter besonderer Berücksichtigung seines lateinschen Schriftwerks, u: Meister Eckhart und Bernhard Welte. Meister Eckhart als Inspirationsquelle für Bernhard Welte und für die Gegenwart, LIT Verlag, Berlin, 2015., str. 119-140.

${ }^{543}$ WELTE B., Filozofija religije, str. 234.

${ }^{544}$ Usp. WELTE B., Gesammelte Schriften I/1 Person, str. 288.
} 
koje čovjek provodi svoju vjeru (molitva šutnje, govora i kulta kao načini izvršenja same vjere).

\section{Pojam vjere u Welteovoj fenomenologiji religije}

Pojam vjere se provlači kroz svu Welteovu filozofijsku i religioznu misao. Misao o vjeri obilježava njegov bogati opus djela. U religioznom smislu pojam vjere je uvijek kvalitativno različit od pojma znanja, a napose se vjera razlikuje od modernog znanja današnjice koje karakterizira empirijsko-pozitivistički pristup znanju i znanosti. Bitan sadržaj vjere jest Bog, koji je nepojmljiv i neizreciv. U tom ga smislu nije ga moguće uspoređivati sa znanjem. Zbog toga je zahvaćanje neizrecivog i beskonačnog, jedinstvenog Boga drugačije od svake vrste potvrđivanja znanja i znanstvenih metoda.

Ondje gdje je čovjek pogođen Bogom, on ne može vjerujući u Njega ostati izvan razmatranja o Njemu i svojemu pristupu Njemu. ${ }^{545}$ Temeljni odnos čovjeka prema Bogu nema značajku sigurnosti niti nekog kontroliranog raspolaganja i ovladavanja svojim sadržajima, i u tom je smislu izvjesnost vjere različita od izvjesnosti znanja. Naime, vjera ima posla s onim neraspoloživim, dok znanje uvijek možemo verificirati. Vjera je uvijek osobna i slobodna odluka, ili osobno stanje koje proizlazi iz takve odluke te se u ponovljenim odlukama uvijek iznova obnavlja. ${ }^{546}$ Vjera nije vezana uz proizvoljnost iako, je jasno potpuno slobodna, i stoga nije subjektivna, a nije niti objektivna jer Tajnu s kojom je povezana ne posjeduje, na način drugih svojina nego se s jezgrom svoje osobnosti i svoje slobode čovjek upušta u tu tajnu i njome, kako je već istaknuto, biva pogođen. ${ }^{547}$ Slobodu, koju smo u prethodnom u bitnome povezali uz vjeru, u ovom smislu treba shvatiti kao nešto pozitivno jer predstavlja osobni polet i slobodno predanje.

Različiti su modeli vjere. Welte ih spominje nekoliko. Prvi od tih jest onaj gdje kvaliteta mora iskoračiti ponad kvantitete (npr. u pogledu nekog umjetničkog djela, gdje onaj koji se hoće približiti kvaliteti promatranoga mora napraviti iskorak). To je ono pozitivno pripadno osobnoj slobodi svakog pojedinca. Drugi model vjere jest onaj međuljudski. Welte ovaj model označava sa ono »ti« susreta. Za to je potrebna odvažnost samog susreta koji se

\footnotetext{
${ }^{545}$ WELTE, Filozofija religije, str. 158.

${ }^{546}$ Isto, str. 159.

${ }^{547}$ Usp. Isto, str. 159.
} 
može dogoditi samo slobodno pri čemu se osobito traži hrabrost osobnog povjerenja. ${ }^{548}$ Samo $u$ i kroz osobnu slobodu može izrasti osobni odnos, a cjelokupni tijek osobnog odnosa i osobne vjere se odvija unutar osobnog obzorja, unutar života svakog pojedinca. To je i model za pozitivnu osobnu slobodu, koja je pogođena Božjom tajnom, te na koncu postaje i živom ljudskom osnovom religiozne vjere. ${ }^{549}$ Kretanje vjere stoga uvijek se događa u okviru slobode. To kretanje Welte označuje kao zbiljsko događanje i poziva se na Kierkegaarda koji kaže kako onaj koji vjeruje mora svoju egzistenciju zbiljski i u ozbiljnosti unijeti u kretanje vjere. ${ }^{550}$ Vjera se prema Kierkegaardovim riječima mora smatrati više subjektivnim nego objektivnim elementom. Prema danskom filozofu vjera je subjektivna kakvoća individuuma, kojim se očituje ljubav prema Bogu. Tu ,ja“ individuuma stoji u odnosu s „Ti“ Boga. ${ }^{551}$ Tako on piše: „Religiozno nije javno, već nešto što pripada pojedincu; ako je religioznost zbilja, a ona to jest, onda svaki čovjek može i mora biti pojedinac. Za mene je kao vjerskog i pobožnog pisca upravo veselje govoriti o pojedincu. U mnoštvu, u javnosti, u društvu nestaje pojedinca, a on postaje vrijedan u individualnom odnosu s Bogom“. 552

Pouzdanje (njem. Verlassen) $)^{553}$ je vrlo bitno za vjeru, štoviše u židovsko-kršćanskoj perspektivi vjere, označeno kao presudno. Ono je oblik prepuštanja sebe Bogu. U vjeri se vjernik ozbiljno i zbiljski ispušta iz ruku svoje vlastite skrbi o samome sebi, iz svojeg vlastitog raspolaganja samim sobom, konačno vlastitog ustrajanja na samome sebi. ${ }^{554}$ Prepustiti samog sebe zbiljski i posve znači prepustiti sebe i cijeli svoj svijet tajni koja nadilazi sve ovozemno. Osim kroz pojam predanja, pouzdanje se u bitnome određuje upravo i u perspektivi Tajne. Ona mu, kao ono ne-do-kraja dokučivo i iskušano, daje karakter iskoraka, skoka. Samim time vjera, kroz predanje, nužno prelazi u pouzdanje ili jasnije nadu. Štoviše, prepuštajući se i potvrđujući Boga kao nedokučivu ali ipak blisku Tajnu, vjera dobiva značenje bezuvjetnog predanja. Da bi za to bio sposoban, čovjek mora vjerovati i u samog sebe. U tom smislu istinski vjerovati u Boga znači vjerovati u svoje darove i sposobnosti, iz Božje ruke prihvatiti sama sebe onako kako se jest. ${ }^{555} \mathrm{Na}$ taj način čovjek i samog sebe prekoračuje, pogled mu biva usmjeren kroz nadu u budućnost. Konačno, to „vjerujuće da“,

\footnotetext{
${ }^{548}$ Usp. Isto, str. 160-161.

${ }^{549}$ Usp. WELTE, isto, str. 161.

${ }^{550}$ KIERKEGAARD S., Philosophische Brosamen und Unwissenschaftliche Nachschrift, ur. Diem H. i Rest W., Köln-Olten, 1959., str. 460-480.

${ }^{551}$ KIERKEGAARD S., Die Schriften über sich selbst, ur. Hiersch E., Gütersloher Verlagshaus, Bad Birnbach, 1998., str. 9-10.

552 KIERKEGAARD S., isto, str. 9-10.

${ }_{553}$ Njemačka riječ sich verlassen $=$ pouzdati se.

${ }^{554}$ WELTE B., Filozofija religije, str. 163.

${ }^{555}$ Isto, str. 164.
} 
odgovor prianjanja čovjeka uz Boga znači i solidarnost s drugim ljudima, potvrđivanje, unaprjeđenje i u konačnici oslobađanje. ${ }^{556}$

Motiv čuda također je jedna od važnijih dimenzija vjere. Welte je bio mišljenja kako onaj koji vjeruje u Boga u svemu što ga susreće čeka iskustvo čudesnog. Ohrabrujuće obećanje onog u tom smislu čudesnoga ponekad se čovjeku daruje kao iskustvo da je čudesno nošen $\mathrm{i}$ zaštićen i u sjeni noći i smrti, ili kao dar spasa i iscjeljenja, u smislu koji nadilazi svako nadanje. ${ }^{557}$ Upravo to je korijen čuda u najširem smislu. Na mnogim mjestima u povijesti tamo gdje je vjera živjela, pripovijedalo se i o čudesima. Iskustvo čudesnog često biva slikovito opisano u pripovijestima, koje zapravo predstavljaju pravo vjersko iskustvo. No, Welte je s pravom upozorio i kako se vjera može iskvariti u tom odnosu prema čudu i čudesnom. Ona nikada ne smije postati nekakva otuđujuća svrha koja bi raspolagala Bogom radi svojih vlastitih ciljeva, jer u tom slučaju proklizuje direktno u magiju, što je pak suprotnost vjeri. ${ }^{558}$ Magija po sebi nema za učinak nikakvo čudo, već veću ili manju sposobnost uvjeravanja to jest obmanjivanja da se nešto izvanredno dogodilo ili događa. Ne bi se, međutim, trebao steći dojam, da Welte u potpunosti rastavlja pojam vjere od pojma čuda. Prijemosnica ovih dvaju pojmova kod njega je ,čudesnost““. Čudesnost, je za razliku od čuda, istovremeno i očigledna i tajnovita, te u bitnome dodiruje divljenje, a ne strah. Pogotovo ne prisilu da se u njega vjeruje. Upravo se zbog toga, prema Welteu, na putu zbiljske vjere događa ono istinski čudesno. Čudesno, primjerice u pogledu obraćenja! Svakako, niti pojam čuda kao takvog, Welte ne želi odvojiti od vjere kao niti od cjelokupnog reda i susljednosti uspostavljenog od Apsoluta. No, temeljna je poanta da čudo upravo ne ovisi o ljudskoj, već Božjoj slobodi, to jest volji. Tako je primjerice Toma Akvinski primijetio kako u čudu Bog ne uklanja potpuno poredak svemira, od čega se sastoji njegova dobrota, nego samo poredak jednog osobitog uzroka i njegova učinka (De. Pot. VI, a. 1, ad 7) te se pobrinuo za točno razlikovanje načina kojima Bog čini čuda u prirodi. ${ }^{559} \mathrm{O}$ nadnaravnom činu može se govoriti kada učinak što ga je Bog proizveo, priroda ne može proizvesti ni na koji način; o protunaravnom činu kada u prirodi ostaje ustroj protivan učinku što ga Bog proizvede; te o vrhunaravnom činu kada Bog ostvaruje čin koji bi mogla ostvariti i priroda, no na način koji je za nju nemoguć. ${ }^{560}$ Posebno je zanimljiv Welteov suvremen način i prikaz razmišljanja o čudu, koje je prema njemu, bitni sastavni element vjerovanja u Božju opstojnost, jer upravo $u$

\footnotetext{
556 Isto, str. 165.

557 Isto, str. 168.

${ }^{558}$ Isto, str. 169.

559 AGUTI A., Filozofija religije. Povijest, teme, problemi, KS, Zagreb, 2017., str. 262.

${ }^{560}$ Isto, str. 262.
} 
i kroz čudo se Bog potvrđuje kao samoinicijativno biće, kao trajni darovatelj i slobodni stvaratelj svijeta, koji pak, nije vezan ni uza kakve zakone te im, u tome smislu, ne podliježe. Kada to ne bi bilo tako, mogli bismo reći kako bi Bog bio tek plod nekog ljudskog umišljaja. No, Welte napominje i kako autentični vjernik mora stalno bdjeti da vjeru u Božja čuda ne bi izopačio u ljudsku lakovjernost prema magiji i sklonosti ka istoj. ${ }^{561}$

Čovjek je za Weltea izvršitelj religije (Der Mensch als Vollbringer der Religion). ${ }^{562} \mathrm{U}$ religijskoj filozofiji se prvotno govori o Bogu jer svaka prava religija biva određena od Boga. No, uz govor o Bogu, ide i govor o čovjeku unutar pojedine religije. Ovdje treba imati na umu kako sva Welteova razmatranja se uvijek tiču i polaze od kršćanske religije kojoj je pripadao i s kojom je bila usko vezana i prožeta sva njegova misao. Na vidjelo izlazi cjeloviti odnos Boga prema čovjeku, te čovjeka prema Bogu, iako se o čovjeku do sada govorilo samo usputno, međutim, upravo sada do izražaja dolazi ovaj cjeloviti i izravni odnos Boga i čovjeka. Jer religija je, kako to Welte kaže, upravo cijeli taj kontekst, u kojem je čovjek u vezi s Bogom, jednoj i Bog priziva čovjeka i određuje njegovo ponašanje dajući mu slobodu, $\mathrm{s}$ druge strane. ${ }^{563}$

Stoga, kada se govori o religiji i Bogu, tada moramo govoriti i pažnju obratiti na čovjekovo religiozno ponašanje. Samo ondje, gdje Bog kao takav određuje ljudsko ponašanje, možemo govoriti o religiji u punom smislu te riječi, jer Bog i čovjek su neodvojivi, pri čemu je svakako, valja to imati na umu, pojam o Bogu, prema Welteu, temelj religije. ${ }^{564}$ Autor S. Kušar će reći sljedeće vezano uza misao o Bogu: „Misao o Bogu valja naime smatrati prvom i temeljnom pretpostavkom objave i vjere - ako se Bog niječe, onda je time direktno pogođena mogućnost objave i njezino razumijevanje. Tako se misao o Bogu pokazuje središnjom točkom od koje trebaju poći sva nastojanja filozofije koja se razvija u usmjerenju prema vjerovanju. U okviru suodnosa između filozofije i teologije misao o Bogu i pitanje o Bogu je mjerilo zatvara li se neki oblik filozofiranja u svojoj samodostatnosti ili pak uočava i tematizira sam od sebe svoje granice priznavajući da ne može izbjeći pitanje o Bogu i upravljenosti čovjeka prema apsolutnome, koliko god to inače bilo moguće potisnuti iz

\footnotetext{
${ }^{561}$ Usp. WELTE B., Filozofija religije, str. 157.

562 Isto, str. 157-168.

${ }^{563}$ Usp. Isto, str. 157.

${ }^{564}$ Usp. Isto, str. 157. Izričaj iznijet u tekstu 'o Bogu koji kao takav određuje ljudsko ponašanje', može voditi prema pogrešnom zaključku, naime, da religioznost (Bog) ništi ljudsku slobodu. U tom smislu, pojam „određuje ljudsko ponašanje“ ovdje se ima shvatiti u krajnje određenom smislu s obzirom ,čovjekovo izvršenje religije“. Njega naime, jer mu je prvotni motiv te sama okosnica (Bog), uvjetuje upravo jedan (božanski to jest od čovjeka različit) Bog.
} 
vlastitog filozofskog vidokruga“. ${ }^{565}$ Čovjek vjernik svoju upućenost prema Bogu kao tajni uvijek proživljava na različite načine i kroz vjeru kao okosnicu svoga života.

Iz toga razloga se Welte u svojim razmatranjima pita o religijskim stajalištima koja čovjek gaji spram Boga, među kojima se naglasak posebno stavlja na vjeru i molitvu, o kojima će biti više riječi u nastavku rada. Svi problemi koje Welte donosi to jest iznosi na vidjelo ne tiču se samo teologije, već bivaju usko vezani i za područje filozofije i znanja. Postmetafizičkog Boga Welte naziva božanskim Bogom ${ }^{566}$. On izaziva u čovjeku religiozno ponašanje, a razumijevanja Boga na ovaj način počiva uvijek na izvornim iskustvima koja se kroz vjeru očituju i produbljuju.

\subsection{Molitva šutnje, govora i kulta kao načini izvršenja religije u filozofiji Bernharda Weltea ${ }^{567}$}

U svojoj filozofiji religije Welte je osobitu pozornost posvetio razmatranju onog što on naziva ,izvršenje religije“. Budući da je to izvršenje, između ostalog, potaknuto i čovjekovim traganjem za smislom, prilog započinje Welteovim ukazom o nerazdruživoj vezi smisla i religije. Time se pak nužno dolazi do pojma Boga jer je On nositelj smisla. Na tragu njemačke mistike te posebno M. Eckharta, Welte se usteže Boga podvrgnuti svakoj kategorijalnosti, te Ga slijedom toga, označava pojmovima neizrecivi, beskonačni, skriveni. Kao onaj koji je neizreciv i skriven, Bogu se pristupa putem molitve i njenih oblika odnosno oni bivaju autentični načini čovjekova odnošaja prema Bogu: time smo došli do središnje komponente ovog dijela rada, koja je sadržana u predstavljanju temeljnih aspekta welteovskog viđenja molitve - molitva kao šutnja, kao govor i kao kult. Svaki od ovih pristupa sadrži svoju osobitost: molitva šutnje nikako nije negacija govora; molitvu govora pak u bitnome karakterizira dvo-polnost, dok u kultu na poseban način do izražaja dolazi pojam zajednice i s njom okupljalačka dimenzija govora. Također, u obzir se moraju uzeti i opasnosti u koje izvršavanje religije s obzirom na molitvu i kult može skliznuti. To, kako ga njemački filozof naziva, izopačenje religije, predstavlja stari, a uvijek novi problem svake religije: „Ovaj me

\footnotetext{
${ }^{565}$ KUŠAR S., Spoznaja Boga u filozofiji religije. B. Welte i božanski Bog, str. 59-60.

${ }^{566}$ KUŠAR S., isto, str. 60.

${ }^{567}$ Ovaj dio doktorskog rada (str. 55-68) prihvaćen je za objavljivanje i biti će objavljen u časopisu Diacovensia 28 (2020) 4, kao izvorni znanstveni rad što je bio jedan od uvjeta koje je potrebno ispuniti u doktorskom studiju filozofije.
} 
narod časti samo usnama, a srce mu je daleko od mene." O navedenom će izopačenju svakako biti riječi u nastavku razmatranja molitve kao takve u Welteovom smislu.

Kako je već istaknuto, središte filozofije religije je Bog kao stvarnost to jest očitujući fenomen po religiji u svijetu. On se kao stvarnost u filozofsko-fenomenologijskom smislu kroz ljudski život očituje na razne načine. Početni je vid, misao o Bogu koja je time presudna pretpostavka i temelj religije. ${ }^{568}$ Religija je određena Bogom, međutim, kao što je ona određena Njime, tako je i kroz govor o Bogu potrebno govoriti o onome koji taj govor upućuje. Riječ je o čovjeku. Čovjek je taj i jedino biće koje promišlja, govori i djeluje kroz kult s obzirom na Boga. Religija je, u izvjesnom smislu, čitav sklop međusobnog djelovanja, u kojem se čovjek odnosi prema Bogu, na jednoj i u kojem se Bog čovjeku objavljuje kroz znakove i simbole te određuje njegovo ponašanje, na drugoj strani. ${ }^{569}$ Kada se na ovaj način govori o religiji tada pri tome treba imati na umu čovjekovo religiozno ponašanje uopće. Pritom su njegova vjera, molitva i kult temeljni oblici religije. To su ljudski načini ponašanja koji na mnogostruk način proizlaze iz pretpostavke misli usmjerene na Boga i iz načina kako se Bog čovjeku očituje i suočava ga sa svojim zahtjevom. ${ }^{570}$ Svakako, molitvi i kultu u pozadini mora biti upravo vjera, koja se, u autentičnom smislu, ima uzeti kao conditio sine qua non čovjekova odnosa prema Bogu. U isto vrijeme, vjera je prema Welteu, humana osnova religije. ${ }^{571}$ Pojam 'humana' njemački filozof shvaća u specifičnom smislu, to znači ne u strogoj ćudorednosti na koju ovaj pojam u svojem temeljnom značenju smjera. U religiji, naime, čovjek, doživljava samoga sebe kao onoga koji je Bogom određen na način povjerenja te upravo iz te „uvjetovanosti“ i ,intime“ uspostavlja ovaj odnos, uviđajući istovremeno, da se radi o odnosu osobe prema osobi. Zbog toga upravo ima humani karakter. ${ }^{572}$

U tome smislu Welte najprije predstavlja nacrt prvog puta prema Bogu kao bitnoj pretpostavci religije, koji ne želi biti dokaz za Božju opstojnost ni u tradicionalnom smislu ni u smislu egzaktne znanosti, nego u smislu puta na kojem vjernik može osmisliti svoju vjeru i govor o Bogu. ${ }^{573}$ Njemački se filozof u tom smislu oslanja na M. Heideggera koji smatra da Bog koji je takvim dokazima postavljen kao siguran, nije božanski Bog. ${ }^{574}$ Moderna znanost

\footnotetext{
${ }^{568}$ Usp. WELTE B., Filozofija religije, str. 83.

569 Isto, str. 157.

${ }^{570}$ Isto, str. 157.

571 Isto, str. 158.

${ }^{572}$ Isto, str. 53.

${ }^{573}$ Welte ovdje spominje Hansa Alberta i njegov kritički racionalizam koji je na Kantovu tragu. U tom smislu nisu mogući nikakvi znanstveni dokazi za Božju opstojnost.

${ }^{574}$ HEIDEGGER M., Die onto-theologische Verfassung der Metaphysik, u: Identität und Differenz, Pfullingen, 1957, 35-73. i Brief über den Humanismus, Frankfurt a. M., 1949., str. 313-364.
} 
ne može dati dokaze za Božju opstojnost. Govoriti o našem opstanku u svijetu ima smisla samo ako pritom s time shvatimo i to da tom opstanku pripada otvorenost iskustva, Božjeg i našeg. ${ }^{575}$

$\mathrm{Na}$ tom tragu, Welte daje nacrt drugog puta prema Bogu, pri čemu je u središtu pozornosti Leibnizovo ${ }^{576}$, Schellingovo i Heideggerovo temeljno metafizičko pitanje zašto jest biće, a ne radije ništa. Naime, čovjeku je jasno da nekada nije postojao, te mu se zbog toga nameće pitanje zašto onda uopće jest, koje pak sobom povlači daljnje pitanje zašto svijet uopće jest? A na to pitanje prirodne znanosti ne mogu dati konkretan odgovor jer se tu javlja tajna onoga već spomenutog „ništa“ kao zagonetnog, tajnovitog, bezuvjetnog i beskonačnog temelja svega što jest, koja pak nije stvar prirodoznanstvenog istraživanja, nego slobodne odluke za smisao. Doduše, znanost ne treba hipotezu Boga, ali ta hipoteza ne gubi svoju relevantnost u kontekstu tajnovitosti sveukupne stvarnosti. Štoviše, Welte smatra kako hipoteza Boga nije uopće potrebna da bi se mogao objasniti svijet i njegov tijek, a niti za to da bi se njime moglo tehnički ovladati. To se još uvijek događa »etiam si Deus non daretur« kao da Boga nema. ${ }^{577} \mathrm{U}$ tom sklopu valja čitati Wittgensteinov izričaj da se Bog u svijetu ne objavljuje. ${ }^{578}$ Znanost se kreće na području empirijskog svijeta i (konačne) logike, ali nije besmisleno tvrditi da taj svijet i logiku utemeljuje beskrajna Tajna, da ona »koja sve nosi i odlučuje ujedno nosi i odlučuje logiku svega«.

S obzirom na rečeno, postaje jasno da je smisleno prihvatiti svoju konačnost na jednoj, te da nije besmisleno tragati za beskonačnošću, ispunjenu tajnom na drugoj strani. Traganje za smislom je štoviše »ispunjeno živim interesom našeg opstojanja«, te se nameće svojevrsnom nužnošću postojanja, postavljanja pitanja i davanja odgovora. Budući da je ono angažirano, mi ne samo da pitamo o smislu, nego i redovito djelujemo u tom pogledu. Traganje za smislom, nadalje, ne može biti samo privilegija racionalnog opravdanja vlastita postojanja, kao i svijeta u kojem opstojimo. Pitanje smisla s obzirom na ono „religiozno“ $u$ i kod čovjeka, pokazuje da je život sam po sebi (a ne samo Bog) ispunjen tajnovitošću i

\footnotetext{
${ }^{575}$ Usp. WELTE B., Filozofija religije, str. 55.

${ }^{576}$ Leibniz je prvi, na izričit način, formulirao ontološko pitanje postojanja: zašto postoji upravo to nešto?, zašto je to što postoji upravo ovakvo?, zašto ja postojim?, zašto mi postojimo? Usp. LEIBNIZ G. W., In der Vernunft begründete Prinzipien der Natur und Gnade, u: LEIBNIZ G. W., Philosophische Schriften, prev. Holz H., sv. I., Kleine Schriften zur Metaphysik, Darmstadt, 1965., str. 414-439 i 427.

577 To je metodičko polazište novovojekovne znanosti koja tamo to jest u područjima gdje je ovladala cjelokupnim opstojanjem života, na kraju postaje nesposobna uopće postaviti pitanje o Bogu. O tome govori, kako i sam Welte navodi, BERNHARD C., u djelu: Die Unfähigkeit zur Gottesfrage im positivistischen Bewußtsein, Herder, Freiburg, 1972., str. 27-42.

578 WELTE B., Filozofija religije, 83. i WITTGENSTEIN L., Tractatus logico-philosophicus s uvodom Bertranda Russela, prev. Petrović G., Veselin Masleša - Svjetlost, Sarajevo, 1987. str. 150.
} 
nedovršenošću. Čak su odricanje od smisla i odluka za besmisao mogući samo zato što se takve odluke, u vidu stavova i djelovanja, pokazuju, za nekog, kao smislene. Stoga se može reći da vjera u beskonačnu i „bezuvjetnu“ moć, koja svemu čuva smisao i o svemu odlučuje, može biti smisleno, pa i razumski utemeljena vjera. ${ }^{579}$

Upravo taj vid, potraga za smislom te vjera u „bezuvjetnu“ moć očituje utemeljenost religioznih čina, odnosno očituje potrebu molitve i kulta, što znači izvršenja same religije. (Straho)poštovanje prema Svetomu, kao odlika svake religije i religioznosti, u najdubljoj se osnovi stavlja nasuprot onog sigurnog, to jest dokazanog i provjerenog, sa svih strana „,iskušanog“ i spoznajno „konzumiranog“. Izvršenje religije, u molitvi, kao šutnji na jednoj, i riječi na drugoj strani te kultu općenito, smjera prema beskonačnom i bezuvjetnom koje, prema Welteu (i njegovom uzoru Eckhartu) nije ni biće ali ni ništa, nego apsolutna Tajna, koja se upravo zbog toga može nazvati Bogom te u konačnici zaslužuje navedeno (straho)počitanje. ${ }^{580}$ Pri tome ovo izvršenje u svojim oblicima šutnje, govora i čina, očituje u isto vrijeme potragu za smislom.

\subsection{Oblici molitve i njihova važnost u Welteovoj filozofiji religije}

Zazivanje i molitva pripadaju osnovama religioznog ponašanja, tako da pitanje o Božjoj osobnosti dotiče i pitanje temelja religioznih čina. ${ }^{581}$ Božje boštvo za naše iskustvo temelji se u događajima objave i stoga ima poseban povijesni značaj. Vječna tajna u svojoj epifaniji premašuje temeljnu razliku između nad-bića i bića te se tako daje u obrisima $u$ poretku bića. ${ }^{582}$ Povijest, religija, najbolje svjedoči povijesnom mijenjanju Božjeg lika prema vremenu i prostoru te čovjekova pokušaja prodiranja u ovu Tajnu. Upravo je čovjek onaj koji se oslanja na Boga, potvrđuje ga, priznaje i u konačnici mu se obraća. Taj način čovjekova obraćanja Bogu odnosno to, Welteovim riječima, izvršenje života, koje se događa u obraćanju Bogu, nazivamo upravo molitvom. ${ }^{583}$ Čovjek koji je vjernik ujedno mora biti i čovjek molitve, jer je to temeljni način ophođenja s Bogom. U tom smislu Welte dojmljivo ističe, kako je vjera korijen religioznog života, a molitva mu je cvat te ako vjera predstavlja temelj, molitva $\mathrm{u}$ isto vrijeme predstavlja izvedbu. ${ }^{584}$ Njemački je filozof religije svjestan da se

\footnotetext{
${ }^{579}$ Usp. WELTE B., Filozofija religije, str. 71.

${ }^{580}$ Usp. Isto, str. 56-63.

${ }^{581}$ Usp. Isto, str. 135-141.

582 Usp. Isto, str. 135.

583 Usp. Isto, str. 170.

${ }^{584}$ WELTE B., Filozofija religije, str. 170.
} 
molitva pokazuje $u$ i $k r o z$ različite oblike pozivajući se pri tome na Friedricha Heilera. ${ }^{585}$. Ono što je potrebno prilikom govora o molitvi jest razlučiti bitne od njenih nebitnih oblika. Bitnu molitvu spoznajemo kada uvidimo da je primjerena kako tajni Boga tako i tajni čovjeka, pri čemu je zapravo, sama molitva također tajna. ${ }^{586}$ Stoga je potrebno razmotriti najvažnije oblike molitve, koji su prema Welteovu tumačenju sljedeći: molitva šutnje, molitva kao govor i molitva kao kult. ${ }^{587}$ Oni su predmet naših razmatranja.

\subsection{Molitva šutnje}

Molitvu šutnje označavamo kao onu najmanje izražajnu, jer kako sam naziv govori, ona se odvija u šutnji i s njom pripadajućoj tišini, pri čemu koji se Bogu tako obraća ima u vidu neizrecivost i nedokučivost tajne koja ga nadilazi. Molitva šutnje je najautentičnije priznanje ove nedokučivosti. Čovjek svoju riječ zadržava u šutnji. Nijema je šutnja stoga prvi lik molitve, i u njoj se smrtni čovjek najprimjerenije odnosi prema Bogu, prvoj i vodećoj odrednici svake religije. ${ }^{588}$ Ovakav oblik molitve, molitva šutnje, bio je često opisivan u zapadnoj kršćanskoj tradiciji, napose u mistika. Meister Eckhart ovdje služi kao eklatantni primjer. Welte također spominje i jednu od najvećih svjetskih religija, budizam ${ }^{589}$, koji

${ }^{585}$ HEILER F., Das Gebet: eine religionsgeschichtliche und religionspsychologische Untersuchung, München, 1920., 300-350.; WELTE B., Filozofija religije, str. 170.

${ }^{586}$ WELTE B., Filozofija religije, str. 170.

${ }^{587}$ Welte tumači izraz der Kult, kao onaj koji označava sveukupnost čina kojima se iskazuje štovanje Bogu; za razliku od bogoslužja (liturgije), koje ima uže značenje glavnih bogoštovnih čina (služba Božja). U hrvatskom kult pokriva značenje bogoštovlja i bogoslužja bez razlike. Osim u rijetkim iznimkama i zbog stilskih razloga ovdje Welte ne rabi te izraze, jer im je značenje isključivo vezano uza monoteističke religije, u prvom redu uz kršćanstvo, i jer se uobičajeno koriste u kršćansko teologijskom kontekstu, dok je ovdje bitan kontekst religijsko-filozofijskog razmatranja.

588 WELTE B., Filozofija religije, str. 172.

589 Budizam je religijski sustav nastao u Indiji u VI. i V. st. pr. Kr. (oprečan vladajućemu brahmanizmu), osnovan na učenju Siddhārthe Gautame. Glavni sadržaj učenja (dharma) tvore »četiri plemenite istine« (catvari ärya satyāni) o patnji, nastanku patnje, prestanku patnje i oslobođenju od patnje. Život je patnja (duhkha), uzrok su patnji želja (volja, žeđ, tṛ̌ṣnă) i neznanje (avidyā), koji stalnim nemirom, kao načelom uzročnosti (karman), određuju sudbinu svakoga čovjeka i stvaraju neprekidni krug rađanja i smrti (samsāra), to jest ponovnih utjelovljenja, koja su opet patnja. Čovjek se toga može osloboditi postizanjem nirvāne (utrnuća, ugasnuća), to jest odvraćanjem od svega što vezuje uz život. Tomu vodi »osmeročlani put« (ašțāńga mārga), to jest prava vjera, prava odluka, pravi govor, pravo djelovanje, pravo življenje, prava težnja, pravo mišljenje i prava usredotočenost. Čovjek je, prema budizmu, tek privremeni zbir pet nakupina (skandha): oblika ili fizičkoga tijela (rūpa), osjećaja (vedanā), percepcije ili razumijevanja (samjña), volje (samnskāra) i čiste svijesti (vijñāna). Njihove su značajke rođenje, starost, smrt, trajanje i mijenjanje; bez esencije su (anātman), bez stalnosti (anitya), prazne (šünya) i obilježene patnjom (duhkha). Budizam pitanje supstancije i duše smatra iluzornima, pa se katkad i određuje kao religija bez boga ili bez duše. Budizam se suprotstavlja vladajućemu brahmanizmu nepriznavanjem kasta, obreda $\mathrm{i}$ askeze, a žrtvovanju životinja pretpostavlja samilost, strpljivost i samoodricanje, u: BROZOVIĆ D., KOVAČEC A., RAVLIĆ S., Hrvatska enciklopedija, mrežno izdanje. Pristupljeno 20. 6. 2020. Dostupno na: https://www.enciklopedija.hr/natuknica.aspx?ID=9995 
upravo svoju religioznost živi posve iz molitve šutnje. Neke od karakteristika molitve šutnje su: negativnost šutnje kao odijeljenost, pozitivnost šutnje kao sabranost, pozitivnost šutnje kao pobožnost te obrat (molitvene) zahvale u šutnji, čime se postiže cjelina.

Prva karakteristika molitve šutnje je, kako je spomenuto, da je ona negativna. Negativna je u smislu da predstavlja izuzimanje od svega što karakterizira današnji život prepun jurnjave i raznog govorkanja. Ona se ne bavi ničim i ne dati se ni od čega natjerati u puko isprazan govor. Ona predstavlja tišinu duha, što je zapravo druga riječ za cijeloga čovjeka. ${ }^{590}$ Kroz negativnost šutnje čovjek pušta da utihnu nagoni i opsjednutost svijetom kao i njegova znatiželja te postaje tišina i opuštenost. Kao primjer, Welte ovdje, ponovno uzima M. Eckharta koji govori o tomu da čovjek mora postati jednak onomu ništa. ${ }^{591}$

Kao druga karakteristika molitve šutnje, očituje se pozitivno prešućena pozitivnost. Ona je najprije pozitivnost spremnosti; to je kao čisto slušanje, koje doduše ne čuje nikakvo konkretno nešto, ali je otvoreno i spremno čuti sve. Iz pozitivnosti proizlazi sabranost, sabranost iz raspršenosti ovog svijeta. Ona pri tome nije bez svijeta ili odijeljena od svijeta, što prije svega znači kako nije zapala u svijet. ${ }^{592}$ Posebnu vrijednost riječ sabranost dobiva u religioznom smislu. U tihom prostoru šutljive spremnosti sve je sabrano, sav vanjski i sav unutarnji svijet, sve diše u tomu „sabrano“ i s njim u onom slobodno. ${ }^{593}$ Međutim, sabranost ima i antropološku kategoriju. Ključni pojam do kojeg Welte u prikazu sabranosti dolazi jest zapravo sloboda. Radi se o najizvornijem smislu slobode, o slobodi duha, pri čemu je u (šutljivom) sabranju na djelu sebe-sabiranje, sebe-objedinjavanje. Sabranost je, dakle, u kontekstu slobode u Welteovom smislu jedno više stanje smirenosti, kako unutarnjeg, tako i vanjskog svijeta. U tom se smislu ova sabranost i s njom povezana smirenost očituju kao uvjet istinske slobode, koja je za Weltea čista otvorenost. Iz te čiste slobode i otvorenosti, ova sabranost (čovjek), kao njen uvjet, obuhvaća sav svijet, ali ga ujedno i bitno nadilazi. ${ }^{594}$

Treća karakteristika molitve šutnje jest pozitivnost šutnje kao pobožnost. Riječ pobožnost između ostalih odredbi pripada religioznom jeziku i kao takva se i upotrebljava. U

\footnotetext{
590 WELTE B., Filozofija religije, str. 173.

${ }^{591}$ ECKHART M., Die deutschen und lateinischen Werke, u: Die Deutschen Werke, prev. Quint J., sv. 1., Stuttgart, 1958., str. 107. Pojam ništa u kontekstu molitve šutnje, ovdje ima za cilj ukazati na zahtjev smiraja koje je analogno umiranju: pasivnost kao primalačka kategorija.

${ }^{592} \mathrm{Na}$ ovom mjestu Welte spominje još jednog autora, Franza von Baadera koji za sabranost, koja biva slobodna od svijeta, govori kako je to ista ona koja nije zapala u svijet. Usp. također: STRAUSS DANIEL F. M., Intellectual influences upon the reformational philosophy of Dooyeweerd, Philosophia reformata, 69 (2004) 1, str. 151-181.

${ }^{593}$ WELTE B., Filozofija religije, str. 174.

${ }^{594}$ Isto, str. 174.
} 
Hegelovoj filozofiji religije ta riječ je igrala značajnu ulogu. ${ }^{595}$ Riječ Andacht ${ }^{596}$, označava čovjekovu usmjerenost ka Bogu kroz vrijeme, kao i formu života koja se u toj usmjerenosti oblikuje: pobožan je onaj koji je po Božjem, jer se sav pruža Bogu; odatle onda po-božnost, dakle, po Božjem, kao stav, držanje i odgovor Bogu, koji je prethodno na način objave oslovio čovjeka. ${ }^{597}$ Welte je mišljenja kako se upravo u pobožnosti ispunja molitva šutnje. Tek $u$ tomu ona je potpuna molitva i molitva u punom smislu. $U$ tranzitivnosti živog odlaženja od sebe i prelaženja onom vječnom nalazi se ono cijelo i ono najviše. ${ }^{598}$ To pogađa čitav čovjekov život i cjelinu njegova opstanka. Ova cjelina u sebi ima određeni okret koji Welte naziva obrat zahvale i krug religije. Tek u tom okretu ispunjava se cjelina i ono najviše što pripada molitvi. Kada bi molitva šutnje govorila, mogla bi reći sljedeće: „Ti si me darovao meni i sada mi, u trenutku molitve, daruješ to da se ja darujem tebi i to je okret, okret živi bez govora i prisutan je u šutnji “. ${ }^{599} \mathrm{O}$ pobožnosti religioznog čovjeka se može reći kako je to jedan živući cirkularni proces jer pobožnost kao kretanje uvijek odgovara izvornijem kretanju koje joj je već oduvijek izišlo u susret. Ona izvršava i su-izvršava ono što se izvršava po sebi i što se oduvijek već izvršilo polazeći od onog vječnog »Ti«. ${ }^{600}$ To Hegel naziva ono spekulativno u pobožnosti, sraz različitih kretanja u pobožnosti, koji ako se razumije u pogledu molitve šutnje, daje nam spoznati njezinu vrijednost i životnost. ${ }^{601}$ Kao stav, pobožnost sobom nužno uključuje vrlinu poniznosti koja je uvijek ,zahvalna“ za ono što ima i što prima. U tom smislu, događa se spomenuti molitveni (obrat) zahvale u šutnji: nikakve riječi ne mogu obuhvatiti zahvalnost, koju pobožan čovjek doživljava prema Bogu zbog primljenih darova. Pobožan čovjek zbog toga ostaje „zapanjen“ zbog veličanstvenih Božji darova, tako da šutnja „najbolje“ o kakvo se darovanosti radi. Time se, kako je natuknuto, u molitvi šutnje, postiže cjelina.

\footnotetext{
${ }^{595}$ HEGEL G. W. F., Vorlesungen über die Philosophie der Religion I/1, ur. Lasson G., Hamburg 1966., 235240.

${ }^{596}$ Andacht se rabi u njemačkom jeziku za pojam pobožnosti.

${ }^{597}$ WELTE B., Filozofija religije, str. 175.; opaska prevoditelja, S. Kušar.

598 Isto, str. 175.

599 Isto, str. 176.

${ }^{600}$ Isto, str. 176.

${ }^{601}$ HEGEL G.W.F., Vorlesungen über die Philosophie der Religion I/1, str. 240.; WELTE B., Filozofija religije, 176.
} 


\subsection{Molitva govora}

Molitva je šutnje velika, ali ona uvijek ostaje unutar granica ljudske mogućnosti. Unutar te granice nalazi se i molitva kao govor. ${ }^{602}$ Religija i molitva su ljudski oblici ponašanja, u njima se čovjek odnosi prema Bogu, stoga ni molitva kao govor ne može izostati. ${ }^{603}$ Welte će kazati kako tek kroz govor naš opstanak dostiže svoju puninu, primjerenu jasnoću i čvrstoću. ${ }^{604}$ Šutnja i tišina, u izvjesnom smislu, također pripadaju molitvi govora. Radi se o tijeku misli. Bog nas kao ljude pogađa u cjelini i sve dimenzije našega bića. U tom smislu, kroz molitvu govora se razvija naša komunikativna bit jer moleći, na način koji god, govorimo Bogu, obraćamo mu se. U molitvi kao govoru ljudi se obraćaju, govore Bogu i s Bogom, Bog biva imenovan i oslovljen i čovjek mu se povjerava. ${ }^{605}$ Ako je Bog imenovan, ako se molitva zbilja izgovara, onda tajna Boga ima svoju jasnu prisutnost u zajedništvu ljudi. ${ }^{606}$ Šutnja i njezina pobožnost kao unutarnja dimenzija molitve, te govor kao vanjsko izražavanje unutarnjosti uvijek pripadaju zajedno. O religioznom jeziku, molitvi kao govoru, Welte spominje mnoge publikacije koje su nam pokušale približiti tu stvarnost. ${ }^{607}$ Kada se radi o govoru općenito, njem. se filozof referira na autore poput Liebrucksa i Caspera te dodaje kako se u diskursu o govoru i govornicima u novijoj jezično-analitičkoj literaturi govori češće o trosmjernoj semantičkoj relaciji koja predstavlja relaciju prema govorniku, prema slušatelju te prema stvari o kojoj se govori. ${ }^{608} \mathrm{Za} \mathrm{razliku} \mathrm{od} \mathrm{toga,} \mathrm{u} \mathrm{molitvi} \mathrm{se} \mathrm{radi} \mathrm{o}$ svojevrsnoj dvo-polnosti. Ona s jedne strane ima teološki pol, dok s druge antropološki. Teološki pol jer govori Bogu, a antropološki jer čovjek koji govori Bogu. Ovdje iščitavamo relacijski značaj molitve kao takve, koja je uvijek upravljena prema Bogu, te jednostavno predstavlja intimni odnos čovjeka prema Boga.

Povrh rečenog, valja spomenuti da molitva dotiče i negativan govor koji zapravo vodi ka tome da negacijama riječi u molitvi uzveličamo onoga komu se obraćamo, Boga. Ako je

\footnotetext{
${ }^{602}$ Njem. die Sprache je korelat šutnji, prevodimo je kao govor i kao jezik. Govor u smislu sustava znakova pomoću kojih se odvija komunikacija između ljudi. Jezik pak kao najopćenitiji sustav znakovnog, glasovnog, pismenog izražavanja.

${ }^{603}$ WELTE B., Filozofija religije, str. 177.

${ }^{604}$ Isto, str. 177.

${ }^{605}$ Isto, str. 179.

${ }^{606}$ Isto, str.178.

${ }^{607}$ SCHILLEBEECKX E., Glaubensinterpretation. Beiträge zu einer hermeneutischen und kritischen Theologie, Mainz, 1971., str. 376-379.; EBELING G., Einführung in die theologische Sprachlehre, Mohr Siebeck Verlag, Tübingen, 1971., str. 264.; CASPER B., Sprache und Theologie. Eine philosophische Hinführung, Herder, Freiburg i.Br., 1975., str. 87.

${ }^{608}$ WELTE B., Filozofija religije, str. 179.; LIEBRUCKS B., Sprache und Bewußtsein, sv. 1, Akademische Verlagsgesellschaft, Frankfurt a. M., 1964., str. 218.; CASPER B., Sprache und Theologie. Eine philosophische Hinführung, str. 87.
} 
Bog oslovljen kao beskonačan, kao bezuvjetan i neizreciv, onda se upravo negacijama tih riječi ukazalo na tajnu koja je veća od svih riječi. Jezičnim oblikom negacije jezik transcendira svoje vlastite granice, granice svoje konačnosti. ${ }^{609}$ Druga jezična mogućnost molitve jest oslovljavanje, to jest imenovanje Boga u afirmacijama što predstavlja pozitivnosimbolični govor. U njoj se Bog pozitivno imenuje u simbolima. Te pozitivne riječi imaju funkciju simbola, što znači da u njima značenja 'padaju zajedno' (što simbol i predstavlja, znači). Upravo je simbolički govor „najzahvalniji“ u pristupu k Bogu jer s jedne strane simbol može iskazati pozitivnu konačnu riječ $\mathrm{i}$ ono što ona pozitivno kazuje i imenuje te $\mathrm{s}$ druge neiskazivo i neizrecivo Božje »ti«, Bog koji u toj riječi treba biti zazvan. ${ }^{610}$ Kada se nadalje radi o vezi simboličnog govora i molitve, treba istaknuti to da je Bog uvijek veći, potpuniji, savršeniji (Deus semper maior) od svega što se može izreći odnosno predočiti simbolom. Welte se upravo zbog toga ovdje poziva na Karla Jaspersa i njegov govor o simbolu kao šifri. Jaspersova šifra je kodirano pismo, koja kazuje šifru transcendencije, to jest Boga, i ona nikada ne može biti razriješena. Jaspers će, naime, reći, kako je ta šifra čitljiva za moguću egzistenciju, što znači da egzistirajući čovjek, onaj koji je postao svjestan toga da stoji pred Bogom i kojeg ta svijest preobražava te on u tom smislu postaje egzistencijom, iščitava, odnosno dekodira do izvjesne granice šifru čime u prolaznim riječima, iako djelomično, ali ipak prodire u neprolazni smisao, tajnu Boga. ${ }^{611}$

U svojoj znamenitoj studiji Die Würde des Menschen und die Religion ${ }^{612}$ Welte ukazuje i na to da u današnjem svijetu govor molitve teško dolazi do izražaja, upravo jer je potisnut, no ipak čeka na dnu ljudskog srca. Jezik molitve i simbola je, dakle, postao težak, ali ne sasvim nemoguć. Kada se pitamo o tome kako onda treba osloviti Boga, Welte kaže kako lijep sažetak mogućeg odgovora na to pitanje daje Grgur Nazijanski u dva retka: »Sveimeni, kako da te zovem. Ti, jedini Bezimeni! « ${ }^{613}$

Nadalje, kada se radi o antropološkom polu molitve, treba reći kako onaj koji moli oslovljava u molitvi najprije Boga, ali to čini tako da svojim oslovljavanjem ujedno izriče i

\footnotetext{
${ }^{609}$ WELTE B., Filozofija religije, str. 181.

${ }^{610}$ Isto, str. 181.

${ }^{611}$ JASPERS K., Philosophie (zweite, unveränderte Auflage), Springer Verlag, Berlin - Göttingen - Heidelberg, 1948., str. 705-774.

${ }^{612}$ WELTE B., Die Würde des Menschen und die Religion, ur. Zaborowski H., Butzon und Bercker Verlag, Regensburg, 2017., str. 85-93.

${ }^{613}$ NAZIJANSKI G., Carmina (dogmatica) 1,1,29.: PG 37, 508. U istoj pjesmi upućenoj Bogu Grgur mu se obraća sljedećim riječima: Budi dobrostiv, Ti koji si Onostranost svega. Ovdje (ponovno) ukazujemo na Eckhartovski utjecaj na Weltea, gdje njemački mistik kao i kasnije B. Welte, Boga ne podvrgavaju kategorijalnosti.
} 
sama sebe te se tako dovodi u igru kao čovjek. ${ }^{614}$ Tamo gdje se čovjek kao on sam te ogoljen u svojoj bîti otvara Bogu, morat će sa sobom uz riječi dovesti i svoj sadržaj, svoj svijet ili sebstvo. Takva molitva se treba odlikovati iskrenošću i cjelovitošću. Iskrenošću nedostatnosti jer nije sama po sebi razumljiva i cjelovitošću, jer ju je potrebno prihvatiti kroz vjeru i ufanje. ${ }^{615} \mathrm{U}$ rečenicama Psalama se posebice da iščitati izlijevanje srca gdje se ništa u ne zadržava u sebi, već, pokrenuti riječima Psalama naša je „obveza“ prianjati uz Boga, i u trenutcima Njegove posvemašnje odsutnosti. ${ }^{616}$

Potpunost je još jedna karakteristika koja uz iskrenost biva zajednička molitvi i vjeri. Ono potpuno, cijelo, sve što jesam i što je u meni, treba se u govoru molitve otvoriti Bogu. ${ }^{617}$ To potpuno obuhvaća sve ono što ja jesam, moje brige, strahove i nadanja, u konačnici cjelovitost mojega sebstva, u kojem se moleći izlijevam pred Bogom.

Iz predočenog je razvidno kako upravo molitva otkriva relacijski značaj jezika. Naime, relacijski značaj jezika, očituje kako onaj koji moli, Boga uvijek oslovljava u njegovim simboličnim imenima te izričući time sebe i cijeli svoj svijet s Njim ulazi u izniman odnos. ${ }^{618}$ Konačno, odnošajnost govorne molitve razvija se, kako nas Welte poučava u mnoštvu konkretnih modaliteta: na način klanjanja i hvale, ili na način zahvale i molbe, ili konačno na način tužaljke i naricanja. ${ }^{619}$ Pri tome, zanimljivo, filozof religije u okviru molitve kao pobožnosti, posebno ističe zahvalu. Naime, onomu tko moli, Bog prvotno daruje molitvu s jezikom molitve, pa samo zato taj tko moli može sa svoje strane darovati Bogu svoju pobožnost s riječima svoje pobožnosti. Upravo iz toga razloga bîti molitve pripada da je ona uvijek (i) zahvala. ${ }^{620}$

\subsection{Molitva kao kult}

Molitva šutnje se ukida ${ }^{621}$ to jest dovršuje u molitvi kao govoru, a molitva govora $u$ molitvu kao kultu. Welte je bio mišljenja kako tek u kultu prepoznajemo onu visoku i

\footnotetext{
${ }^{614}$ WELTE B., Filozofija religije, str. 186.

${ }^{615}$ Posebice Ps 62,9 gdje stoji ukaz: „Izlijte svoje srce pred Bogom!ee

${ }^{616}$ Ovdje Welte posebice ističe Ps 22 gdje molitelj moli sljedeće: „Bože moj, vičem danju, al’ ne odvraćaš, vapim noću i nema mi počinkaee.

${ }^{617}$ WELTE B., Filozofija religije, 187.

${ }^{618}$ Usp. Isto, str. 188.

${ }^{619}$ Usp. Isto, str. 190.

${ }^{620}$ Usp. Isto, str. 191.

${ }^{621}$ Kod Weltea njem. izričaj aufheben i imenica Aufhebung znači isto kao kod Hegela ukinuti u kvalitativno potpunijem smislu negoli je to (tek) negacija. Ukinuti, shodno rečenom, znači uzdići, sačuvati, dovršiti; nešto se na jednoj razini ukida, da bi se uzdiglo na drugu, višu i ondje u preobraženom obliku sačuvalo kao cjelovito.
} 
posebnu mogućnost koja se nalazi u molitvi kao govoru. Kult se događa kao izvršenje zajednice; on je izvršenje i prikaz zajednice u kojoj se odvija. ${ }^{622}$ Zajednica je pri tom zbor ljudi koji su zajedno pogođeni Bogom te radi te pogođenosti zajedno i slave Boga. Bitak zajednice predstavlja biti jedan s drugim, biti u zajedništvu. Ovdje je prisutan dvostruki odnos posredovanja: s jedne strane Bog je taj oko kojeg se zajednica okuplja i koga slavi, a s druge strane svaki pojedinac, ako Bog ,živi“ u njemu, može živjeti tu cjelinu u zajedništvu s Bogom. Unutar zajednice uvijek je vidljivo jedinstvo unutarnjosti i javnosti. Svatko će moliti i vjerovati kao on sam, i to je unutarnjost jer sebstvo se ne može u vjeri okolo rasplinjavati. ${ }^{623}$ No svatko će isto tako zauzeto vjerovati i moliti u okviru zajednice kojoj pripada, a taj otvoreni prostor, koji sve obuhvaća i koji svakoga otvara prema svakome, nazivamo javnošću zajednice. ${ }^{624}$ Javnost zajednice se uvijek iskazuje i zbiva kroz riječ. Welte će reći kako molitva utemeljuje tu javnost kao bitak-za (za sve i svakoga) i kao bitak-sa (sa svima i svakim). ${ }^{625}$ Potrebno je reći i kako okupljanje zajednice na sabranost i molitvu ipak treba određenu podjelu uloga, pri čemu se posebno ističe pojedinac, predvodnik, svećenik, koji svojom riječju vodi zajednicu. To je riječ naviještanja. Odgovor zajednice kroz molitvu jest riječ molitve zajednice. Krug religije pritom jest upravo zbivanje molitve tako da prvo moli onaj koji je pozvan od Boga i njime pogođen, a onda on sa svoje strane nastoji u svojoj molitvi dodirnuti Boga. ${ }^{626}$ Kada se radi o naviještanju, treba također istaknuti kako postoji antropološki i teološki vid naviještanja. Antropološki pol se tiče govora jednog čovjeka drugima u zajednici, da bi ih svojim govorom dirnuo i pogodio. Teološki pol se odnosi na Boga koji je sadržaj toga govora. Za navjestitelja Welte kaže kako onaj tko navješćuje mora u svojem navješćujućem govoru najprije biti on sam, mora govoriti kao on sam, te mora govoriti $u$ ime i po nalogu Boga. ${ }^{627}$ Radi se o riječi koja je od Boga opunomoćena. Kao model za to Welte spominje Augustinove Ispovijesti koje predstavljaju ispovijesti osobnog, sudbinski bogatog poistovjećenja te govore polazeći od Boga koji je veći do osobne sudbine, a ipak je živ u osobnoj sudbini jednog pojedinca. ${ }^{628}$

Kult je primjerice molitva. Međutim, on se ne iscrpljuje sav u molitvi, već su tu u bitnome na djelu čini, ponašanje, koji samu molitvu preobražavaju (to jest u jednom dijelu ukidaju) u jednu višu dimenziju.

${ }^{622}$ Usp. WELTE B., Filozofija religije, str. 193.

${ }^{623}$ Isto, str. 193.

${ }^{624}$ Isto, str. 194.

${ }^{625}$ Isto, str. 194.

${ }^{626}$ Isto, str. 195.

${ }^{627}$ Isto, str. 196.

${ }^{628}$ WELTE B., isto, str. 197.; Usp. također: AUGUSTIN A., Ispovijesti, prev. Bajsić V., KS, Zagreb, 2012., str. 327. 
Sjedinjenje koje je u temelju govora naviještanja biva nošeno nalogom i hranjeno sjećanjem. Kada se radi o nalogu, treba reći kako nalog uzdiže onoga koji navješćuje nad kolebanja njegova osobnog poistovjećenja. Nalog čini postojanim poistovjećenje, a ta postojanost se iznutra hrani sjećanjem. ${ }^{629}$ Model za tu funkciju sjećanja koja čini postojanim Welte ponovno pronalazi kod Augustina (Ispovijesti VII, 17). On priznaje da nije mogao ostati stajati u svojem prosvjetljujućem iskustvu Boga - non stabam frui deo meo - ali da mu je sjećanje ostalo uz to iskustvo, te ga je ono, nepostojanog u toj stvari, učinilo postojanim: (M)ecum erat memoria tui. ${ }^{630}$

Još jedan bitan pojam kod Weltea kada se radi o naviještanju i molitvi kulta jest kolektivno sjećanje. Radi se o događajima koji su se zbili u prošlosti, ali oni, uvijek iznova obnavljajući se, trajno svijetle u sjećanju vjere svakog pojedinca unutar zajednice. Konačno, za naviještanje je nezaobilazno jezično jedinstvo sa zajednicom. Jezik zajednice jest jezik kojim ljudi međusobno komuniciraju. Na prvi pogled se čini površan, međutim, on sadrži zadivljujuću dubinu, a kako bi pokazao o kakvoj se dubini radi Welte upućuje na Sigmunda Freuda i njegovu metodu analiziranja jezika njegovih pacijenata s ciljem razotkrivanja podzemnih slojeva i pozadina tog jezika, dok je Paul Ricoeur odatle izvukao važne elemente za svoje „umijeće interpretiranja“. ${ }^{631}$ Riječ navještaja ima stoga zadaću dotaknuti i podići čovjeka, preobraziti ga i pokrenuti na konkretno djelovanje. ${ }^{632} \mathrm{Kroz}$ molitvu, zajednica dakle uvijek slavi Boga, to je jedno dijaloško zbivanje te svi sudjeluju u živoj komunikaciji sa svima. Boga treba shvatiti i prihvatiti kao Boga svih i svakog pojedinog. U konačnici treba reći kako je smisao kulta u zbivanju koje nazivamo communio, živa zajednica Boga s ljudima i ljudi s Bogom, ali ne manje važno i ljudi međusobno. ${ }^{633}$

\subsection{Prema zaključku: „Riječ“ i „kult“ kao moguće opasnosti izopačenja religije}

Iz predstavljenih je razmatranja o molitvi i više nego uočljivo da ih Welte ne drži nepovredivim, već je svjestan mogućnosti njihova izopačenja. Opasnost je to koja je pratila

\footnotetext{
${ }^{629}$ WELTE B., Filozofija religije, str. 198.

${ }^{630}$ AUGUSTIN A., Ispovijesti, str. 23.

${ }^{631}$ RICOER P., Interpretation. Der Versuch über Freud, Suhrkamp Verlag, Frankfurt a. M., 1969. i RÜTSCHE

J., Freud in der französischen Philosophie, u: Philosophische Jahrbuch, 78 (1971), 401-422.

${ }^{632}$ AUSTIN J.L., Zur Theorie der Sprechakte, Reclam Verlag, Stuttgart, 1972., 190-209.

${ }^{633}$ WELTE B., Filozofija religije, 205.
} 
čovječanstvo od njegovih početaka: ustrajavanje na formi te odmak od bîti religije. ${ }^{634} \mathrm{Ta}$ izopačenost krije se u razlici između njezine unutarnjosti i njezina vanjskog izražavanja, zbog čega se i u Bibliji javlja kritika religije: „Narod me ovaj usnama časti, a srce mu je daleko od mene“ (Mt 15,8; Mk 7,6). Za razliku od ateizma, koji otklanja i samu mogućnost kao i svaki oblik religije, ovaj je vid izopačenja religije mnogo suptilniji i teže uočljiv. Upravo zbog toga, prema Welteu, kult u sebi i krije najveću opasnost za religiju. Razlog tomu je punina vanjskog izražavanja koja vrlo lako može odmaknuti od izvršenja bîti te tako postati izvanjskom, međutim u konačnici ipak sačuvati oblik religije. ${ }^{635}$ Kult se, jasno, ne može poistovjetiti s ateizmom, međutim, zbog razloga koji je naveden, ateizmu dolazi vrlo blizu: štovanje koje to nije jer je na djelu izostanak vjere i pobožnosti u izvršavanju religije, što je pak u konačnici izostavljanje Boga samog iz kulta. Odatle dodirne točke s ateizmom.

Do ovakvih vidova izopačenja religije dolazi upravo zbog čovjekovih nagnuća spram znanja te poglavito moći za koje želi da postanu svemoćni odnosno da ih proširi preko svih ovozemaljskih granica i mogućnosti. Upravo se ovdje očituje izostavljanje Boga kao moći te se umjesto njega ističe vlastita moć i pokušaj njezina ostvarenja. Izopačenje kroz molitvu i kult, o kojem se ovdje govori, za posljedicu ima, prema Welteu, konkretne (vidljive) obrise, koji su, prema našem autoru, sadržani u sljedećem: umnažanje vanjskog bez bîti (supstancije), religija kao ideologija i religiozni fanatizam.

Prvi oblik izopačenja religije krije se u umnažanju vanjskog izražavanja religije. Ona nastaje tako da čovjek čvrsto drži ono dohvatljivo u govoru religije i osobito kulta, te zanemaruje ono bitno koje pri tomu treba doći do izražaja, prije svega, vjeru i pobožnost. ${ }^{636} \mathrm{~S}$ umnogostručavanjem oblika, bez istinske vjere i pobožnosti, dolazi se do toga da čovjek samoga sebe uzdiže i čini važnim u obliku religije. Religija kao ideologija je drugi oblik mogućeg izopačenja, gdje je religija svedena na instrument za postizanje estetskog užitka. Korijen takve ideologije može se pronaći u čovjekovoj vjeri u samoga sebe i vlastite ciljeve, gdje vjera ostaje tek nešto usputno, dok se s druge strane događa apsolutizacija sebstva u izvršenju religije. Čovjek je ovdje onaj koji želi biti svemoćan i jednak Bogu, no u konačnici doživljava razočaranje, jer postaje svjestan da su sredstva kojima raspolaže nedostižna. Welte ovdje posebno ističe mislioce poput Karla Marxa i Maxa Horkheimera, u čijim djelima se može naći dobar pregled povijesti pojma ideologije kroz prizmu religijsko-filozofijskog

\footnotetext{
${ }^{634}$ Isto, 220.

635 Isto, 221.

${ }^{636}$ Isto, str. 222.
} 
polazišta. ${ }^{637}$ Treći vid izopačenja prema Welteu jest religiozni fanatizam, koji predstavlja krajnje opasnu i još radikalniju apsolutizaciju čovjekova odnosa prema tajanstvenom bezdanu Boga koji je jedini apsolutan. ${ }^{638}$ Ovdje se radi o čovjekovoj nakani za apsolutiziranjem odnosa čovjek-Bog, pri čemu umišljaj vlastitog (jedincatog) izabranja između mnogih drugih mogućih, vodi ka samodopadnosti i isticanju. Krajnja posljedica, pak, ove vrste izopačenja jest radikalni preokret: od „tvrde“ uvjerenosti i sigurnosti, događa se potpuni pad u tjeskobu. Ovdje je Welte posebno ukazao na vrijedna razmatranja S. Kierkegaarda i njegov pojam tjeskobe $\mathrm{i}$ antipatije. Kierkegaard je tu vrst tjeskobe nazvao simpatetičnom antipatijom i antipatetičnom simpatijom. ${ }^{639}$ Ona je simpatija jer bi čovjek svom strastvenošću vlastita srca htio bezuvjetnost istine i sreće, htio bi zapravo Boga, međutim, Bogu mu, nakon (netom prikazana) razočaranja, postaje jedno strašno ništa. ${ }^{640}$ Stoga je tjeskoba ujedno i antipatija, jer se čovjek, da bi postigao tu bezuvjetnost istine i sreće, mora predati tajni koju nikada ne može pojmiti i koja mu zato ponekad izgleda kao ništa. Međutim, zbog navedenog izopačenja on uzmiče. ${ }^{641}$ Takvu napetost moguće je riješiti jedino skokom u vjeru kao što je to Kierkegaard u svojim djelima učinio. Čovjeka duboko pogađa to da on ne može sve znati i da je njegova volja konačna i uvjetovana te samome sebi pomaže tako da sve proziva prividom i da konačnost ne postoji, nema je.

Misli o izopačenosti religije uvijek ukazuju da religija ima ugroženi položaj između čovjekovih najviših i najmračnijih mogućnosti. No u konačnici ispravljanje svih izopačenosti vodi opet do tajne Boga, pri čemu valja biti svjestan da se ovo ,ponovno vraćanje na pravi put izvršenja odnosno ispravljanje religije, ne događa „od ljudi“ i njihove moći. Potonje upravo svjedoči, ponovimo, kako je Bog bio i ostao središte Welteove filozofije religije, koji je pak u konačnici jedini i istinski čuvar njene supstancije odnosno zaštitnik od svih izopačenja.

\section{Fenomen ateizma u Welteovoj fenomenologiji religije}

Vezano uz spomenutu problematiku izopačenosti koje su moguće unutar religije te problematike nepostojanja, Welte se osvrće i na ateizam kao pojavu suvremenoga doba te

\footnotetext{
${ }^{637}$ BIRNBAUM N., Die Religon in Geschichte und Gegenwart, sv. 3, Paul Siebeck Verlag, Tübingen, 1959., 567-572.; O Horkheimeru posebno u: SCHMIDT A., Kritische Theorie. Eine Dokumentation, sv. 2, S. Fischer Verlag, Frankfurt a. M., 1968., str. 375.

${ }^{638}$ WELTE B., Filozofija religije, str. 225.

${ }^{639}$ KIERKEGAARD S., Der Begriff Angst, ur. Richter L., Reclams Universal-Bibliothek, Hamburg-Berlin, 2002., str. 150-202.

${ }^{640}$ WELTE B., Filozofija religije, str. 226.

${ }^{641}$ Isto, str. 226-227.
} 
kaže sljedeće za ateizam: Ateizam je najprije trajna mogućnost ljudskoga života, za koju se čovjek slobodnom voljom, koja mu je darovana i koju posjeduje kao stvoreno biće, opredjeljuje. Naš autor kaže kako je moguće da čovjek donekle barem i izbjegne, suočavanje s tim zagonetnim ništavilom, koje se nalazi ispred i iza njega, može se zavaravati do jednog stupnja svoje spoznaje koja je uvijek nepotpuna i podliježe raznim komponentama koje utječu na istu. No najmoćniji izvor ateizma jest praiskonska čežnja čovjeka za vlastitim božanstvom, to jest za tim da poricanjem Boga stvori prostor za svoju svemogućnost, neograničenu slobodu i beskrajnu stvaralačku moć. ${ }^{642}$ Welte drži da se ovo suvremeno doba, i sve više prisutni ateizam, može prevladati samo jednom iskrenom i čvrstom vjerom, te na temelju iskustva koje imamo kroz povijest. U tom smislu naš će filozof religije, znakovito ustvrditi sljedeće: „Ako je vrijeme ateizma došlo, ono može opet otići, kao što su otišla tolika vremena“. ${ }^{643}$ Pitanja smisla - besmisla, postojanja nadalje nepostojanja, konačno bitka i ništavila, po definiciji dotiču univerzalno kozmička pitanja postojanja svega što jest. Welte se, nadalje, pita da li kozmički proces traje već oduvijek to jest da li mu možemo uopće odrediti početak ili je započeo s konačnim vremenom? To ćemo to pokušati u nastavku detaljnije razložiti. Ovdje ćemo se susresti s nekim poteškoćama, koje je Kant među prvima počeo propitivati, u smislu sukoba između određenih transcendentalnih ideja. ${ }^{644} \mathrm{U}$ nastavku ćemo pokušati objasniti što točno i na koji način je dovelo do sukoba u mišljenju i razumijevanju ideja koje uređuju čitav kozmos.

Kako je već naglašeno, božanskoga Boga u Welteovoj fenomenologiji religije shvaćamo kao beskonačnu „Tajnu“ koja nosi naš opstanak i daje mu smisao. S toga polazišta treba govoriti i o ateizmu kao sveprisutnom fenomenu koji se po cijelome svijetu proširio. Ljudski razum, naime, od kojeg ateizam polazi, ne prihvaća nikakav vid postojeće „Tajne“ koja ne bi bila razloživa i ljudskom kognitivnoj sposobnosti dostupna. U suprotnom zaslužuje jednostavno obilježje nepostojećeg. Za ateizam Welte kaže kako je postao moć ovog doba. „Ateizam je posve novi i zaprepašćujući fenomen, kojeg u toj dimenziji i širini nikada do sada nije bilo u povijesti čovječanstva“. ${ }^{645}$ Ateizam (grč. $\ddot{\alpha} \vartheta \varepsilon o \varsigma, ~ b e z ~ b o g a$, bezbožan) predstavlja skup različitih teoretskih načela ili praktičnih stavova što niječu ili ne poznaju Boga, kao biće koje je stvorilo svijet i njime upravlja, a istodobno u različitim oblicima prihvaćaju najviše

\footnotetext{
${ }^{642}$ VEREŠ T., Značajna »Filozofija religije«, u: CUS, 4 (1979) 8, str. 354.

${ }^{643}$ WELTE B., Filozofija religije, str. 165.

${ }^{644}$ Usp. Isto, str. 77.

${ }^{645}$ Usp. WELTE B., Die Würde des Menschen und die Religion. Anfrage an die Kirche in unserer Gesellschaft, Knecht, Frankfurt a. M., 1977., str. 96.
} 
načelo bezlične sile ili samoostvarajućega svjetskog poretka. ${ }^{646} \mathrm{U}$ tom smislu, pojam dalje upućuje na ono bezbožje to jest bezboštvo, koje teorijski i nadasve praktično poriče Boga. Jedan od autora kojeg svakako treba spomenuti kada se uopće i započinje govoriti o ateizmu jest Auguste Comte. Za njega povijest počinje religioznom fazom, da bi zatim prešla u metafizičku, te na koncu u našim danima u fazu pozitivne znanosti, koja se pak čini konačnim upotpunjenjem povijesti odnosno kao ona koja se potpuno oslobodila svih prethodno prevladanih faza. ${ }^{647}$ Kriza religije koja se događa uslijed ovih faza reći će Ž. Pavić jest „kriza otvorenosti i dijalogičnosti, kriza u odnosu na sebi intendirajuću individualnost, koja u svojoj biti nastoji sačuvati samoidentičnost u odnosu na identitet religijskog“، ${ }^{648}$

Isti autor po pitanju religije nadalje veli, kako ,čovjek uvijek ima potrebu za zajedništvom, on je intersubjektivno biće, a religija mu nudi jednu specijalnu vrst tog zajedništva - zajedništvo vjerujućih, odabranih i utoliko podvodi pod redukciju fenomen nevjere. Nevjera u ovom smislu predstavlja nepristajanje na granice zajedništva, težnju za beskonačnom otvorenošću i univerzalnošću komunikacije. Upravo o odnosu spram drugog ovisi trajnost religijskog zajedništva“ ${ }^{649}$ Pavić ovdje dobro ukazuje, da ateizmu u osnovi stoji „radikalni“ humanizam odnosno, zajedništvo s ljudima nadomješta (moguće) zajedništvo s Bogom. Svakako, ovime se navedeni citat ne iscrpljuje. Autoru je cilj, ukazati da autentičnost religijskog zajedništva ovisi isključivo i upravo o ljudskom zajedništvu, koje se, dakle u ateizmu, radikalizira. Što se tiče daljih izvoda o ateizmu kao takvom, vrijednim se nameće spomenuti znamenitog protestantskog teologa 20-st-.a Rudolfa Bultmanna koji donosi zanimljiv izričaj kada opisuje krizu koja zahvaća vjerovanje i religiju ,,svi slušaju svoje, nitko ne sluša drugoga“ ${ }^{650}$ Slično kao Pavić, i Bultmann ukazuje na čestu argumentaciju ateizma $\mathrm{i}$ ateista, a ta je da svojevrsna začahurenost u vlastitu religijsku zajednicu, koja zaboravlja „drugoga“" koji je i blizu i daleko, to jest na humani karakter uopće. I upravo zato treba težiti za većom otvorenošću te da komunikacija postigne jednu univerzalnost kako bi se sačuvao humani identitet religije i onog religijskog.

\footnotetext{
${ }^{646} \mathrm{U}$ tumačenju ateizma u njegovom pojmovnom (terminolškom) kao i sadržajnom smislu, oslanjali smo se na sljedeće autore: ULRICH F., Atheismus und Menschwerdung, Johannes Verlag, Freiburg-Basel-Wien, 1975., str. 75.; MURRAY J.C., Das Gottesproblem gestern und heute, Herder Verlag, Freiburg i.Br., 1965., str. 118.; WELTE B., Die philosophische Gotteserkenntnis und die Möglichkeit des Atheismus, u: Zeit und Geheimnis, Herder Verlag, 1989., str. 109-123.

${ }^{647}$ WELTE B., Filozofija religije, str. 145.

${ }^{648}$ PAVIĆ Ž., Egzistencijalne pretpostavke mogućnosti istraživanja religijskog načina bitka, u: FI, 9 (1989) 1, str. 64.

${ }^{649}$ Isto, str. 64.

${ }^{650}$ BULTMANN R., Die Krisis des Glaubens, u: Krisis des Glaubens - Krisis der Kirche - Krisis der Religion: drei Marburger Vorträge, Giessen, 1931., str. 14. i PAVIĆ Ž., isto, str. 64.
} 
Kada se radi o mogućim oblicima ateizma, treba spomenuti negativni ateizam, kritički ateizam i pozitivni ateizam. U tom smislu, prva vrsta ateizma koji Welte navodi jest upravo ovaj negativni kao onaj koji se tiče čovjeka i njegova postojanja u kojem se na očit način odriče Boga i priznavanja njegova postojanja.

\subsection{Negativni ateizam}

Što se tiče ovog prvog ateizma, on nastaje tako da se ljudsko biće toliko intenzivno orijentira na prisutnom bivstvujućem da sve drugo više nema nikakvu ulogu u njegovoj svjetskoj orijentaciji. ${ }^{651}$ Ovdje se radi o totalitarističkom načinu pogleda na svijet koji isključuje mogućnost postojanja ičega drugoga osim onoga što nam je moguće dokučiti i što je već negdje ustanovljeno. Pojedinac se ne opterećuje mišlju o Bogu, u njegovoj svijesti nema mjesta za to pitanje stoga to pitanje o Bogu mora izostati. Nastaje ateizam koji je ustvari negativan. ${ }^{652}$ Ovdje se ne kaže kako Bog ne postoji, već se o tome ne donosi baš nikakva tvrdnja. Možemo reći da ju se potpuno izbjegava. Problem Boga tu jednostavno ne dolazi ni u pitanje, jer već unaprijed otpada kao mogućnost i govora i promišljanja. U ovaj oblik ateizma možemo uvrstiti ateizam određenih oblika pozitivizma ${ }^{653}$ i neopozitivizma i također s njim $u$ ovom srodnog kritičkog realizma ${ }^{654}$. Treba spomenuti i marksistički ateizam koji totalizira ono što se može učiniti i to je, za njega, jedino bitno i važeće. Prema Welteovu mišljenju na

${ }^{651}$ WELTE B., Filozofija religije, str. 147-150.

652 Isto, str. 150.

${ }^{653}$ Pozitivizam (njem. Positivismus), smjer u filozofiji i teoriji znanosti. Razvio se u ranom XIX. st., a njegovi se začetci vezuju uz ime A. Comtea. Značaj pozitivizma vidljiv je u tome što velik dio znanstvenika koji eksplicitno odbacuje (neke) njegove postulate, u praksi ih prihvaća kao implicitne pretpostavke na kojima se njihova djelatnost zasniva. Jedan je od osnovnih postulata pozitivizma jedinstvo znanosti. Nema razlika između prirodne i društv. stvarnosti jer i jednom i drugom upravljaju zakonitosti, a svrha je znanosti njihovo otkrivanje. Ljudsko ponašanje i društv. akcija mogu se objasniti otkrivanjem njihovih uzroka na isti način na koji i svaki prirodni fenomen ima svoje uzroke. Pretpostavka o jedinstvu prirodnog i društvenog, a time i o principijelnom jedinstvu prirodnih i društv. znanosti jedna je od najžešće osporavanih pozitivističkih pretpostavki. Paradigmu pozitivističke analize u sociologiji predstavlja djelo É. Durkheima, koji je razvio tezu da je društvo kauzalna sila koja prethodi pojedinačnoj volji i koja ju objašnjava. Drugi je postulat pozitivizma jasno razlikovanje znanstvenih od neznanstvenih (metafizičkih, filozofskih, teoloških, vrijednosnih) tvrdnji. Načelo koje razdvaja ta dva područja, znanstveno i neznanstveno, proizlazi iz definicije znanstv. tvrdnji kao onih koje mogu biti iskustveno potvrđene ili opovrgnute. To se načelo u filozofiji logičkoga pozitivizma naziva načelom verifikacije. Tvrdnje kao što su: tiskanje novca od strane države obezvrjeđuje novac (to jest proizvodi inflaciju), ili vanjska prijetnja nekoj skupini povećava njezinu unutarnju koheziju, empirijske su tvrdnje koje se mogu verificirati kao istinite ili lažne. S druge strane, etičke tvrdnje o tome što je dobro ili loše ne mogu biti provjerene kao istinite ili lažne, jer se koncepti dobrog i lošega ne mogu podvrgnuti empirijskomu testu, u: BROZOVIĆ D., KOVAČEC A., RAVLIĆ S., Hrvatska enciklopedija, mrežno izdanje. Pristupljeno 30. 10. 2020. Dostupno na: https://www.enciklopedija.hr/natuknica.aspx?ID=49882

${ }^{654}$ Kritički realizam smatra da se, na osnovi kritički obrađenog iskustva i mišljenja, može postupno doći do dublje, potpunije i točnije spoznaje toga objektivno postojećega bitka, u: BROZOVIĆ D., KOVAČEC A., RAVLIĆ S., Hrvatska enciklopedija, mrežno izdanje. Pristupljeno 30. 10. 2020. Dostupno na: https://www.enciklopedija.hr/natuknica.aspx?id=52108 
ovaj način funkcioniraju i znanosti i tehnologija, koje u okviru pretpostavljenog sistema te unaprijed zadane metode omogućuju utvrđivanje i prosuđivanje svega već postojećeg, i u tom smislu ovaj negativni ateizam postaje instrument kako znanstvenog tako i primjerice marksističkog načina mišljenja, jer se marksizam (neopravdano) redovito pozivao na znanost, kako prirodno-tehničku tako i društvenu. Iz tog razloga marksistički ateizam možemo nazivati i negativnim ateizmom. ${ }^{655}$

U strukturi negativnog ateizma ovog tipa nalaze se dva momenta, na koje valja obratiti pozornost. Prvo je orijentacija na postojeće u njegovoj sposobnosti da ga se utvrdi i da se njime raspolaže. Iz toga proizlazi veliki svijet znanosti i tehnike. U znanosti i tehnici se postupa po već spomenutom načelu Huga Grotiusa: „etiam si deus non daretur“.656 Pretpostavlja se dakle potpuni i radikalni izostanak bilo kakvog oblika transcendencije. No, treba reći i kako se u ovom vidu ateizma ne isključuje Boga potpuno iz svijesti pojedinca, odnosno ovaj ateizam nije takoreći militantan to jest onaj koji mu je prvotni cilj „osloboditi“ ljude Boga, već se radi o totaliziranju u vidu klasičnog apsolutiziranja principa znanosti i tehnike koje bivaju postavljene kao ono od čega nema većega, dopuštajući kao posljedicu tog apsolutiziranja upravo i sam izostanak Boga. Pouzdanje koje su ljudi prije imali u Boga, sada bi trebali imati u znanost i tehniku. U totalizaciji se, s obzirom na ovu vrstu ateizma, smatra kako se sve može ,dohvatiti“ to jest spoznati na način empirijske znanosti, ili riječima B. Weltea, ono što se u znanosti može znati jest u biti cjeline svega postojećega ${ }^{657} \mathrm{Iz}$ predočenog je vidljivo, zašto Welte radije koristi riječ totalizacija: radi se o onomu što se znanstveno principijelno može znati i to je ujedno sve ono što jest, dok izvan toga - logički nužnog i spoznatljivog koje vrijedi kao apsolut, nema ničega. ${ }^{658}$

Prema Welteu, ovo totaliziranje znanosti i tehnike nosi sa sobom jedan novi svjetonazor koji biva prihvaćen na više strana u ateističkim krugovima, pri čemu jednostavno izostaje svaki razlog odnosno postaje suvišno postavljanje ikojeg smislenog pitanja o Bogu. Treba reći kako i ovaj negativni vid ateizma predstavlja jedan oblik vjerovanja, za one koji na njemu inzistiraju. Težnja za postizanjem totaliteta, volja za cjelinom, želja za empirijskom verifikacijom apsolutno svih postojećih teza jesu stvarni temelj ove vrste ateizma. S Welteom treba istaknuti kako ova vrsta ateizma u sebi sadrži pozitivni element: $\mathrm{Na}$ tragu prosvjetiteljske ideje o čovjekovu nužnom napretku kroz znanost te povrh svega njegovoj

\footnotetext{
${ }^{655}$ Usp. WELTE B., Filozofija religije, str. 147.

${ }^{656}$ Usp. Isto, str. 148.

${ }^{657}$ Isto, str., 147.

${ }^{658}$ Isto, str. 149.
} 
naravnoj potrebi za spoznavanjem odnosno znanjem, možemo, kod B. Weltea, iščitati (i) pozitivni aspekt ove vrste ateizma koji je, dakle, sadržan u čovjekovoj želji štoviše nagonom za znanjem, ali i to je ključni moment unutar kojeg on sebi sam zadaje cilj. U tom smislu, ovaj se ateizam, unatoč istaknutoj (djelomičnoj) pozitivnosti, ne može oduprijeti prigovoru isključivosti i parcijalnosti - istinito je samo ono što se dade spoznati na način pozitivističkoeksperimentalne metode, dok sve drugo koje izlazi iz tog okvira (Transcendentno to jest Bog), razložnog objašnjenja i time objektivnosti to jest realnosti.

\subsection{Kritički ateizam}

Uz negativni ateizam pojavljuje se i druga vrsta koja se naziva kritički ateizam. Ovdje se radi o tome da se ne niječe misao o Bogu. Bog biva u kritičkom ateizmu prihvaćen tek kao postojeća činjenica. Opasnost koju ova vrsta ateizma ističe krije se u tome što nastaje privid Boga koji bi se mogao odrediti nekom definicijom i biti poznat unutar okvira te iste. $\mathrm{U}$ tom slučaju često se događa to da se umanji Božja transcendencija, Welte rabi izraz izopači, jer Bog više ne predstavlja tajnu koja nadilazi svaki postojeći pojam i on postaje samo ono što taj pojam ili definicija o njemu kaže. ${ }^{659}$ Tako spoznati Bog često biva shvaćen kao konkurencija ostalim unutarsvjetskim iskustvima koja su već znana. Pretpostavlja se znanje o tome što je to Božja pravda i često se dolazi u nesuglasicu s iskustvima stvarnih nepravdi koja se događaju u svijetu. Mišljenje sámo postaje vrjednije od mišljenog Boga te Bog koji biva mišljen može također biti mišljenjem podvrgnut sumnji, a na koncu svrgnut i ubijen. ${ }^{660}$ Sljedbenici ovog ateizma smatraju sljedeće: tko Boga smatra postojećim i da ga može dohvatiti svojim znanjem i pojmovima, tada svojom vlastitom definicijom i raspolaže Bogom. To za posljedicu ima to da čovjekova misao postaje moćnija od Boga. ${ }^{661}$ I više je nego očito kako ova vrsta ateizma sadrži kritički moment koji nije za zanemariti. Mišljenjem ovladati Bogom, nagnuće koje je pratilo teologe svih vremena. Upravo da bi to izbjeglo te u prilog ovoj vrsti ateizma, ide i poznato načelo protestantske teologije „totaliter aliter“, kojeg u svojoj teološkoj misli najjasnije iznosi Karl Barth: Bog je u potpunosti drugačiji da bi ga se ikakvom misaonopojmovnom strukturom dalo predočiti. Osim Bogom „ovladavanju“ Bogom u ovoj vrsti ateizma na vidjelo izlazi skrivena težnja ovladati svime, uzdići se ponad Boga i njegove

\footnotetext{
${ }^{659}$ Isto, str. 150.

${ }^{660}$ Welte preporuča Heideggerov spis koji posebice govori o ovoj vrsti ateizma; Nietzsches Wort, Gott ist tot, u: Holzwege, Frankfurt a.M., 1950., str. 193-247.

${ }^{661}$ WELTE B., Filozofija religije, str. 151.
} 
transcendencije te vlastito mišljenje postaviti kao jedino ispravno prema kojem se temelji svako daljnje umovanje. Postojanje kritičkog ateizma Welte dovodi u svezu s teodicejskim pitanjem i problemom koji se na tom putu nameće, a to je pitanje zla i patnje u svijetu i mogućnosti Božje opstojnosti s obzirom na tu činjenicu.

U razmatranjima pitanja zla na svijetu, temeljno je pitanje uobličeno u izričaj, ako postoji Bog, odakle odnosno zašto onda zlo? Ako postoji tako savršeno, te povrh svega svemoguće biće kako je onda moguće da postoji zlo. Jedno od rješenja, svakako nedostatno jest ono u tumačenju moralnog zla kojem je izvor u čovjeku to jest njegovu nagnuću postati corruptio, izvitoperiti svoju narav kroz zlo odnosno, laž, prijevaru, nasilje itd. Josip Kribl u tom pogledu kaže sljedeće: „razlikovanje između dobra i zla usko je povezano s odnosom Boga i čovjeka. Povezano je s pitanjem Božje i čovjekove slobode, slobode i milosti. Nesuglasice koje proizlaze između stvoritelja i stvorenja - čovjeka, stoje pod znakom grijeha i Boga koji ne voli grijeh. Grijeh prožima sve ono što nazivamo ljudskim“. ${ }^{662}$ Osim u specifično teološkom pojmu grijeha, za ovu vrstu zla se većinom rabi pojam ljuske slobode. „Podrijetlo zla (osim prirodnog op. a.) tumači se redovito slobodom, koju je Bog darovao čovjeku i koju je čovjek zlorabio“. ${ }^{663}$ Svemogući Bog računa na čovjekovu (parcijalnu) slobodu da s njom raspolaže u okviru vlastitih mogućnosti i kontekstualnosti u kojoj se zadesio, uvažavajući razlikovanje između dobra i zla, no čovjek često u želji za osobnim probitkom i ostvarenjem svoje vlastite moći zaboravlja da je konačno biće koje ovisi o svome Stvoritelju.

Pitanje opravdanja postojanja Boga u odnosu na zlo u svijetu, kroz čitavu je povijest bilo predmet razmatranja kako filozofa tako i teologa. Kao svojevrsna referentna točka, posebno s obzirom na izričaj, ovdje isplivava Leibniz uz kojeg se na prvi izričiti način veže izričaj teodiceja. On je pod tim izrazom označavao onaj dio filozofijske i teologijske refleksije u kojem se upravo postavlja problem kako postojanje dobrog i svemogućeg Boga učiniti spojivim s prisutnošću zla u svijetu? Kako dvjema međusobno isključujućim stvarnostima „dopustiti“ da postoje istovremeno? ${ }^{664}$

U skladu s etimologijom pojma (theos: Bog i dike: pravda), teodiceja predstavlja pokušaj opravdavanja Boga time što ga se zapravo brani i oslobađa tužbe da je odgovoran za zlo u svijetu. Leibniz promatra problematiku Boga i zla u kontekstu supostojanja razuma i

\footnotetext{
${ }^{662}$ KRIBL J., Problemi dobra i zla u etici N. Berdjajeva, u: BS, 47 (1977) 1, str. 87.

${ }^{663}$ Isto, str. 88.

${ }^{664}$ LEIBNIZ G.W.F., Teodiceja - ogledi o dobroti Božjoj, slobodi čovjekovoj i podrijetlu zla, Demetra, Zagreb, 2012., str. 41.
} 
vjere te očituje uvjerenje kako niti vjera i razum ne mogu proturječiti jedna drugoj te u svojoj Teodiceji iznosi: ,pretpostavljam da dvije istine ne mogu proturječiti jedna drugoj; da je predmet vjere istina koju je Bog neobično otkrio; također da je razum poveznica istina, ali posebice (kada se usporedi s vjerom) onih koje ljudski duh može, bez pomoći svjetla vjere, prirodno dosegnuti“ ${ }^{665}$ Leibnizova je teza je da ako se prizna postojanje vrhunski dobrog i mudrog Boga, iz toga slijedi da On za svoje stvorenje može dati i izabrati samo ono najbolje. Istina, kao što je manje zlo isto jedna vrsta dobra, tako i manje dobro može izgledati kao neka vrsta zla koja sprečava veće dobro. Međutim sve je u svijetu, počevši od njega samog do čovjeka ispunjeno „manje“ dobrim pri čemu je vidljivo da je upravo to povod Božjeg poziva čovjeku na veće dobro, i samim time na njegovu izgradnju. Teologija će u tom smislu govoriti o ,čovjekovom sudjelovanju na Božjem činu stvaranja“. Tako je čovjek ne samo pozvan nego i dužan usavršavati nepotpuni svijet i sebe u njemu. ${ }^{666}$ Stoga, prema Leibnizu svijet koji je stvorio Bog je jednostavno najbolji mogući svijet pa i s očitim nesavršenostima u njemu kao što je zlo.

Kada se pak radi o kršćanskoj teodiceji, tada se nužnim nameće spomenuti dva kršćanska velikana, Tominu Akvinskog i Aurelija Augustina. Obojica su se uhvatila u koštac s ovom teškom temom. Teodicejska pitanja koji svaki od njih na osobit način obrađuju u bitnome nose, jasno, kršćansko-biblijsko obilježje te su samim time i slična: suprotstavljanje ontologiziranje zla, te opravdanje postojanja dobrog Boga unatoč zlu koje je na djelu u svijetu. Promišljajući, tako o Teodiceji, oba autora vele, da oba zla, i prirodno i moralno - ako ih Bog predviđa kao slučajnu posljedicu ili ih dopušta s gledišta većega dobra -, ipak imaju pozitivnu funkciju. Ovdje se na poseban način i kao dimenzija ustrajnosti donosi biblijski lik Joba. Podnošenje zla kod Joba je utoliko specifično, što on za zlo ne optužuje Boga, štoviše, on ga brani. On zlo podnosi u zauzetoj nadi i jasno vjeri, koje osim unutarnjeg stava imaju i svoju praktičnu dimenziju. U tom smislu samo „Jobovsko“ podnošenje zla ovdje nije nikakvo prepuštanje očaju (već spomenuta obrana Boga to dovoljno govori), već odgovor biblijskog, a time i čovjeka kršćanina uopće, da je zlo u konačnici tajna, kojom jedino Bog može ovladati. I premda zlo po sebi djeluje apsurdno, nemoguće je govoriti o totalnoj apsurdnosti zla u svijetu, jer bilo koje zlo, pa i ono koje je prividno lišeno svrhe, ne izmiče Božjem

\footnotetext{
${ }^{665}$ Isto, str. 43.

${ }^{666}$ Isto, str. 69.
} 
providonosnom planu, dade se iščitati kako iz filozofije o zlu ova dva velikana, tako kršćanskog pristupa zlu uopće. ${ }^{667}$

\subsection{Pozitivni oblik ateizma}

Pozitivni oblik ateizma se pojavljuje nakon negativnog i onog kritičkog i predstavlja ateizam koji ukazuje na čovjekovu uvijek nepresušnu potrebu za ostvarenjem cjeline. Welte smatra kako se pozitivni ateizam može pojaviti kao „volja koja hoće sve znati i svime vladati“. ${ }^{668} \mathrm{U}$ tom slučaju ova vrsta pozitivnog ateizma može postati nezasitna želja prekoračiti sve granice ljudske moći i znanja. No, u tom svom stremljenju pozitivni ateizam se, Welteovim riječima, ,sudara s Bogom za kojega se kaže da postoji“. 669

Ova ideja volje za cjelinom koja se pojavljuje u konačnom čovjeku često ga navodi na, za Weltea pogrešan put, u zaboravljanju konačnost svoje moći i mogućnosti vlastitog svijeta koje se (mogućnosti) također konačne. U toj konačnosti se rađa želja pojedinca da bude svemoguć i sveznajući, pa i božanski. Kako je želja nezasitna to jest nikada ne može biti u potpunosti zadovoljena, upravo se, prema Welteu, iz tog stanja željā za ovladavanjem rađa borbeni ateizam. Welte smatra kako ovaj ateizam ,pozitivno, aktivno i polemički postavlja negaciju Boga“6 670

U kontekstu govora o pozitivnom ateizmu Welte spominje Friedricha Nietzschea i njegov koncept volje za moć i smrti Boga unutar povijesti. Prema Nietzscheovu mišljenju, povijest nikada nije nešto dovršeno. Povijest govori uvijek nešto novo. Prema nekim autorima u Nietzschea „historijsko obrazovanje te povrh svega znanost treba biti u službi budućnosti i vođeno nekom budućom kulturom“. ${ }^{671} \mathrm{~S}$ obzirom na ateizam, Welte ovdje ne ističe toliko Nietzscheovo prevrednovanje vrijednosti i u tom kontekstu „smrt Boga“, već znanost (Nietzsche je osobito protežirao psihologiju) kao onu koja će voditi ka svijetloj budućnosti „rušenja svih idola odnosno bogova“. Nailazeći na svojevrsni paradoks upravo se ovdje očituje Nietzscheov stav prema znanju i znanosti te njihovoj ulozi u svijetu - sadašnjosti te budućnosti. Nietzsche se stavlja, nasuprot prosvjetiteljske ideje protežiranja razuma kao takvog iznad svega, međutim i upravo radi toga ističe pojam sveobuhvatnog čovjekova znanja

\footnotetext{
${ }^{667}$ AGUTI A., Filozofija religije. Povijest, teme, problemi, str. 276.

${ }^{668}$ WELTE B., Filozofija religije, str. 150.

${ }^{669}$ Isto, str. 150.

${ }^{670}$ Isto, str. 151.

${ }^{671}$ JELKIĆ V., Kraj povijesti ili nova epoha?, u: Metodički Ogledi, 15 (2008) 2, str. 81.
} 
i čovjeka samog. Ne spoznaje i ne napreduje razum, već čovjek za Nietzachea. Upravo je to izvrsno uvidio B. Welte u detektiraju Nietzscheova pozitivnog ateizma jer se ovdje čovjeka stavlja nasuprot i iznad svega, pa jasno i samog Boga. Upravo je ovo Nietzscheovo radikalno ostavljanje čovjeka u središe, vodilo našeg filozofa prema daljnjim izvodima odnosno sličnostima drugih filozofsko-društvenih pravaca. Welte smatra, naime, kako se ovdje može vidjeti i korijen marksističkih ateizama. „On (marksistički ateizam op. a.) se sastoji u tome da marksizam tvrdi da se povijesni hod čovjeka prema idealnom konačnom stanju može postići isključivo ljudskom snagom i inteligencijom“. ${ }^{672}$

Kako s obzirom na Nietzschea tako i marksizam na koji se naš filozof religije ovdje nadovezuje, isplivava prema njemu ovdje pitanje moći svom silinom na površinu. Radi se o štoviše o nadmoći kao takvoj. U tom smislu Welte zaključuje da je „taj fenomen bez sumnje blisko srodan sa voljom za moći kod Nietzschea, iako to na prvi pogled ne izgleda tako. Pred tom voljom i pred tim postulatom Bog nema mjesta“. ${ }^{673}$ To je postulat kojim ateizam samoga sebe želi vidjeti nadmoćnim, ponajprije znanjem, a zatim, dakako i drugim načinima. U marksističkim sustavima je itekako uočljiva težnja za moći ovladavanja svim procesima života i stvarnosti pri čemu izričaj „totalitarni“, koji se marksističkom sustavu s pravom pripisivao, ovdje najbolje odražava navedene težnje. Štoviše ova vrsta ateizma uopće ne skriva svoju želju za postizanjem apsolutne moći pogotovo nadmoći ponad svim postojećim.

Zanimljivost u Welteovu pristupu pozitivnom ateizmu jest ta da mu on pridaje kategoriju iskrenosti, štoviše kategoriju ,istinitosti“, u jasno krajnje ograničenom i doziranom smislu. U tom će smislu on istaknuti kako je ovaj ateizam ,najčišći i tako najistinitiji jer je najmanje skrivajući oblik ateizma“ ${ }^{674}$ Za zaključiti je da Welte ovaj pozitivni ateizam naziva pozitivnim i pozitivno ga vrednuje zato što ovaj ateizam ne skriva svoju želju za moći.

\subsection{Iskustvo patnje i Boga koji ,kažnjava“}

Vezano uz teodicejsko pitanje o zlu pojavljuje se i pitanje iskustva patnje i Boga koji „kažnjava“ ili u najmanju ruku dopušta da čovjek (bezrazložno) bude podvrgnut patnjama. Konkretnom, postojećem čovjeku koji pati i koji je u stanju nekog trpljenja, teško je izbjeći misao i poimanje Boga koji ga kažnjava. Čovjek ovaj vid iskustva proživljava kroz borbu i

\footnotetext{
672 WELTE B., Filozofija religije, str. 151.

${ }^{673}$ Isto, str. 151.

${ }^{674}$ WELTE B., isto, str. 151.
} 
patnju no ipak treba imati na umu kako je to poimanje Boga koji bi kažnjavao čovjeka tek tipično i samo ljudsko poimanje. Radi se o poimanju kakvo je svojstveno ljudskoj pravi jer trpeći čovjek, što je po sebi i naravno, redovito traži razlog svojeg trpljenja, odnosno odgovor na pitanje zašto? Idući dalje, i na čisto fenomenologijskoj razini, redovito iznalaženje odgovora na ovo pitanje ne ide u jednolično racionalnom smislu traženja tek uzroka, već u smjeru traženja „odgovornih“, nekoga, dakle, tko je odgovoran za stanje „koje mi se događa“. U tom smislu, razlog vlastite patnje ljudi pronalaze redovito u drugim osobama odnosno i na kraju samom Bogu. Čini se da je to svojevrsna čovjekova prirodna potreba. Zanimljivost je tim veća, što se i u ateističkom konceptu koji Boga ne priznaje postojećim, upravo, poput crvene linije provlači ova nakana, naime, postavljanja „pitanja“ direktno i samom Bogu. Međutim, vrijedi i drugo, čemu nas poučava upravo Welte: olako i brzopleto iznalaženje odgovorā na patnju problem i samu nerješivost patnje i trpljenja samo produbljuje, a nikako ih ne rješava. U tom smislu ovaj teolog i ne pokušava nuditi konačne i dovršene odgovore na zlo i patnju u odnosu prema Bogu. Štoviše, na temelju Evanđelja potpuno se protivi slici „Boga koji kažnjava““. On je uvjerenja kako je Bog, i to onaj božanski Bog, veći i tajanstveniji od te ljudske slike, a kroz patnju to izlazi na vidjelo. ${ }^{675} \mathrm{O}$ čemu se radi kada s Welteom pojam patnje (jednostavno) vežemo uz pojma tajne ili, još jasnije, otajstva? Smjer odnosno put koji naš autor ovdje pokušava doznačiti, jest pojam poniznosti nasuprot moći. U tom smislu svijest o nedokučivosti tajne patnje nije odgovor još manje rješenje koje bi Welte ponudio s obzirom na patnju. On više ukazuje na činjenicu ne-do-kraja-spoznatljivosti same patnje, pri čemu svakim novim iskustvom o njoj, sve dublje poniremo u tu tajnu i tajnu Onoga koji svime ravna.

Svakako, treba reći kako se nedokučiva tajna Boga ne umanjuje činjenicom patnje, naprotiv, ona dobiva tada još veću smislenost i utemeljenje. Ako ikoje drugo ljudsko iskustvo, onda se patnja veže uz pitanje o smislu te je ovdje zanimljivo kako Welte predlaže da jednostavno treba izdržati Božju šutnju. Slično kao i u primjeru biblijskog lika Joba, vrlina poniznosti nasuprot moći predstavlja aktivni princip suočavanja s patnjom, kako u teorijskom smislu propitivanja tako i u praktičnom, podnošenja iste. Tako vjera u Boga, koji sve nadilazi, biva itekako moguća i pred horizontom koji Welte naziva, „horizont patnje“. Istina, vjeru postaje teže ostvariti jer na čovjeka pada teški teret patnje. Čovjekovoj naravi pripada da

${ }^{675}$ Isto, str. $154-156$. 
vjeruje da je Bog neshvatljiv i neizreciv, veći od svih pretpostavki pravde koje ima u svojem umu. U tome se sastoji ono, što se može nazvati Božjim teretom. ${ }^{676}$

Welte ističe kako je borba protiv patnje prirodna. Ta borba može i mora granice patnje uvijek iznova pomjerati i tako joj oduzimati dio ljudskog terena. Ali to nije borba protiv Boga to je prije borba s Bogom za stjecanje ljudskoga u čovjeku. Borba, iako je nužna, svejedno nije nikada uspjela odstraniti patnju od rodova smrtnika. ${ }^{677}$ Ona ostaje te je čovjek pozvan boriti se protiv nje. Tu i tamo će se s tim pitanjem o smislu patnje moći doći do korisnog zaključka. Ali sve u svemu ovo pitanje nema obuhvatljiv i znan odgovor. Upravo to, što se na njemu (pitanju) očituje njegova besmislenost, čini oštrinu boli patnje. Ne idemo protiv razuma ako vjerujemo i nadamo se da je u patnji smisao sačuvan. To treba činiti predlaže Welte. Na kraju ostaj Bog, kao konačni princip. Nikako u vidu projiciranja, već katovski rečeno, garanta smisla ljudske patnje. Svakako, ljudski pred njome žalovati, kao što su to činili Job i Jeremija. Welte se ponovno vraća, na već spomenutog Joba te uz Jeremiju kojeg on također ističe, pokazuje velike i uvijek iznova vrijedeće oblike vjerovanja u biblijskog Boga, koji je, ne zaboravimo to, također patnik. U biblijskoj knjizi o Jobu govori se na izričit način o problemu zla, gdje glavni protagonist Job žaluje svoju muku koju doživljava te pita Boga o tome što ga je snašlo. Job svoje „slabosti“, ima kao konačno biće prikazuje Bogu i na kraju biva blagoslovljen mnogim dobrom. Knjiga o Jobu ima dvije poruke: kao prvo trpljenje je ispit, test koji treba proći da bi kasnije stigla nagrada; te druga poruka koja pokazuje kako Bog u svojoj moći ne objavljuje unaprijed razloge svojih djela. ${ }^{678}$

Važnim se nameće reći i sljedeće: Welte je svjestan da patnja može postati u jednom trenutku čovjekova života toliko velika i tajanstvena da izbriše Boga iz svijesti onih koji pate. Očaj može biti takav, da preraste u uvjerenje ne samo o nepostojanju Boga, već i besmislenosti zahtjeva za Njegovim postojanjem. Međutim, važno je uočiti da je ovakav (trenutni) stav upravo proizlazi iz snažnog doživljaja patnje, pri čemu je vidljivo da je uvjerenje odnosno zahtjev za „nepostojanjem“ Boga proizašao iz teškog trpljenja. S druge pak strane, mnogo su učestaliji primjeri, prema njemu, da Bog u patnji ojača čovjeka, pri čemu on (čovjek) postaje u egzistencijalnom smislu možemo reći napreduje. Pri tome mislimo na spoznavanje, doživljavanje, osjećanje svega oko sebe. Upravo pojam duhovnosti u njenoj sveukupnosti (netom nabrojanog) igra prema Welteu, u patnji iznimno važnu ulogu. Kada se stoga govori o patnji kao jednom od uzroka ateizma, tada je on prema Welteu moguć ali nije

\footnotetext{
${ }^{676}$ Usp. Isto, str. 154-156.

${ }^{677}$ Usp. Isto, str. 154-156.

${ }^{678}$ Usp. PLANINIĆ J., Problem zla u svijetu, u: Obnovljeni Život, 66 (2011) 3, str. 351.
} 
nužan. „Ateizam, čini se, ima svojevrsnu povijesnu sudbinu i potrebu za pojedince koji su mu se priklonili“ ${ }^{679}$ Gledajući na povijest i trenutnu situaciju u kojoj se nalazi suvremeni čovjek novog doba, Welte je mišljenja kako je zasigurno došlo vrijeme ateizma, ali i kao svako drugo vrijeme ono može i doći, ali i otići. Za one, za koje je Bog postao živo iskustvo, uvijek preostaje neki put vjerovanja. Vjernik uvijek treba na prikladan način živjeti sa svojim ateističkim suvremenicima, uz poštovanje i uvažavanje misli koje su na djelu, ali pri tom zadržavajući svoj put i misao. Upravo zbog toga u djelu Über das Böse. Eine tomistiche Untersuchung Welte opominjući ističe kako se zlo koje čini čovjek može prikazati kao odbacivanje vlastita temelja i želja za ostvarivanjem sebe samoga pouzdanjem jedino u svoje snage i to uz poricanje Boga i Božje milosti i ljubavi koje On gaji za čovjeka. ${ }^{680}$

Božje stvaranje razumskih bića moralo je uključivati i mogućnost zla, da čovjek tu mogućnost ostvari i da je to ostvarenje, koliko god Bogu nije milo, bilo dopušteno, jer bi se u suprotnom naime da se zlo nije dopustilo, na neki način išlo protiv čovjekove naravi, odnosno bitnog ustroja bića kojeg je Bog tako htio i kojeg je stvorio. ${ }^{681}$ Kada bi, stoga, isključio navedenu mogućnost kako zla po sebi tako i ljudske patnje, Bog bi bio u proturječju sa samim sobom, jer bi time isključio svaki vid gradacije, stupnjevitost bitka te mogućnosti rasta uopće. To što je Bog dopustio zlo moglo bi se tumačiti kao određena vrsta nemoći, ali nemoći u smislu očuvanja prostora čovjekove slobode, koja uključuje mogućnost patnje za samoga sebe i za svoje bližnje upravo kao osnova mogućnosti kvalitativnog napretka. ${ }^{682}$ Očuvanje ovakvog oblika slobode je zapravo izraz Božje ljubavi te je prema Sartreu kojeg Welte u ovom kontekstu dotiče, to isto tako izraz Božje ranjivosti koju On prihvaća pri stvaranju ljudi, ranjivosti koja je, ako se dobro sagleda, puno veća u odnosu na čovjeka. Ranjivost je ovdje druga riječ za ljubav, koje kod Boga ne može ponestati kao što se to događa u čovjeku. ${ }^{683}$

Stoga, ako bi Bog stvorio čovjeka čija bi djela nepromjenjivo i nužno morala biti dobra takav čovjek uopće ne bi bio čovjek u općeljudskom smislu - niti autonoman i samim time niti slobodan pojedinac koji ima pravo odlučivati upravo prema pripadnoj mu slobodnoj volji. Prema pojedinim autorima, ovdje je upravo u pitanju ,epistemička distanca između Boga i čovjeka, koja je posljedica božanske transcendencije te istodobno predstavlja jedan od nužnih uvjeta za izvršenje čovjekove slobodne volje.“6844 Kada se pak nadalje radi o poimanju

\footnotetext{
${ }^{679}$ Usp. WELTE B., Filozofija religije, str. 154-156.

${ }^{680}$ WELTE B., Über das Böse. Eine tomistiche Untersuchung, Herder, Freiburg i. Br., 1986., str. 43.

${ }^{681}$ AGUTI A., Filozofija religije. Povijest, teme, problemi, str. 318.

${ }^{682}$ Usp. Isto., str. 318.

${ }^{683}$ Isto, str. 318. i SARTRE J.P., L'essere e il nulla, Mondadori, Il Saggiatore, Milano, 1958., str. 450.

${ }^{684}$ AGUTI, Filozofija religije. Povijest, teme, problemi, str. 269. i 323.
} 
Božje kazne, koja je usko vezana uza pojam zla i nepravde u svijetu, tada to treba shvatiti na način prepuštanja čovjeka samome sebi, opet u kontekstu vlastite mu slobode jer čovjek je $u$ i kroz grijeh (grijeh uzet u strogo kršćansko-crkvenom smislu) odnosno negiranju vlastite osobnosti htio sebe upravo takvog i s takvim načinom ostvarenja. Božja se dobrota, svakako, može odijeliti od njegove pravednosti, a pravednost je, prema klasičnoj definiciji, u tome da se svakome dade što mu po naravi i zasluzi pripada. Međutim, i ovdje je odnos dobrote $\mathrm{i}$ pravednosti poglavito ako posegnemo za Evanđeljem protkan u najmanju ruku, za ljude, ne do kraja razložnim to jest shvatljivim odnosnom. U tom smislu ovdje vrijedi posegnuti za blagom evanđeosko-protestantske teologije Milosti, koja princip dobrote i pravednosti u Boga ne svodi na „logičnu“ i „razumljivu“ kategoriju zasluge i uskraćivanja dobara od strane Boga, već na otajstvenu Božju slobodu i promisao koji čovjeku nikada neće biti do kraja razrješivi i dokučeni. ${ }^{685}$ Svakako, kršćanska (posebice katolička) će teologija reći da je patnja i bolest posljedica (ne kazna) čovjekova odreknuća od Boga u samim počecima - radi se o Teologiji stvaranja i izgona iz raja, pri čemu posebno do izražaja dolazi čovjekovo odreknuće od Stvoritelja kao i onog što on nudi. Međutim, na teologija stvaranja ima svoje nužno upotpunjenje u teologiju otkupljenja (pashalni misteriji Isusa Krista) u kojem do svojeg vrhunca dolazi Ljubav pri čemu se upravo potvrđuje da Božja dobrota „nije neka neosobna fizička konstanta, nego trajna nastrojenost osobe s kojom čovjek stoji u odnosu i koju može sačuvati ili izgubiti“. 686

Također, nepreskočivim se, po pitanju zla i patnje u svijetu, nameće Aurelije Augustin, kojeg Welte na više mjesta u ovom kontekstu također spominje. Augustin u svojem djelu Ispovijesti piše sljedeće:

„Tako sam zamišljao tvoje ograničeno stvorenje, puno tebe neograničenoga, i govorah: Evo Boga i evo onoga što je Bog stvorio. Bog je dobar od svega toga mnogo i neizmjerno uzvišeniji. Pa ipak, jer je dobar, stvorio je dobra stvorenja: i eto kako ih okružuje i prožima! Gdje je dakle zlo, odakle je i kojim se putem ovamo uvuklo? Što mu je korijen i što je sjeme njegovo? Ili ga uopće nema? Zašto se dakle bojimo i čuvamo onoga što ne postoji? Ili ako se bez razloga bojimo, onda je sigurno ili sam strah zlo kojim se uzalud podbada i muči naše srce, i toliko je teže zlo koliko nema razloga da se bojimo, a ipak se bojimo. Dakle: ili postoji zlo kojeg se bojimo ili zlo to što se bojimo. Odakle je dakle zlo kad je sve ovo stvorio Bog, dobri Bog dobra stvorenja? Veće doduše i vrhovno dobro stvorilo je manja dobra, ali ipak je sve dobro: i Stvoritelj i stvorenja. Odakle dakle zlo? Je li možda ono od čega je ovo stvorio bila neka zla pratvar, pa ju je oblikova i uredio, ali je u njoj ostavio nešto što nije pretvorio u dobro? Ali zašto opet to? Je li možda bio nemoćan da ju svu okrene i promijeni da ništa zla ne ostane, on koji je svemoguć? Napokon zašto je od nje htio stvoriti nešto a nije radije svojom svemogućnošću

${ }^{685}$ Isto, str. 319.
${ }^{686}$ Isto. 
učinio da je uopće ne bude? Ili zar je mogla pasti protiv njegove volje? Ili ako je bila vječna, zašto ju tako dugo pustio da postoji takva kroz beskrajna vremena prošlosti i tek poslije toliko vremena odlučio da nešto od nje stvori? Ili ako je već nešto iznenada odlučio raditi, zašto nije radije, kao svemogući, učinio da ona ne postoji i da postoji on sam, sva istina i vrhovno neograničeno dobro? Ili ako nije bilo dobro da onaj koji je dobar nešto dobro i ne stvori i sazda, zašto nije uklonio i uništio onu zlu pratvar i na njezino mjesto postavio dobru od koje će sve stvoriti? Ne bi naime bio svemoguć kad ne bi mogao stvoriti nešto dobro bez pomoći one pratvari koju sam nije stvorio.“687

U kontekstu govora o zlu kao nedostatku dobra i kao jednom važnom teodicejskom pitanju do izražaja dolazi i patnja i trpljenje koje snalaze čovjeka te slobodna volja koja mu pripada. Patnja i trpljenje se sastoje od mnoštva individualnih trpljenja i patnji. Stoga, njezin smisao se može dohvatiti jedino unutar religijskog obzorja razumijevanja te stvarnosti. Autorica Aguti kaže kako je ovdje u pitanju „epistemička distanca između Boga i čovjeka, koja je posljedica božanske transcendencije te istodobno predstavlja jedan od nužnih uvjeta za izvršenje čovjekove slobodne volje“ 688

Iz svega do sada rečenog o ateizmu te teodicejskog problema postojanja zla u svijetu može se reći da za nevjernika i agnostika problem zla ne postoji kao neki gorući problem, oni su svjesni da zlo postoji, egzistira, a postojanje Boga kao savršenog i beskonačnog bića oni odbacuju. Njihov najsnažniji argument jest taj da bi postojanje Boga isključivalo mogućnost postojanja i činjenja zla u svijetu jer Bog ne bi dopustio patnju čovjeka u svijetu.

No, ono što se može reći iz Welteove kršćanske perspektive jest to da je postojanje zla do kraja nerazrješivo pitanje. Istina, Welte, na tragu tradicije pitanje zla općenito, razlikuje od tzv. moralnog zla, koje proizlazi iz ljudskih slabosti i grijeha koje čovjek čini. Zasigurno Bog ne želi da čovjek čini zlo i grijeh, ali postojanje slobodne volje čovjeku to omogućava. Bog stvara slobodna stvorenja koja svoju slobodu upravljaju prema svojoj volji. Vjernik se pouzdaje u Boga koji je tajnovit i nevidljiv, beskonačan i neizmjeran u svojoj dobroti i ondje gdje prestaje mogućnost čovjekova razumijevanja postojanja zla osoba koja je vjernik prihvaća s vjerom Božju dobrotu i svemoć. ${ }^{689}$ Potpuni smisao patnje i zla koje čovjek vjernik proživljava na ovom svijetu, očitovati tek u vječnosti.

\footnotetext{
${ }^{687}$ AUGUSTIN A., Ispovijesti, str. 133-146.

688 AGUTI, Filozofija religije. Povijest, teme, problemi, str. 269. i 323. Epistemička distanca spram Boga potrebna je radi slobodnog odabiranja između dobra i zla.

${ }^{689}$ Usp. PLANINIĆ J., Problem zla u svijetu, str. 359.
} 


\section{ZAKLJUČAK}

Teza doktorskog rada bila je pokazati Welteovo shvaćanje osobe i vjere u kontekstu promišljanja o religiji te pokazati kako je moguć dijalog i otvorenost, štoviše, suradnja između filozofije i teologije po pitanjima čovjekova postojanja koje je Welteovu fenomenologiju posebno obilježilo. Welteova filozofija religije polazi od čovjekova življenja religioznog odnosa, ostvarenja samog sebe, uzimajući na poseban način u obzir subjektivnost onog koji promišlja. Za Welteovu filozofiju temelj jest Bog, i to božanski Bog koji nije više nepoznati, skriveni Bog, nego živi Bog religije - koji živi među ljudima. ${ }^{690}$

Svoju filozofiju religije Bernhard Welte od 1949. godine naziva fenomenologijom religije zato što su mu se, kako i sam kaže, otvarali novi vidici u tumačenju vlastite mu filozofije, stoga je bilo prikladnije nazvati ju fenomenologijom religije. O fenomenologiji kod Weltea govorili su i Klaus Kienzler ${ }^{691}$ koji Welteovu fenomenologiju proziva religijskom fenomenologijom te Ingeborg Feige ${ }^{692}$ u doktorskom radu iz 1989. godine gdje piše o Welteovu shvaćanju fenomenologije i povijesnosti te osobe kao temelja od kojeg polazi. Iako pojam filozofije religije nikako nije nedostatan, uzeli smo u obzir sve što Welte govori te i mi krenuli tom linijom.

Welteova fenomenologija religije jest zapravo, ,iznašanje u pojavak svega onoga $s$ čime se susrećemo“ - nastojanje kako bi vjeru u okviru promišljanja o religiji učinio što više prihvatljivom i razumljivom. ${ }^{693}$

Welteova filozofska promišljanja započinju od Husserla i Heideggera pa do vlastite mu filozofije i fenomenologije religije. Welteova fenomenologija religije jest ona koja je crpila vrijednost iz Husserlove kako rane, tako i kasne fenomenologije. Od ranog Husserla Welte polazi od njegovih Logičkih istraživanja gdje se eidetska redukcija zbiva u tome da se reducira egzistencija svakog pojavnog predmeta svijesti, svjesnog predmeta i zadržava samo eidos, bit ili vid pojave koju jastvena svijest u intencionalnim aktima dovodi na vidjelo. ${ }^{694} \mathrm{Na}$ razini transcendentalne fenomenologije više nije bilo dovoljno zagraditi egzistenciju

\footnotetext{
${ }^{690}$ Usp. KUŠAR S., Spoznaja Boga u filozofiji religije. B. Welte i božanski Bog, Biblioteka Filozofska istraživanja, Zagreb,1996., str. 263.

${ }^{691}$ KIENZLER K., Religionsphänomenologie bei Bernhard Welte, u: Bausenhart G., Böhnke M., Lorenz D., Phänomenologie und Theologie im Gespräch. Impulse von Bernhard Welte und Klaus Hemmerle, Herder, Freiburg-Basel-Wien, 2013., str. 180-201.

${ }^{692}$ FEIGE I., Geschichtlichkeit: Zu Bernhard Weltes Phänomenologie des Geschichtlichen auf der Grundlage unveröffentlichter Vorlesungen, (Freiburger theologische Studien), Herder, Freiburg, 1989., str. 1-13.

${ }^{693}$ WELTE B., Filozofije religije, prev. Kušar S., uvod K. Kienzler, str. 11.

${ }^{694}$ SUTLIĆ V., Kako čitati Heideggera, uvod u problematsku razinu »Sein und Zeit«-a i okolnih spisa, August Cesarec, Zagreb, 1987., str 33-45.
} 
doživljaja, nego čitav prirodni stav spram svijeta (naturliche Welteinstellung), a svijest koja preostaje nije svijest naprosto, nego se u intencionalnim aktima, karakterističnim za svaku svijest, konstituira jastveni subjekt i svjesni predmet. ${ }^{695}$ Intencionalna analiza u drugoj fazi Husserlova mišljenja odnosi se na konstitutivne akte ne više svijesti uopće, nego omogućavajuće svijesti, transcendentalne svijesti u imanenciji bujice svijesti, svjesnog života, apsolutnog bitka. ${ }^{696} \mathrm{U}$ ovoj se fazi Welte povezuje s Husserlom tako da mu je posebno zanimljivo bilo njegovo tumačenje prirodnog stava spram svijeta te i on sam promatra osobu unutar svijeta i njezin stav i odnose koji se vode unutar tog životnog obzorja svijeta. U Husserlovoj fazi kasne fenomenologije, koju nazivamo životno svjetovna, on govori o svijetu kao horizontu horizonata - koji je svijet života (Lebenswelt), a tome je pisao u Krizi europskih znanosti. ${ }^{697}$ Ova fenomenologija kasnog Husserla jest ona koja premašuje tu spomenutu krizu i okreće se povijesnom mišljenju. U tom smislu za kasnog Husserla fenomenologija biva znanost o fenomenima - o samim stvarima na način na koji su nam dane - sve se stvari razlikuju u načinima danosti, no ipak fenomenologija pokazuje njihovo jedinstvo i istinu pa se i sam svijet pokazuje kao horizont horizonata. Horizont horizonata jest pojam koji Welte preuzima, no pomalo preoblikovan, i naziva ga obzorjem svijeta što zapravo znači da osoba vlastitim izvršenjem biva sposobna razviti i dati na značaju, posebice odnosu između ,ja“„ti““, to jest osobnim odnosima koji pripadaju obzorju svijeta i u tome se rasvjetljava bitak bića kao takvog koji opet vodi k Onom vječnom „Ti““.

Kada se radi o Heideggeru i njegovoj egzistencijalnoj fenomenologiji koja je imala zadaću vratiti se bitku, možemo kazati kako, prema Heideggeru, biću pripada to da je otkriveno i njegova je vrsta bitka razumljena, to jest raskrivena. Fenomenologija se, prema Heideggeru, bavi propitivanjem onog što se pojavljuje u doživljaju i što je umu samorazumljivo te upravo u tome leži njezina vrijednost jer se bavi propitivanjem temelja. Podsjetimo se samo kako je Heidegger cjelokupnoj zapadnoj metafizici zamjerio zaborav bitka jer je sve bilo usmjereno na biće kao prisutno bivstvujuće. Zato Heidegger promišlja o tubitku. Tubitak jest način bitka čovjekova i označava opstanak (Dasein) ili tubitak. Bit je tubitka sloboda, a težište mu je egzistencijalna odlučnost. Smatramo kako je upravo ovo Heideggerovo promišljanje o tubitku poslužilo za Welteovo predavanje iz 1966. godine gdje on piše o odlučnosti i slobodi, a započinje s razmatranjem osvjetljavanja tubitka. Prvi dio

\footnotetext{
${ }^{695}$ Isto, str. 33-45.

${ }^{696}$ Isto.

${ }^{697}$ Usp. ZAHAVI D., Husserls Phänomenologie, prev. Obsieger B., Mohr Siebeck, Tübingen, 2008., str. 131139.
} 
doktorskog rada govori o Osobi (Gesammelte Schriften I/1), prema Welteovim predavanjima od 1966. do 1978. godine koja su održana na Sveučilištu u Freiburgu. Upravo je prema svojoj duhovno-umskoj komponenti osoba za Weltea bitno drugačija od svega postojećeg. Osoba posjeduje supstancijalnost - što znači biti u sebi i po sebi i da je samostojno biće; racionalnost koja označava razumsku komponentu i slobodu prema kojoj osoba djeluje svrhovito, slobodno i odgovorno; te individualnost - što znači da je osoba individuum i označava sastavljenost $\mathrm{u}$ jednoj cjelini i da osoba opstoji na jedinstven način - jedinstvena je, nepriopćiva i različita od drugih ljudi. Posebno važnim za tumačenje osobe u Weltea jest susret i suživot s drugim ljudima koji se odvija na temelju razgovora, jezika, svijeta te općenito kršćanstva. Dijalog od osobe koja sam ja prema osobi koja je označena sa $t i$ odvija se upravo u razgovoru i kroz razgovor, susret, a kršćanstvo je, prema Welteu, okvir tog susreta. Osoba je, prema Welteu, jedna dinamična, otvorena struktura, nikako statična, koja posjeduje slobodu i odgovornost, a ostvaruje se kroz dijalog i susret među ljudima; ovdje se posebno važna čini i Buberova dijalogika odnosa ,ja“-,„ti“. Živi je susret jasan pokazatelj karaktera neke osobe pri čemu su odgovornost i moralnost bitne za susret. Kada se radi o jeziku, jezik je temeljni način ophođenja s drugim i s Bogom. A kršćanstvo je ondje gdje osoba, upuštajući se u avanturu kršćanske vjere, sebe nužno transcendira i u konačnici otkriva istinu o samoj sebi.

Spomenuti Welteov spis iz 1966. godine naziva Odlučnost $i$ sloboda govori o izvršenju religije koju moralno područje i savjest potiču. Za savjest je potrebna odlučnost, odvažnost. U ovom kontekstu Welte spominje i Augustina koji u govoru o savjesti kao slobodi posebno ističe odgovornost čovjekovu za dobro i zlo koje čini. Sam govor o savjesti dolazi iz stoičko-kršćanske tradicije gdje je sineidesis - suznanje koje je kasnije Ciceron nazvao Constientia. Savjest kao sineidesis dolazi kroz suznanje u svijesti te je svijest o vlastitom moralnom činu.

Drugi vatikanski koncil govori o Dostojanstvu ljudske osobe - gdje je čovjek označen kao slika Božja i to je ishodište za govor o dostojanstvu ljudske osobe kod Weltea. Dostojanstvo ljudske osobe temelji se na dužnosti pojedinca u potrazi za istinom (ljudska prava, individualna sloboda i dostojanstvo). Welte donosi još jedan pojam, humaniziranje svijeta - pobijediti ravnodušnost i smisleno oblikovati sadašnjost. Istinski je humanum nešto specifično ljudsko, plod ljudskog duha. Povezan je sa slobodom jer čovjek kao slobodno i racionalno biće posjeduje moralnost, savjest, pravednost. Još jedan bitan pojam za Weltea jest pojam nade koji se tiče ljudskog postojanje uopće i znači življenje u napetosti prema nekom 
ostvarenju. Čovjek koji gaji nadu nikad nije na gubitku. O nadi kod Weltea piše spomenuti Ingeborg Feige govoreći o nadi kao povijesnoj istini i o apriornoj strukturi onog čemu se nadamo. ${ }^{698}$ Naravno, misli se upravo na nadu kao ono što prethodi iskustvu pojedinca. Prvo je nada, a tek onda iskustvo onog proživljenog.

Nadu se, prema Welteu, može označiti i vrlinom koja utječe na naš život, karakter te usmjerava naše postojanje. Vrlina kao moralna izvrsnost osobe vezana je uz ljudsko postojanje - oduvijek prisutna u čovjeku i potiče i istinski strah Božji, no strah lišen tjeskobe, napuštenosti i neuspjeha. Ovdje Welte kratko spominje Aristotela i njegovo tumačenje vrline koji donosi eudajmonističko shvaćanje vrline koja označava s jedne strane konačno dobro (težimo k njima zbog njih samih) i instrumentalno dobro (gdje težimo i idemo prema sreći). Razboritost (fronesis) je ključna vrlina koja izgrađuje karakter. Još jedan od autora kojeg Welte spominje u kontekstu nade jest Toma koji kaže kako nada dolazi od Boga i čovjeka vodi k beskrajnom dobru. Ona je, naravno, i čuvstvo i nadnaravna krepost koja čovjeka osposobljava za postizanje vječne sreće. Paradoks nade jest u tome što ona nije sama po sebi dana i za njezino je ostvarenje potrebno i odricanje.

Nadalje, kada se radi o strahu kao fenomenu koji Welte usko vezuje uz pojam osobe, treba reći kako je strah zapravo nedostatak smislenosti u životu osobe - pojedinca, pri čemu se strah od života pretvara u složenije stanje, naime, tjeskobu svojevrsne bez-temeljnosti. Tjeskoba je, prema Welteu, nešto što uznemiruje našu svijest. Stoga zahtjev za smislenošću jest poreduvjet smislene budućnosti, a pojam nade i biblijski pojam pouzdanja jest ono što čovjeka može vratiti vjeri u Onoga koji je veći od svake čovjekove ograničenosti i manjkavosti. Welte ovdje donosi pojam hrabrost za strah koji zapravo u sebi uključuje i povjerenje i nadu.

Povjerenje je ono koje oživljava i obnavlja, a nada kao pouzdanje daje snagu, krijepi i jača. U kontekstu govora o strahu Welte spominje sljedeće autore: Hegela, Kafku, Kierkegaarda i Heideggera. Kafka je poznat po svom izričaju „ne bojim se, ali me je strah“. Hegel o strahu govori kao o strahu od istine, rađa se ondje gdje pojedinac neumorno traga za istinom. Taj negativni strah Hegel naziva i nerazumnim, no pogledati strahu u oči omogućuje istinu o strahu jer je suočavanje sa strahom moguće na način uzmicanja. Strah je za Kafku svakidašnja pojava koja čovjeka ograničava u njegovoj slobodi. Kierkegaard za strah kaže kako u samoj čovjekovoj mogućnosti djelovanja možemo pronaći razlog za strah. U njegovu

698 Usp. FEIGE I., Geschichtlichkeit: Zu Bernhard Weltes Phänomenologie des Geschichtlichen auf der Grundlage unveröffentlichter Vorlesungen, str. 311-315. 
djelu Ili-Ili pronalazimo stupnjeve mogućnosti postojanja koji su estetski (bezbožno, egocentrično), etički (ispunjen osjećajem dužnosti) i na najvišem stupnju religiozni stupanj koji je ispunjen patnjom kao priprema za vječnost. Prema Kieregaardu, čovjek koji ništa ne misli biva slobodan od svega. Heidegger razlikuje Angst (strah) i Furcht (bojazan). Za Heideggera je strah jedan modus čuvstvovanja (Empfindlichkeit). Samo onaj kojem je stalo do njega samog može strahovati. To je pozitivni segment straha. Iz ovog proizlazi kako je strah uvijek vezan uz buduće - uz ono što će doći. Čovjek je za Heideggera egzistencijalna mogućnost, ne zna odakle dolazi ni kamo ide, a ništavost je ta koja izaziva strah.

Strah je u sferi onostranog. Budući da sam stvoren od Ništa, ono uvijek prijeti da me pozove k sebi. U kontekstu straha Welte spominje i Pascala i njegovu okladu gdje on zaključuje kako je Bog - ako postoji -nužno nedokučiv. Svojom okladom želi potaknuti čovjeka da donese nužno egzistencijalnu odluku gdje je dobitak uvijek veći od eventualnog gubitka. Bog postoji ili ne postoji. Čovjek je, prema Pascalu, dijalektičko biće koje svoj potpuni smiraj može pronaći jedino u živom Bogu Objave.

Još jedna tema kojom se Welte pozabavio u prvom dijelu rada, a kada se radi o osobi, jest tema igre gdje su igre oduvijek imale važnu ulogu u okviru ljudskog postojanja. Welteovo predavanje o Postojanju u simbolu igre iz 1982. godine donosi sijedeće zaključke o igri: 1. igra pruža drugačiji poredak stvarnosti - lakoća i neopterećenost; 2. igra je simbol života lakše podnošenje ozbiljnosti i težine života; 3. igra je i arhetipska osnova života - jer se odnosi na sve što činimo u životu, još od mladih dana.

Toma Akvinski, kojeg Welte u ovom kontekstu spominje za igru, kaže kako je ona koja raduje - njezino djelovanje ima svrhu u samoj sebi bez nekog posebnog cilja. Welte razlikuje igru trostruko: 1. igre na sreću, 2. borbene ili natjecateljske igre te 3. čista igra. Igre na sreću su takozvano „prizivanje sreće“, čovjek oduvijek teži za srećom. Ljudi suvremenog doba često postaju igrači sreće jer žive rizik potrage za srećom. No ove igre sa sobom nose i određeni rizik pri čemu se osobe igraju sa slučajnošću za kojom istovremeno žude i strahuju od ishoda. No, prema Welteu, to i je tajna rizika igre u kojoj ljudi toliko uživaju. Natjecateljske su igre one koje imaju borbu i rivalstvo kao odlučujući faktor, odnosno napor suparničkih protivnika dolazi do izražaja kako bi se postigao uspjeh i što bolji rezultat. U ovim se igrama ljudi služe svojim naporima i vještinama, a manje se oslanjaju na sreću. Welte će reći kako upravo igra uči horizontu legitimnog sukoba, a tome u prilog govori činjenica da se rivalstva razvijaju i na drugim područjima ljudskog života. Borbene igre imaju i poseban odnos ili poveznicu s pojmom mita koji predstavlja događaj kao simbol onoga što se iznova 
događa - timska igra, a pobjednik se zna tek naknadno, nakon završetka iste. Čista je igra, prema Welteu, jedna od najdubljih i najtajanstvenijih igara. Posebice Welte ovdje ističe glazbu. Glazba, prema Welteu, proizlazi iz čistog podrijetla i zrači nekim posebnim sjajem. U čistoj igri, reći će Welte, nema nereda ili samovolje, zato u ovom kontekstu spominje Hegela i bakanatski zanos - što je zapravo metafora za ono istinito. Bakho je simbol vječnog života, rasta, neprestanog obnavljanja, produhovljenja, ali i razaranja u svrhu oslobođenja te integriranja suprotnosti. Welteovim riječima, glazba uvijek predstavlja zanos i unutar nje je prisutan uvijek svečani trenutak, ona sama jest neka vrsta svečanosti prožete igrom. Tišina je usko vezana uz glazbu te svaka ozbiljna glazba ima i svoj vid tišine. To znači zapravo razotkrivati ono skriveno/neskriveno glazbe kao glazbe. Njezina zagonetnost izmiče svim znanstveno-teoretskim promatranjima, već se osluškivanjem kreće u obzorju nepojmljivoga. Ovdje uviđamo kako Welte kroz ovakvo shvaćanje glazbe kao čiste igre aludira na vječnost.

Osvjetljavanje je tubitka još jedna tema kojoj Welte posvećuje dio promišljanja u razmatranju pojma Osobe. Osvjetljavanje tubitka jest pojam kojim Welte označava osobu koja postaje svjesna same sebe, drugoga kojeg prepoznaje na tom putu i oslovljava ga sa $t i$, svog svijeta i boravi u percepciji vlastita postojanja. Pojam tubitka Welte preuzima od Heideggera koji je način bitka čovjeka nazvao opstankom (Dasein) ili tubitkom. Bit je tubitka sloboda, a težište odlučnost. Samosvijest je, prema Welteu, ono što on naziva spona tubitka, a što označava svijest o vlastitom postojanju i egzistenciji. Sličnosti između Weltea i Heideggera idu u smjeru isključivanja znanosti kako bi ono jesam bila istinska potvrda ljudskog postojanja koju osoba prepoznaje u odnosu ,ja“ - „ti“. Kušar za relaciju ,ja“ - „ti“ kaže kako upravo ona otvara perspektivu u kojoj spoznajemo totalitet čovjekova bivanja u odnosu prema transcendentnom smislu. Tragovi se transcendentnoga pokazuju kroz slobodu, nadu, ljubav i čovjekovu duboku upućenost na smisao. ${ }^{699}$ Metoda koja čovjeka vodi k dubljem shvaćanju njegova vlastita bića i upućuje čovjeka k vjeri u Boga ima tri obilježja: 1 . egzistencijalna - polazi od življenog čovjekova iskustva opstojanja; 2. fenomenološka otkriva stvarnost egzistencije; 3. transcendentalna - izlaganje ontoloških pretpostavki potrebnih za razvijanje iskustva koje se očituje u fenomenu egzistencije. ${ }^{700}$

Za Weltea je osoba uvijek duhovno biće - koja kroz svoju duhovnu dimenziju biva označena kao vrijednost, a obzorje svijeta kao pojam koji posjeduje osoba znači da osoba vlastitim izvršenjem razvija bitak cijelog svijeta (osobe su same sebi pripadajući iskoni, one

\footnotetext{
${ }^{699}$ Usp. KUŠAR S., Tragovi transcendentnoga (II. dio), u: Obnovljeni život, 49 (1994) 5, str. 473-474.

${ }^{700}$ Isto, str. 296-298.
} 
potpadaju pod sklop odnosa iskona $\mathrm{s}$ iskonom te kao takve ostvaruju smisao i značajnost svijeta, a time i značajnost sveg bića u cjelini).

Kada se radi o metafizičkoj konstituciji ljudske osobe, prvo treba spomenuti Boetijevu definiciju od koje i sam Welte polazi, a koja kaže kako je osoba individualna supstancija razumske naravi.

Toma je govorio o duši i tijelu koje predstavljaju dva načela iz kojih nastaje jedno realno postojeće biće. Individualnost osobe govori o tome da je osoba konkretno, a ne univerzalno biće. Racionalnost osobe govori o tome da osoba posjeduje razumsku spoznajnu moć. U čovjeku je prisutan jedinstven spoj duše i tijela koji konstituira ljudsku osobu. Fenomenološko određenje osobe određuje osobu kao onu koja postoji i djeluje u svijetu u kojem živi. Vrijednosno određenje osobe znači da osoba ima vlastito joj dostojanstvo, vrijednost, originalnost i jedinstvenost. Čovjek je biće slobode i biće religije te se samo u osobnoj slobodi i kroz osobnu slobodu može govoriti o osobnom odnosu i u konačnici odluci za Transcendenciju - u tome se sastoji ono što Welte naziva slobodno izvršavanje religije.

U drugom dijelu rada bavili smo se „vjerom“ koja je uz osobu jedna od glavnih tema koju je trebalo prikazati u filozofiji i fenomenologiji religije B. Weltea. Ovdje je bila riječ o Welteovoj fenomenologiji religije koja proizlazi iz njegovih freiburških predavanja održanih od 1962. do 1973. godine. Filozofija religije s Bernhardom Welteom, zaključili smo, zadobiva sasvim novo obzorje kojim se počinje prepoznavati kao fenomenologija religije.

Fenomenologija religije za našeg autora predstavlja iznašanje u pojavak sveg onog $\mathrm{s}$ čime se susrećemo. Upravo smo u drugom poglavlju ovog dijela rada uočili svu prožetost Welteove filozofije religije fenomenologijom. Ona (fenomenologija religije) se bavi prvenstveno religijskim fenomenima s kojima se osoba u svojem ljudskom postojanju susreće i u okviru kojih živi i djeluje - otvaranje novih vidika. Stoga Welte svoju filozofiju religije naziva fenomenologijom religije. Zadaća je fenomenologije religije pokazati uzajamnost sa svim drugim znanostima koje se bave religijskim životom. U govoru o fenomenologiji potrebno je reći kako su na Weltea posebno utjecali Husserl i Heidegger. Husserl i njegova kasna fenomenološka misao gdje govori o upućenosti stvari na svijet - o pojmu svijet života Lebenswelt. Heidegger o fenomenologiji progovara kao o onoj koja se bavi propitivanjem onog što se pojavljuje u doživljaju i što je umu samorazumljivo. Bavi se propitivanjem 
temelja i u tome leži njezina vrijednost. Zadatak fenomenologije jest vratiti se bitku. Biću pripada to da je otkriveno i njegova je vrsta bitka razumljena - raskrivena.

Nadalje, u govoru o Bogu Welte zaključuje kako je Bog prvotni začetnik religije te zaslužuje biti mišljen u svjetlu metafizičke tradicije mišljenja - ali još više da bude u iskustvu dodirnut i zazvan - onkraj metafizičkog mišljenja. ${ }^{701}$ Welteova misao o Bogu donosi sa sobom promišljanje trostruke razlike: 1 . ontološke - gdje se Welte osvrće na misao Karla Jaspersa i Tome Akvinskog (kod Tome, kao i kod Jaspersa, nije moguće pozitivno shvatiti i izreći tu puninu koja Transcendencija, bitak sam ili Bog jest - jer se uvijek pokazuje ponad i onkraj bića, nepredstavljeno i neraspoloživo, samom sebi pridržano ${ }^{702}$ ), 2. fenomenološke koja vodi $\mathrm{k}$ analizi čovjekova postojanja u svijetu; ovdje je posebno izražena misao o bezuvjetnosti i nadmoći transcendentne zbilje koja se čovjeku otvara; sve to dovodi čovjeka i do religijskih simbola za koje Welte kaže da uprisutnjuju božanskog Boga; Bog na taj način potiče čovjekovo ponašanje ${ }^{703}$, 3. teološka - polazi od Boga prema čovjeku koji se nalazi pred Bogom; ona se pokazuje u izvršenju religioznog odnosa - vjerovanju u Boga, molitvi i kultu. Okret čovjeka prema božanskom Bogu uvijek je duboko osobno događanje i nije ga moguće primjereno predmetno opisati. ${ }^{704}$

Nazivi su za Boga kod Weltea uvijek negacije, a svrha je bila dotaknuti neizrecivu puninu - beskonačno, bezuvjetno i ono ništa. U ovom dijelu rada spominjemo i Meister Eckharta koji je Welteu bio zanimljiv zbog svojih promišljanja, posebice o putu odijeljenosti i tamnom svjetlu božanstva. Put odijeljenosti i ono što se na njemu zbiva i postiže samo po sebi jest religiozno događanje - događanje religije. ${ }^{705}$ Eckhartu je nastojanje bilo da u odijeljenosti opiše i potakne traženje posebnog religioznog oblika života te novog i izvanrednog iskustva Boga i svijeta koji njemu pripada. Iskustvo onoga Ništa kod Weltea vodi k tome da on donosi dva puta prema Bogu: 1. na Welteovu prvom putu ono ništa jest u ljudskom iskustvu pokazatelj da je misao zakoraknula preko razine metafizičkog mišljenja - tu se pokazuju konture apsolutne tajne koja daje svemu smislenost - radi se o Bogu; 2. put se pokazuje kao razlika između konačnog (potrebujućeg) bića i apsolutne tajne koja svemu jamči

\footnotetext{
${ }^{701}$ Usp. KUŠAR S., Spoznaja Boga u filozofiji religije. B. Welte i božanski Bog, str. 263-264.

702 Isto, str. 295.

703 Isto, str. 298.

704 Isto, str. 301.

${ }^{705}$ Isto, str. 276.
} 
utemeljenost, odnosno odlučnost bića u njegovu bitku. ${ }^{706}$ Bog je u Welteovu mišljenju Tajna kojom je čovjek pogođen, a ne posjeduje ju. ${ }^{707}$

Nadalje, u govoru o religiji treba poći od samog pojma religije koja predstavlja organizirani sustav vjerovanja i bogoslužja, a vjera je osobni stav pojedinca. Različiti su modeli vjere, a Welte ih spominje nekoliko: 1. kvaliteta mora iskoračiti ponad kvalitete, to je ono pozitivno pripadno svakom pojedincu, 2. model je onaj međuljudski i Welte ovaj model iznačava kao ono „ti“ susreta - za to je potrebna odvažnost samog susreta. Čovjek je za Weltea onaj koji je izvršitelj religije. Načini izvršenja religije jesu molitva šutnje (negativnost kao odijeljenost, pozitivnost kao sabranost, pobožnost i preokret zahvale), molitva govora (oslovljavanje Boga, afirmacije o Bogu, simbolički govor, klanjanje, hvala, zahvala, molba) koja ima teološki i antropološki pol (govori Bogu i govori čovjek), molitva kulta koja se dovršava u molitvi kao govoru.

Welte donosi zahtjev kako treba čuvati religiju i religioznost od izopačenosti koje su posebice vidljive u umnažanju vanjskog izražaja religije, religije kao ideologije i religioznog fanatizma. S tim u vezi pojavljuje se kod Weltea govor o ateizmu. Kada se radi o fenomenu ateizma, Welte ga razlikuje trostruko: kao negativni (orijentira se na prisutno bivstvujuće, pojedinac neopterećen mišlju o Bogu, totalitariziranje znanosti, radikalni izostanak transcendencije), kritički (Bog činjenica, želja za ovladati svime) i pozitivni ateizam (volja koja hoće sve znati, ne skriva svoju ne misao o Bogu).

Govor o teodicejskom pitanju i postojanju zla u svijetu posljednji je dio doktorskog rada, a govori o tome da će se potpuni smisao patnje i zla u svijetu koje čovjek proživljava očitovati tek u vječnosti. To je pitanje moguće razriješiti jedino u bezuvjetnoj Tajni samog Boga.

Welte je zasigurno onaj mislilac koji od početnog metafizičkog promišljanja dolazi do božanskog Boga i svoje mišljenje koje ide ususret vjerovanju pomiruje s filozofijom te otvara mogućnost daljnje komunikacije i dijaloga između filozofije i teologije, između Boga koji se kod Heideggera pokazuje kao odsutan, dalek Bog koji dolazi i odlazi prema svojoj volji, i božanskog Boga koji se približava čovjeku, kojeg čovjek može zazvati i moliti i od kojeg u konačnici dobiva odgovor.

\footnotetext{
${ }^{706}$ Isto, str. 211-226.

${ }^{707}$ Isto.
} 


\section{Literatura}

AFRIĆ V., Uvod, u: Revija za sociologiju, 34 (2003) 1-2, str. 3-7.

AGUTI A., Filozofija religije. Povijest, teme, problemi, KS, Zagreb, 2017.

AKRAP A., Fenomenologija prisutnosti. Apsolutno, religija i filozofija u misli Martina Bubera, u: Bogoslovska smotra = BS, 85 (2015) 4, str. 979-1005.

AKVINSKI T., Suma protiv pogana, sv. I., KS, Zagreb, 1993.

AKVINSKI T., Suma protiv pogana, sv. II., KS, Zagreb, 1993.

AKVINSKI T., Summa theologica II-II, q. 168, a. 2-4.

AKVINSKI T., Summa theologica, II-II, q. 17, a. 2.

ALBERT H., Traktat über Krtisiche Vernunft, Mohr Siebeck, Tübingen, 1969.

ARBANAS D., Kozmološki putovi Tome Akvinskog i Tillichovo poimanje kozmološkog tipa filozofije religije, u: FI = Filozofska istraživanja, 34 (2014) 1-2, str. 181-195.

ARISTOTEL, Metafizika, prev. Gavela B. B., Kultura, Beograd, 1971.

AUGUSTIN A., Ispovijesti, prev. Bajsić V., KS, Zagreb, 2012.

AUSTIN J. L., Zur Theorie der Sprechakte, Reclam Verlag, Stuttgart, 1972.

BAJSIĆ V., Neki problemi filozofskog prilaza religiji, u: FI, 9 (1989) 1, str. 5-13.

BEER-SHEVA, Kierkegaard: Kako domišljat teolog nalazi nesreću, prev. Bertman M. A., u: FI, 9 (1989) 1, str. 125-132.

BERDJAJEV N. A., Ja i svijet objekata, prev. Thaller N., KS, Zagreb, 1984.

BERDJAJEV N. A., O čovekovu ropstvu i slobodi, prev. Jovanović Lj., Književna zajednica Novog Sada, Novi Sad, 1991.

BERNHARD C., Die Unfähigkeit zur Gottesfrage im positivistischen Bewußtsein, Herder, Freiburg, 1972.

BIRNBAUM N., Die Religon in Geschichte und Gegenwart, sv. 3, Paul Siebeck Verlag, Tübingen, 1959.

BLOCH E., Ateizam u Kršćanstvu, prev. Šarinić H., Naprijed, Zagreb, 1986.

BLOCH E., Princip nada I-III, prev. Šarinić H., Naprijed, Zagreb, 1981.

BOCHENSKI J. M., Uvod u filozofsko mišljenje, Verbum, Split, 1997. 
BORŠ V., Istinito kao bakanatski zanos: uloga i važnost pluriperspektivizma u Hegelovoj misli, u: FI, 36 (2016) 4, str. 775-785.

BOŠNJAK B., Povijest filozofije I-III, Matica hrvatska, Zagreb, 1993.

BRLOBUŠ K., Tišinom ugođena zagonetnost glazbe, u: FI, 142 (2016) 2, str. 221-236.

BROZOVIĆ D., KOVAČEC A., RAVLIĆ S., Hrvatska enciklopedija, mrežno izdanje, Leksikografski Zavod Miroslav Krleža, Zagreb.

BUBER M., Gottesfinsternis. Betrachtungen zur Beziehung zwischen Religion und Philosophie, Manesse Verlag, Zürich, 1953.

BULTMANN R., Die Krisis des Glaubens, u: Krisis des Glaubens - Krisis der Kirche Krisis der Religion: drei Marburger Vorträge, Giessen, 1931.

BULJAN I., Problem postajanja pojedincem u djelu Sørena Kierkegaarda, u: FI, 28 (2008) 2, str. 277-302.

CASPER B., Sprache und Theologie. Eine philosophische Hinführung, Herder, Freiburg i.Br., 1975.

CORETH E., Smisao čovjekove slobode, u: Obnovljeni život: časopis za filozofiju i religijske znanosti 53 (1998) 4, str. 391-402.

ĆUK B., Anselmov unum argumentum, u: BS, 82 (2012) 1, str. 65-89.

DODLEK I, Buberova filozofija dijaloga i umjetnost kao susret, u: FI, 33 (2013) 1, str. 83-95.

DOGAN N., U potrazi za Bogom. Kršćanin u postmodernom vremenu, Teologija u Đakovu, Đakovo, 2003.

DRUGI VATIKANSKI KONCIL, Deklaracija Dignitatis Humanae ili o vjerskoj slobodi, KS, Zagreb, 2002.

DRUGI VATIKANSKI KONCIL, Pastoralna konstitucija o Crkvi u suvremenom svijetu, Gaudium et spes, KS, Zagreb, 1980.

DRUGI VATIKANSKI KONCIL, Pastoralna konstitucija o Crkvi u suvremenom svijetu, Gaudium et spes, KS, Zagreb, 1980.

DUGANDŽIĆ I., Strah u svjetlu Biblije, u: BS, 73 (2003) 4, str. 619-630.

EBELING G., Einführung in die theologische Sprachlehre, Mohr Siebeck Verlag, Tübingen, 1971.

EBELING H., Meister Eckhart Mystik. Studien zu den Geisteskämpfen um die Wende des 13. Jahrhunderts, Stuttgart, 1941. 
ECKHART M., Deutsche Predigten und Traktate, Carl Hanser Verlag, München - Wien, 1963.

ECKHART M., Die deutschen und lateinischen Werke, u: Die Deutschen Werke, prev. Quint J., sv. 1., Stuttgart, 1958.

ECKHART M., Knjiga božanske utjehe - traktati i propovijedi, prev. Šoljić A., Naprijed, Zagreb, 1991.

ENDERS M., Meister Eckhart und Bernhard Welte. Meister Eckhart als Inspirationsquelle für Bernhard Welte und für die Gegenwart, LIT Verlag, Berlin, 2015.

FEIGE I., Geschichtlichkeit: Zu Bernhard Weltes Phänomenologie des Geschichtlichen auf der Grundlage unveröffentlichter Vorlesungen (Freiburger theologische Studien), Herder, Freiburg, 1989.

FEUERBACH L., Das Wesen Christentums: Vollständige Ausgabe mit Anhang und Fußnoten, Holzinger, Berlin, 2016.

FILOZOFSKI LEKSIKON, ur. Kutleša S., Leksikografski zavod Miroslav Krleža, Zagreb, 2012.

FINK E., Operative Begriffe in Husserls Phänomenologie, u: Nähe und Distanz, Alber, Freiburg - München, 1976.

FROMM S., Wittgensteins Erkenntnisspiele kontra Kants Erkenntnislehre, Symposion Alber, Freiburg, 1996., str. 267.

GARDAVSKY V., Gott ist nicht ganz tot, Chr. Kaiser Verlag, München, 1968.

GEIGER M., Beiträge zur Phänomenologie des ästhetischen Genusses, u: Jahrbuch für Philosophie und phänomenologische Forschung, sv. 1, 1913.

GROZDANOV Z., Teološki put Jürgena Moltmanna, u: Z. Grozdanov (ur.), Bog pred Križem, Zbornik u čast Jürgena Moltmanna, Rijeka, 2007., str. 211-231.

GUARDINI R., Mondo e persona, Morcelliana, Brescia, 2000.

HALDER A., Filozofijski rječnik, prev. Sesar A., Naklada Jurčić, Zagreb, 2002.

HEGEL G. W. F., Vorlesungen über die Philosophie der Religion I/1, ur. Lasson G., Philosophische Bibliothek, Hamburg, 1966.

HEGEL G. W. F, Fenomenologija duha, prev. Kangrga M., Naprijed, Zagreb, 1987. 
HEGEL G. W. F., Vorlesungen über die Philosophie der Geschichte, Philipp Reclam, Leipzig, 1910.

HEIDEGGER M., Bitak $i$ vrijeme, prev. Šarinić H., Naprijed, Zagreb, 1985.

HEIDEGGER M., Die onto-theologische Verfassung der Metaphysik, u: Identität und Differenz, Pfullingen, 1957, 35-73.

HEIDEGGER M., Kraj filozofije i zadaća mišljenja, prev. Brkić J., Naprijed, Zagreb, 1996.

HEIDEGGER M., Prolegomena za povijest pojma vremena, ur. Mikulić B., Demetra, Zagreb, 2000.

HEIDEGGER M., Što je metafizika?, prev. Kordić I., Institut za filozofiju, Zagreb, 2015.

HEILER F., Das Gebet: eine religionsgeschichtliche und religionspsychologische Untersuchung, München, 1920.

HÖRGL C., RAUH F., Die Botschaft von Gott und unser Glaube, u: HÖRGL C. i RAUH F., Grenzfragen des Glaubens. Theologische Grundfragen als Grenzprobleme, Zürich - Köln, 1967., str. 477-511.

HÖRGL C., RAUH F., Dualität und Einheit von Materie und Geist, u: HÖRGL C. i RAUH F., Grenzfragen des Glaubens. Theologische Grundfragen als Grenzprobleme, Zürich - Köln, 1967., str. 43-52.

HUSSERL E., Ideen zu einer reinen Phänomenologie und phänomenologischen Philosophie, M. Niemeyer, Tübingen, 1980.

HUSSERL E., Kartezijanske meditacije II., Prilog fenomenologiji intersubjektivnosti, prev. Zenko F., Centar za kulturnu djelatnost Saveza socijalističke omladine, Zagreb, 1976.

INGARDEN R., Nine Essays in Phenomenology, Springer, Netherlands, 1959.

JASPERS K., Philosophie (zweite, unveränderte Auflage), Springer Verlag, Berlin Göttingen - Heidelberg, 1948.

JELKIĆ V., Kraj povijesti ili nova epoha?, u: Metodički ogledi, 15 (2008) 2, str. 79-85.

JEVTIĆ N., Iskušenje ironije. Može li ironija igrati ulogu kritike?, u: FI, 33 (2013) 2, str. 229-241.

JUNG W., Hoffnung, u: PRECHTL P. und BURKARD F.P., Metzler Philosophie Lexikon. Begriffe und Definitionen, Verlag J. B. Metzler, Stuttgart - Weimar, 1996. 
KALAŠEVIĆ G., Kafkino hrvanje sa strahom, filozofsko-teološki pokušaji, u: Počeci, 4 (2003) 1, str. 6-23.

KALUĐEROVIĆ Ž., Stagiraninova aitiologija, u: Znakovi vremena, 16 (2013) 59, str. 73-92.

KANT I., Kritika čistog uma, prev. Sonnenfeld V. D., Nakladni zavod Matice hvatske, Zagreb, 1984.

KARLIĆ I., Teološki put Jürgena Moltmanna, u: Diacovensia, 25 (2017) 4, str. 639-653.

KERN U., Rezeption Eckharts im Protestantismus, u: Meister Eckhart und Bernhard Welte. Meister Eckhart als Inspirationsquelle für Bernhard Welte und für die Gegenwart, LIT Verlag, Berlin, 2015.

KIENZLER K., Religionsphänomenologie bei Bernhard Welte, u: Bausehart G., Böhnke M., Lorenz D., Phänomenologie und Theologie im Gespräch. Impulse von Bernhard Welte und Klaus Hemmerle, Herder, Freiburg-Basel-Wien, 2013.

KIERKEGAARD S., Der Begriff Angst. ur. Richter L., Reclams Universal-Bibliothek, Hamburg-Berlin, 2002.

KIERKEGAARD S., Die Schriften über sich selbst, ur. Hiersch E., Gütersloher Verlagshaus, Bad Birnbach, 1998.

KIERKEGAARD S., Philosophische Brosamen und Unwissenschaftliche Nachschrift, ur. Diem H. i Rest W., Köln-Olten, 1959.

KIERKEGAARD S., Strah i drhtanje, Verbum, Split, 2001.

KONGREGACIJA ZA NAUK VJERE, Naputak o nekim bioetičkim pitanjima, Dignitas personae / Dostojanstvo života (8. rujna 2008.), KS, Zagreb, 2009., br. 7.

KONGREGACIJA ZA NAUK VJERE, Naputak o nekim bioetičkim pitanjima, Dignitas personae / Dostojanstvo života, KS, Zagreb, 2009.

KOPREK I., Filozofsko promišljanje o strahu, u: Strah - naš životni pratilac, ur. Valentin Pozaić, FTI - centar za bioetiku, Zagreb, 1995., str. 166.

KOPREK I., Sreća i igre na sreću. Etički okvir za razumijevanje jednog fenomena današnjice, u: Nova prisutnost, 11 (2013) 3, str. 367-377.

KORFF W., Wie kann der Mensch glücken? Perspektiven der Ethik, München - Zürich, 1985., str. 388.

KOZELJ I., Savjest, FTI, Zagreb, 1990., str. 203. 
KRIBL J., Problemi dobra i zla u etici N. Berdjajeva, u: BS, 47 (1977) 1, str. 88-101.

KUSIĆ A., Dva aspekta suvremenog egzistencijalizma, u: Crkva u svijetu = CUS, 11 (1976) 2, str. 123-131.

KUŠAR S., Filozofija o Bogu, KS, Zagreb, 2001.

KUŠAR S., Pojam vjere u Kantovoj filozofiji religije, u: Prolegomena, Časopis za filozofiju, 13 (2014) 1, str. 59-84.

KUŠAR S., Spoznaja Boga u filozofiji religije. B. Welte i božanski Bog, Biblioteka Filozofska istraživanja, Zagreb, 1996.

KUŠAR S., Tragovi transcendentnoga (I. dio). Pitanje o smislu i problem transcendencije, u: Obnovljeni život, 49 (1994) 3/4, str. 305-319.

LASIĆ H., Fenomenologija i filozofija religije, Biblioteka Filozofski niz, Zagreb, 2012.

LEIBNIZ G. W., In der Vernunft begründete Prinzipien der Natur und Gnade, u: LEIBNIZ G. W., Philosophische Schriften, prev. Holz H., sv. I., Kleine Schriften zur Metaphysik, Darmstadt, 1965.

LEIBNIZ G. W., Philosophische Schriften, prev. Holz H., sv. I., Kleine Schriften zur Metaphysik, Darmstadt, 1965.

LEIBNIZ G.W.F., Teodiceja - ogledi o dobroti Božjoj, slobodi čovjekovoj i podrijetlu zla, Demetra, Zagreb, 2012.

LIEBRUCKS B., Sprache und Bewußtsein, sv. 1, Akademische Verlagsgesellschaft, Frankfurt a. M., 1964.

LUCAS R., Antropološki status, u: MRŠIĆ V. A., Status ljudskog embrija, Centar za bioetiku - FTI, Zagreb, 2001., str. 67.-99.

MALOVIĆ N., Ima li nade u današnjoj filozofiji?, u: Riječki teološki časopis, 16 (2008) 1, str. 65-80.

MANSFELD J., Die Vorsokratiker. Auswahl der Fragmente, Übersetzung und Erläuterungen, Reclam Universal-Bibliothek, Stuttgart, 1983.

MARITAIN J., Tri reformatora, prev. Kovačević M., Laus, Split, 1995.

MARX K., Kapital, BIGZ, Beograd, 1979.

METZGER A., Phänomenologie und Metaphysik, Neske, Pfullingen, 1966. 
MIETH D., Meister Eckhart als spirituelles Vorbild und theologische Herausforderungen, u: Meister Eckhart und Bernhard Welte. Meister Eckhart als Inspirationsquelle für Bernhard Welte und für die Gegenwart, LIT Verlag, Berlin, 2015., str. 103-118.

MORO D., Crkva i crkvenost danas, u: BS, 69 (1999) 1, str. 91-106.

MURRAY J. C., Das Gottesproblem gestern und heute, Herder Verlag, Freiburg i.Br., 1965.

NIETZSCHE F., Morgenröte. Gedanken über die moralischen Vorurteile, hg. von Borken T., Henricus, München, 2019.

NIKIĆ M., Psihologija straha, u: Strah - naš životni pratilac, ur. Pozaić V., FTI - Centar za bioetiku, Zagreb, 1995.

PAVIĆ Ž., Egzistencijalne pretpostavke mogućnosti istraživanja religijskog načina bitka, u: FI, 9 (1989) 1, str. 64.

PEŠIĆ B., Uz temu Filozofija slobode - izabrani problemi, u: Filozofska istraživanja, 41 (2021) 1, str. 3-4.

PETZ B., Psihologijski rječnik, Prosvjeta, Zagreb, 1992.

PIEPER J., Über die Hoffnung, Kösel Verlag, München, 1949., str. 95.

PLANINIĆ J., Problem zla u svijetu, u: Obnovljeni život, 66 (2011) 3, str. 343-359.

PLATON, Fedar u: Ijon, Gozba, Fedar, prev. Đurić M. N., BIGZ, Beograd, 1985.

POPPER K., Logik der Forschung, Mohr Siebeck Verlag, Tübingen, 2005.

RADIĆ S., Ontološka dimenzija (moralnoga) čina u svjetlu grijeha i krivnje, u: Diacovensia, 27 (2019) 2, str. 224.

RATZINGER J., O relativizmu $i$ vrjednotama, prev. Ivanda I., Verbum, Zagreb, 2009., str. 90.

RENSON R., Fair play: porijeklo pojma $i$ njegovo značenje u sportu $i$ društvu, u: Kinesiology 41 (2009) 1, str. 5-18.

RICOER P., Interpretation. Der Versuch über Freud, Suhrkamp Verlag, Frankfurt a. M., 1969.

ROESNER M., Logik des Ursprungs. Vernunft und Offenbarung bei Meister Eckhart, Karl Alber Verlag, Freiburg, 2017.

ROESNER M., Selbstenäußerung und Selbstverleugnung bei Mesiter Eckhart unter besonderer Berücksichtigung seines lateinschen Schriftwerks, u: Meister Eckhart und 
Bernhard Welte. Meister Eckhart als Inspirationsquelle für Bernhard Welte und für die Gegenwart, LIT Verlag, Berlin, 2015., str. 119-140.

ROSENZWEIG F., Der Stern der Erlösung, hg. von Albert Raffelt, Universitätsbibliothek, Freiburg, 2002., str. 485.

RÜTSCHE J., Freud in der französischen Philosophie, u: Philosophische Jahrbuch, 78 (1971), 401-422.

SARTORY T., Braucht der Glaube 'Religion'?, u: HÖRGL C. i RAUH F., Grenzfragen des Glaubens. Theologische Grundfragen als Grenzprobleme, Zürich - Köln, 1967., str. 453-476.

SARTRE J.-P., Ist der Existentialismus ein Humanismus, u: SATRE Jean-Paul, Drei Essays. Ullstein Materialen, Frankfurt - Berlin - Wien, 1983., str. 206.

SARTRE J.-P., L'essere e il nulla, Mondadori, Il Saggiatore, Milano, 1958.

SCHILLEBEECKX E., Glaubensinterpretation. Beiträge zu einer hermeneutischen und kritischen Theologie, Mainz, 1971.

SHEENAN T., Dasein, $u$ : A Companion to Heidegger, ur. Dreyfus L. H. i Wrathall M. A., Blackwell Publishing Ltd, 2005., str. 532.

SKLEDAR N., Filozofija i religija, u: FI, 5 (1989) 1, str. 267-275.

SUTLIĆ V., Kako čitati Heideggera - Uvod u problematsku razinu Sein und Zeit-a i okolnih spisa, August Cesarec, Zagreb, 1984., str. 331.

ŠEGEDIN P., Svjetovanje svijeta (Bitak i vrijeme, §§14-24, 69-71), Bitak i vrijeme. Interpertacije, Zbornik radova, BARBARIĆ D., ur., Matica hrvatska, Zagreb, 2016., str. 1368.

ŠEVO I., Vizija svijeta u filozofiji Meister Eckharta, u: HUM, časopis Filozofskog fakulteta Sveučilišta u Mostaru, 11 (2016) 16, str. 143-162.

TIĆAC I., GUŠIĆ A., Uloga savjesti u etičkom prosuđivanju i djelovanju, u: Acta Iadertina, 4 (2007) 3-11, str. 9.

TILLICH P., Morality\&Beyond, Westminster John Knox Press, Kentucky, 1963.

TILLICH P., Religionsphilosophie, u: Gesammelte Werke, sv. 1, ur. Albrecht R., Stuttgart, 1959 .

TOLVAJČIĆ D., Suvremena analitička filozofija religije. Glavni pravci i autori, Katolički bogoslovni fakultet u Zagrebu, Zagreb, 2016. 
TUDOR M., Bog filozofa - Bog Abrahama, Izaka i Jakova u mislima Blaisea Pascala, u: Nova prisutnost 5 (2007) 2, str. 199-210.

ULRICH F., Atheismus und Menschwerdung, Johannes Verlag, Freiburg-Basel-Wien, 1975.

UZELAC M., Fenomenologija, Veris, Novi Sad, 2009.

VEREŠ T., Značajna »Filozofija religije«, u: CUS, 4 (1979) 8, str. 348-357.

WELTE B., Das Licht des Nichts. Von der Möglichkeit neuer religiöser Erfahrung, hg. von Zaborowski H., Butzon\&Bercker, Kevelaer, 2015, str. 94.

WELTE B., Das Licht des Nichts. Von der Möglichkeit neuer religiöser Erfahrung, hg. Zaborowski H., Topos, Kevelaer, 2015., str. 94.

WELTE B., Dasein als Hoffnung und Angst (1982.), u: Bernhard Welte, Gesammelte Schriften I/1 Person, Herder, Freiburg-Basel-Wien, 2006., str. 228-251.

WELTE B., Die philosophische Gotteserkenntnis und die Möglichkeit des Atheismus, u: Zeit und Geheimnis, Herder Verlag, 1989.

WELTE B., Die Würde des Menschen und die Religion, ur. Zaborowski H., Butzon und Bercker Verlag, Regensburg, 2017.

WELTE B., Die Würde des Menschen und die Religion. Anfrage an die Kirche in unserer Gesellschaft, Knecht, Frankfurt a. M., 1977.

WELTE B., Filozofija religije, prev. Kušar S., Matica hrvatska, Zagreb, 2016.

WELTE B., Filozofija religije, prev. Kušar S., Matica hrvatska, Zagreb, 2016., str. 258.

WELTE B., Gesammelte Schriften II/1: Denken in Begegnung mit den Denkern I: Meister Eckhart - Thomas von Aquin - Bonaventura, Herder, Freiburg, 2007.

WELTE B., Gesammelte Schriften III/3 Zur Frage nach Gott, ur. Zaborowski H., Herder Verlag, Freiburg, 2008.

WELTE B., Gesammelte Schriften Person I/1, hg. von Bohlen S., Herder, Freiburg-BaselWien, 2006., str. 288.

WELTE B., Gesammelte Schriften Person I/l, hg. von Stephanie Bohlen, Herder, FreiburgBasel-Wien, 2006., str. 288.

WELTE B., Meister Eckhart-Gedanken zu seinen Gedanken, Herder, Freiburg, 1992.

WELTE B., Über das Böse. Eine tomistiche Untersuchung, Herder, Freiburg i. Br., 1986. 
WITTGENSTEIN L., A lecture on Ethics, u: Philosophical Review, 74 (1965) 1, str. 3-13.

WITTGENSTEIN L., Tractatus logico-philosophicus s uvodom Bertranda Russela, prev. Petrović G., Veselin Masleša - Svjetlost, Sarajevo, 1987.

WITTGENSTEIN L., Tractatus logico-philosophicus: Logisch-philosophische Abhandlung, Suhrkamp Verlag, Berlin, 1963.

ZAHAVI D., Husserls Phänomenologie, prev. Obsieger B., Mohr Siebeck, Tübingen, 2008.

ZIMMERMANN S., Filozofija i religija I-II, Zbor duh. mladeži zagrebačke, Zagreb, 1937. 


\section{Životopis}

Suzana Maslać rođena je 15. siječnja 1988. godine. Živi u Bizovcu. Na Katoličkom bogoslovnom fakultetu u Đakovu 2007. godine upisala je filozofsko-teološki petogodišnji studij. Pod vodstvom mentora izv. prof. dr. sc. Stjepana Radića obranila je 2012. godine diplomski rad pod naslovom Eksplikacija fenomenologije religije Martina Heideggera u izabranim djelima. Od 2013. do 2015/2016. godine boravi na Sveučilištu u Beču (Universität Wien), pri Institutu za filozofiju, kao stipendist Pastoralnog Foruma (Pastorales Forum. Förderung der Kirchen in Ost (Mittel) Europa) gdje započinje poslijediplomski doktorski studij filozofije. Godine 2016. upisuje Filozofski fakultet u Zagrebu, poslijediplomski doktorski studij iz filozofije. Službena je tema doktorske disertacije Osoba i vjera u fenomenologiji religije Bernharda Weltea.

Od ožujka 2015. godine zaposlena je kao asistentica pri katedri filozofije Katoličkog bogoslovnog fakulteta u Đakovu Sveučilišta Josipa Jurja Strossmayera u Osijeku gdje sudjeluje u izvođenju nastave iz kolegija Ontologija i Filozofska antropologija te seminara i izbornih kolegija.

\section{Aktivna sudjelovanja na simpozijima/znanstvenim skupovima}

Svibanj 2011. sudjeluje na prvom studentskom filozofskom simpoziju u Osijeku s temom Etika vrline kod Alasdaira MacIntyrea

Svibanj 2012. sudjeluje na drugom studentskom filozofskom simpoziju u Osijeku s temom Filozofska analiza filma The Truman Show

13. - 20. svibnja 2012. stipendistica Matice hrvatske za sudjelovanje u Filozofskoj školi Matice hrvatske održane u Orebiću pod nazivom Martin Heidegger - Sein und Zeit

Svibanj 2013. sudjeluje na trećem studentskom filozofskom simpoziju u Osijeku s temom Odnos filozofije prema religiji i znanosti u mišljenju Nikole Skledara

9. ožujka 2016. sudjeluje na Znanstvenom kolokviju u Đakovu prigodom 420. obljetnice rođenja R. Descartesa s temom Meditacije o prvoj filozofiji - René Descartes

19. i 20. listopada 2017. sudjeluje na Znanstvenom skupu u Osijeku (Filozofski fakultet) Reformacija u Europi i njezini odjeci: povodom 500. obljetnice Lutherovih teza s temom Pročišćenje religije u Hegela - prema njegovim predavanjima o Filozofiji religije 
13. - 15. prosinca 2018. sudjeluje na Znanstvenom skupu Filozofija i stvaralaštvo u Zagrebu s temom Stvaralaštvo kroz prizmu Welteove filozofije religije 


\section{Bibliografija}

Stručni članci

1. Maslać, Suzana, Meditacije o prvoj filozofiji - René Descartes, u: Diacovensia, 24 (2016) 3, Đakovo, str. 485-496.

2. Maslać, Suzana, Pročišćenje religije u Hegela - prema njegovim predavanjima o Filozofiji religije, u: Zbornik radova Reformacija u Europi i njezini odjeci: povodom 500. obljetnice Lutherovih teza, Osijek, 2019., str. 351-367.

Izvorni znanstveni članak

1. Maslać, Suzana, Molitva šutnje, govora i kulta kao načini izvršenja religije u filozofiji Bernharda Weltea. Prikaz temeljnih aspekata, u: Diacovensia, 28 (2020) 4, Đakovo, str. 465-479.

Sažetak

1. Maslać, Suzana, Stvaralaštvo kroz prizmu Welteove filozofije religije, u: Filozofija $i$ stvaralaštvo, Godišnji simpozij Hrvatskog filozofskog društva Zagreb, 13. - 15. prosinca 2018., knjižica sažetaka, Hrvatsko filozofsko društvo i Učiteljski fakultet Zagreb, 2018., str. 54.

Recenzija

1. Maslać, Suzana, Bernhard Welte. Filozofija religije, prev. Kušar S., u: Diacovensia, 25 (2017) 3, Đakovo, 2017., str. 495-498.

\section{Članstva}

1. Od 2018. godine članica je Hrvatskog filozofskog društva. 